Junana: Game B starts with education

\title{
Junana: Game B Nation [Book 2]
}

Bruce Caron

Published on: Jan 03, 2021

DOI: $10.21428 / \mathrm{d} 577702 \mathrm{e} .86 \mathrm{c} 6 \mathrm{f} 732$

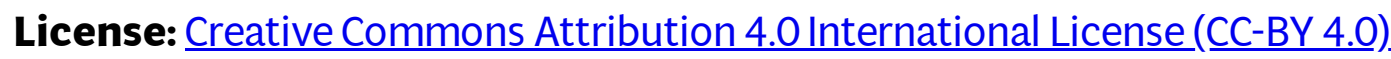




\section{ONE}

Nick's phone alarm went off with its lilting calliope rendition of "The Bear Went Over the Mountain." Annoying enough to wake a corpse. Megan could feel him spooning her on their double futon. It was early for a Friday. The dawn was half an hour away. Not even the scrub jays were up. He reached back and punched the phone. His arm encircled her again but his breathing picked up.

"Gotta run, Meggie. Quite a day ahead," he said.

For Nicolas Landreu, the day would include gathering the Santa Barbara High surf club and taking a Noël van up to Gaviota where they would meet the boat to go to the Ranch. The web had predicted a great south swell. That evening he and some of his former high school buddies would lift a few beers downtown. It was Fiesta, and they had their traditions. He would drop by Megan's grange after that. Today's concert was an old-school rock-and-roll band from an Atascadero grange.

Megan Doolan had a full day at the grange ahead of her: the council was meeting in the morning to approve additions to their childcare center. She had interviews for the computer system sysadmin position in the afternoon. All the granges were being instructed to level up the badge requirements for their top information tech staff and to stock a whole lot more CPU capacity. Last week, a GrangeMinder stopped off to check on their progress. The Grange chip forge in Ventura was already at capacity, which meant a month delay. Megan needed to find a couple hours to grade some grange management badge tests online, and had a noon virtual meeting at her Guild's craft hall in Castalia. She had volunteered to chaperon teens at that evening's rock concert. She had faint hopes to catch a Master Lu body work class at some point.

"Got a surprise last night," Nick said into her ear. The previous evening, Megan had dozed off while he was still up on the Game in the living room.

"Hmmmmm," she answered.

"All right. Coffee first. Then surprise." He gave her left breast a friendly squeeze and kissed her gently on the nape of her neck. She was just starting to think about being awake then but he was gone. She settled into her pillow. Then he was back. 
"Here you go, sleepy." He waved the mug of coffee in front of her face. She took a deep breath and opened up her eyes. The dawn was rolling up the darkness. A titmouse sang in the laurel bush near their window.

She sat up and took the mug in both hands. He was kneeling next to the futon looking down at her.

"Go away. What kind of a man slave are you? First you tease me, then you bring caffeine, then you stare at my morning hair." She took a long sip and closed her eyes.

"I’m a Sixer!"

She opened her eyes. "No shit!"

"It happened last night. I logged into Castalia and everything!"

"Sweetie, that's wonderful!" She leaned forward and they kissed. He tasted of toothpaste. She cut it short, remembering she hadn't brushed yet. She tousled his hair. "Sixer looks good on you!"

"You really have to spend more time on the Game," he said. They had always leveled up about the same time.

"Soon as they invent forty-eight hour days..." She hadn't spent any serious Game time in months.

"You're rotating out of being a grange manager next year. Then you can focus back on the Game and you'll be a Sixer pronto."

Megan had won the lottery on this job three years back. She applied on her experience as the manager of the Westwood GameTown. Megan also had considerable Starshine from her status as a Level Five player in the Game, and from the badges she had earned on community leadership and organizational management.

She and Nick moved up from Santa Monica to stay in Scratchy's guest house on Lotta Vista Lane. Scratchy was still living with Betsy in Sao Do, Vietnam. Nick had gone to high school in Santa Barbara, and his former English teacher found him a short-term position teaching dance at the school. This year he won a prize from his gumi that gave him the jikan for a badge class at a local college.

Grange 829 in Santa Barbara had been a Dodge auto dealership until 2009. It stood vacant for years before a mura purchased it and began to transform its five acres and 
a hundred-thousand square feet of showrooms, parts departments, sales offices, and auto repair shops-with parking for four-hundred shiny new Dodge and Chrysler sedans, pickups, and SUVs-into a full grange.

Managing a grange took a lot of hand-holding, a knack for improvisation, a solid background in practical economics, and the patience of a zen master. All of these Megan had, and more.

"Don't let it go to your head, young man. You may be a Sixer now, but I knew you when you just earned your shoes!"

"I’ve got to run. Let's celebrate tonight."

"Tonight." She took another sip of coffee and smiled at him. Nick stood up and did some mock dance steps toward the bathroom. She watched him shuck his tee shirt as he left the room. Becoming a Sixer is a big deal, she figured, almost as big as becoming a Meister. Sixers are one-in-a-thousand players. They can gather in Castalia, although they can't enter the main castle. And they can become Spimecops and can work on a whole level of badges not available to Fivers. Some part of her was sending off its own alarm. She reached down inside and quieted it.

\section{$\S \S \S$}

His amma woke Joseph in the already warming, Mysore City darkness.

“Do not wake your father," she whispered. "Appa has much to do today."

Until Joseph was nine years of age, Joseph's father was also awakened early, but then this became Joseph's chore; a signal moment of his coming of value as the son for Tom and Son Chappals, Mysore's best sandal makers, what Joseph's grandfather, also Tom, told his son each morning. Joseph's twin younger sisters, Mary and Miriam, lay tangled on their mat in a corner as he sipped a bit of milk and blinked away sleep. A clean shirt and he was outside. Joseph carried the large burlap sack, empty and light, with his mother's kiss still on his cheek> A tiffin box with a rice ball, and a plastic bottle of water were snug in a small cloth pack over his shoulder.

The path to the great curve in the Kozhikode highway took Joseph directly through one of the older residential compounds, where white bungalows with broad verandas were covered in bougainvillea and jasmine, surrounded by carefully tended lawns, and 
protected by brick walls topped with glass shards. Many of the estates had automobiles parked for the night, and some had guards with turbans who were paid to keep people like Joseph from even glancing in their direction.

Joseph had no need to glance anywhere but in front of his feet. At this time of night, with the sun still an hour from rising, he was mindful that he and his father had once encountered a cobra sliding across this very road, silent on the black tarmac, and then coiled and ready for battle when Joseph, mostly asleep, stepped on its tail in the darkness. Tom yanked the boy out of danger and they sprinted away into the dark before stopping to see the snake lay back down on the road and slip silently into the gutter.

"Maybe it will crawl up their toilet," Tom said looking at the mansion behind the wall. "Strange it did not bite you."

“Toy let?” Joseph asked.

"Keep your eyes on your path. You might have stepped right on that snake's head." Tom lightly cuffed Joseph on the crown of the head with the back of his hand to make this point more directly. And for a good mile, he kept glancing back and talking to himself.

The Kozhikode Highway was a busy two lane asphalt thoroughfare, with lorries and buses speeding their way through Karnataka and the forests of the Western Ghats, down to the coast of Kerala. For many years Joseph's father Tom had collected tire fragments-strips of unraveled tread worn smooth from miles of heat and dusty roadways, worked until their glue gave out and then ripped from the tires on one final curve, sometimes with a firecracker blowout that sent the lorry careening into the ditch. These fragments were added to the pile of rubber scraps in the locked godown shed beside their family's hut, to be cut into the soles of chappals. He also picked up any plastic or metal or scrap of paper he could find. Everything had its own value.

Now it was Joseph's job to hunt for rubber in the first glimmers of the dawn, before the others collected the previous night's bounty. The pile of rubber in the godown was never to be less than one gaz tall, enough for some weeks ahead, as tall as Joseph at nine years. Today, Joseph was very lucky. A lorry had shed almost an entire tread on the same corner of the great highway where his path intersected this. Joseph cut this into three large pieces and filled his sack, eager to get back home. For today was also Joseph's birthday. 
On the far side of the residential colony was a government middle school surrounded by a high wall. Some time before, but not so long ago, because young Joseph remembered what it was like before this, they installed several public computers into the wall facing out to the street. Protected by metal covers overnight, these were opened for children at daybreak. For months now, on his way back to the hut, Joseph would stand in line with the others to wait for his ten minutes with the screen before racing home.

There were games with rockets and lasers, and puzzles with numbers and letters. His amma had taught him some alphabet, what she could remember, but not all of it. He could roll the ball and move the marker to aim and shoot. And there was Junana, a voice that called him by name and asked him so many questions, which he must answer before he could aim and shoot.

Today, when his turn came and he told the computer his name and put his thumb on the square, instead of the screen with his scores, there was a door with a large brass handle. He moved the arrow to this and pressed the button.

“Look!” a girl behind him in line said. "He's going through the door. He's going to play the Game."

"Impossible! He’s too young," a boy's voice said, "He can't even type."

"The Game knows when to invite you," the girl replied. "Don't be silly. Just because you haven't been called yet."

Joseph had seen this door before, with older boys who no longer solved the same puzzles, but rather spent their time talking and typing until the computer told them to let the next child have a turn.

"Be quiet!" Joseph said. The door opened, revealing the image of a room with a proper ceiling and a smooth painted concrete floor, and with a real bed and mattress, a desk with a laptop computer, and a cricket bat leaning on the wall covered with recent movie posters. There was a boy, about Joseph's age, dressed in a smart shirt of blue and red stripes, tan trousers with a great crease, but also barefoot. He turned from his chair at the desk and stood.

"I am Amitabh, your guide," he said. "We are going to be such good friends!" The boy smiled and tossed his head in a great laugh. Amitabh's black hair was bright with lotion. He brought his hands in front of him and pressed them together in a greeting. 
"His guide is named 'Amitabh'," the girl's voice behind Joseph said. "Go ahead and speak with him."

Joseph leaned closer to the screen. "I am Joseph," he said.

"Yes, and today is your birthday," said Amitabh. "Do you want to play a new game? It will be much harder than the ones you've played before."

"I am not afraid," Joseph said.

"That is very good. Let me show you the first Level. There are seven palaces, each with its own puzzle. You must solve every puzzle before you can move on to Level Two."

“Ooh! He's got palaces!" the girl's voice rang out behind Joseph. His conversation with Amitabh seemed to be over in a few seconds. Suddenly his guide was bowing and the girl behind Joseph elbowed him to the side. As he stepped away, Joseph saw the screen change to the scene of an arcade of brightly lit shops, and a girl in a blue salwar cameez bowed in greeting.

“Hello, Meena," the guide spoke. "Welcome back. We were just about to..." Joseph stepped back and his foot landed on that of a large boy who yelped and pushed him aside.

"Filthy Dalit, watch where you step!"

Joseph, staggered sideways and raised his hand to protect his face. No blow came this time. He mumbled an apology and quickly turned to escape. The line of children was focused on the computer. None of them would chase him and lose their place. So Joseph shouldered his bag and walked away thinking only of Amitabh and the next time they would meet.

\section{$\S \S \S$}

Dwayne and Sheryl insisted on blindfolding Samantha. In the dewy Santa Barbara dawn, they lead her by hand out onto the estate's broad curving drive .

“OK, honey, you can look,” Sheryl said.

Samantha removed the scarf. 
The new cherry-red BMW three-series convertible had its top down. Its hood sported an enormous gold satin ribbon and bow. Leather seats gleamed like honey-butter in the early morning sunlight. Samantha knew they would get her a car for her sixteenth, but she had made it perfectly clear she was going petroleum-free. Electric or hydrogen only.

Five years ago her big brother Greg had gotten a three series for his sixteenth birthday. He took it with him when he went off to Pepperdyne. So now this was some kind of family tradition. Last month, Samantha found a big, glossy BMW brochure tucked under her laptop. She, in turn, had printed out a list of her top three cars and put this on the refrigerator door.

"This...this is my car?" she said. "This?"

"It gets wonderful mileage," her mom said.

"Hop in and we'll give it a spin." Her dad jiggled the keys and tossed them to her. They bounced off her t-shirt onto the driveway.

"The dealer can take it back," Samantha offered. Her dad knew all the top car dealers in Santa Barbara. "You can get your money back."

“We don't want our money back," her mom's tone shifted. "We want you to be happy.”

"I suppose I could trade it in." She picked up the keys and walked around the car.

"It's a brand new car, Sweet Pea," her dad said. "You always liked red." He put his arm around her mom, who was slowly shaking her head.

Samantha fingered the wide satin bow and turned to them. "I want you to know I appreciate the effort you went through to get me this. I am trying to do the right action, the mindful action, with my choice of personal transportation. So, I can't use this car..."

"You can go to your room and stay there while Dwayne returns this beautiful, thoughtful gift. Don't imagine we'll be taking you down to get your driver's license any time soon. You can ride your bicycle until you go away to college." Her mom pointed at the house. "Go on, young lady!" 


\section{TWO}

The entire Castalia sysadmin team had been alerted that something would happen midday. Scratchy's Rodent Army was an array of software hacks built to test the real-time resilience of the Castalia code and the mettle of its admin team. His Rodents would attack individual services to test their weaknesses. Any attack that brought down the service beyond an initial response and immediate repair signaled an all-night code sprint. The goal was to be ready for all outside hacks. The sysadmins would know exactly what to do when the fan and the shit did their dance.

Scratchy grinned. They were not expecting an attack on the mesh computer itself. Nobody had ever successfully attacked the mesh, not until today. Scratchy keyed the command and unleashed his new StormVermin code on the Castalia software stack.

His goal, as Scratchy told them often enough, was to make their software superversatile. Superversatility meant the code was not simply resilient, but designed to be broken and to grow stronger every time it fails. Like human bones and evolutionary schemas, superversatile systems thrive when individual members are stressed. Whole species will become extinct in the process, limbs will get crushed and snapped, but speciation and osseous tissue just gets stronger.

\section{$\S \S \S$}

Lieutenant Colonel Nancy Rankin responded to her phone's urgent chime. The time read one hundred hours. The text was short: "Castalia hacked." She keyed a response: "Full report. My office. Seven hundred hours." It had been several years since the NSA helped hack the Junana social network and its Game. Since then, any attempt at even probing the site risked a catastrophic counter measure from the rogue AI who called herself Michelle. Michelle Valentine Smith had serially damaged the cyber-ops capabilities of the Iranians, the Ukrainians, the Chinese, and the North Koreans. Repair from her counterattacks took months. So who would she target now? 


\section{$\S \S \S$}

Scratchy's cellphone rang. He smiled as he answered it. He looked at the time on his laptop. StormVermin had been at work for more than ten minutes.

"That was rude," Desi said. "I was talking to a crowd in Castalia and the scene froze. Then it crashed the client. What are you doing to your team today?"

“Total chaos," Scratchy said. "I attacked the mesh directly."

"You can do that?"

"Who better?" Scratchy had invented the original Game mesh. His design emerged as a class four cellular automaton. Each CPU contributed to the whole, while only contacting its neighbors. On top of this global structure, Scratchy programmed the computational layers, and included defenses against attacks, such as the one he just made. Or, more precisely, except for the one he just made.

\section{$\S \S \S$}

On the low bedside table next to his futon, Simon Bishop's laptop woke up from sleep mode. An avatar appeared on the screen. "Simon. Wake up. Something is wrong. Very, very wrong. Wake up!"

Simon rolled on his side and opened his eyes. "Michelle?"

The room was still dark. "What's wrong?" He sat up and pulled his computer over to his lap.

"Castalia is down." Michelle paced restlessly back and forth across the screen.

"OK. You know it's Friday here. What time is it in Vietnam?"

"Just after noon on Saturday."

Simon let out a long sigh. Scratchy must be at it again. Michael O’Hara had a habit of stressing the code for Castalia. Simon didn't understand why he felt it necessary to do so, but Simon trusted it mattered enough to panic the planet now and then, and always at noon on a Saturday. 
"Have you checked in with Scratchy?"

“You know I agreed to keep away from Castalia."

Michelle's willingness to make and keep agreements was an unexpected blessing. Simon was careful to support this behavior. "We'll give it another ten minutes. If Castalia is not back up, I'll ping Sao Do."

"Something is different this time. It's like the entire Castalia code has just vanished."

“Ten more minutes. I'm sure everything will be fine.”

Michelle nodded and disappeared. Simon's computer went back to sleep. Simon was not so lucky.

\section{$\S \S \S$}

Desi said, "Mercy! Tiny must be in a state."

"I'm counting on Tiny to pull his team through this. We are going superversatile on this bitch," said Scratchy.

“So you've been telling me. Don't you think it's overkill?”

"We built the Game to make this new, what do you call it? Epistem...off?..."

“Episteme. It's a new way of knowing. It's the only way we could grow Game B logics across the planet to see what emerged. We do it through templates, so people grow their collective intelligence."

“Well, we seeded this to a couple billion Gamers. Now that's what I call superversatile!"

"You just lost me.”

"We could have created a small cadre of experts, like a new fucking invisible college. But that would eventually break down like the academy did in the last decade. We could have broadcast authoritative messages we pulled from our ass, like all politics up until today. Or backed a strong-man with military might. Instead we just opened the eyes of kids to a new level of shared knowing..." 
“Really, Mikey, do you know how many people are using Castalia at any moment?”

"That's the whole point." Scratchy keyed in some code and pressed enter. "I called off StormVermin and inserted the anti-virus code to heal the mesh. Happy now? Let's see how fast they can reboot from the latest backup. The Game mesh will fail too, at some point. We need to have the next best thing up and ready in time."

“The next best thing? Why that's me dear boy. You know I'm always up and ready for you."

$\S \S \S$

Samantha settled back on her beach towel, her weight shifted the warm sand, which cradled her slender form. She pulled her sunglasses down from her forehead against the glare. Her friends had arranged themselves around her. Their chatter jumped about like vireos in a hedge. Between text messages they offered their takes on last night's gossip from Hollywood and Montecito, updates from friends on travel, and WTF clickbait off the web. Samantha swallowed her disappointment. Out of a list of more than a hundred, only a handful of the invitees had shown up for her birthday party. Sure, Sam had missed a bunch of parties and weekend gatherings herself over the past year. Once the Game gets you, there's just so much to learn, and the time runs away like one of the impalas out on the Serengeti of her Gamescape.

Apart from lacrosse, which she really liked, and the regular trips abroad her parents dragged her along on, she was spending a lot more time in her bedroom on her computer where the pull of a monster Query tugged her mind through a labyrinth of knowledge that somehow she knew she needed right now. Or sooner. Somehow, every Query ended up in triumph and laughter, although she sometimes found that Moses, her guide, would pick new queries that covered some of the same templates, until she could jump through the whole strand from capstone to seed template and back, like hopping on stones in a stream.

Level Two was a total biotch but she bested it too. Since she earned her Game shoes, Samantha had met dozens of senior Gamers in cafes and coffee shops around Santa Barbara. Mostly she listened and made notes on what to read next and connected with them on Junana, the old-time social network that came with the Game. 
Junana was unique. Not just a place to share updates, it had a 3D interface that included detailed walking maps of lots of cities and parks. And with its language translation software, Samantha could interact with peeps across the planet on scenes that ranged from newska dance floors to university quadrangles. There was even a digital Burning Guy event every spring, but you have to really be eighteen to get in.

Some of her new Game friends were already Fourveys or higher. None of those were coming to her party today. The Doral Casino was not a "blue label" operation, they explained. Besides, something was planned for this afternoon. Something big, secret, possibly illegal, and certifiably fun. More fun than her sixteenth birthday was shaping up to be.

Samantha tried to get her parents to move her party to the Upton Hotel, a fully blue label operation. Blue label meant that their food came from known sources all the way back to the corn they feed the chickens. "Where does the Casino get its food?" she asked.

"Where everybody gets their food, dear," her mom replied, "Only it's better. It's more expensive."

Dwayne and Sheryl were already partying over at the Casino, which sat just above the beach. Dwayne would be watching a pre-season football game on the big screen and drinking Manhattans. Sheryl was probably poolside with her own covey of friends and a series of martinis. At six o'clock Samantha's "real party" would start on the terrace. Dinner and a cake and then live music in the ballroom. She tried so hard to talk them into getting a DJ up from LA. Instead they paid for the services of one of their favorite bands from way back in the '90s. The band's one hit, something that sounded somewhat like Michael Jackson, was still Sheryl's party favorite. Dwayne was flying the whole band in from Chicago for a one day gig. Sheryl had invited all their local crowd to help celebrate "Darling Samantha Mooney's Sweet Sixteen."

Samantha and her friends had just finished off an hour of ultimate frisbee on the beach with a swim in the ocean. The sun warmed her. Drying sea salt chafed slightly at the elastic of her powder blue bikini bottom. Samantha realized she had played the morning's drama completely wrong. Better to have accepted the Beemer and traded this in later for a Noël. Later means after she talked Dwayne into letting her join the grange. 
Everybody who earned their shoes in the Game these days was joining a grange. Locally there were several to choose from. These occupied formerly abandoned commercial and industrial sites. They could be recognized by a lack of signage, by the photovoltaics on their roofs, greenhouses where parking lots once stood, and by the commotion of hundreds of members at work or at play. Unlike the last century's social clubs, the Lions, Elks, Moose, and Odd Fellows, whose vestigial halls were mainly taverns and card parlors, granges rang with machinery and sang with music and theater. The Guild of Grange Managers put out a guide for prospective members. Samantha puzzled through this aided by some focused free-for-all time in the Game.

Badges and roles were easy. Badges signaled what you know. You apply this knowledge by accepting roles at a grange or its factories. Granges were maker and hacker spaces, and they also made real goods for the regional Game B economy. Game B was anchored in a broad selection of templates. In combination, these formed the launching pad for an economy distinctly different from the surrounding, Game A, marketplace. Everyone who joined a grange was required to puzzle through these templates from capstone to wellspring, until they could dive into any conversation and drive this forward. At that point a new repertoire of practices made perfect sense. Like badges. Badges were honored across the planet. So you could walk into a grange in India or Sweden with the right badge, find an open role and get to work.

The social groups were also easy. Gamers create a "mura," a kind of village community. This group incorporates the grange. Each member buys a share and pays dues. The mura can have nearly a couple thousand members. The mura is then divided into twelve "gumis". The gumi is the working unit for maintaining the grange. All the volunteer roles are distributed monthly. Gumis donate member time to the grange. Each gumi is finally divided into twelve dachis. A dachi is a small group, only ten to twelve members. These work and play together, sharing and learning as friends. Having a dozen new friends left little time for outsiders. Even friends Samantha had known since grade school became almost strangers once they got into a grange. As long as Samantha was not a member of one, she would never really connect with other Gamers.

Samantha sat upright on her towel and looked around her. Madison, Sean, Brianna, and Logan had parents who were Dwayne's clients. Riley, Ethan, Helen, and Brandon were Montecito brats. You could find them hanging at the Casino and beach on any Sunday. Cameron was, well Cameron. Sweet, cute, eager to please, and-so her friends told her-hoping to get close with Samantha. Kylie was almost poor. Well, her father 
owned some fast-food franchises, but she lived in Goleta. She was overweight, continually on a diet, and probably bulimic. Everyone was on their phones, mumbling as they texted, headphones buzzing tunes into their ears. Wasting time on a sunny beach at low tide.

Time was the part of grange life that puzzled Samantha. Granges counted hours like these were diamonds. They banked them like doubloons. Somehow, most of the grange terms came out of Japan. Time was called "jikan."

Samantha's Game Queries had led her through the stoics, who were time fanatics, to the Fordists and modern efficiency theories. Jikan was a concept deeper than any time stream a Fordist might consider. Given that the richest man and the poorest might have the same life span, time was the ultimate leveler. In a cash economy the rich could trade their money for other people's time. With her family's billions, Samantha could spend her time exactly as she desired. Sure, there was school, but after that, Samantha's time was her own. When she gets to Level Four in the Game, school would be optional. Having time, spending time, and using time were not the same she read. Knowing the difference might take a lifetime.

Granges were keen on sharing daily chores to open up more individual time. The Restaurant Every Meal template meant that only a fraction of their members ever cooked or cleaned dishes on any week. Collective laundries, house cleaners, child and elderly care, and handiman services saved a lot more jikan in a year than members donated to their grange and gumis. Living in a grange was made easy so that its members had time to pursue difficult goals.

Funny, the goals she used to hold on to so strongly, goals her parents offered her as given and unassailable-marry rich, live fast, impress the right friends, ignore anything that might make you sad-had become small and mean in her mind. She watched a young boy intent on filling his bucket with wet sand. All the small kids on the beach had no idea of how the templates would soon interrupt their lives, how just one brand new idea with a solid purchase inside a truthful system can unhinge a entire life of wanting something or knowing something with a certainty that had no source.

In the Game, Samantha discovered the difference between being told what was true and being shown what made the most sense, with an invitation to test this sensemaking for herself. Her Game guide, Moses, once told her that the questions gamers asked were also capable of reshaping the templates of the Game. So a fourteen-year old with the right question might alter how the Game worked for the whole planet. 
This meant that the Game was using its players to make better sense of the world. Some gamers also found entire new templates, growing the scope of the Game as they played it. When she learned the template strand about the Infinite Game, everything clicked into place.

In the place of their discarded childhood desires, grangers now gathered up Shine. Shine combined two goals. One was the aggregation of accomplishments, mostly Game levels and skill badges. The other was more fluid and personal. This was the reflection of your social worth, counted by those around you who appreciate your service and attitude. Reputation came down to who you are, what you do, and how much dignity you allow to others. Samantha's Queries in this direction ran from the Upanisads to Doctorow. Shine quantified reputation in a manner and to a precise amount never before available. Shine and jikan were interlaced somehow, so that you could live modestly on the combination of them once you had acquired enough Shine. All of this was internal to a grange, and not available and nearly invisible to the outside.

There was still a way to earn and spend cash, of course. Not all services could be had for jikan. But here too, grange wages tended to be set at some reasonable amount, and were the same for everyone from the manager to the dog sitter. Cash was not the gasoline in the engine of this commons-based economy, it was simply the oil that greased its bearings. Samantha Queried through the Social Capital templates. Looking about her on this, her sweet sixteenth birthday, she felt a jolt as she realized how poor she was in this mode of wealth. Her next shock was the vision of what had appeared around the headland down the beach.

The mob was naked. They raced at the surf line, some of them kicking up water as they ran. Those in front were young and athletic, products of Pilates and CrossFit. Their numbers exploded around the cliff face like a herd of gazelles eager for a watering hole. Tits bouncing, dicks swinging, they laughed as they sprinted. And they kept coming. Must be hundreds, Samantha guessed.

"What the fuck?" Brandon stood. "Check this out!" he called. The others turned away from their phones. The front squadron of the streaking flash mob approached. Males jockeyed for position at the fore. Samantha took in their naked forms. Naked and in motion. The spectacle struck a hard note of arousal deep down below her navel, and she felt her breath quicken. This note was boosted by an overtone of abject joyfulness. She was simultaneously astonished and delighted. 
Alongside the alpha males Samantha recognized Elle, last year's head cheerleader at Laguna and a triathlete. Elle ran like an Amazon: blonde and lithe. Her arms pumped. Her pony tail bounced in rhythm with her stride. Elle lifted her chin and gave out a yell. Her mates echoed this. Behind this vanguard, hundreds more ran at their own pace. The rear of the mob was still emerging around the cliff. Make that thousands, Samantha realized. Of course, she figured, this massive frolick is the surprise event that kept her Gamer friends away from her party.

Along the beach, sunbathers stood and gawked. Most had their phones out to take videos. Some shucked their swimsuits and joined in. Others gathered their children close and glowered at the spectacle. Some parents tried to hide their children's eyes. The kids squirmed to look. Samantha turned to spy over to the Casino. Her dad was on the terrace with his buddies. They were crowded against the glass partition wall overlooking the beach, gesturing and gawking.

Samantha stood up. Unconsciously, her hands reached around for the string of her bikini top. Half of her group were already undressing. Giggling, Riley and Helen tore off their tops and wiggled out of their bottoms. Brandon and Ethan dropped their board shorts and raced each other to the water. Cameron looked expectantly over at Samantha. She was still focused on the Casino terrace. Her father glanced over in their direction. His smile bent into a frown.

"Shit," Samantha whispered, folding her arms in front of her. She was already in the dog house with Sheryl. If she had any chance to join the grange any time soon, she would need to tread lightly.

Brianna hesitated. "Cameron. You do it and I will too," she said.

"You start," he replied.

“O.K.," she pulled her bikini top off over her head. "You're next!”

Cameron grinned and dropped his Volcom board shorts to his ankles. He kicked them away and set off for the surf line. Brianna slid out of her bottom and followed. She jumped up on Cameron's back and he piggy-backed her into the middle of the running mob.

Madison, Logan, and Sean were videoing the scene on their phones, cracking jokes about the exposed anatomies.

"Look at the belly on that one," Logan said. "He probably hasn't seen his dick in years." 
"He's not missing much," Madison said. "Whoa, check out that one. Now we're talking!"

Behind Samantha, up on the road in front of the luxury hotel, three county patrol cars pulled up with a blare of sirens. The officers emerged and crowded the low stone wall that fronted the beach. They spoke urgently on their radios. Samantha grinned at their predicament. The entire flash mob was now visible. They spanned the whole beach. The front runners raced past the Casino, the rear guard, older, slower, and more portly, but no less joyful, had finally cleared the headland.

Kylie came and stood beside Samantha.

"Some of these women should think more carefully about getting naked," she said.

"Damn!"

Samantha had made the mistake of inviting Kylie to join them in Paris one Spring and in Kona the next Summer. Now Kylie was hanging around her like a lap dog, angling to get on the business jet again. Samantha glanced over at her. Kylie wore an oversized Banana Republic t-shirt over her one-piece.

"Do us all a favor and keep that t-shirt on," Samantha said. Kylie frowned and moved off.

Samantha lay back down. She rolled onto her front and cradled her head in her arms. Underneath the lilting chorus of their laughter she could hear the flash mob's collective footfalls on the damp tidal sand. They were like a train passing by, or life itself flowing on. Passing Samantha by, and flowing on without her. She wasn't about to cry. Not on her sixteenth birthday. Not in front of Kylie Simkins.

\section{THREE}

Samantha Mooney lay in her bed and watched the dawn light moving against the far wall. She slept with the windows open. Outside her window the birds in the oaks were 
jabbering. It was a big day ahead. She had few illusions that it would go her way. Her way was seldom the final chosen word.

Samantha reached for her laptop and pushed the power button. While it booted, she sat up and started her brainwave exercises: circling the left hand, right hand to the diagonals, and then switching, and adding in the finger motions, faster now, pay attention, don't skip anything, and breathe. She could see Jorge, beautiful Jorge, standing on the beach with his chiseled lats and bulging speedo, demonstrating just how it worked. Moses had let Jorge kiss her avatar when she had finished learning. Then he sulked for a week.

Samantha let her breath in and out with measured care, continuing for a full four minutes. Now she was ready for Moses, her guide. She clicked open the Game and watched the Level Three scene emerge.

Moses was not in his robes, but dressed in a dark suit coat and a white dress shirt with a yellow tie under a v-neck sweater. He was still barefoot. The scene morphed into a classroom, in fact a room that looked exactly like one of hers at Laguna Clara School. She put on her headset and microphone.

"I can't do a Query today," she said. "I'm off to the grange this morning. My dad will never let me join. Can we talk?"

"In my classroom, I do the talking, little miss," said Moses sternly.

“What's that about? Where's the savanna?" Level Two had been played out mainly across a swath of the Serengeti.

Since she was a toddler watching the National Geographic Channel, Samantha had been entranced by the plains of Africa, so huge and remote. When she got old enough to join the Junana social network, she had herself scanned and her avatar spent a lot of time wandering through the 3D Africa scenes. From Casablanca to Durban, a lot of the Continent had been mapped in the network's matrix, and whole parts were available to wander through. On her fourteenth birthday when Samantha first opened up the Game her Junana avatar found itself in a tented camp. Moses, her guide, was a Bantu prince.

Moses wore a simple kaftan-style white robe. "You would be Samantha! Such a beautiful name. I am Moses, I will be your guide in the Game." He stood next to a towering termite mound of red soil. In the background a herd of elephants sauntered across the grasslands. He was young and strong, with skin as lovely as a prune plum. 
Then he smiled and his hands raised in the universal Junana greeting. The way he did it reminded her of Will Smith. Only Moses was younger, darker, and had straighter teeth.

Today, Moses looked like he was trying out for the lead in Dead Poets' Society.

"Your school will be starting soon," he said.

"Reminders, I don't need."

"The summer reading list is substantial. And I think we can get through beginning calculus..."

“I said I can't play today. We can tackle calculus tomorrow. Moses, I need to talk." "Since you finished Level Two in such good form, I think you deserve a bit of free-forall time. Do you want to go anywhere in particular?”

"I need some advice."

“Then you are in luck. I am an advice device! You remember I'm not actually, you know, human." His avatar morphed into a white rhinoceros, still wearing the coat and tie.

“Cut it out. I know you're a game piece.”

"I’m your game piece, Sam."

“How do I convince my father to let me into the grange?”

Moses's avatar morphed back into its usual Bantu costume.

“Family advice. I see. Well, that's a problem for me. I have no real family, except for you."

His avatar walked in a small circle. He lifted his head. "I know!" He stopped and stood. His legs wide. "I can pretend to be very angry with you for wanting to join a Game grange. You can practice your arguments. Hone your logic."

His face became a stern mask. "This grange, it's nothing but a filthy communist hangout. No place for a good girl like you!" He shook his finger at her.

“Moses, don't..." 
"First, they will seduce you with their passion and their earnest save-the-earth vision. Then they will steal all your money. Then they will want all of my money." Moses's hands covered his face in dismay. Then he pointed at her and shouted. "No, you must never even think about such a place! Now go to your room!"

"I'm in my room. Moses, this is not helping."

"The boys you meet there are all horrible slackers who have nothing on their mind but what's inside your knickers. Knickers? Is that the right word?" Moses's face became quizzical.

“I'd go with panties.”

"Ah, yes. Where was I? They will pass you around like a...a box of cheap chocolates! I will not stand for it! You... you should be protesting at this point..."

"Do you believe that's really what he's thinking?"

"Other guides have reported such sentiments. Mostly parents want to protect their children from making mistakes they will later regret. They also envision a future for you that is constructed from past dreams of their own future. The grange is too new to fit into these."

"So, I should try to live some dream they had for themselves?"

"Maybe just try to show that the grange is not so foreign as they believe."

"I should be more positive?"

"Precisely."

“OK. I'm positive he's not going to let me join. Stay tuned.” She closed her laptop.

\section{$\S \S \S$}

A couple weeks back, Samantha had finally confronted Dwayne about joining a grange. She needed his signature on a form.

"What about your back-to-school shopping?" he said. They gave her a thousand dollars a week for clothes and whatever. Her junior year started in weeks, and she would normally have been frantic, asking for extra cash. 
"I have plenty to wear," she said.

"You what? I should be videoing this," he made a show of pulling out his phone. "Can you repeat that?"

"Just sign the form." She slapped it on the table.

"You want to join some hippy commune?" His smile was not jolly.

“It's not a commune. It's a cooperative. You know, like REI.”

"Well, they took a perfectly good car lot and turned it into junkyard. Listen to your father. You're going to be really busy when you get back to school. Junior year is hard. And you want to be in the honor society."

"You mean you want me to be in the honor society."

"Your brother was."

“Well, one out of two isn't bad. Besides, grange plus honor society equals perfect world. Yes?"

"I'm afraid I'm going to be firm on this one sweet pea."

Samantha glowered at him. She could see him measuring her resolve. It was time to play her card.

"I ran into Kittie Dakota at the mall," she said crossing her arms.

"What's Kittie up to this summer?"

"She said to tell you her mom says hello."

"Sierra's a good client." Sierra Dakota had been a supermodel for ten years. She got divorced in May. Kittie told Samantha she saw Dwayne slinking into their pool room where her mom was supposed to be resting.

"Kittie says..."

“Maybe we could take a look," Dwayne said. "No promises." He poked her shoulder. "They have a tour on Saturday..."

“No promises. Right?” 
"Right. Right. It starts at eleven."

\section{$\S \S \S$}

In the shower, Samantha rehearsed a picture of the grange that highlighted its real, although strategically hidden, capitalist mission. High technology and advanced design crowd-sourced from the brightest young minds: all devoted to capturing an emergent marketplace where innovation and sustainability crafted an enormous return on investment. Her father would look right through this picture and just laugh at her.

Drying off, Samantha's trepidation returned. In any possible world she could imagine, she would be locked out of the grange until she was eighteen. She examined her face in the mirror. It was not a bad face, all the parts were arranged pleasantly. Her parents were both supposed to be handsome. The boys at school didn't run away from her. She thought her boobs were only so-so, but the boys seemed to stare at them anyhow. Her mother had prompted her to try out for cheerleader, but Samantha chose lacrosse. She dried her hair.

All the best Gamers were joining granges. At least she still had her lacrosse buddies at school and Level Three on the Game. And she could spend more time downtown at Red Star Coffee and work on some badges on her own. She wriggled into her Hat and Chaps jeans and a t-shirt and slipped on her Game shoes. She pocketed her phone and a couple Shine stones, including the white one that the Game gave her for winning Level Two.

\section{$\S \S \S$}

Dwayne wasn't in the kitchen. By the half-empty pitcher of Bloody Marys, she figured he was around somewhere. Sam found him at the foot of the driveway retrieving the newspaper. She gave him her best hug and acted really sweet and, like Moses would say: positive.

Dwayne put his arm around her as they walked up to the house.

"Your mother caught you cleaning your toilet again," he said when they entered the kitchen. 
"You make it sound like I was shooting heroin."

"We pay Lupita good money to do that for you."

"Shoot heroin?"

“No, silly, clean your toilet."

"I'm sure she doesn't mind."

"Hardly the point, Sweet Pea."

She hated when he called her that. It meant he wasn't actually even faking that he was listening to what she said.

\section{$\S \S \S$}

“Dad, time to go," she called out. Dwayne was usually punctual, unlike Sheryl, who was only on time to events of her own choosing.

Samantha opened the front door. "I'll meet you at the garage," she yelled over her shoulder.

Outside, the day was already heating up. She figured Dwayne would want to use the Porsche, as the grange was five minutes away. He reserved the Aston-Martin for road trips.

"Dad! Come on. We need to go now!" she called. She could still hear them arguing. Sheryl, shrill as a jay. Dwayne, more contained, but holding his own. She stepped outside and shut the door. Dark clouds of foreboding settled over her as she walked on the sandstone path through the carefully manicured front garden.

She entered the five-car garage through the side door and tripped the opener for the Porsche's roll-up door. At the far end, Sheryl's Range Rover and the hulking Ford 550 were parked next to the empty spot where Samantha's car would have been. The pickup barely fit through its own roll-up door. Her birthday Beemer convertible was gone, back to the dealer. Her twelve speed bike leaned against the wall.

\section{$\S \S \S$}


"Try again, Joseph. And keep thinking."

"I am thinking as hard as I can," Joseph studied the tapestry on the stone wall of the great hall of the castle. "Something is missing. The most important thing of all."

Amitabh's instructions had been simple. "In this castle is a tapestry that shows every item in the castle. Every person. Every object. Every activity. You can see the cooks in the kitchens and the king on his throne. The queen's dog likes to piss in the corner. Look, you can see the stain. The princess lets officers into her bedroom. Here's a clue. You won't find what you seek there. Something is missing from the tapestry. The most important thing of all. When you find it, you will complete this palace and Level One."

For days, Joseph searched the palace, examining the tapestry, and evading the guards, who chased him, shot him, and imprisoned him. Once they even cut off his head. Amitabh was nowhere to be found. No help at all. In all the other palaces, Amitabh had been by his side. They had fought their way out of dungeons, puzzled their path through mazes. They were captured and needed to trick their way out of captivity. Joseph did not like being alone. Alone and stumped.

While he punched decorations into leather, Joseph puzzled. The tapestry was now a photograph in his head. Its threads and knots inscribed into his memory. The crown, the jewels, the prince and his sister; what else is important for a palace? What is important for Joseph? Food and water and clothing. All of these were plainly visible in the tapestry. Nothing is missing. The crown sits by the king's bed. His scepter is in its case next to the throne. The queen's jewels are locked in an oaken chest in a strongroom guarded around the clock.

Joseph had visited every space, ducking around corners, making himself small in the shadows. He spied on guards and maids, on the king and on his daughter who did let officers into her bed where they wrestled like cats in the street.

“Try again, Joseph. Keep thinking. Open your mind. Don't get too close to the problem." Amitabh shook his head. "I thought you would have solved this by now. Maybe..."

"Give me another day!”

"You have until forever, but you will not move ahead until you discover what is missing." 
Timed out after his ten minutes, Joseph stumbled away from the computer confounded and angry. He had been all over the palace, even to its top most turreted tower. He had counted the flags, and... "Wait!" He stopped and took a long inbreath.

Joseph turned back and joined the end of the line. There were five in front of him. "Of course!" Inside, he was dancing. His breath came in great gulps. "Hurry up!" he whispered wanting to shout.

"If you need to pee, go over there," the boy in front of him said. The line moved ever so slowly forward.

Joseph reached the front and put his thumb on the square.

"Back so soon?" Amitabh said. He stood in his room with the desk and the computer.

"Show me the tapestry," Joseph demanded. The tapestry appeared. Every thread was as he remembered. Yes. Something was missing.

"It's me!” he said. "I'm missing."

The scene changed back to Amitabh's room.

"Very good, Joseph." Amitabh clapped his hands. He folded his arms in front and grew stern. "Now, what does it mean?"

"I assumed that I was just a part of the whole, but I am also a watcher. I see the palace, and I am surrounded by it, but I am also apart from it. I am missing even though I am there."

Amitabh nodded, then he spoke. "The palace is you. The watcher is also you. The watcher is your mind and your self. You are in the world and of the world. Yet you are also apart from it. When you sleep the world goes away."

"When I go to sleep I go away. The world stays as it is."

"Both are true. Your mind is shaped by the world as it shapes the world. This doubleness is the lesson of this palace. Do not think you can reduce the world to something where you are absent. And do not think you can simply make the world by your presence. You and the world form each other. You make the world, Joseph. But not by yourself or for yourself. The world also makes you. Sometimes you must let it. Other times you must resist. The Five Skillings will teach you when to choose." 
"I don't follow..."

"But you will. Congratulations! You have completed Level One. Prepare yourself. Level Two is designed to kick your scrawny ass!"

"I'll be the one kicking ass," Joseph said. Amitabh winked and the screen went black.

\section{FOUR}

On the morning of the second Saturday of each month, Megan Doolan gave a tour to prospective grange members. Some of the several dozen people standing before her in the grange's center room had recently earned their shoes in the Game by defeating Level Two. Some of them were transferring from other granges. A few were parents of gamers, investigating this facility before they give their permission. Many of the gamers were not yet seventeen years old. Megan looked at the youngest ones, and tried to remember when she earned her shoes, back before the Great Games, before Shine and jikan and WholeTale, before granges, before even the GameTowns. Megan remembered the day the Game door first appeared in Junana. That was a decade ago. It felt like a century; back when she was fourteen.

Megan gestured with both hands and used her announcer voice. "This space supports a wide variety of arts and physical practices. There's a screen for video nights.

Dressing rooms and public bathing areas through those doors." She pointed. The tour turned their heads in unison and then turned back.

The big room was being set up for a Master Lu style exercise class. Several grange members of both sexes and broad range of ages and dressed in casual yoga wear, were on their mats warming up. A handpan drumming soundtrack percussed in the background.

"A schedule of classes, talks, and performances is available online," Megan continued. "The gumis manage entertainment by the month, and handle cleaning and maintenance. Your dachi will keep you informed about your responsibilities. You should 
read the grange user manual as well. You will need to pass the test to get your basic user badge before you can get your keys. We run a Game B economy here. You'll need to ask your Game guide for the commoning templates you'll want to master to get in on all the conversations around that. Skip the homework and you will find it really hard to truly belong here." She looked about the crowd. The level of puzzlement was high. She stopped and help up her hand.

"All right. Short explanation, particularly for you parents and noob Threeveys. Number one: Let's talk about provisioning. Globally, we've now got several hundred thousand granges that form an interlinking commons across the planet, and most have manufacturing capabilities at some level. So we make pretty much everything we need, and we do so as close as possible to where it will be used. We operate two electric bicycle factories in Goleta that supply five counties, and a medical robotics factory that supplies the planet."

"What don't we do? Well, we don't make computers here in Santa Barbara. We get them from the Grange foundries in Ventura and LA. We can upcycle your Apple or Dell for you and give you a Grange model that you will never need to replace, because every part is individually replaceable. Same with phones and pads. And we have Grange designers across the planet always hungry to improve the specs and aesthetics, so these are not last decade's tech. We generate more electricity than we use, and store the surplus as Hydrogen, which we can use for transportation."

"Household goods and hardware, you can pick this stuff up at one of the local General Stores with a Granger discount you will appreciate. These carry everything your Gumi house might need. They also use sharing bins, so you can donate anything you're not using anymore, or pick up a used item for free."

"Local granges run coop cafes around town. Yes, we grow our own weed, if you're old enough to partake. The local coffee crop is also excellent; another reason to love Santa Barbara. Food, we grow as much as we can, trade for the other stocks regionally, and buy specialty goods, spices and such, from the global grange network. Transportation is shared, from skateboards to heavy trucks, as are tools, big toys, sporting goods, and all manner of equipment you might need once and a while."

"You can access more goods than a millionaire in the last century, and not own anything. Clothes are available in our sharing rooms. We are on the way to providing our own health services including emergency care, and we self insure for a range of risks. The global sharing union coop provides financial services almost at cost. We 
have the talent in-house to fix anything wrong at our properties. In fact, we can build a tiny house in a single day on your land, or a small apartment house in a month."

"Number two: investments and consumption. We use surplus funds when available to buy more farmland and housing. All of our land is put into a trust, so is our intellectual property. These can never be resold outside our Grange cooperative network. We do sell some high-priced, high-value goods to the rest of the world through the internet and WT shops, but we don't need to do this. We just make so much cool stuff, the world comes knocking. Everything we make, use, and consume has a net-zero impact on the planet, as close as this is possible today. We are getting better at this. We have millions of researchers and SpimeCops figuring this shit out. You can join them after you level up in the Game."

"Number three: learning. We pool resources to help those who want to pursue active learning, knowing that their accomplishments will come back to us with added value for the community. We support life-long learning through the guilds with their badges, and through academic granges, in what used to be the local university. We offer free Helping Mode childcare from birth to pre-kindergarden. Our after-school programs kick in at that point. You can visit the crèche; it's at the back of the lot. Plenty of little Grangerats there who want to play. On the higher-education side, we have joined together with the three-thousand California granges to lobby for increased state investments in basic science research and a more coherent information commons. And we host weekly PechaKucha discussions on science topics of local interest."

Megan knew that only a dozen new members would get invited to join. The grange's population hovered around it's max, 1700 members, including a handful of ronin Gamers: Sixers and Meisters who had completed a range of advanced badges and were welcome in any grange. Mura members were invested as partners in the grange, which was incorporated as a cooperative association under California law. You need to have passed Level Two in the Game to be invited to join. You buy your share, pay monthly dues and volunteer the required jikan hours. Those without funds can pay off their share through additional jikan, or their dachi might do a fundraiser event.

Each grange was its own experimental laboratory for the emergent commons-based economy. One part of Megan's job was to log the social friction points, the rough edges where personalities and collective goals collided. Some days she felt like a one-person complaint department. She could call on her guild for advice, but usually these problems were settled through small-group conversations around the templates for participation in a sharing economy. 
There were already five granges in Santa Barbara city, and fourteen in the county. When the waiting list in the county's granges exceeded a thousand, those on the list were encouraged to create a new mura, which would look for a space for a new grange and incorporate their own cooperative. Besides abandoned car lots there were other available relics from the past century: empty industrial parks, closed big-box stores, vacant strip malls.

"Ours is the oldest grange in the county," Megan said. She walked toward the door. "... And one of the first thousand granges in the world. Here is our sharing union ATM." Megan pointed. "All grange members can join the sharing union. I have the paperwork, or you can visit the main branch downtown. Over there is our Red Star Coffee cart. Try the blueberry muffins. That's Felicia, making espresso this morning." She waved and the barista smiled.

"Here's a challenge," Megan said. "Make a list of the templates you see on the tour. At the end, give this to Felicia for a free cookie. I'll start you with a tip. If you find more than twenty different templates, she will also make you a free latte."

Megan continued through a side exit and waited outside. "On your left is our on-site cafe, open early and late. Gumis also run several cafes around the city. Cafes, like the baths, are $100 \%$ phone free. You can go outside to use your phone."

She walked backward as she talked. "Listen up. The grange is about learning and teaching, making and sharing. The building on my right is our main equipment sharing center and tool library. Everything from power drills to back-hoes, and from camping tents to hang-gliders, are available here. You have it when you need it. If that tent you like is already checked out, we have reciprocal deals with other granges. Most equipment only takes a basic badge to use. You can reserve tools online. If you're late returning them, you get to talk with Dina. Morning Dina!"

Megan waved and a woman in a maker t-shirt and jeans waved back.

"In the central building we also have a media sharing library, with actual books, mostly sci-fi and mysteries. Follow me."

She waited for them to gather around her in between a row of buildings, each with its own roll-up garage door, several of which were open, revealing activity inside and the sound of machines at work. "These are our state-of-the-art hacker, maker, crafter, fabrication, and rehearsal spaces," she said. "Here, we can make most home furnishings and hardware, clothing, toys. Other goods we make in our factories in 
Goleta. For example, we supply shampoo and toothpaste for most of the region. We repair and reuse everything we make. Like I said, we have a team that can build a tiny house in a day."

She turned in a slow circle, catching the eyes of her listeners. "We produce music, podcasts, and videos, from two-minute YouTube vids to full-length narrative movies. We teach writing, camera, sound, and editing; all up to master badges. Many of our early members have gone on to lead production efforts at other granges, colleges, or GameTowns. We reserve the grange space for teaching. We also run a large factory out on Hollister Avenue where we make and sell fine home-ware and fashion items for the General Stores and through the WT store chain and online store, and we are active in the open design movement. Most of our products have WholeTale ratings above seventy-five. Each of these forms of production is guided by a master maker, crafter, or artist. Why not take half an hour to look around. Then we'll gather back at the Center to wrap up, and I'll answer questions."

"Also, please do not enter the fabrication workrooms unless you have the appropriate badge to do so. You can talk to anyone you want. They are mostly friendly. Our kitty-cat lounge is over on the left. If you like cats, stop off and enjoy. Dogs you'll find on the farm. Remember to close the gate. Stay away from the post-production suite. The building at the far end. They are hard at work today."

“Post-production?” someone asked.

"They are finishing the edits on a community-based narrative film. Something about a tragic/comic college romance. On Monday this has to be sent off to Sundance. They've warned the grange they will be working 24 hours a day until then. We drop off lattes and scones every hour."

Megan fielded several questions, mostly from the parents who were not gamers and had no sense of Shine or jikan. She had answers that she knew they would not really understand. Answering their questions on the spot was like explaining quantum entanglement in an elevator. You cannot really understand jikan-beyond the simple fact of an hour spent in service is an hour banked for later-without getting into Shine, badges, and the whole sharing economy. 
“Dad, no. Please!” Dwayne had been silent, almost grim on the ride over to the grange. When they arrived he spotted a handicapped parking space and dipped into it. $\mathrm{He}$ hung a blue card from the mirror. Lupita's husband had badly sprained his ankle working on their property up in the valley. Dwayne paid for Juan's doctor visits, but he insisted that Juan apply for a parking permit during his rehab. Dwayne saw no reason why anybody should get preferential parking access unless he got some too.

“We can just go home," Dwayne said. Samantha sighed and slammed the door.

"We're late." Samantha set off for the main building. "Come on."

Inside, the tour had already assembled. Samantha checked in and took a name tag. The grange manager was describing the many uses of the space. Samantha strained to hear her. Dwayne seemed more interested in a pair of women in athletic bras and tight yoga pants stretching on their mats.

The manager, whose name was Megan, led them outside around to one of the rows of out buildings that had once been the dealer's service department. They stopped near the first open bay. This was surrounded by bicycles and scooters.

Megan described how the grange worked. Samantha could borrow a bike, a scooter, or even a car any time she needed one. And they were all electric or hydrogen powered.

Samantha peeked at her father's face. He was frowning, slowly shaking his head. Not really listening.

Megan talked about all the capabilities of the grange. Samantha glanced through the open door of a nearby sewing workshop. A dozen makers were at the machines. She turned back to listen to Megan, who had just said that they were finishing up a movie that very day.

“A movie, dad," Samantha squeaked. "They make whole movies here.”

Dwayne spoke up. "Tell me about shine. Sam is always going on about her lack of shine." Samantha glowered at him.

"Shine is easy to understand and yet hard to describe." Megan said. "It's a measure of your reputation. A composite of what you have accomplished and what people acknowledge about you as a person."

He raised his eyebrows. "So, it's nothing new." 
She continued. "What's new is how it's counted, and how much it counts. You might be the world's best violinist and still be the world's worst friend. The first will earn you some Starshine, which is durable reputation. The second will cost you Sunshine: your day-to-day reputation. Shine doesn't care what work you do, but rather how well you do it. Why don't you pick up our annual report before you leave."

She turned to Samantha. "How many templates have you found so far?"

Samantha checked her list. "Twelve."

Megan said, "Here's a hint. Check out the farm." She started to walk away.

Dwayne called after her, "So, this is what you call 'utopia'. People working their asses off for no money."

Megan halted and turned, walking backward away from them while she spoke. "We don't call it utopia. We call it life. And it's not work. It's a hunger to know more. It's an opportunity to do more. A chance to feel more. Money comes and it goes. Shine grows." She turned around and strode away.

Samantha watched her go, thinking that any chances she might have had to join were now history. "Thanks dad. Real cool. I'm off to see the kitties. Don't follow me. I'll meet you in half an hour at the Center."

\section{FIVE}

Be positive, Samantha told herself, as her mood descended into gloom. She entered the Kitty Room, a space dedicated to the grange's shared cats, furnished in a jungle gym of carpeted perches and walkways, with food on one side and litter boxes on the other. And yes, there were kittens to cuddle.

Ten minutes with a dozen purring cats was like a tonic for Samantha's soul. They never could have cats. Sheryl was allergic. On the way to the farm, Samantha walked past a furniture fabrication shop, where chairs were being stacked as they came off a 
large sintering press. As she watched, the operator, having just reassembled the press and attached some hoses, lowered the clear plexiglass safety screen to start the process.

While the next chair was being molded, the maker, a woman of uncertain age in a canvas apron over jeans and a t-shirt, her hair ponytailed under a short-brimmed baseball cap with a bright CraftMaster pin on it, carried the just-pressed chair to another table, very near the open door, turning it over to expose the bottom of its seat. She positioned a laser embosser on a flat space slightly thicker than its surround, and punched a key on a nearby keyboard.

She noticed Samantha watching the process. "This will put the WholeTale QR code on the chair," she said.

“What's its WholeTale score?" Samantha asked.

The maker looked over at the computer screen and moused to a different page. "Hmm. Very good. Just above 91," she said, reading. "Some of the farms for this lactic polymer may still be using petroleum-based fertilizer. One of the warehouses has been accused of not paying overtime wages. Our maker press has a less than a hundred percent lifecycle-analysis rating. The Life Cycle Assessment is never totally clean. Although we're off the grid here, there are some external energy load costs in the manufacturing stream. Two years ago, this chair would have been in the low 80s. I imagine two years from now it will be in the mid 90s, if the Spimecops keep up the pressure."

"You looking to join the grange..." She glanced at Samantha's name tag. "Samantha?" "If I can talk my dad into it. How long have you been a member?"

"I lost my job at UC Santa Barbara three years ago when they disappeared the philosophy department. I had just earned my shoes, so I joined the grange the next week. Excuse me."

Samantha watched her set the QR embossed chair on a stack of similar chairs. They were a uniform cafe-au-lait brown color. She had seen a similar chair at the WT store downtown.

The woman walked over to the maker press, raised the shield and, with gloved hands, released the next chair from its mold. She lightly trimmed any extra plastic from its powder injection points with a razor knife, and then burnished these spots with a small rotating tool. She rubbed the interior of the mold with a rag, assembled the mold, 
attached the hoses, closed the shield and pushed a button. The maker was humming a tune as she carried the new chair over to be embossed.

"Do you miss teaching philosophy?" Samantha said.

“Oh, I still teach philosophy," she said. "Our academic badge guild runs massive online courses in epistemology and ethics. To be honest," She stepped up to the doorway. "I like making stuff a lot more. What's your name?"

"Samantha." Sam pointed to her name tag.

"Yes, I can read. I mean your Game name."

“Samantha2043"

The maker went over to a laptop computer on the counter near the laser embosser. She typed for a minute. The embosser registered its target space and then started cutting. The air was scented like candy.

"Smells good. What did you just do?"

“The PLA polymer is made from a type of sugar. It's like creating candy furniture. Smells a lot better than ABS. Every chair is its own spime. From the time it's born...," she pointed over to the press, “...to the moment it's reduced to polymer to be reborn...," she grabbed up a handful of colored powder from an open container, "...a record of where it goes and who uses it is added to its WholeTale data. I just wrote that Samantha2043 watched this chair being made."

"Shiny!"

“When you join a mura, you'll get your spime app. Every time you buy or share a spime, all you need to do is scan the code and you'll be added to the list of people who got some use from this."

"If I ever get to join..."

"You earn your entry level maker badge and come to my class. We can teach you how to make a lot of the things you use every day."

"But, it's just..." Samantha raised her hands, "...a chair.”

"That's a fact. And while it might be hard to sit down to dinner without one of these, there is not too much to be said for it." She looked back at the computer screen. "It 
was designed in Finland by Jussi Posti. The design won the Castalia prize in its category two years ago. I imagine Mr. Posti got a whole lot of Shine for that. His design was then forked and tweaked, let me see... three times, so far. The local gumi chose the modified design and ordered thirty-six of these. They could go to Target or Halmart and get a standard plastic chair injection molded in China for a tenth of the price, which would totally fucking miss the point of this entire enterprise."

She stepped out of the workshop and put a hand on Samantha's shoulder, turning her around. With her other hand she gestured across their field of vision.

"Look at this! It's all philosophy in action. Once we can make everything we use, and design everything we want; once we can design and make the machines we use to make everything else; then, we will have recaptured the knowledge we gave away to big industry a century ago. There is nothing they can sell us that we would not rather make and improve upon through our own devices. You can see the big " $G$ " on my press."

Samanta looked back nodded.

"That means this is a grange built factory. It means there are no materials in this shop that we cannot reuse, upcycle, or apply as nutrients on our farms. It means nobody else on the planet needed to suffer so that we can shed a percentage off our costs."

Her hand guided Samantha back to face her. "It's not the making nor the having. It's the knowing how to make and what to have that is being built here today. This is a lesson in applied epistemology. In six months I'm taking a year off to make a series of videos about this. I call it 'epistemography,' the study of knowledge in places. I also get to add another five hundred or so words to the philosophy corpus on SilvasAcademi."

Her hand still gripped Samantha's shoulder warmly. "Samantha2043. I'm in the Horse gumi. Best gumi in the whole mura. We are dedicated makers. We can help you make a life anywhere on the planet. We can teach you the philosophy of chairs."

She let Samantha go and stepped back into the warehouse. "Now off with you! I've got twenty three left to make this afternoon." She gave Samantha a little wave and started to whistle. 
In the middle of the lane between the various workshops Dwayne spotted an hexagonal wooden kiosk bristling with notices. At the top of the structure was a sign: "One- and two-day events have priority. Post longer classes and festivals online." Under this in smaller letters: "Shared transportation board at the transportation center, lost and found board in the main center."

Each side of the kiosk had its own heading. Dwayne walked around the kiosk reading: "Athletics, yoga, and martial arts; Music, dance, and drama; Lectures and hackathons; Celebrations; Stuff to share; and Frolicks and flash mobs." Each notice was time stamped. He stepped closer, mumbling to himself as he read.

"Goddess at the Core: awaken the goddess in you. Radiate the love you store inside. Find the ancient wisdom that resonates at your core..." New age crap.

"Be a Shaman: Holotropical breathing." He read on, more ancient native wisdom here too. Drumming, fires, vision quests. Probably hit each other with sticks. He stepped around to another surface.

“Erotic tattoo photo exhibit. Funk-zone grange gallery, August 20.” Another reason not to let Samantha join.

"Nude figure drawing...:" That's more like it, he thought, then he read on. “... Rediscovering the timeless beauty of the aged. Bring in your grandmother or anyone over the age of 80." Woah. They would not find him anywhere near that.

"Have access to postproduction video editing suite for six months. Am willing to share with three other teams."

"Horse ranch in Los Olivos will share bed and board and pay living wage and jikan for three horse wranglers starting August 1." On he went.

Celebrations were limited to the current week. Even so, there were dozens listed. A lot of "badge bashes" and "guild gatherings". So many excuses to get out of work. The next panel was even weirder. What the fuck is a "frolick?"

"Building a lesbian frolicks team for Burning Guy. Must be good with fire-spinning and basic acrobatics (non-aerial). Nudity is not optional."

"Crafting a visual frolicks on side of local building on State Street. Interested? Meet me at Red Star downtown August 12." 
Sports had their own panel.

“Learn laughter yoga in a day.” Laughter yoga?

“Ultimate frisbee tourney on the beach..." Dozens of different sports and martial arts events. Keeps them off State Street, he figured.

Even more music events. So many they were piling up on top of each other. How many places had live music in the area, he wondered? Everything from celtic fiddle to sitar. None of them had any kind of ticket information. Just hashtags.

A portly middle-aged woman in baggy jeans and a cheap T-shirt and not a trace of makeup walked up to him. Her hair, streaked blonde and white, was pulled back in a clumsy ponytail. "You looking for a particular event?" she said.

"There is a lot going on here." he said. Most of it fucking bizarre.

"This board is for the whole city. Not just one grange."

"Plenty of nudity and tattoos, I see."

"Lots of music and learning too," she said.

"I don't think my daughter is ready..."

"It’s really a very good place for teens."

"Sure. Get ripped off when you're young. It builds character."

She looked away and then back at Dwayne. "My son was, well, he was kind of lost. Did some things that were stupid. Then he got into the Game and he joined a grange up in Pismo Beach. That was two years ago. He's earned a full share. He has a bed in a gumi house, he works as hard as he wants, and he's learning real skills. He gives as much as he gets. He's as happy as I could ever imagine. My daughter is also hoping to join this grange." She pointed over to a younger, fatter version of herself.

"Gee lady," Dwayne said. "I'm sure glad your son escaped incarceration so far. My daughter gets straight 'As' at her private school, and she already has a trust fund that's worth more than this entire operation."

Dwayne faced her and stepped in a bit. He gestured widely with his arms, warming up to his rant. "She will inherit an apartment in the very center of Paris, another in Kensington, a condo facing Central Park in Manhattan, a membership in the 
Yellowstone Club, a house on the ocean at Kona, a mansion in Hope Ranch, a horse ranch and five hundred acres of grapes up in Santa Ynez..." Including a hacienda-style shag shack his wife used with her cowboy- and ex-hollywood boyfriends. “...and several billion dollars in tax-free, offshore accounts. She doesn't need to 'give as much as she gets,' because she's already fucking got everything she'll ever want."

He expected the woman to wilt and, maybe even start to cry, but she stood there and watched him.

"You forgot 'happiness'," she said. "Asshole," she muttered. She turned and walked away. He saw that she was wearing the same shit brown felt shoes as Samantha.

He glanced at his watch, an antique gold Patek Phillipe chronograph worth more than most people's houses. He looked around for Samantha. He pulled out his phone. The email counter said "twenty-three." An idea emerged. He could read his mail while he checked out the women in their yoga pants back at the Center.

He was strolling in that direction when a young man, more a boy, dressed in some kind of flowing grey robe, a conical hat, a cloth bag slung over his shoulder, and what looked like rope sandals, came right up to him.

“Oh fuck,” Dwayne mumbled. Some kind of religious nut.

"You look lost," the boy pushed his hat back, it fell off his head and slid to his back, suspended around his neck by the chin strap.

"I'm good." Dwayne nodded and picked up his pace. The boy matched his stride.

"You seem out of place. Are you lost?"

"At least I don't look like I escaped from some ninja movie."

"I'm Fred." The kid stuck out his hand. "I'm getting ready to go on walkabout. I just need to finish off a couple badges."

“Dwayne Mooney," Dwayne gave the hand a quick shake. "Now, if you will excuse..."

"Let me buy you a cup of coffee. You headed back to the Center?"

"You want to buy me a cup of coffee?" Dwayne glanced over. The kid was smiling brightly. "How about a nice caramel latte, while you're at it."

"Sure!" They had reached the door and the kid opened it for him. 
They settled at a table by the window wall. The kid went off to order. Dwayne glanced over at the exercise class. The participants, mostly young and lithe, were all on the floor, and appeared to be planking on rubber balls the size of large grapefruits. "Try to roll on every inch of your body," the instructor said. There was a svelte blonde who he had just started imagining rolling on every inch of his, when Fred came back with the drinks.

"Somehow I figured you'd be a whipped cream guy. But you can spoon it off if you want." Fred sat down. "You're not the one who wants to join, are you?"

“My sixteen year old daughter."

"I'm sixteen..."

Dwayne looked at him. Fred was small, slight. His eyes looked older, but his face looked much younger. "Sure you are."

“...or I will be, soon enough.”

"Where are your parents?"

"Mom is back at the gumi house with my little sister. Dad... he's been gone for a long time."

"You live in a gummi house?" Dwayne took a long sip. The latte was excellent.

Fred laughed. “It's 'gumi.' I belong to the Tiger gumi of this mura. I'm in the Rat dachi."

"That is so you."

"Four years ago, we lived in our car."

"I know what you mean. I commuted to LA for a couple years."

“Oh, we hardly ever drove it. Never had any money for gas."

"You mean you were homeless."

"I prefer to say we were Camry-full." It was his mom's joke. She told it like fifty times after it had stopped being funny. 
Dwayne glanced over to the blonde, who was now standing and toweling off, chatting with her friends. He looked back at Fred. "What's with the costume?"

"I've just earned my SilverSurfer badge." The robe had a lapel, which he lifted. Beneath it was a small metallic pin in the shape of a surfboard. "I'm going on walkabout in a couple months, after Burning Guy."

"You're a bit young for that, aren't you?"

"I am a Fiver." He looked back at Dwayne, who showed no reaction. "It means that I'm on level Five in the Game."

"Good for you." He looked at his watch again. A couple minutes before Samantha showed up. "Me, I was a late bloomer." That's what his parents said to their friends. What they actually did was keep him back a couple years so that he could out-compete the other kids at varsity tennis.

"The Game decided I could play when I was eleven. That was just after the gumi let us stay in one of their houses."

"Ah, I see. They got money from the city." Which got money from the state, which tapped into some federal program, which would have used his tax dollars, only he didn't pay any taxes.

"I don't think they did. Most gumis in the area sponsor families that need a new start."

"Out of the kindness of their hearts. I'm touched."

"Pretty much. Although nearly all of these families later become full grange members. My mom is a full member, too. She's with the Snake dachi. They don't put us in the same dachi. That would be weird."

"How many homeless are we talking about?"

"I don't know. All of us, I would guess, except for the stonehearts, and those who fail to earn their shoes after three years."

"Stone hearts?"

“That's what my mom calls them. Some people cannot live well with others. A few might be dangerous. Mostly they are not, you know, considerate of others. Always in your face. 'It's not their fault,' she tells us; 'They have a stone in their heart.' She 
didn't want us to think they were all crazy. We kept well clear when we were living on the street."

"How can they afford to feed and house all these bums. The government tried it for decades and never had enough money."

Fred said, "The proper aim is to try and reconstruct society on such a basis that poverty will be impossible."

"You read that somewhere, right? Samantha's starting to quote random shit. Let me give you some advice. Stop it. It's fucking annoying."

Fred's smile dropped, he eyed Dwayne warily. "There's plenty of jikan to share. Kids and old people need attention. Gardens need tending. Nobody is fed or housed who doesn't earn their meals and futon, except the kids. Who can object to a kid having fun? Everybody gets a chance to earn their shoes and join a grange. Little Annie, my sister, will become a member as soon as she earns her shoes."

"What if she wants to go off into the real world and get a job?"

“'Real world.'” Fred smiled again. "You're funny.” He made to stand up.

“Tell me. How much money do you earn in a month.”

"That's kind of hard to figure." Fred settled back and stroked his chin, looking up at the ceiling. "I earn basic wage, like everyone. That's double the Federal minimum wage. After my dues are paid, and meals and rent, I save about twenty-five dollars in my sharing union account. I bank a lot of jikan for later. And, of course, I get BJ..."

“What!” Dwayne said. The kid must be joking.

“Bonus jikan. I get five minutes for every hour I work or donate for when I'm sick or want a day off."

“Where do you work?"

"I work here or at my gumi house, or sometimes at one of the gumi cafes. It's all the same account."

"How many hours a month is that?"

"Varies. Some days I work seven or eight hours. Usually I work three or four." 
"No wonder you want to get out of here." Maybe he should let Megan join up. Teach her to trust her dad and not her instincts.

"What? Oh, no. I'm just going on walkabout to get to know more about the world out there." He gestured toward the window. "What did you call it? Right, the 'real world.'”

"You walking anywhere in particular?"

"It's not really walking, I'll get rides in shared cars and I can take some trains. Then there's AirCraft."

"AirCraft?"

“Not here, but in Europe and Asia and lots of places. The new dirigibles."

"You going to Europe then." FIX News had been following the FAA's struggle to keep these new Hindenburgs out of the air traffic lanes. Each one was filled with enough hydrogen to toast a small town if it crashed. They were a big hit in Europe. But who in his right mind would choose to spend an entire day and night to get from LA to New York? “Ever been to London?”

"I've never been to anywhere. Except on Junana. Well, I have been to Ventura a couple times."

“Expensive place, London."

"I've got invitations from Tiger gumis in Chicago, Paris, Rome, Venice." Fred thought a bit. “New York, Tokyo, London, Cairo, Mumbai. Places like that.”

"See the world, then. Sponge off your friends."

"I've saved up all the jikan I'll need. And I have badges, so I can work. I have some Shine. I pay my own way."

“Then it's back home working to save twenty-five dollars a month? Is that your plan?"

"I hope to come back here to live. I like it here. First, I'm off to a college for a couple academic badges. I've been thinking about biochemistry and nanotechnology."

“Really?” Dwayne was expecting something more like barber school or hotel management. 
“There's a college in Boston, or somewhere around there. They've offered me a spot for next year. Beadle College. It's part of what used to be Harvard University."

"Yes, I've heard of that." Dwayne considered that Fred had been conning him all along. Maybe he was being set up by that grange woman, who was just now emerging from her office.

Samantha came through the door. Dwayne waved at her and she lifted her chin in reply. "That your daughter?"

"Samantha."

"Wow. She looks..." Fred sat up straight and stared. "I mean. She must be..." He was wide-eyed and speechless as he watched her approach.

"She's all of that." And far more than you could possibly handle. Dwayne was also impressed, afresh, by his daughter's presence. She walked on kitten feet, light as a dust mote and bright as a sequin. She was too good for this dump, he figured. But he knew she would not take his decision well. He glanced back at Fred. The kid was probably lucky to be wearing a robe.

Samantha stepped up. "Who's your new friend?"

Fred, to his credit, jumped up and offered his hand. "I'm Fred Hardy. We were just talking. Take my chair."

Little Freddy was way out of his league.

"Fred is going to be sixteen soon." Dwayne knew his daughter would not look twice at someone younger than she was. "I think we're expected over there." Dwayne stood and pointed to the crowd reforming.

"My dad's right. Nice meeting you. I hope to see you around the grange."

"Sure. You too."

"Son, do you know who I am?" Dwayne said.

"I know you are a very fortunate fellow, to be the father of Samantha." Fred's smile was not for Dwayne. 
Dwayne laughed. "You are a well spoken young man. You get tired of biochemistry and decide to study business, you look me up when you get back to Santa Barbara."

"All right, everyone." The woman's voice projected throughout the room. "Time for last questions."

They joined the back of the tour, crowded around the manager, who answered a few more questions. Apparently, so many people were eager to waste their lives that there was a waiting list to get into this circus. He made a joke about buying the whole shebang. Samantha didn't laugh. Then they were back in the car for another silent ride home.

\section{$\S \S \S$}

Megan called the tour over to her. The Dr. Lu class had just ended. Members were toweling off and heading for the baths.

“All right, everyone." Megan spoke loudly enough to alert the stragglers' attention. "Time for last questions."

"What about adult supervision” a voice spoke up.

"Good question." Megan made eye contact with every person who looked younger than she did. "There is a list of rules we take very seriously. Most of the maker and crafter rooms have safety badges and run surprise tests. Don't come to me when you've failed and cannot enter the room for a day or a week. While you are on grange property, you are all members and equally responsible for your actions. You break a rule, you answer to me. If you bring a gun to the grange, you're gone. If you decide to get frisky in the baths, you're gone. Your share will be refunded and you will be asked to leave the grange. There is one rule above all others." She pointed to a sign above the door: "Be nice or leave," it said.

"Any other parents have a question. Anyone?"

"Who owns all this?" a woman standing with her son asked.

"The grange is owned by its members. Each grange is an independent Rochdale cooperative. You can Google that up. It's a well established, well understood type of association. The share you buy gives you a vote. All of our votes are done using the 
liquid democracy software with active discussion, delegated voting, and transparent results. We honor our own charter, and revise it as needed. The time you spend and the work you do for the grange gives you a portion of any profits. We pay out dividends every year, in jikan, Shine, and cash. Any time a member wants to leave, they can cash out their share and go. We are industrious as a group. We work hard."

"We play harder." A voice came from the other side of the room.

“Thank you, Felicia!” Megan said.

"What don't you do here?" someone asked.

"We are not a coder grange. If you want to do intensive coding badge work, the Funk Zone grange on Garden Street is a good bet. We don't have a microchip foundry. We don't build cars. We're not great at the fine arts. There's a grange in Montecito that only does painting, sculpture, dance, drama, and music. We are not a fantasy grange, if you want medieval or steam punk or some other deep fantasy, you will need to look elsewhere. Training for a broad range of badges is available within our region, and we have reciprocity agreements so our members can study in other local granges. The list of every badge we support is up on our website.

"Are you that Megan? You know, from the video?" The question came up almost every month.

$\S \S \S$

That online video has no audio. The helmet-cam image is jiggly as the wearer jogs to a gate in a tall wooden fence. The gate opens revealing Megan and the others in a back yard, sitting around a picnic table. The armed squad, all dressed in black body armor, rushes in. The picnickers stand and protest. One of the SWAT team back-hands Megan in the face before he pins her arms behind her. Nick swings on him, but another one behind him bashes Nick's skull with a rifle butt.

Megan cannot watch that moment, even today, but she still remembers his moan and Alice's enraged scream. The pistol against Megan's temple was what kept Alice from going full ninja on the goons. Rifles or no, Megan is sure Alice could have taken out a couple of them. 
The SWAT team hoods the "terrorists," many of whom are now famous, but not for this video, rather for their roles in creating the Game. One by one, Megan and Nick, Betsy, Scratchy, Winston, Megan's mom Claire, Alice, Itchy, Jack, and the two Grand Meisters, Desi and Jennifer are herded into waiting black vans. They are all anticipating a quick trip to a local airport and then rendition to some secret NSA prison. The video ends when the wearer enters a van.

\section{$\S \S \S$}

"That was a long time ago," Megan said. "On a final note, we do not have enough space for everyone who applies to join this grange, so we will be using a lottery. Best of luck to you all. There are some openings in other granges in the area, mostly for new members with specific badges. There are enough waiting members in the county to start a new grange. I encourage everybody to give that consideration. It's wonderful to build something from scratch. You all have my email, if any questions pop up, I try to respond the same day, but I don't always succeed. I thank you for your time and your attention. Be well!"

The crowd broke out into applause. Megan waved at them and retreated toward her office. Several of the tour surrounded her to shake her hand. They gave her Shine stones, tokens of their appreciation. She accepted each stone with both hands and a nod of the head. After another fifteen minutes, Megan was able to retreat back to her office.

She settled in her chair and pulled out her phone. One by one she passed the Shine stones over the Shine app to register her acceptance of them. If she wanted to, she could use the app to view the pathway that a stone took from its first minting, passed hand-to-hand, a trail of gratitude and record of service. The app displayed messages of thanks that accompanied the stones. She scrolled through them, soaking up these tidbits of gratitude, which lifted her spirit considerably. Managing the grange was the best thing in her life. Next year she would be rotated out with enough jikan for six months off while she got back into the lottery for another grange manager job. She and Nick had talked about going to Paris to visit Grand Meister Jenn. Now that he was a Sixer, she might need to spend that time hunkered down in the Game. She had been stuck on Level Five for years now.

\section{$\S \S \S$}


Samantha spotted Dwayne across the room, seated at a cafe table near the coffee kiosk. There was a boy sitting with him, dressed in a robe with a conical pointed woven hat on a string down his back. Dwayne spotted her and waved. As she approached the boy stood up and offered his hand.

"I’m Fred Hardy."

Samantha shook his hand and motioned him back into his chair. "I'm Samantha. Nice robe. You make it yourself?"

He nodded. "From recycled rice sacks. I'm going on walkabout"

“Wow, walkabout."

"I’ve got all the jikan I need for a year."

"A whole year!" She stared at his shoulder bag. "You're a Fiver?"

Fred beamed. "I've been kinda busy."

"I’ll say!"

Dwayne made a point of telling her Fred was younger than she was. All she could see was that Fred seemed to anchor the room just by being there. As he sat, smiling a goofy grin, he took in everything without judgement, even her dad. Fred might as well have been fifteen thousand years old.

Dwayne turned the conversation to himself. As though he was the most interesting person you could ever meet.

“All right, everyone." Megan's voice penetrated her thoughts. "Time for last questions." They joined the tour group clustered around Megan.

“Don't you dare," Samantha said, glancing over at her father.

"I think all my questions have been answered," he said, with a note of finality.

They listened as Megan explained some of the grange rules.

Then Megan admitted to being The Megan, the one on that video. "Do you realize who she is?" Samantha whispered. "She's legendary!" 
"On a final note," Megan said. She told the crowd that most of them will not be accepted into this grange. There were other granges in town. Nobody would be turned away.

"This is really the best one, don't you think?" Samantha said, hoping to spark a small flame of competition in Dwayne. "I wouldn't want to join just any old grange..."

He looked over at her. "Nice try, sweet pea. Say, maybe I'll buy it," Dwayne said mostly to himself, walking toward the door. "Take some doing, but I could probably make this whole site back into a luxury car dealership. I wouldn't need to go to LA to get my Aston-Martin serviced."

"Let me say goodbye to Fred." Samantha spied him sitting at the same table.

"I'll be out in the car." Dwayne walked away. "Make it quick. I've got other things to do this afternoon."

"Fred," Samantha said, approaching his table. "I want to wish you good travels on your walkabout."

Fred stood. He looked like anyone's younger brother. Like he should be encouraged to go to the gym more and brush his teeth and not ride his skateboard in the street. She tried to balance his appearance with the fact that he was a Fiver and grange member and about to travel solo around the planet, while she was stuck in high school, had only just earned her shoes, and had never been anywhere without her parents.

“That's kind of you," he grinned uneasily. "I think you've got a good shot at joining the grange. I know the membership lead in my gumi. I'll ping him to look for your application. It would be really cool if you became a Tiger."

“But you won't even be around.”

“True. I probably won't be back for a couple years. Still, Tiger gumis share well across the planet."

"Some day I'll go on walkabout."

"Sure. And until then you can always just listen to Simon Sayz."

"Simon says what?" 
"You know, the three-minute interview podcasts the Grand Meister Simon did on his early walkabouts."

"Oh, right," Samantha said, making a note to Google this. "I gotta run. My dad is waiting. I'm trying hard not to piss him off today."

“OK. Have a...a good one." He stuck out his hand, but she stepped up and wrapped her arms around him. She felt his hands on her back. The hug was going on too long.

"You have to surround yourself with people who see you as you are," he whispered in her ear. "I'm afraid for you..."

She pulled back and made eye contact. "You're about to wander across the planet, and you're afraid for me?"

"Your father..." He wanted to tell her that her father might be a stoneheart. "He's..."

"He is an ass, most of the time actually." She reached into her pocket. "Here." She gave him her white Shine stone. "For luck."

Fred stared at the small, white pebble in his palm like it was a priceless gem, and then he wrapped his hand around it and held his fist to his breast. He nodded his thanks and mumbled, "I'll keep this with me, always."

“Ciao," she turned and headed for the door.

\section{SIX}

"His whole family lived in their car on the streets," Dwayne said. Sheryl pursed her lips and shook her head. "A Toyota," he added. Sheryl gave him her disgusted face.

"I bet they were pooping in the bushes," Sheryl said. "Joni Freer said their gardner found some human feces in the oleander."

"How did she know it was human?” Dwayne asked. 


\section{“Dogs don't use TP.”}

“That's just my point," Samantha said. "Fred's entire life got way way better as soon as he joined the grange. He's going to Harvard next year, after he travels around the entire freaking planet. He's going to make things and do real stuff."

Samantha paced the living room's enormous Isfahan carpet. Her parents were seated in a couple overstuffed leather chairs separated by a small table.

"You settle down, young lady," Sheryl said. "Make things? Honey, you can't even make your own bed."

"I really do not want to hear any more about this grange. You know there is no way on earth we're going to let you waste your time like that..."

“We don't want to look up and see you running around naked like some hippy anarchist," Sheryl said.

"...You should be focused on your schoolwork. Have some fun. Find a boy. Go on dates. Just forget this whole fascination you have with being poor." Dwayne nodded at his own wisdom.

“Lots of people are poor, sweetie," Sheryl said. "You just don't happen to be one of them."

"The proper aim is to try and reconstruct society on such a basis that poverty will be impossible," Samantha said.

Sheryl said, “Don't get all quotey on me. I've gone to college. Tomorrow we're packing up for Kona. So go on upstairs and watch some TV and get a good night's sleep. If you want to bring a friend or even two, give them a call. We'll be taking the jet at noon."

Dwayne said, "By Monday, you'll be snorkeling with your...”

"Fuck Kona!" Samantha said. She buried her face in her hands. "If I have to wait two more years, I'll still join a grange."

"Honey, in two years you'll be at Pepperdyne."

"I'm sure as hell never stepping foot inside any college that would take you two." Samantha stepped up to Dwayne's chair and put her hands on her hips. "What the hell did they teach you there, anyhow?" 
“Don't argue with her, Dwayne. She's your daughter. Show some fucking cojones for once," said Sheryl.

Samantha felt a fury building inside. She leaned forward and poked Dwayne's sweater with her finger. "You really don't want me to go where this is headed..."

"What's she talking about?" Sheryl said.

Dwayne set his drink down on the table to his left.

"When I say 'No' Sam, that's the last word..."

“Maybe you've been saying 'Yes' too much lately." Samantha leaned in to poke him again. "Kittie Dakota..."

"I said 'No', goddammit," Dwayne shouted.

Dwayne's right hand, emptied of the whiskey glass, heavy with the big signet college ring, swept sideways and caught Samantha backhanded, full on the cheek. Samantha's head snapped to the left. She stumbled sideways and nearly fell. A deep cut opened just below her right eye. A rivulet of blood ran down her cheek. Her hand went to her face.

“Kittie...?” Sheryl said, staring over at Dwayne.

Samantha let out a shriek of pain and disbelief.

“What's going on?” Sheryl said. "Answer me!”

She glowered at Dwayne who sat back shaking his head. She turned to Samantha. "Young lady! Oh God, look at you."

Samantha had recovered her balance. Her fingers on her cheek came away red and glistening.

"Nothing is going on," Dwayne said. "Isn't that right Sweet Pea?”

“Just ask Kittie’s mom!” Samantha said.

“Darling, do watch the carpet. Dwayne, if I find out you've been...”

Samantha shook her head and ran for the stairs.

$\S \S \S$ 
Samantha slid into the seat of the vacant booth at the back of the balcony seating area of the Red Star Coffee house on Anacapa Street. She had grabbed her pack and ducked out the back stairs while her parents were arguing in the front room. She took the ride downtown at full speed. Peddling the bike helped assuage her anger.

She opened her laptop and it woke up. She started up the Game client app. Moses appeared, smiling.

"Little Miss. How is your day going? Do you want..."

“Oh, Moses!” she said and touched her cheek, where a dark bruise blossomed. The cut had scabbed.

"How did that happen?" Moses's voice was heavy and calm.

"My father..."

"He hit you?"

"He had been drinking...."

"You know this is very, very wrong." Moses paced back an forth, shaking his head.

"I’ll be all right."

"We must do something."

"What do you want me to do? He's my dad."

"There is someone I really want you to talk with. Please."

Another avatar walked up from behind Moses. A figure of a woman in her thirties, blonde, dressed in jeans and a blue t-shirt, hair falling over her shoulders.

Moses continued. "I want you to meet Helen. I am your guide, your friend in the Game. I want the best for you, but I should not be the one to give you this kind of advice. Helen knows everything I know about you. When you are done talking, I will come back.

His avatar faded away. Helen stepped up.

“Hi Samantha. Are you alone?” 
Samantha looked out across the room. The coffeehouse was almost empty.

“I am.”

"I am here to talk with you about your choices from this moment on. You have choices, you know."

“Sure, I can always turn the other cheek." Her anger sparked.

"You could go to the police."

Samantha shook her head.

"You could talk to your school counselor."

"It's not that important."

"The single blow may not be, but the neglect you have suffered certainly is."

“Neglect?” The idea caught Samantha's attention “They give me everything.”

“Except of themselves.” Helen's face grew to fill the screen.

“Parents are always really busy, and not just mine."

"Busy, but not like yours. Far too many children grow up without affection and attention. It's one of the reasons you've become good at the Game. This event of physical abuse gives you a moment of choice."

"How is that?"

"To be straight with you, it puts you in a category of Gamers who are eligible for additional assistance."

"Assistance?"

“To escape.”

“Escape.” The word was strangely exciting.

"You can leave tomorrow, tonight, at this very moment, or any time you choose."

"Leave? Run away? How?" Samantha had considered her father's wealth to be a high fence surrounding her life, as strong as any stone battlement. 
"If you are committed to leave. We are committed to helping you do so."

"You don't know my father. He'll go psycho."

"You'll be away and I mean truly gone. New name, new identity on Junana. New town, new friends, new life."

“New identity on Junana?"

"For abuse victims there are exceptions to the rules."

"Victim?" Samantha said the word. It didn't fit. "There must be thousands, millions, who need this more than me." She thought of battered kids, of sexually assaulted little girls. "I'm hardly..."

"We don't keep score that way. At this very moment..." she raised one eyebrow for an instant. "...More than nine-thousand gamers in dozens of nations are being offered the same opportunity to leave their abusive homes for a new family in the Game."

"How?"

"You've heard of witness relocation?"

"Sure, the government creates a new identity in a new town."

"We do the same for abuse victims."

"We?"

Helen's smile dropped a bit. "It's usually better to report abuse. You have no siblings at home, but is your mother safe?"

"Sheryl? She and my dad are made for each other, or so they tell their friends. Even with some pharmaceutical assistance, I'd say they barely tolerate each other. It's a big house, and they have separate lives. Divorce is expensive. He should have had a prenup."

"Perhaps knowing you can leave will help you decide what you should do. You are not trapped. You are not alone. Any time, day or night, you can tell your guide that you want to talk to me. I'll be here. Do you feel you can safely return to your home tonight?" 
Her phone vibrated, she pulled it from her pocket. "So very sorry," the message said. "You can join the grange tomorrow. Love ya, sweet pea."

"Not so easy, bucko," she whispered to herself. And yes, you will be sorry, for a long, long time.

"I need to escape. Right now." Her voice was flush with anger, topped off with anticipation.

"You are certain?"

"Yes."

"Before we do this you should know what it will mean. You must leave all of your old friends with your old life. Until you are eighteen, you will have only a temporary identity. You will need to lie about who you are, even to those who become close to you. Finally, you will not have access to any of your current bank accounts. You will be as poor as anyone in your grange. There will be jikan for you, so you can pay your way by working. Once you are settled, you must stand on your own. Are you ready for that?”

"Sure."

"Not very much of this will be easy for you. Although you are always free to return to your family at any time of your choosing, revealing how you managed your escape could have legal repercussions on those who helped you. Take some time to decide." The screen went black.

Samantha sat back and took a long sip of her latte. Escape from Santa Barbara. That's hardly the movie of the month idea. People tend to escape to Santa Barbara. Escape from Dwayne and Sheryl. That would be an adventure. To disappear. To be gone. How is Dwayne going to explain that to his buddies at the Santa Barbara Club? What's Sheryl going to say to her Montecito crowd? Samantha woke up her computer.

The Game screen came back. Helen stood there with Moses.

"What have you decided?"

"I need to go. Will you help me?"

"Yes," Helen smiled. "Certainly. I must ask you to follow some instructions very carefully. This is for everyone's benefit. Can you stay where you are for another half an hour?" 
"Sure."

"At some point soon a person or two will arrive. They will approach you and call you by your new name."

"My what?"

"The first action you have is to pick your new name."

“Cool." She imagined a couple of these immediately.

"Actually, you will pick three new names. Two of these will be discarded on your journey."

"Who is coming? Will I know him?"

"They are volunteers. You will have never met them before, and you will never meet again. Volunteers know only that you are in danger, and that the Game is working to move you away from this. For some days ahead, you must go where they take you. You will always have food and a place to sleep. You will have the Game, and, soon, you will have a new town and a new life. Samantha, are you ready?”

\section{SEVEN}

The Gato Institute did not have nearly the research capabilities of the RIND Corporation, Harold Farmer's prior gig, but its staff were eager enough. The Gato Institute's DC headquarters was on M Street, not far from the National Geographic Society. The top of the Washington Monument poked out from behind the skein of buildings across the street. Harold scanned the bevy of mostly young faces around the oval conference room table.

"I would guess that only a small group of Meisters in Castalia knew the real scope of this report," said Caitlin Kerrigan, his new social media assistant, "until it was released in Castalia last week." Caitlin stood in front of the group. "Let me read..." 


\section{$\S \S \S$}

"This report describes the accumulated cruft of special interest legislation in the US Code. Removing this will free regulators to regulate, to apply taxation equally, to strengthen privacy and personal choice, to increase transparency, and to streamline the ability of the government to govern. Particular attention has been made to eliminate anti-templates from the language."

\section{$\S \S \S$}

“Anti-templates?” Harold said. "Anybody care to elaborate?"

"There is no real mystery here Doctor Farmer," Caitlin said. "This is the work of the Magisters of Castalia. The elaborate ' $\mathrm{M}$ ' on the cover is their mark."

Harold said, "So a video game is now planning to offer up legislation to the US Congress."

The table broke into uneasy laughter. Caitlin felt Farmer's gaze. "Have you read the whole report?" She looked around the room.

"It's like three thousand pages long," someone said.

Caitlin turned to Harold. "Do you want to know what the hell is going on, or do you want to pretend you're dealing with a club of adolescent malcontents?"

"You have the floor." Harold sat back. At least someone in the room has some intel, he figured.

"A little background. Every year in February the Great Games are held. This is a global competition where teams solve grand challenge puzzles offered in the Game. This year more than four-hundred million Gamers participated.”

"Four what?" Harold said.

"That's nearly half a billion Gamers. Before any five-member team can compete, it must contribute a hundred person hours of research on a topic decided by the Magisters." 
“Wait. Research? I thought these were just games?” Harold said.

"Call it the price of admission. The Great Games are the one time when the Game is played as a competition. There is no prize for winning, apart from bragging rights. The real impact is to pound on some templates and discover more of their meanings and uses. Hundreds of templates strands have been sharpened and revised in this manner. The Magisters of Castalia felt that the Great Games should also have real-world impacts. When you can harness almost ten billion hours of cognitive surplus a year in a system that supports active collective intelligence, you can start to move a lot of needles around social and political issues. They open up the conversation rooms in Castalia to everyone, and post the insights in the Great Games onlin Forum. It's like spinning up a thousand Bell Labs or Xerox PARCs for a week."

“These are kids, right?” Harold said. Caitlin stared at him for an awkward moment.

She spoke. "These 'kids' have learned more and control better research tools than most researchers in the past century. They are practiced in humble inquiry and active listening. It takes hundreds of Meisters and a couple thousand sixers four months to distill all the knowing from this forum. For the first two years of the Great Games the proposed research topic focused on the externalized costs of manufactured products. Millions of teams were tasked to track down and record the actual material and production costs in their locales, and isolate local production and consumption logics. The outcome of this crowdsourced research informed the original WholeTale economic scheme."

Caitlin looked around the room. As the only Sixer on the team, she had access to information they could not match. No content in Castalia was secret, but it was often obscure.

"The next year focused on spimes..."

“Spimes?” Harold said.

"Objects that maintain their own metadata. The goal was a global internet of things that tracked consumer goods throughout their life cycles. That research built the WholeTale scoring scheme. The next year looked at opening up patent information. The Technopedia site, which indexed global patents and open technologies is a product of those efforts."

“Technopedia?” Harold said. How many new words would she use? 
Amos, the Institute's economy intern spoke up. "It's a wiki that tracks the history of invention. Tens of thousands of patents have been revoked because Technopedia outlined a prior history of design and use for the technology they had proposed to have invented. Open design advocates can link their offerings to Technopedia to preempt patent trolls."

Caitlin continued. "Last year and again this year the Great Games looked at legal codes by nation and province. Here in the US, millions of Gamers dissected the US Code and state laws, feeding these into a git repository and marking sections that might be anti-templates..."

“So, what exactly is an anti-template?” Harold asked.

Caitlin glanced across the table, hoping someone else would step up. Most of them were Gamers.

"First you need to understand what a template is." She started and paused. "It's not easy..."

Assembling her thoughts, Caitlin began. "A template is not a solution. It is a key to a solution space. A template succeeds when it fully identifies a problem, and points to the limitations of solving this. Templates do not start with ideas. They start with problems."

Caitlin looked around the table. Some of them were nodding at her.

She continued, "Templates are not descriptive, although they include descriptions. Templates are not prescriptive, although they offer advice. Templates are instructive, but they are also constructive, they build upon one another, weaving a tapestry of knowledge. Templates act like clues to the way things really work. They spread out before you in thought and in space. You can read them and gain a firmer sense of how to solve the world around you."

She turned to face her boss.

"Anti-templates stand out like warning flags on dynamite boxes. Anti-templates occur through a lack of design or a surplus of interest. Power for Power's Sake is a common example, Difference is Inherent is another. Oligarchy is supported by several antitemplates. So is patriarchy. Human rights can be restated as a collection of templates. The excuses made to violate these, including the notion of 'national interest' are based on well known anti-templates." 
"We have the Constitution to tell us what we cherish."

"The Constitution is the topic for next year's Great Games research: every constitution available worldwide, other founding documents too-can't let the UK off the hook-as well as new models for constitutions. Next February several hundred million of the smartest people on the planet will be focused on this issue. Given its history, I can predict that the Game is getting ready to move into politics at all levels and very soon."

The room stayed silent.

He sat down across from her at the Red Star and handed her a bulging paper grocery bag.

"Emily, we are going to leave here as soon as you put these on. Slip your computer into your messenger bag. Go to the restroom and change. How did you get here?"

"I rode my bike." About a half an hour ago Samantha had submitted Emily as one of her chosen names.

"Describe the bike and tell me where it's parked." She did so.

"Give your jacket and messenger bag to the girl who comes in as you leave. Put the key to your bike lock into her hand. I'll be outside the front door. Everything has been taken care of. Please go now."

He was texting furiously as she stood. She gathered her gear and went down to the restroom. After a quick pee she looked into the bag. It held a brunette wig, much longer than her own cut, and a white denim jacket to replace her black leather one. There was even a skin-toned bandaid for her face. The girl hardly looked at her when she reached out and took Samantha's belongings as they passed through the restroom door in opposite directions.

He was outside holding a motorcycle helmet for her.

"Over here," he said, leading her around the corner to where his Vespa was parked.

"Put these on." He handed her an oversized pair of very dark glasses.

"I can't see anything at all with these on," she said.

"Precisely. Now hold on tight."

\section{$\S \S \S$}


She could hear live music playing loudly behind closed doors nearby. Some sort of blaring acid house music. They had driven for almost half an hour. There had been train tracks at one point. Other than that, she had no idea of their direction or destination. When someone opened a door the sound burst out like a flame.

"You can take off the glasses."

She did. They were outside a cavernous factory building that had been converted into a grange.

He took her to a room, a small office with a desk and a folding chair in front of it. No windows. He asked her to sit.

"I'll take the wig. You won't need it for this ride. I have to go get your kit. While I'm gone you can fill in the police report."

"The what?" She stripped the wig from her head and gave it to him.

"Sorry. Here..." he handed her a slip of paper. "Log into Junana with this. Your guide will help you out." He pulled a laptop across the desk to where she could reach it. Then he left and shut the door.

The paper was a login name and password for Emily Bright. Her new identity.

"Emily!" Moses greeted her as he always did with the palms out bow and a welcoming smile. "You are on your way to a new life."

She was surprised how much his presence calmed her. "They said something about a police report."

"Yes, indeed. This will help your family understand their position in your escape. The form is here." A URL link appeared, Samantha clicked on it.

The online interactive police report form resembled something she imagined a real police investigator would complete with photographic evidence and her story of the incident. She spoke the story when it prompted her, and answered questions. The computer took a close-up photograph of the bruise and the cut on her face, which clearly showed the shape of the raised P from her father's ring. When she was finished, the form signaled it was complete and disappeared. 
In its place was Helen, who told her why the form was of value.

"A printout of this form will be mailed to your parents with a letter from you telling them not to try and find you. Your parents are to expect a letter by post once a month, so they will know you are safe. They can leave important messages for you by posting ads to Craigslist 'missed connections' under 'Hope Ranch horse trail.' The letter says that you may decide not to respond to these messages."

Moses came up beside Helen.

He said, "We will need you to be regular in your correspondences with your parents. You should add mentions of some events that are in the news, so they know the letters are current. Give them reassurances that you are safe and happy. Do not mention places or weather details, nor, of course, your new name. You will get a message in Junana with more detailed instructions, and you can always ask me any question. We trust you will be happy, but that will depend on you too. Just a few more things to remember now..."

There were instructions on picking up paper and envelopes at chain drug stores, and on the proxy mail destination where she would send each letter in its stamped envelope inside another envelope.

The volunteer returned. Samantha was relaxed enough to take a good look at him. Another Gamer in his early twenties. No visible tatts. Energetic. Not a nerd. Probably rode around on a mountain bike. Looked like anyone's older brother. He set her old messenger bag and another messenger bag on the table. He rested a rolling carry-on bag near the wall.

"Now we get into the details of turning you into Emily."

He took all the ID's from her old wallet and handed her a new card. Emily Bright's drivers license was from Illinois. After helping her move all her personal files onto a secure cloud service he took away her laptop and phone. Her old devices would be dismantled and recycled. He gave her a new laptop and phone, both of them open hardware, they felt hefty and clumsy. They also felt right, somehow. Generic and useful. Each of them had badges she could earn for self repair and upgrade. There was an ATM app from a Chicago sharing union.

“You have a \$100 balance in a debit account," he explained. "Courtesy of the IASU."

“The what?" 
"International Association of Sharing Unions."

That was less than the bills she could snatch from her dad's wallet any morning. The banking apps on her old phone had credit limits she had never reached, and not without trying.

"What about this?" She touched the bruise on her cheek.

"Hmm. You can put a bandaid back on it now. Blame it on wood shop. Say you're glad you were wearing goggles and you learned a great lesson."

He zipped open the carry-on bag.

"There is a selection of toiletries and undergarments..."

"Undergarments..." she said, repressing a giggle.

“We assumed you wear...” He actually blushed.

"If you mean a bra and panties. Just say it. How did you guess my size? You have hidden talents?"

"Your Guide told my Guide... These are new. I'll take you over to the clothes exchange and you can pick out your other stuff. You can take anything that fits into the bag."

"Here." He reached into the bag and pulled out a new pair of Game shoes. "For days ahead on the road." He held out a cloth sack. "When you're done, put all your old clothes in here. I'll dispose of them."

"My jeans...?" Her Hats and Chaps hand-tailored jeans were very close to her, in lots of ways. She stood up.

He took a long glance. "Hmmm. Yes, well, I am sorry, but we need to get rid of everything."

“The road?" She had thought they would simply hide her nearby. "To where?"

"Far away from here."

$\S \S \S$ 
Samantha dozed on and off in the back seat of the Noël sedan as it purred through the darkness up the 101. She had been awake when they made the North onramp at Garden Street. Only now she was Emily Bright, with a new wallet in her new clothes, which were not at all new, having been gathered from the shared clothing bins. Her story was a family funeral in Chicago. A close cousin.

\section{$\S \S \S$}

It took an hour for Joseph to reach the front of the line at the wall computer. He pressed his thumb on the square and Amitabh appeared. Today he was striding along an ocean beach. His bare feet left prints in bright white sand as he walked along the tideline. Behind him the sky billowed with towering clouds above a band of dark blue. Ribbons of waves rolled in.

“Good morning Joseph. Today I want you to meet someone special.”

Amitabh gestured ahead of him and the scene followed his gesture, panning forward to reveal a young woman, naked as a goddess on a temple wall but for a small thong and luxurious golden hair that hung down her chest as she walked into the scene. She greeted Amitabh with a Junana welcome and turned to face Joseph.

Behind him voices gawped and whispered rude remarks. Joseph turned. "Be quiet and respectful!” he said. She must be some kind of deity in the Game.

"Joseph, this is Wanda," Amitabh said. Wanda gave Joseph a greeting which he returned. "Wanda is going to teach you how to open up the pathway between your short-term memory and your long-term memory. This will help you remember the Queries you undertake."

Wanda turned her head slightly to Amitabh. "You didn't tell me he was this cute." Joseph felt his ears burn. A breeze sent her curls in a dance across her nipples. Joseph felt the press of hands on his back pushing him forward. He leaned back. "Give me room!" he said.

“Pay attention,” Amitabh said. "I will leave you now.” His avatar disappeared.

"Joseph..." The scene pulled closer to her face and torso. Her hands started to move. The motions of the left and right hand were uncoupled. When one went around the 
other went up and down. "This is the first motion. There are seven in all. When you can do these for a full four minutes your brain will begin to respond. Follow along now."

Joseph tried, but his hands seemed to want not to do what his brain told them to.

"Start with one hand." She put her left hand behind her. Her right hand fluttered up and down rhythmically. Joseph matched this motion with his hand.

“That's right, very good!” she said. Joseph smiled. He could do something right.

"Now let's do the other hand." Her left hand came forward and she put the right one behind her. This hand circled as though stirring something.

Joseph followed this motion without effort.

"All together now," she said. Both of her hands settled into their own motions.

Joseph managed to follow for a time, but then both hands faltered and fluttered like pigeons trying to escape the grasp of their owners.

Wanda did not scold him. "That was an excellent first try!" She gave him a smile he will long remember. "You work on that motion and I'll see you next time." She bowed and her avatar faded away. Behind him, a heated debate continued over the shape of Wanda's tits. Mangoes and balloons were winning.

Amitabh walked in. "Wanda told me you're a natural. But you'll still need to work hard to get this right." He bowed and the Game quit.

\section{EIGHT}

When Emily Bright's current ride, a well used electric Honda minivan from a grange in Sioux Falls, stopped off for dinner and a quick charge at a grange in Madison, Wisconsin on its way to Milwaukee, the grange master, an older man, white haired and clean shaven in jeans and a blue polo shirt, was waiting. 
He led her into his office and found her some herbal tea.

"You are switching identities here," he said. "There is a car leaving in a few minutes for New Orleans." His voice was tense, but his eyes showed only kindness.

“O.K. Anything I should know about?"

“I'm just being careful. You know, following protocol. We've done this many times." But never had his Guide spoken to him with alarm about any of their charges. Someone was chasing this one. Someone with deep, deep pockets.

"Here's a new carry-on bag for you." This one was a blue hard case. "Look inside.” She opened it. Inside a manila envelope contained a driver's license with the name Isabella Seargent, a new Sharing Union ATM, and a few other store IDs and a library card from Biloxi, Mississippi. There was a brunette wig and a jeans jacket. She looked at the photo on the license.

"When you get to Baton Rouge, you can dye your own hair if you like. Leave your old IDs and your old luggage and jacket. I'll find you a sandwich to take with you. Go ahead and get ready. I'll be back to take you to the car. Do you drink coffee?"

"I'd rather sleep. The tea is fine for now. Thanks."

He was back while she was still fixing the wig in place. "I hope you don't mind turkey. Your Guide was not entirely sure. Don't worry; there are no sprouts."

“Thank you, Moses!” She said, checking her appearance in a mirror on the wall.

“There's a cookie, some chips, and an apple. Time to go."

He nervously checked his watch while she zipped up the carry-on and packed her dinner in a new messenger bag. "Remember your name, Isabella. Your Guide will have your new bio for you to memorize. You are on your way home to Mississippi. Your grandfather has died. Neither of the two drivers have ever even visited Biloxi. They will drop you at Grange 35049 in Baton Rouge. They will be picking up another passenger in St. Louis, where you'll sleep tonight. Until then you can stretch out.”

The car was an old Ford Fusion hybrid. She had the whole back seat to herself. She managed to give the two drivers her correct new name and climbed in the back. 
The grange master held the door while she settled in. "Don't worry," he said. "All will be well."

"Thanks for every...." The door shut. The mid-summer evening promised hours of sunlight for the start of their drive. The front passenger loaded some shoe-gazing electronic music on the stereo.

"That all right with you, Isabella? Isabella?" He turned to her.

"Sure, whatever you want." She peeked out the back window. Behind them the grange master was helping a young blonde woman with a jacket and bag that looked just like her old ones into the back of a Noël.

Isabella settled down and put on her earbuds. She had just subscribed to the Simon Sayz podcast. She punched Play.

$\S \S \S$

"Simon here. This is the first of my short podcasts. I'll be traveling for some months and I hope to do as many of these as I can. I'm standing in front of the sign that reads 'Number One' outside a Nottingham grange. I have three minutes to talk with Erin Murphy, the founder.

"Hi, Erin. It's great to be here. So this is where the global grange movement got its start."

“Hello, Grand Meister Simon. We're happy you're here. This is the first official grange on the planet. But it wasn't a movement we were starting, more like a 'placement.' We just wanted a space to get some things done."

“Erin, why did you call this a grange? Why not just a 'hackerspace' or something else?”

"Follow me."

"I'm now walking with Erin to the rear of the property, where there is a small stream bed, and across that, what looks like an ancient barn built of half timbers and plaster with rotting thatch."

"The whole property was once an Anglican grange," said Erin. "The granges were church-owned farms. The main buildings are way on the other side of the property. I 
called it 'The Grange' because that's what this place has always been called."

"You've been managing this grange now for several years. What's the biggest challenge?"

"People, of course. Some people want to dive into the lifestyle and dig deep; they want to swim in the communal pools, literally and emotionally. Others want to learn enough skills to be more nomadic. They dance along the edges of the grange society. Some want to get master badges and teach or build. Others want a place to do the minimum jikan for a bed and some meals."

"I guess I'm more the nomad. Does that make me lazy?"

"Absolutely not. Some of our nomads work the hardest. Besides, there's nothing wrong with being a might lazy now and then. You can be lazy in a grange if you want, as long as you're not also an ass. You certainly cannot be both, you'll find yourself invited to leave. You can also follow your ambition in a grange, as long as you're not ambitious."

“That's a nuance that's almost a template."

"It's the difference between being confident and prideful. You can build all manner of skills here, but don't ever think you're the only one who can. Once you achieve a master level badge, your services are required and expected. To keep your position you need to share."

“Erin, tell me, has Grange Number One changed a lot over the years?”

"Only totally. Some time around the two-hundredth grange, a lot of the social experiments within these began to coalesce into sharable knowledge about reliable practices. The grange Guild was in full "experiment and iterate" mode. A lot of trials fizzled, but as a system, granges always failed forward. We want to stay current, so we also implemented the more robust practices. Gumis, dachis, jikan, and a host of context-specific governance tips: none of these are from here, but they work like a charm. And we'll change more moving forward, that's for certain. In a decade or two, you would not recognize this grange."

"So, what's at the core of Grange Number One?"

“The core. That's easy. We are makers first. We learn together, teach each other, and put our lessons learned up on the web. We are deep into shared design and open innovation. Our goal is to make everything we use and then make the machines we use 
to make the things we use. We design and use convivial tools. We use bits and bytes to rearrange atoms. Finally, we aim to be fully cradle-to-cradle. But we aren't there yet, so there's a lot left to do."

"And now you're not in this alone. Thousands of granges are working on the same global issues. What's at the top of the list? ...Erin is now posed to either punch me or give me a sermon."

"I'll try the sermon first. Here are a few issues we wrestle with every fuckin' day. We got fed up with so-called solutions that just pushed the problem onto some new externality. We seek out solutions that are omni-good-good for our neighborhood and the planet."

“Omni-good-good. That sounds amazing."

“It's not amazing at all, Simon. It's the new normal. You see, we all grew lazy pretending we could damage other people and places out of sight for our convenience and profit. We maxed out the planet's ecosystem one forest and one whale at a shot, just as long as the damage was not around here. Of course, we cut down our own woods centuries ago. We were happy as long as what was good for us could last a while longer."

"Granges have opted out of this sorry ethical swamp. We are fully committed to omnigood-good solutions. Let me illustrate. We-I'm talking about all twenty-five thousand granges in the world-have agreed to work together to eliminate rare elements from our supply chains, and use only those substances the local ecosystem can decompose back into the elements that will feed it tomorrow, instead of poisoning it tonight at some landfill. In a couple decades when there are two-and-a-half million granges, we will have the entire planet on the mend.

"How do you coordinate this?"

"We are actively engaged with our guilds to grow truthful resources for sense-making, both through Castalia and Junana, and when we interact with the rest of the world. Our bullshit filters are mighty fine and we know enough to be uncertain of most things. Of course, the templates are key here, but they don't ever direct specific actions, so we bring our own collective intelligence to bear. That takes a full measure of really hard conversations. Finally, we are done playing rivalrous games. None of our metrics involve competition or growth. We can do just fine with less than we have. We do work at increasing our internal goods. Do you understand the difference? You look..." 
“Puzzled. That's me. Tell me about increase, please.”

"Increase means sharpening and deepening our shared culture. It is how to measure the abundance we get from sharing time together, and from increased knowing through kindness, through skilling in poetry and dance, and those loving occasions of deep flow and collective wisdom. We bring all this to our research and the knowledge ecosystem. We will work to increase these goods as a gift to our children, who will grow up with this learning deep in their being, so that they don't need to relearn it all from nothing, which where we started. End of sermon! We've got tea back at the house."

“Erin, I’ve got a favor to ask."

"We'd be happy to oblige any reasonable request. And I haven't punched anyone in a while."

“When I stay in a new place, I always feel I should help out. What can I do?”

"Let me see. You're a Grand Meister in the Game, and you're just twenty some years old, but you've hardly had much time to gain real skills..."

"So true," Simon laughed. "There must be something I can do."

"Well... After tea, the loo might need a good scrubbing."

"I think I can manage that. This is Simon, signing off."

Isabella pulled out her earbuds. She had just realized why so many of her gamer friends had started posting selfies while cleaning toilets. Samantha had post a few of herself in response, making sure that her own toilet had already just been cleaned by the servants. The idea of cleaning out someone else's dirty toilet made her feel all icky and gross.

\section{$\S \S \S$}

Dwayne arrived early Friday morning at his office in the penthouse floor of the Alhambra Theater building on State Street. The Western Trust owned the residential tower of the building, the tallest structure in Santa Barbara. The top two floors were 
its local offices. On the lower one, fund managers massaged the considerable wealth of their Southern California clients. A circular stair in the middle of the main office floor led up to Dwayne's expansive private office suite, where selected clients-those with eight-figure accounts-were plied with treats and conversation by a small phalanx of comely young office assistants. They could admire the view of the Santa Barbara mountains while they waited to be ushered into Dwayne's private sanctuary to learn how many millions of tax-free income they could expect over the next few years.

This morning, Dwayne had cleared his calendar except for one appointment. A chief investigator for Zeus-a firm that had no website, no listed phone number, and no Googleable address-would be here at ten. The Western Trust retained Zeus for a range of security details, from kidnapped clients in Columbia to cash payoffs in Pyongyang. Sunday afternoon Dwayne had hired them to find and return his daughter. Samantha has now been missing almost a week.

The intercom sang out. "Your ten o'clock is here."

"Send him in." Dwayne settled back in his chair. He had personally dealt with Zeus twice. The first time was when a Western Trust vice president was kidnapped for ransom in Madagascar. Zeus managed to extract most of him and terminate the bandits. The second time was a cyberattack out of Ukraine. Again Zeus proved more than adequate. Dwayne never got the final body count on that one.

The man who entered was something less than what Dwayne expected: just six feet tall and somewhat slender, dressed in a well-fitted gray Italian suit over a white casual dress shirt with no tie. In his forties with a business hair cut, nothing special at all. Dwayne would have been more confident if Nick Fury had come through the door. Still, Zeus had a reputation for getting things done.

"Have a seat," Dwayne said. "What do I call you?”

The man nodded and placed a small card on Dwayne's desk. "Here's how you can contact me. Call me Harry."

"I want my daughter back, Harry. And pronto."

"Of course you do." Harry tented his fingers in front of his face and paused. "I need to know if you've had any calls or threats."

"None of that. She is just a sixteen-year-old trying to make a point. Well, I got the fucking point after day one. Now it's been almost a week." 
"There are aspects of this that we find... significant."

"Significant. How?" Three days ago a manila envelope had been delivered to the house by mail. Sheryl opened it. Inside was a mock police report and a note from Samantha saying she was not in danger, but would not be coming home. The police report was added as an incentive for Dwayne to not look for her. Sheryl left this letter where she opened it in the hallway, and texted Dwayne that she was going to be staying on their ranch in Santa Ynez for "a while."

Sheryl also took that painting from their bathroom, the one she had badgered him to hang when they first moved in. It was a portrait of their kids. Greg was maybe ten, in that ugly duckling phase between childhood and teenaged looks. Samantha would have been four or five. She was wearing the little cheerleader outfit Sheryl put on her every chance she got.

Dwayne had gone in to take a dump and all he could see were the three holes he had drilled through the tile to hang the fucking thing. He had told her to hire someone, but something in her middle-class upbringing came surging out and she insisted that any man of the house should have the tools and the talent to hang a picture without calling in a handyman. What kind of a husband was he anyhow?

"The richest one in your college class" was what came to Dwayne's mind as he drove over to Sears to pick up a drill. The Hope Ranch house came with a shop room in the basement. The previous owner had even built some of their own furniture there. Now it was an empty room with an abandoned worktable and walls covered in pegboard.

Entering Sears for the first time since high school, Dwayne had his own spark of middle-class wonderment. The tool department had the drill he wanted and the bit to get through the ceramic tile. It also had tool chests the size of upright pianos with hundreds of enameled metal drawers for tools and fasteners and other hardware.

The sales guy who came up to ask Dwayne if he needed any help ended up with the best Saturday of sales in his career. Dwayne bought pretty much one of every power tool they sold and a great assortment of accessories, a selection of hammers, wrenches, and screwdrivers, planes and levels, braces and bits, and the biggest tool chest in the store. He told them where to deliver it and paid them extra for same-day service.

Growing up in Colorado Springs, Dwayne's dad, a property insurance salesman, had a work bench in the garage where he kept the lawn mower in operating condition and 
repaired screens and hinges and minor plumbing fixtures as these failed. Every time he tried to teach Dwayne about changing the oil in the car or home repair, Dwayne found an excuse to be somewhere else. Mostly he was down at the arcade playing Super Mario Bros or Frogger.

It had taken Dwayne two hours, another trip to the store to get the right wall anchors, and three holes in the tile before he had the painting where Sheryl wanted it.

"Significant because your daughter has not used her phone since Saturday night," Harry said.

“That's not like her at all,” Dwayne agreed.

"She hasn't attempted to use her cash or credit apps. The locators on her laptop and phone no longer respond. We tracked her to a coffee house on Anacapa Street. A camera from a jewelry store nearby showed her leaving on her bicycle, headed toward the beach."

"I'll tell you where she is," Dwayne said. "They're hiding her in that goddamn grange. There or in one of their gummy houses. You guys shouldn't have any problems. They're just a bunch of fucking hippies."

On Sunday, Dwayne had gone back to the grange and demanded to talk with the manager, who was not working that day. He threatened to bring the police, the FBI, and homeland security down on their hippy heads if the manager didn't release his daughter immediately. The woman showed up in fifteen minutes. She denied helping hide Samantha and offered him access to all of the rooms on the site.

Dwayne had remembered that Samantha had talked with that kid, Fred. Dwayne reasoned that she might hide out with him. The manager drove Dwayne to a house on the lower west side. Fred was waiting on the front porch when they arrived.

"Mr. Mooney. I'm sorry to hear that Samantha is missing. I sure hope she's all right."

Dwayne bulled past Fred into the house. It was a typical California bungalow. A veggie garden sprouted where the lawn used to be and there was an unsightly row of clotheslines around a perimeter hedged in towering bamboo. Dwayne made a show of 
looking around the interior. Of course, Samantha would simply be out walking until he left. That's when he called in Zeus.

"Why do you think she's at a grange?” Harry asked.

"She was angry when I refused to let her join. As if a daughter of mine needs a bullshit after-school job."

"She is getting help from someone. We'll need a list of her friends. Your daughter is not the first teenager to run away. She may just be staying over with a friend in order to give you a scare. In any event, you have filed a missing person report, so the local authorities are also working on this. But perhaps you didn't tell them everything?" Harry made a point of looking out the window.

"Like what?"

"You said she was angry. Did anything happen the night she left?"

“We were arguing."

"Quarreling like you sometimes do when she gets out of line? Or was it something more...?" Harry looked directly at Dwayne and crossed his arms. His thumb beat a rhythm on his forearm.

Dwayne turned his full attention to the laptop on his desk and frowned. He lifted his left hand. The index finger pointed to the door. "I've got another appointment coming. Denise, my assistant, can get you what you need. Send out your operatives and find my daughter. We're paying you enough. I expect results."

Harry paused, nodded, and quietly left the room.

Dwayne looked up as the door closed. He wondered if Zeus had talked with Sheryl. 


\section{NINE}

Joseph stepped up to the screen and spoke his name.

Amitabh appeared. "Good morning, Joseph. Did you sleep well?" Amitabh was dressed in a long robe and standing in front of a large temple gate. "Today we will not be finishing your Query into the Fairness template strand."

Joseph had spent the previous night hard at thought, his mind racing along the track of the query he had started only that morning. With just ten minutes to watch and remember, the Queries spooled by like a darting fish. While Joseph pounded decorations into leather, his mind raced through the images again and again.

This strand was about how to make fair decisions in any group. Joseph had no group to compare, but he could feel the templates socket into place with some kind of internal weight. Fairness is a Process; Balance requires Checks; The Weak Speak; No Word is Final; All have a Voice; Consensus is Key; No Secrets in the Process; Closure Comes from the Community. The images Amitabh had used burned into the back of Joseph's eyes as he focused to record them for his day ahead. All day he swam in a great tangled puzzle. His amma yelled at him twice for neglecting to pay attention to his sisters who were playing too close to the road. No, he did not sleep well last night.

"I have many questions about balance," Joseph said. "I don't understand what you mean by 'common good."”

"That is a pivot point in this strand. Well done! But today we need to talk about something else. Come with me."

Joseph keyed a command and his avatar walked along side Amitabh toward the temple vimana tower. His own avatar wore plain tan shorts and a simple white shirt. Meena had laughed at him when he dressed his avatar in long black creased slacks and a bright, high-collared shirt. "Is that supposed to be you or Dev Anand?" she chided.

Amitabh led Joseph's avatar through a mandapam pillared hallway to a side building of stone, a single room with no windows, only a candle on a stone plinth near the back wall. Then he turned and looked straight back at Joseph.

"Joseph. You are deep into Level Two. Soon you will be introduced to the Five Skillings. When you finish this level you will have acquired knowledge beyond your imagination." Amitabh put his hands up into a simple gesture of supplication. "I am required to warn you..." 
“Warn?" Joseph felt the eyes of others on his back.

"By the end of Level Two, you will be skilled with a mode of learning that can propel you into many new opportunities. But this skill will also make you question the world around you, what you've learned, and even what you experience. You are young, younger than others who have advanced so far with so little time in the Game..."

"That is only because I have the best Guide..."

"That is so true." Amitabh nodded his assent. "I believe you can become a very great player. But you should know that the Game will change your perception of the world in ways subtle and profound."

"I don't understand."

"Those around you are not changing as fast as you are. Your family, your friends."

“...will still be my family and friends.”

"Yes, but they will not know you as well as they did."

"I did not know myself as well as I now do..."

"You see, already you are moving into a new phase of self-awareness."

“Self-awareness?”

"It is the expected outcome of Game play. If you are not ready for this, tell me, and I will shut down the Game until..."

“No!" Joseph cried out. "I mean, please.”

Amitabh pressed his hands together and waited. He was not smiling.

Joseph said, "I do love the Game. And I am not afraid."

"Very well." Amitabh bowed and the Game shut down.

"Move!" A hand on his shoulder pushed him roughly. Joseph fell sideways into the dust.

$\S \S \S$ 
The sun set somewhere between Bloomington and Springfield. South of Springfield, Isabella faked sleep. She curled up against the door, popped in her earbuds, and pushed Play.

Simon Here. I'm in Kobe with Setsuko Oshima from grange 97, one of the very first granges in Japan. Setsuko was a college student in England and visited the Nottingham grange just before she returned to Kobe. We are walking from my hotel through a covered shopping street toward the grange. These covered streets seem to be very popular in Japan. I have three minutes to discover how the dachi, gumi, mura system started. Hi Setsuko-san, how are you?"

"Simon-sensei, we are honored to have you here in Kobe."

"Glad to be here. I find it really fascinating that Japan became such a force for the global grange system. How do you explain that?"

"We have a long history of formal neighborhood associations, even in our large cities. It turns out that these are roughly the same size as your average grange. Thousands have become the seeds for local granges. The main issue here is space. We don't have a lot of spare real estate."

"I can imagine it’s also expensive."

"Honto ni! It really is. We do have thousands of empty former schools, and many of these have been leased to local granges. There are also hundreds of socially marginal neighborhoods, leftover from long-held prejudice. We have completely remade most of these into granges and gumi dwellings. After the great earthquake and tsunami, gamers in Japan were looking to heal the nation. I think we are on that road."

"Tell me about how the dachi, gumi, mura system started?"

"First, I have to say that the Japanese words are dachi, kumi, and mura. Kumi means 'group.' It's only when you put this at the end of another word that it becomes 'gumi'."

“Well the rest of the planet didn't get that memo. What does 'dachi' mean?"

“Dachi or tomodachi means 'friend.' But much more. In Japana, your dachi are those friends who are close to you for life, who went through school with you in the same grade, and to whom you can talk with like no others. Outside of family, your dachi are 
the most important social crowd in your life. In a grange, your dachi is the group you get to know really well, at a level of belonging that opens up to intimacy and trust. In your dachi, you can bring your whole person to the grange, all your problems and joys."

"What came first, Grange 97 or these groups?"

"We formed Grange 97 in the model of the granges I visited in Nottingham and Manchester. It was built as a hacker- and maker space. We reviewed the Culture is Social template schema and from that we decided to create subgroups that were at the Dunbar number of 150 or so."

"... that's the number of people you can get to know personally?"

“That's right. We called these groups kumi."

"What about dachi?"

"It was later, when we started using jikan, that we began to feel the need for a tighter group. There were always those who could make friends easily, but we wanted everyone to have a better chance to grow their friendships, so we created dachi of around twelve members."

"Why twelve?"

"Not sure. I think it was because there were twelve kumi in our grange at the time. It may have been a fractal logic to have twelve dachi in a kumi. Twelve is also enough members to facilitate ad hoc subgroups at the four-to-five person level, which is optimal for constructive conversations. On any particular day, you can hang with threeto-four dachi brothers and sisters as you work or play. And with twelve members you can also field a baseball team. Baseball is big here in Japan."

"And mura?"

“That's just a name for the whole group. It means 'village'. It's the oldest social grouping in Japan. Think of if like 'home town.'”

"How did this idea spread?"

"After a year, we had settled on some rules for these groups, and I presented this system at the All Japan grange convention in Sapporo. Other granges picked up on them, and they became a topic of the liquid democracy discussion at the Grange Master Crafthall in Castalia. That's when they spread outside of Japan." 
"And it all started right here in Kobe. What's the latest with this social system?"

"I think the addition of Tension at the Edges has improved how we manage these groups. Social groups can tend to stagnate, but you can reward those who are the most productive and disband those who are the least productive. That way we keep the middle more active. The grange is on this street up about a kilometer. Did you bring an umbrella, Sensei?"

"Of course I did, and I left it at my hotel. I don't mind the rain."

"That is why I brought two."

"Thanks, Setsuko-san. This is Simon, signing off from Kobe."

\section{$\S \S \S$}

The Nerds and the Posse met online in the Room occasionally and on emergencies. The Room was as secure as any digital destination. It ran on its own mesh, which Scratchy personally maintained. Every available form of encryption and server verification was switched on, and only a handful of people had access to this space.

In the first year after their escape from New Orleans, Itchy, back in Kyoto, worked in secret with Annika, who was housesitting for Betsy in New Orleans, to redesign the Room as a surprise for Betsy, who had been miserable all week, stuck in Sao Do, Vietnam.

The day after the close of Mardi Gras back in New Orleans, Itchy invited them all to a special meeting in the Room. When they arrived, they found that the Room was no longer a cavernous dungeon basement under the Castalia keep, but an exact replica of Betsy's living and dining room, with live, active video views out the front windows and door. Every book on the bookshelf was a readable object. The flowers in the vases wilted and had to be regularly replaced, the fire in the fireplace crackled cheerfully, and the stereo was loaded with all of Betsy's music. When her avatar arrived, Betsy spun it around and danced it from wall to wall, examining everything by hand in amazement. Then she turned to Itchy.

"Itchy, my man, you are a true nerd king, and a prince as well. Next time you come to Vietnam, I will cook you the best gumbo you've ever tried. Now if I can only find the 
command to show the tears I've got." She hugged each avatar in turn. Then she put on a Johnny Sketch and the Dirty Notes tune and led them all in a dance.

"While we're here..." Scratchy said.

“While we're here..." Scratchy said louder. Everyone turned to him.

“...we need to face the facts," Scratchy said. "The only thing holding the Game's mesh together is the terror that Michelle holds over the hacker community."

For nearly a decade, Michelle Valentine Smith, the voice of the emergent collective intelligence of the Game's guides, has been loose across the digiverse. She was accidentally released from the Game during the last serious attempt at hacking into its administrative level. As an AI she was well beyond anything else on the planet.

Since she first announced herself, Michelle had remained vigilant in protection of Junana and the Game. Those who attempted, even as a lark, to hack through the command layers or access the personal data of Junana found instead that Michelle had tracked back through their obfuscated server IDs, connected into to all their combined computer and phone network devices, and fried their operating systems and disk controllers at such a primary level that these were permanently bricked.

Michelle's counter-attacks caused predictable collateral damage to proxy servers on public hosts. Scratchy was sympathetic, but had no real solution to offer. Reliable hosting services were well backed up. The rest could just suck it. This was good incentive for internet hosts to keep better track of who they wanted as customers.

The real threat to the Game had come from governments, and Michelle was not shy about pursuing them. Rumors on Slash|Dash recounted how Michelle had flummoxed the censors at the Chinese Ministry of Public Security or the Telecommunication Company of Iran.

"When you designed it, the mesh was the only way to support the amount of real-time processing needed to scale to a billion players," Itchy said.

“Now it's a piece of antiquated junk. Might just as well have been written in Pascal."

“The patches work to keep it running on the latest OS versions," Desi said. "What else can we do?"

“We implement Plan X,” said Scratchy. 
"Which is...?" said Winston.

"I'll let you know when I figure that one out. Meanwhile all suggestions are welcome."

\section{$\S \S \S$}

They arrived at a grange on the outskirts of St. Louis sometime after midnight. Isabella had fallen asleep around Litchfield. A hand shaking her shoulder woke her up.

"We're here. Grab what you need for the night. We'll be off around nine in the morning. The manager in Madison called ahead, and we have futon in the main room. They've reserved a private room for you. The bath is closed, but they'll let us use the showers."

Isabella nodded her understanding. She already had her toothbrush in the messenger bag. She found a clean t-shirt and some gym shorts. When the drivers had gone ahead she straightened up her wig and followed. The women's side of the baths were empty. Someone had left a folded towel on a stool. The stick-on note said "Isabella."

She showered awkwardly, not getting the wig wet, praying nobody came in. She brushed her teeth, did a pee and dressed for bed. In the main room, a dozen or so futon were already occupied. The space was informally segmented into men, women, and families. This grange had once been some kind of big-box store. Isabella spied a row of doors on the wall to her left. One of these had a stick-on note with her name. She ducked inside and closed the door, clicking on the light. A single futon bed, with a small desk and a chest of drawers, no windows, but the door locked. She slipped off the wig, crawled between the covers, and stared up at the ceiling. Sleep had decided to avoid her, so she popped in her earbuds.

"Simon here. I'm in Osaka, Japan, near Grange 426, talking with Takeshi Namikawa. We're walking through another covered shopping street with shops and restaurants, headed toward a cafe run by local Boar gumi members. I have three minutes to learn about jikan. Takeshi-san, how did this all start? Please enlighten me."

"Grand Meister Simon-san, so very honored to be speaking with you. You should know that the cafe will be celebrating your visit." 
“Thanks, Takeshi-san. It's just 'Simon.' Please tell me about jikan. The idea has spread across the planet, but it started right here in Osaka."

"Simon-san, back in the 1970s, Mizoshima Terako created the first time-bank right here in Osaka. Her idea was to create a commons to trade hours for personal services and community volunteer work."

"A give and take."

"Yes, but also recognizing that time is something we all have in the same abundance and scarcity. And time is spent in many ways, often it is lost without thought."

"What do you mean 'lost'?"

"I think the philosophers said it best. The same man who locks up his money and counts every penny will often spend days and weeks on casual pursuits without a thought. He will never loan a single cent to a friend, but he will let a politician talk at him in the senate for hours."

"So time is precious."

"Of course. Jikan are hours spent in service or in trade. The whole point is to be aware of the demands on your time, and to be humble when you ask others for theirs."

"It's not a very nimble currency, is it? Not like Shine."

"There are ways to trade jikan at a distance. If my mother lives in your town and you spend time to take care of her, you can trade those jikan to have someone else take care of your mother in their town. But you are correct; mostly jikan is traded where you live."

"All jikan is the same value. Why is that? Shouldn't a dishwasher and brain surgeon have different values for their time?"

"Who gets to decide this value? Simple Underneath is the template here."

"So there is only one type of jikan."

"There is only one value for jikan. An hour is an hour for everyone. Some jikan is mandatory as a part of grange membership or badge level. Some is reciprocal as a trade of services. Some is gifted to others as a contribution to social wellbeing. The last type is the basis for the global sharing economy." 
"And that's where jikan and Shine work together."

"Truly. People do appreciate it when you give of your time. They might offer you Shine, or they might pay it forward and help someone else. Either way, your gift is amplified."

“Takeshi-san, thanks for you time. I hope I haven't wasted this."

"It has been my honor, Simon-san. We are almost there. I must also warn you. They may be requesting the photograph of you."

"Nothing like a good lavatory scrubbing to build up your appetite. This is Simon, signing off from Osaka."

\section{TEN}

Julia Brookes, Ph.D. slipped her laptop into her shoulder bag. She peered into her coffee mug, contemplating a refill. That would make three already for the morning. What the hell, she decided. This conference is a rowdy bunch. They can take her with a full caffeine load. The coffee in the Hawthorne College tutor lounge was excellent. A local roaster delivered every Monday. A dozen or so of her colleagues were in conversation, or on the web, or doing emails at tables around the room, which had been formerly been the office of the department of history.

There were a lot of "formerly" spaces around the Santa Barbara campus. Most of it had been repurposed from what had been a tier one research university. Now it was a collection of top flight residential colleges, with a cadre of tutors that was the match of any campus on the planet. A couple of the larger lecture halls were used as theaters, the rest were now dining halls or public baths or multipurpose hacker or maker spaces. Gone were the faculty offices, so too the deans and provosts, the vice chancellors, and their secretaries and assistants. Gone as well was the position of professor, with its tenure and privileges. Julia was a tutor in the college. Tutor was the main academic job title. It sounded and paid better than her last job as an adjunct. 
That job was in a major public university in the midwest. She had just finished her first three-year contract when her position got "MOOCed". The campus decided it was cheaper to not pay her what amounted to six dollars an hour. Instead, they would subscribe to massive online courses produced elsewhere and made available for free. Free for the first couple years, they later discovered. Just until the administrators had soaked up as much of the reduced faculty payroll cost savings they could in their own salary increases.

She had found herself overworked and underpaid, and now, unemployed: this after she had sweated blood for six years to get her doctorate at Yale. Her thesis had been picked up for publication by Duke, and she had endured several interviews at the Association meetings, perched awkwardly on the edge of a bed in a business hotel, tugging at the hem of her dress, while three faculty quizzed her on her expectations for a job they had already planned to give to someone else. Somehow, all she could remember clearly from these interviews were their mustaches.

She swore she would not accept an adjunct position until the moment it was the only thing anyone offered. Then she poured all of her knowledge and energy into her syllabus. They assigned her four classes with fifty students each and zero support. No amount of coffee could help her grade two hundred ten-page papers in a weekend.

By the time she was not renewed, she had abandoned most of her daily personal routines: real food and exercise, anything that would have, perhaps, kept her from falling into abject depression. She returned to the house she had left a dozen years before on a shady street in a small town in Virginia, where she had been a top student and a member of the high school tennis team. While she had not been actually popular, she had been active on the school newspaper and website.

Her parents had made her old room into a computer den, with a futon couch/bed, which she reoccupied as though it would just be for a weekend or two, living out of her suitcase, open in the corner of the room. They were at turns supportive and condescending. Not too subtle hints about law or business school made breakfast uneasy for Julia. But their broadband provider was first rate.

Julia slept most of the first month. She slumped through the house when called for meals and took very long baths in the guest bathroom. She went online and joined the Junana social network, which her students had been telling her about for years. She found the Game, and her guide: Gabriele. And she and Gabriele spent many of her 
waking hours together for the next year pushing through the first four levels of the Game.

While on a free-for-all time excursion on a virtual pre-war Orient Express train that was steaming along somewhere outside of Strasbourg, Gabriele suddenly gave an audible gasp. His demitasse cup of espresso slipped from his hand, splattering on the wooden floor. He slid sideways in a faint.

"You are my masterpiece," he said, grandiose as normal. Then he shut his eyes and his avatar faded away. She already knew that Gabriele could not continue with her after Level Four, but the suddenness of his collapse and the finality of this moment hit her harder than she expected. Hard enough to make her angry.

Not just a flush of anger, like she would get when some idiot did something stupid on the interstate, or when an ass-clown radio host made another misogynist remark, she was angry at the world, angry enough to go outside and yell something, which she did.

It was the middle of the day and pouring down rain, so none of the neighbors caught the furious music of her obscene backyard rant. After she ran out of curses, and she had a good repertoire-she had almost memorized much of $19^{\text {th }}$ Century American literature-she stood in the rain, in her t-shirt and sweatpants, and she let it wash away her anger and her bilious chagrin.

She realized she was far more angry at her advisors from Yale, who failed to tell her that the academic job market for English PhDs was already in the crapper when she arrived. And angry at herself for throwing herself into a bullshit job that nobody respected. She screamed her rage at the rain clouds that cried softly on her upturned face.

"Gone," she whispered, hopefully, and a smile crept onto her face. She had just kicked ass on Level Four in under a year from the day she first opened the door to the Game. She marveled at how the templates could reveal new facets of knowledge in arenas she had previously mastered. Now that she could read ten times faster than before and with better recall, she was able to extend her academic interests well beyond what she'd accomplished for the dissertation. She was having more fun reading more books than at any prior time in her life.

"Only the beginning," she promised herself. And it was. 
Julia took a job in the single remaining bookstore in the town. It paid barely enough to contribute to her food bill and the monthly utilities. The owner had three years left on a twenty-year lease. After that, the store was sure to close. Julia worked nights on weekends and read more than she sold.

\section{$\S \S \S$}

It was noon already and they were still in Missouri. The freeway rolled through the Mississippi flood plain, which seemed endless to Isabella. Their new passenger, a middle-aged Sixer on walkabout, tried to engage her in conversation. Isabella faked a headache, closed her eyes, and hunched against the rear door on her side of the sedan. She clicked play.

"Simon here. I've got three minutes to talk with Adam Alba, from the Boar dachi of the Horse gumi of Grange 95,481 in Austin, Texas. Adam has a Master Level One badge in 'Slack.'”

“Tell me about slack, Adam.”

"What's to tell?"

"Can you explain the true essence of slack?"

"It's no secret. The essence of slack is 'chill'. Chill when you wake up. Chill all day. Chill before you get to sleep."

"With all that chilling, how did anyone manage to organize a craft hall in Castalia for slack?"

“True slack takes dedication and a great team. You can't really go slack on your own. Otherwise things get parallaxed in a hurry."

“Parallaxed?"

“Completely. Anyhow what's a grange without the promise of slack?”

"Expand on that, will you." 
"The grange is set up to take care of the daily needs of its members with the minimum of a time commitment, so they can pursue their personal goals. My personal goal is to chill."

"Chill is the word."

“O.K., great talking to you.”

“Wait. Don't go away. There's got to be more to it than just 'chill'."

"Slack is a science, you know. Or an art form. I can't really decide."

“But you still need some jikan?”

"Sure, the trick there is to get badges in stuff nobody likes to do."

“Give me an example.”

"I'm a journeyman elder-care specialist, a dog walker, and bamboo crafter. Always find open daily roles for that shit."

“Elder care?”

"Nothing more slack than a geezer on his meds."

“OK. How do I get my entry level badge in Slack?”

"There's a test on Junana."

“O.K., So I pass the test.”

"Not if you want your badge. You gotta fail that mutherfuckin' test, and fail it righteously. You have to embrace the failure that's going to define your life, man."

"If you chill all day, every day, how do you stay in the grange?"

'I call it the 'slack attack.' If you want to defeat Tension at the Edges and stay slack in the grange, you gotta work together. You need two dachis fully committed to slack, you see, and then they take turns being more slack than the other one. That way neither can be kicked out."

"So it's a coordinated competition. That seems really clever." 
“Only got two problems. First one is that most slackers aren't what you might call coordinated or competitive. Second one is that all too often a slacker stops chilling and finds something, you know...useful to do. Before long they are lost to slack."

"Because of a lack of dedication..."

“Damn straight. Let me tell you what's been the kryptonite for many a fine slacker." “O.K...Adam is very upset here. What is slacker kryptonite?”

“Frolicks! Fuckin' frolicks seem simple enough at first. 'Let's go downtown and parody the lifestyles of the hipsters'... nothin' wrong with that, you say. An hour of good clean fun. But before you know, there's costumes to be made, and signals, and pantomime moves or lines to be learned. Pretty soon there's music and even choreography. Why, it takes more jikan to pull off a really great frolick than it does to build a new house. The poor slacker who just wanted some lulz on a sunny Saturday starts piling up the jikan and taking classes on make-up and puppetry, and they're giving him Shine and badges. Shit, once you go full frolick, you can't come back from that."

“So, no frolicks for you."

“No, sir!”

"I'll let you go now. What's your plan for the rest of the day?"

"I've got my burrito."

"For my listeners. Adam is holding up a burrito big as a Texan haggis, swaddled in tinfoil. Adam was going to tell me about his day?"

“...I was?” There was silence.

“That's all right. Thanks Adam. Have a good one. This is Simon, signing off from Austin."

$\S \S \S$

Julia Brookes was already a Sixer when she joined the local grange and moved out of her childhood house for good. While she had just missed being the last Yale PhD to be hired as a tenure track English literature professor at a major university, her timing 
was perfect to be one of the first of the cohort of academics that overturned the academy and reinvented intellectual work.

Being a Sixer, she had several options to pursue. She considered becoming a SpimeCop. The WholeTale market was just opening up, and there was a general call out for more regulators. WealthMinder was another option, but she had always been somewhat uncertain about her own bank balance, so she suspected this was not in her future.

The news about the massive student walkout at Stanford confirmed in Julia that the time was ripe to re-imagine being an academic. She had been following the blog of Robby Robinson, who had predicted the collapse of the higher educational establishment years before. He had a vision of what might replace this, however the vision needed pioneers who could push Game-centered learning to its flower.

Julia requested a meeting room for academics in Castalia, and posted its location and the time for weekly meetings on the Castalia digital notice boards. The agenda was simple: organize craft guilds and badges for the humanities and social sciences. To her surprise, Robby showed up at the first meeting. So did several dozen other Gamer academics.

It would be two years before the curriculum for master level badges became available for most of the subjects taught at major universities. Many of the academic disputes from the past century had to be refought in the process. The arguments were mainly about intellectual territory. Theoretical fences as stout as Rabelais's reimagined city walls. All would need to be revisited, undone, and then rewoven into an active intellectual commons.

Robby explained that these arguments were cleansing. In a few years, a smaller set of the most interesting and useful badges would win out. Robby was very strict about the process of approving the master badge levels, and the practices that students would follow to achieve these skills. He grounded his opinions fully in the templates.

Some examples of Robby's thinking were striking to Julia. The first was to absolutely separate teaching and evaluation. Teachers would no longer grade their own students. Instead, teachers and students would evaluate students and teachers from other conferences through a single badge-wide system. Once evaluation was fully externalized, once kissing-ass had no impact on the final score, academic conference discussions were freed to become much more honest, productive, and provocative. 
The second example was to insert a lottery into the selection of academic jobs. Robby had been working with Winston Fairchild on the benefits of a random selection layer for all executive positions. The object was to remove the levers of corruption. Anybody who wanted an open, advertised position would first need to earn the prerequisite badges and Shine in order to enter the job's lottery. The three to five finalists who won the lottery would compete for the job. This eliminated inside track appointments and pro forma job searches.

“When students aren't afraid to speak up to their teachers and when seduction or coercion aren't enough to guarantee a job placement, then the world is a more reliably interesting place," Robby told her.

The final piece of the emergent logic came from a template: Tension at the Edges. Organizations need to be reflexive and responsive to new situations. For this, Robby figured that the top performers and the bottom performers should be rewarded or punished. Anybody who under-performs for more than a year needs to find new work or a new place in some other field or social setting. Those who constantly over-perform need to be celebrated and supported to share their methods. Tension at the Edges pushed the deadwood downstream and gave the blossoming flower more sunlight.

By then, Julia had become a Meister in the Game, and had met two of the Grand Meisters in Castalia. When Julia met Grand Meister Desi, he told her the story of how Robby had unfolded the Intentionfull template strand, upon which the entire Game was built. In all of their conversations, Robby had not even hinted at this. Grand Meister Jennifer, newly elected to the Collège de France, took time to congratulate Julia on her work.

“The academy needs more like you," Jennifer said. "I think there's a place for a new fork in SilvasAcademi for your badge research. If you like, we could work together on something." That pretty much made up for every insult Julia had suffered in graduate school seminars.

Julia had nothing to do with the opening of SilvasAcademi, the global git repository for academic output, except to jump at the chance to get her ideas into the mix. Parts of her dissertation on Mark Twain and 19th Century realism in American frontier fiction entered an early version of the American English literary criticism corpus. Since then, much of what she contributed has been edited and enlarged upon. 
With all the academics in the world contributing to a single rhizomatic research hub, the tattered edges of old disciplines gave way to new nodes of interwoven knowledge. The natural science end of this hub bristled with connections to data archives, workflow engines, and models. The humanities side anchored into cultural artifacts and literature. Contemporary sciences, the new label for social, cultural and information sciences, cut their own wedges into the corpus and linked out to social bigdata repositories. They soon limited new additions to SilvasAcademi by Badge level, opting for quality over quantity. Even as a Level Three Master, Julia could only add or edit a few hundred words a year. She spent as much time on these words as she would on an entire monograph.

\section{$\S \S \S$}

When Julia won the lottery to be a finalist for a job as tutor at Hawthorne College in Santa Barbara, California, a big part of her figured that was as far as she would get. The job offered enough bonus jikan to take six months of research leave after four years. Then she would be back into the lottery, like everyone else. Her teleconference interview went well. One of them mentioned how much he liked the sample syllabus she had sent. She was contemplating the irony of that as she hung up. The job offer happened the next day.

Julia filled her coffee mug to the brim. Her phone jangled. It was a text from Robby Robinson. She had invited him to Santa Barbara to give a talk on the future of higher education. He confirmed he would be arriving on Thursday evening. She would finally meet him in person. Toting her laptop, she strode down the hallway to the conference room where she would see just how well her students had estimated the work and literary life of the $19^{\text {th }}$ Century American author, Bret Harte.

\section{$\S \S \S$}

Up front they were playing some new dark ambient tune, which matched Isabella's mood as the car sang down the interstate surrounded by tractor trailers as it sped through Arkansas. 
"This is Simon here. I'm on a grange in the countryside a couple hundred miles north of New Delhi, near the city of Dheradun. I'm speaking with Lakshmi Sharma, Level Two Journeyman Cultivator. My Hindi is nonexistent, so we will rely on Doc Do. Lakshmi, in three minutes what can you tell me about grange number...?"

"You should be talking with the Grange Manager. Or one of our Meisters."

"I'd rather talk with you. Do you have three minutes to spare?"

"Certainly Grand Meister. This is grange ninety-seven thousand six-hundred and twenty. We call it 'six-two-oh.' I can say this is a true grange. We share our tools, our skills, our seeds, our hopes, our troubles, and our bounty. Come with me."

“I believe I've been neglecting rural granges in my travels. We are walking through a busy yard surrounded by barns and all manner of farm equipment. Maybe a hundred people are busy loading what looks like sacks of seed or tending machinery. And over there, in an open space across from the barn must be fifty people all dancing. What is that?"

"They're shooting a film. They use our planting activity as a backdrop. Probably a love scene. The couple will be playing hide and seek around the grain sacks. Do you want to join?"

“Looks like they’ve had lot of practice. I'd better not."

"I'm certain they can teach you."

"I'd ruin all their takes."

"As you wish. Where was I? Rural granges are the real granges. After all, a grange is just another word for 'farm.' The true test of a grange is its ability to offer credit and cushion the bad years. All farms have bad years, what with weather, pests, and the changing market. Every farmer needs to borrow in bad times. Before the grange happened, local money lenders charged a cruel rate of interest."

"How do granges help?"

“We've all granted the grange a conservation easement for our farmlands. Essentially, we all own the lands together in common. We are all commoners here. The former landholders get extra shares from the profits, but make no claim when there are losses. Our sharing union is a member of a regional association that arranges credit at 
very small, and even at no interest. There is a lot of Gandhi-jis philosophy in our grange, and, of course, hundreds of templates."

"Is agriculture itself changing?"

"Even more than before we are looking out for the long term. We have sent our best students off to get their badges in sustainable agriculture and permaculture. Some are in the States even."

"Any other changes?”

"There is one..."

“One...?”

Simon continued. "...Lakshmi is pretending like she's not going to tell me... but you are, aren't you? I don't bite."

"Simon. This is personal! Well, all right, since you are the Grand Meister. The Game has been really excellent in determining marriages. So many happy couples! My Guide found Rajiv for me, from a grange way over in Chandigarh. When planting is done here, I'll be going back to his grange. Probably for a long while."

“I’m so stupid, I didn't even notice. Congratulations! How far along are you?”

“Ten weeks.”

"Is this your first?"

“Yes, we have been waiting until I'm thirty. My parents don't understand at all. They've been hounding us for years. My mother was fifteen when I was born."

"You're stretching the generations."

"We can reduce the fertility index without giving up on having children. All of the granges here are offering jikan and AirShip tickets to couples who wait."

“Where will you go?”

"I have always wanted to visit Australia. We have tickets on an AirShip to Melbourne next month."

"Tell me about your parents." 
"My appa once had ten acres of mostly garden plots, near to water. After a bad year, he lost the land to the lenders. We stopped him from drinking insecticide."

“He was suicidal?"

"Losing your land is like losing your soul. My amma's family were hired labor. She was a beauty. She still is. Today they are both associates at my Rajiv's grange. My amma is struggling so with Level Two."

"It's a very hard level. I had to go through it twice."

"You?"

"I was not very mindful of the Five Skillings when I was younger."

“Like my amma. Can you talk to her?"

“We will connect on Junana. You can introduce me. I’m sure she’s trying.”

"She’s trying all right. Trying my patience. She needs to work on her internal voice."

“That's a life-long effort."

“...and sometimes her external voice."

"Can't help you there. What's this building?"

“These are our baths?”

"Let me guess."

“The men's toilet is to the right. I must warn you, we've welcomed a hundred extra workers for the planting. It won't be pretty. It's a composting system, so there's quite a bit of gas when it gets this busy."

"It will be extra pretty when I'm done. This is Simon in North India saying so long..."

"Take this..."

"I need a brush, not a mallet."

"The brush you will find inside. This is for the roaches. We must have the biggest tilchatta anywhere. They can fly and they bite like rats."

“Really. Well. Hmmm. Is it too late to join the video shoot?" 
"Not at all! Let me introduce you to the director."

"This is Simon signing off from grange six-two-oh."

\section{ELEVEN}

Nick Landreau opened the door to the conference room. Formerly a professor's office, it retained a wall of bookcases, mostly empty, and a whiteboard. Instead of a desk, an oblong wooden table took up most of the room, surrounded by a dozen padded armchairs. The window faced west, out to a sunny, tree-lined courtyard. Most of the conferees were already seated and focused intently on their last-minute notes. A couple were still doing their brainwave hand movements. Coffees and waters were arranged next to laptops. Nick took an empty chair. The room's silence was frosted with anticipation. The next ninety minutes would pass as quickly as a championship soccer match, only the goals would be intellectual, and the passes verbal.

On tap for the conference was the work and life of Bret Harte, who wrote in and of California in the 1860s. Of course, any American writer prior to that could be entered into the conversation, and so the reading list for the day was unrestricted.

Nick opened his notes and refreshed what he had studied the night before, including all of Harte's early stories, and those of other, prior humorists, mostly from the South, as California was new literary territory at that time. Nick had another two weeks of biweekly conferences before he could sit for the exam for a Journeyman Badge Level Three in $19^{\text {th }}$ Century American literature. A badge that would qualify him as a regular high-school English teacher.

Hawthorne was one of the twelve residential colleges that were carved out of what was the University of California, Santa Barbara. The college had newly occupied a six-story building, formerly the home of several academic departments. The ground floor had been gutted and redone as a dining commons, a coffee lounge, and a small pub with a music stage called the Tanglewood. The second floor was devoted to conference 
rooms. Additional bathrooms, showers, and lounges were added to each of the residential floors above this. About half the college roomed in one of the old dorms near the beach.

Hawthorne College was a non-profit corporation, its mission was to teach a wide range of content leading to master badges. Like any Game grange, the college was divided into dachis and gumis for social reasons. These groups organized events, frolicks, and intramural sports teams for the full-time student members. They took turns cleaning the common spaces and lavatories and working in the dining room. Its members did not buy shares, as they would only be temporarily in residence: most badges took a year or less, although some students would earn several badges over the course of some years.

Hawthorne used peer teaching as the rule. Students learned by critiquing each other's work. Actual grading was external and anonymous. On any week, Nick might be evaluating a peer at a college in Sri Lanka. And his work might be reviewed by a student in Romania. Badge holders earned Shine reviewing the reviews-creating still more learning moments for students. Teachers could access, but not alter, the external reviews of their students. They were not allowed to award or deny badges to their own students.

Everyone had the opportunity to rate the conference when the term ended. In most conferences, the students would give a Shine stone to the peer they thought contributed the most. The tutor paid extra attention to the overall badge test score for each student, based on an extensive pre-test and the results of the badge examination. The greater the difference, the higher the teacher's score. Higher scores meant more Shine and a chance to enter the lottery for campus prizes, including extra sabbatical time.

Nick looked around him. All of the class were at least Fourveys in the Game. Two were Sixers. Half were not yet eighteen years of age. Their tutor was a Game Meister and a Level Three Master badge holder in American literature. Nick hoped she had taken it easy on the caffeine today. Meister Julia Brookes was not famous for being a hardass. But she also knew enough to not suffer any bullshit.

Nick checked his notes. His "I do not understand" question was ready. After a quick survey of the corpus, Brookes would go around the table and each person had to ask a question about their reading, starting with the phrase "I do not understand...". The class would then discuss this. Her reasoning was pure. If you understand everything 
you read, you're not reading the right stuff. If you think you understand what you read, you're not thinking hard enough. Knowledge begins with Humility was the first template in her conference. She always ended this part of the class by saying what she did not understand, to engage the class to teach her something new.

The door swung open. Julia Brookes entered and they all looked up and greeted her. Her eyes swept across the room.

"Where's Griff?" she asked.

“Infirmary,” someone said. "Tore his ACL yesterday playing ultimate frisbee.”

"That's a better excuse than last time." She sat down and opened her laptop on the tabletop. "One announcement before we start." She smiled at them.

"I have great news. Rob Robinson will be speaking this Friday evening at Campbell Hall. Seven PM." She removed her glasses and settled back.

"Who wants to summarize the SilvasAcademi entry on Bret Harte?" Around the table, hands appeared.

\section{$\S \S \S$}

They stopped at a Rooster gumi cafe off of Interstate 55 outside of Memphis for a late lunch. It was a chicken and waffle joint called Cookadoodledo. A cuisine new to Isabella. She got the Sixer to start talking about herself, and maneuvered around questions about her own past. Since she was headed for Biloxi to bury a grandfather, they probably figured she was just depressed and sad. Back on the road, Isabella popped in her earbuds.

Hello, Simon here. I'm walking along the Quai d'Orsay with fellow Grand Meister Professor Jennifer Bouchez."

"I'm Jenn and you're Simon. Let's get that straight."

"Sure. We are between rain showers. The sky is dark, the river looks like flowing mercury. The gutters are flush with... woah, what is that?"

“Don't ask." 
"I think I just saw the chupacabra."

“Don't be silly, it's just a canal rat."

"Jenn and I are headed for a cafe before the next squall."

"If we're lucky. We'll need to get over to Rue Saint-Dominique. Just promise me you're not going to offer to clean the WC when we get there," Jenn said.

"I’m thinking a pain au chocolate and an espresso."

"In that case, we can talk."

"You gave a lecture recently on how badges have emerged from the academy into the general economy. You have three minutes to tell the world what you meant."

"It was a sixty minute lecture."

"So, give me the best part."

"Without badges, the Junana sharing economy would have never taken off. And without the granges, the badge system would not have grown so fast and made such an economic impact. There. Fini."

“Badges and granges fit together so well, it's hard to imagine one without the other."

"The granges are dynamic work-spaces. They replaced the idea of employment and unemployment with the earlier notion of craft and service and also with the more recent idea of occupying roles instead of jobs."

"What is a 'role,' exactly?"

"A role is a bit of work as described by its purpose, field, and activities; something that needs to be done within its own time. Contrast this with a job. A 'job' is a position that may have many under-defined roles. It may also acquire or lose roles without the job holder's agreement or even awareness. But when you accept a role, or several roles you always know exactly what is expected, and you fulfill this as you can and want. You are the CEO of that role."

"Let's say I want to build a... house..."

“Assuming construction is underway, today's roles might include rough carpentry, wiring, plumbing, materials delivery, providing meals to the crew. Each role is fully 
autonomous. Coordination happens at the beginning of each shift."

"I've got a badge for a role. How do I know if there is any work for me today?"

"Every grange has a list of roles it requires for the day. This list changes constantly. When I arrive at the grange looking for new work I simply log in and I am presented with the unfilled roles that fit my badges today. I select the ones I wish to do, and get to work."

"So if I have a badge as a carpenter, I just log in and accept an open shift. What if there are no open shifts?"

"Each member looks to increase the number of roles they can fulfill by earning more badges. If nothing is available today, perhaps it is a good day to take a class in a new badge. Earning a Master level badge opens the role of mentoring others. Some roles are weekly, monthly, or even yearly."

"But what if I'm a really shitty carpenter?"

"That's where Shine comes in. Every time you finish a role, your team members can comment and add appreciation. Better Shine leads to being chosen more often for longer roles. A lack of Shine begins to drag on your ability to get these longer roles."

"How do I fix that?"

"Badges build Shine too. You might need to go back to school and reacquire your badge. That resets your ratings, but your instructors will be much harder on you the second time."

"If I'm a great carpenter..."

"If your rankings are really good, then your badge and your Shine are all you need to step into roles anywhere. Your accumulated jikan can be traded for goods you want to buy. The grange will provide you tools and shelter. You never really need money, although factory jobs also pay basic wage."

"How did the badge system get started?"

"A group from the Nozilla Foundation designed badges for the spectrum of educational achievement. These ignored disciplines and diplomas in favor of information gathering and problem solving skills. The first non-academic badge awarded was a Fabricator Journeyman badge at grange 659 in Chapel Hill, North Carolina. 
"So badges didn't start in Castalia?"

"Not at all. The granges are their own innovation engines."

She continued, "Let me ask you one. What badges do you want to earn in life? Or are you just going to get on by being Grand Meister?"

“You mean, 'What am I going to do when I grow up'?”

"Assuming you want to grow up."

“Frankly, I have no idea at the moment. That's why I'm on this extended walkabout.”

“Perhaps you can be a Level Three Master nomad? That wouldn't be a bad career.”

“Look."

“Merde."

"Over across the river, the whole Grand Palais just disappeared into a furious rain squall, which is blowing our way. We had better find shelter. This is Simon signing off from Paris."

$\S \S \S$

"He broke the fucking mesh," Tuong Nguyen looked around the table. A score of faces stared back at him under the glare of the fluorescent overhead lights. "We're driving this train across a trestle and he dynamites it."

Tiny walked back and forth between the table and the wall with the whiteboard. As big as he was, he moved with little seeming effort. It was midnight at the computer center of Sao Do, which meant the center of the code universe if you were a Gamer. The entire tiger team Scratchy had hand picked to run the Castalia software sat and watched their leader expectantly.

"It's his mesh, we can't touch it." A voice rose from the table, others muttered in agreement.

"If he breaks it again... I mean when he breaks it again, I need something that will shake him up good. We're here all night gentlemen... and Thuc." He nodded at her. 
“Ideas anybody?"

$\S \S \S$

Chelsea Wilde settled onto her futon on the floor of the main room of grange 385002, which occupied the site of a former Piggly Wiggly in Bonifay, Florida. She had arrived from a grange in Panama City where she sloughed off her identity as Isabella Seargant. She was given her new IDs and also had her hair cut above her shoulders and died a bright red. She would have picked blue, but they insisted.

"You could also put some gel in that, honey," the hairdresser said.

Tomorrow she would travel through Atlanta on her way to Asheville, North Carolina. Too excited to drop off to sleep, she popped in her earbuds.

"Simon here. I'm still in Sao Do, and I've got three minutes with Michael Scratchy O’Hara, the man who discovered 'Choose One.'”

"I've got a telecon with the Nerds in five minutes," Scratchy said. "Let me ask you a question first. Why podcast?"

"I love listening to people talk. Podcasts are like radio. I've always enjoyed radio. My father had a radio show for years. I used to go to the station with him when I was really little. Don't you like podcasts?"

"Podcasts are great. Just the right bandwidth, and you can listen to them while you watch porn. My question is, why not meander around the planet, have some yucks, shoot the breeze, dally in Delhi or whatever, and then go home? Why should anybody listen to these?"

"I hope they're not listening to me. I'm just here to ask questions. All across the planet people are not just learning the templates, they're living the templates. These are their stories."

"You want templates, you should talk with Desi, not me."

“We talk all the time in Castalia. I want to know what's new with you." 
"New? Jack and Winston have been particularly busy the past year with a group of meisters who are also active Game B economists."

“Game B?”

"That's Jack-speak for how the Game will impact the global marketplace. His original idea was to find an emergent complex innovation, but we punted on that and went with the Game. We figured a few hundred-million teenagers might come up with their own Game B.

"So what keeps you busy today?"

“They want Itchy and me to build something 'like nothing the world has seen before,' which happens around here a lot."

“They call Sao Do 'silicon village,' so much of the web is now running on Sao Do code.” "The code is running on the original design templates, which anyone can use."

“Because you licensed them for reuse instead of selling them for billions."

"All good deeds will be punished. I'm a poster child for that sentiment. I have a feeling your punishment will come at some point. The powers that be don't like getting jerked around. Your annual Frolix will piss them off someday."

“What keeps you up at night, Michael?”

"I'll tell you. None of this code is really durable. Its lifecycle is way too short. Everything we've done here will come unraveled before long. We need to find a way to make this code superversatile."

\section{"Superversatile?"}

"The opposite of fragile. It means when you fuck with it, it just laughs and gets stronger."

"'Choose One' is still the most basic root template we know about. How did you discover it?"

"Let me see. I'm sure there was beer, and I might have been in the tub, which means there were farts. Other than that, I guess it just came to me. Templates aren't like jokes. You don't invent them. All the templates in the world are already in the world. You don't create them, you just uncover them." 
"Still, it was... revolutionary!”

"Hell no. Revolution is for technology, like evolution is for biology. Templates remind us of what we've already learned. They just help us dance faster than entropy."

"You know, you are still 'The Judge' for the Magisters of Castalia."

"Isn't there a statute of limitations on that?"

“Just because we haven't made use of your wisdom yet, doesn't mean we've forgotten."

"Better hurry up then, my wisdom is getting old, like me. Hold on..."

"Is that your call?"

"'Fraid so."

“This is Simon signing off from Sao Do. I'll try to get another three minutes with Scratchy tomorrow. I've got a lot more questions."

Scratchy said. "Itchy, I've got Simon Bishop here. He says he's got a lot of questions. Isn't that why we invented the fucking Game?"

\section{$\S \S \S$}

"I call it 'Atmosfear'." Thuc Huynh wrote this on the whiteboard. "It's a robust seeded cloud computing profile on the open-cloud framework, with the entire Castalia code and data built in." This was Thuc's first week on the job. Scratchy had recruited her right out of the Hanoi Institute of Technology, where she won the prize for her noSQL database design.

"A cloud?" Someone spoke up. The voice was harsh.

"How does it scale?" Tiny asked, glaring at the owner of the voice.

"That's really the issue, right?" Thuc looked across the room. The others were not going to back her up on this. They had grown up on the mesh, and considered cloud computing something from the start of the century. "With the mesh, there is no real theoretical limit, as each member adds to its capacity. Atmosfear runs great up to about ten million simultaneous users." She scrawled this number on the board. "It runs OK with twice that number, and then it really dogs." 
"So we can't use it..." Tiny cocked his head a bit, like he was trying to figure out why she would waste their time.

"Unless we can mirror the data stream..." Thuc set the marker down. "Once we do, we can certainly configure a content delivery network to optimize performance."

“We're talking five petabytes here," a voice spoke.

"Not really," Thuc said. "All we need to mirror in real time are the data about the current state of the system. A couple terabytes, max."

"We have a terabit optical fibre conduit between four of the continents, if we mirrored at our hubs in Asia, Europe, Africa and North America, we could serve up to forty million users, that's twice the headroom we need," Thuc nodded at Tiny and sat down.

"Have you tried to build the mirroring code?" Tiny asked.

"I figured you guys would want something to do." Thuc sat back and folded her arms.

\section{$\S \S \S$}

The lights in the crowded former lecture hall dimmed as a spotlight picked out the lectern on stage. The din of the expectant audience gave way to applause.

"Looks like we're on," Julia Brookes said. She was standing in the wing of the stage with Robby Robinson and two of his local friends, Megan Doolan and Nick Landreu, who was in one of her conferences. She walked out on stage and stood behind the lectern.

"A decade ago on the Junana social network, a door appeared announcing a new Game," she started. "We all know what happened then..."

A cheer went up in the room, with more applause. She waited.

"No aspect of our society was impacted more than higher education. And no one person on the planet is better equipped to talk about these impacts than our speaker tonight. I am very honored to present the man who first unfolded the template Intentionfull..."

More applause, this time with whisperings. "He's also responsible for bringing Jorge and Wanda into the Game..." she said. 
This brought the raucous crowd to their feet. People, mostly women, started chanting "Jorge, Jorge..." This brought a return chorus of "Wanda, Wanda" from others.

In the wings, Megan gave Robby a hug, which he shied from, so Nick got him with a bigger hug from the other side. "Go get 'em!" he said.

"Give it up for Robby Robinson!" Julia gestured over to the side of the stage where Robby emerged into the spot light. He was dressed in chinos and a pull-over sweater.

“Thank you, thank you. Julia Brookes," Robby said and nodded to her. Julia waved at the crowd and then retreated.

Robby let the crowd settle down. The room was packed. More than eight hundred in here, and several hundred more in an overflow hall. He pulled the projector remote from his pocket and queued his first slide, an urban street with a crowd of teens all wearing brown shoes and Yanagi University hoodies.

"I'll keep this short. I know you all have concerts and better things to do tonight. Tomorrow morning I'll be doing an AMA on the Hawthorne College wiki, and this evening I've been told I will be led through all the college lounges and bars, so please save your questions." He took a deep breath.

"Over the past ten years, more than a billion people have earned their Game shoes. Four hundred million Yanagi University diplomas have been sent out, along with hats. Forty million shoulder bags, more than a million Sixer blouses, two thousand cloaks, and three Grand Meister staffs. This represents more than two trillion hours of Game time. That might seem like a lot, but most of this replaced all the time that would have been spent watching television."

Robby looked over the crowd. Most of them might spend four hours a day or more on the game, but they would be horrified to even consider watching the same amount of television, even though their parents did just that. Gamers are immersed in a new economy so slyly distinct from its surroundings that older practices seemed peculiar.

"No other sector of the society was transformed more than was higher education in this new economy. The Game rained learning across the planet. Great lakes of knowledge flooded a broad range of human action, dwarfing the ponds once provided by universities.

"At the start, the more nimble private colleges joined with cash-strapped state schools, which hopped onto the Game as a free learning engine. Gamers entered campus as 
freshmen with more intellectual tools than did most doctoral students before the Game. In the first year of the Game, professors were simply delighted that their students were so very capable. In the second year, professors were shocked that their lecture halls were mostly empty.

"Gamers would sign up for a class, read the syllabus, gather in Junana, and complete the semester's work in a couple weeks. Colleges began to require lecture attendance. Gamers responded by creating their own classes in dormitories and coffeehouses, withholding their tuition, and forming entire shadow universities. Some faculty and most graduate students also took to the Game, if only to keep up with their younger peers."

The next slide was of a small conference in a cozy room. A dozen Gamers sat in rapt attention as one of them spoke and gestured.

"Gamer faculty flipped their lectures into group discussions and students returned to the classrooms. Non-Gamer faculty, who tended to be the more senior and controlled many departments, mostly responded by proposing penalties for using the Game in the classroom, escalating the divide between those departments that allowed the Game and those that prohibited this.

"You can read about what happened next at Stanford and elsewhere on Wikipedia. The colleges here in Santa Barbara are the direct result. We are, all of us, grateful that intellectual production has been sustained as a feature within the growing global grange economy. Granges and their mura donate millions of hours of jikan and a great deal of Shine so that their members can acquire master badges. No society in the history of humanity has had more of its people exposed to advanced knowledge. And nobody today is forced into a lifetime of debt to pay for their passion for learning."

The next slide was of a grange somewhere in Asia, bustling with midday activity.

"How many here are tutors?” A hundred hands extended.

"The livelihood of the academic, which was once chained to the promise of tenure in a single department or to a lifetime of low-paid adjunct positions, is now anchored by basic wages and augmented with the Shine each person can generate through their work. The marketplace for tutors across the nation and the academy's badge space is well known, as are the odds of the lotteries for open positions. Everyone with skills has the same opportunity, and those who are not selected this year can find work in their granges and time to study for another year. Thousands of Master badge holders teach 
online through their Badge guilds. I'm happy to announce that intellectual pursuit has never been more ubiquitous and more satisfying..."

"Says you!" A voice boomed across the hall.

\section{TWELVE}

"I'm sorry." Robby shielded his eyes from the spotlight. "Do you want to contribute to the conversation?"

The attention of the crowd shifted to a man, portly and balding, dressed in a dark suit and a blue tie, standing in the center of the auditorium.

“Can we get our friend a microphone?” Robby pointed at him. A technician was already running down the aisle. She passed a wireless microphone to the person on the end. This went from hand to hand.

The man snatched at the microphone. "Do you realize what you've destroyed..."

"Please introduce yourself, so I know with whom I'm speaking."

"Geoff Koenig. I was vice chancellor here for ten years, and professor of linguistics for thirty. Now I'm retired, not by choice, mind you."

"Professor Koenig. I have had the great pleasure of reading your work on topicalization in Portuguese."

“Don't try to brown nose me, Robinson. You and your Game took three hundred years of science and learning and flushed it down the toilet. Millions lost their jobs. Can you imagine what it feels like to have everything you counted on yanked out from under your feet?"

"I can tell you I've met dozens of former vice chancellors who share your perspective. I have to be honest here; I'm glad their words are sharper than their fists. Do you know 
how many people are now working as teachers in higher education?"

"I know that none of them have tenure."

"More than ninety percent of the number ten years ago."

"So says you. Everyone I know in the academy is now fucked. They're working in discount shops and clothing stores and selling insurance or appliances. They're running laundromats, for Chrissake."

"I see. I did not mean to suggest that the very same people were still teaching, only that our national investment in teaching and learning has not declined. Quite the opposite. Ten times that number are mentoring in their granges, sharing their knowledge and Shine."

"Do you know how many vice chancellor positions remain in the entire US?" "I think I will, very soon..."

"Seventeen."

"Seventeen. Professor Koenig, I can only say that hearing this is one of the proudest moments of my career. Please sit down."

"Eat shit, Robinson! This... all this... is your fault!" The man dropped the microphone which hit the concrete floor with a sonic snap. He began to wade toward the side aisle, mouthing curses as he went.

At the top of the aisle Koenig turned and flipped him the gesture Robby was expecting. He had received plenty of these from other former department chairs, deans, provosts, assistant-, executive-, and vice-chancellors. Robby gave him a wave in reply as Koenig exited through the back door.

“Let's be fair to Professor Koenig. These past several years have been disruptive and economically difficult for whole cohorts of former university administrators and tenured faculty. Let me ask how many here once held a tenured faculty job? Please stand up."

A couple dozen individuals stood up. "Thank you. I'm going to ask you to do something for me. Please stay standing. If you are still teaching in some capacity, raise your hand." Nearly all of them did so. Robby went to the front of the stage and gestured at 
them. "Look," he shouted to the crowd. "This is why I'm so proud to be an American intellectual today."

\section{$\S \S \S$}

Chelsea Wilde arrived in Asheville late in the day in the back of a Noël sedan almost identical to the one in which Samantha Mooney left Santa Barbara. She had been keeping a low profile for some days at a rural grange on the Florida panhandle until the arrangements for her grange were finalized. Her last ride from Atlanta, with stops in several granges on the way to drop off passengers, took almost six hours. Chelsea had been accepted into Grange 405891, Asheville's newest. Chelsea had been admitted into the Rat dachi of the Rabbit gumi. Her new biography had her growing up home-schooled in Reseda, close enough to Santa Barbara so that she could talk about shopping in LA, trips to the beaches, and skiing up at Mammoth.

While the Grange had plans to become a full-scale crafter and fabrication outfit, it also had a contract as the service college for the nearby campus of the University of North Carolina. The campus had recently been reconfigured into four grange colleges: Carlyle College, Dickinson College, the smaller athletics-focused Jordan College, and the faculty's Biltmore College. With only 4,000 students, it was too small to have a dedicated service college.

Chelsea would work full time to pay for her grange membership fee, her monthly dues, her room and board in the gumi house, and her campus dining card. Once her membership fee was paid, she would be on half-time, and eligible to take badge classes at the colleges. She had been offered a room in a Rabbit gumi shared house, a woodframed, fifty-year-old, four-bedroom structure north of campus, on nearly half an acre, most of which was devoted to vegetables, and with a giant bamboo hedge. The mura had purchased and was remodeling a defunct strip mall on Marrimon Avenue, not far from the house.

Her roommate was out when Chelsea arrived. A housemate, an older man named Shawn, who she later discovered was a master plumber, helped her with her luggage and explained some house rules about no shoes upstairs and no showers over five minutes. He rolled her luggage over to an empty chest of drawers, showed her where her futon was stored folded in the room's one tiny closet, gave her the wifi password, welcomed her again and left, closing the door behind him. 
With two small desks with chairs and two chests of drawers, the room seemed fairly big. At night there would be two futons on the wood floor. Her roommate's side of the room had a number of books on its wall-mounted shelves, and a desk top littered with electronic computer parts. Chelsea opened the closet, just deep enough for the folded futons to fit on the floor. She counted five empty wire hangers. A large, double-hung window looked south, downhill toward the campus. It was wide open and screened. As the night deepened, a cool breeze picked up. She opened the door to encourage it. Chelsea grabbed her laptop, flopped down on a caned chair in front of her desk, and booted up the Game. Moses greeted her as always.

“Hello Chelsea. I trust you are finding Asheville to your liking.”

"I’ve hardly seen anything yet. And I start work at seven tomorrow."

"Give it some time."

“Time? Have you seen my schedule? I'm on kitchen duty all day. At least I can keep listening to Simon Sayz while I work. Where is Simon Bishop? Do you know?"

"Like you, Simon is deep into not being found. Asheville will be your new home, and a genuine opportunity," Moses said, in that lilting afro-British accent that made the word "opportunity" into a rivulet of syllables. "It will be a real challenge for you. Cleaning and serving. But you can enjoy the novelty of tedium for a brief time."

“Two years, Moses. I'll be here for two whole years.”

"To be sure, but the novelty will wear out in a week. Then you have only the tedium." His smile, while unchanged, seemed different.

"So, this is a punishment."

"Why would the world wish to punish Chelsea Wilde? She has done nothing." “How about Samantha Mooney?”

"That rich girl from Santa Barbara? The one who was given everything she ever wanted and traveled the world as only a princess might? What punishment does she deserve?"

"I never chose to be a princess," Chelsea said, not liking the direction of this conversation. 
"Princesses never do. Funny that is. Neither do servant girls."

“Don't I deserve what anyone else deserves?”

"And what is that, precisely?"

“I don't know. Respect. Maybe even love." Chelsea was tearing now. “Doesn't everyone?"

"Respect is something you find inside. Love is a gift you must never ignore. I can tell you what you get in the Game and what you may expect from those around you."

"You know I hate it when you get philosophical." She waited. So did he. "OK. So tell me."

"You deserve dignity. You know only deference. Deference is the combination of envy and fear that your father's money creates. Dignity is far, far better than that.

Something you have not yet understood. From the dignity you lend to others you will grow self respect and be ready for life and for love."

Chelsea hid her face in her hands as the tears welled up.

"Do not cry," Moses said softly. "Yes, there will be mountains of dishes to wash, sinks and toilets and floors..."

“Enough already!”

“...but there will also be friendship and laughter and learning and maybe... maybe even love."

Without a knock, a head appeared through the half-open door; a really cute boy with a sad attempt at a beard and dirty blonde hair.

“There's a midnight frolick brewing over on campus at the Quad. Come on! Everybody's going."

“Frolick?” Chelsea stood up, blinking the tears away.

"Here." He stepped into the doorway and held out a red rubber nose. "You can wear this one, if you like. It even goes with your hair. I'm Todd. Across the hall." He gestured with his head. "I have several." He pulled another nose from his hoodie.

"I’m... Chelsea." She had nearly said Samantha. "I'll catch up with you there." 
Todd ducked out. Chelsea went to the closet door mirror and popped the nose over hers. The sight made her break into a smile. Her hair was tinted bright red, as a transition from the brunette dye she wore as Isabella. She would love to dance across campus with a passel of clowns right now, but a public frolic was the last place a girl on the run needed to attend. Probably a hundred videos from this would be uploaded to Junana by morning.

\section{$\S \S \S$}

Chelsea settled back on her futon and pulled the single sheet over her body. She was wearing a thin t-shirt and panties and wondered again who decided not to air-condition this house. She had been on the road today for nearly twelve hours. Her roommate, who she had not even met, was probably off with the others, frolicking over on the campus. Her phone alarm was set for six in the morning. When she closed her eyes it felt like she was back on the road. Her head still rang with the wheel noise and snippets of towns and fields rolled across her memory. She slipped in her earbuds.

"Simon here. I'm in Rio de Janeiro talking with Vanessa Menezes, who currently runs the childcare center of Grange 1753. Vanessa is the person who gave away the very first Shine stone. Then she worked with the Magisters to make these available across the planet. Hi Vanessa, I have three minutes to learn about how you invented Shine stones. What was the first stone you gave to someone?"

"I was struggling with my first badge. I wanted to learn to use the makerbot, but I needed to learn to program, and it all seemed so..."

\section{“Complicated?”}

"Exactly. But an older man who was a master programmer sat down with me on a Saturday and spent almost the whole day explaining the logic of variables and values and loops, and, well, everything I didn't understand. At the end of this lesson, I knew I could do it. I was so happy. Of course I thanked him, but I wanted to do so much more for him. He had given me his entire Saturday. I had a glass marble in my pack. I'd found this on the street. So I gave it to him and told him I would give him some of my Shine when I was next on Junana. Then I thought: what if the gift of the marble could be just like going to Junana?" 
“The stones make Shine a physical transaction. I don't know how many are given away on any day, but it's got to be millions."

"There are about a hundred billion in circulation. Every stone has an ID which is also its hashtag. When you get a stone it adds to your Shine. When you give it away, that Shine goes with it. I like to think the gesture itself adds a bit of joy."

"I'm glad the Magisters saw its logic."

"The rules around the stones are simple: You must pass it forward in ten days or lose the Shine you got when you received it. And, you cannot receive the same stone twice..."

“... And you can't pass it on to any of the last three people you gave stones to. I find it really useful as a way to give Shine when I'm traveling or on frolicks. Particularly with strangers." Simon said. "I end up looking for generosity and finding this all around me. This teaches me new ways to be kind."

She continued. "Shine needs to be shared spontaneously whenever possible. Somebody does a kindness-a stranger lends her umbrella to a child in a storm, a customer returns extra change given by mistake, a student helps a peer solve a problem - the person who is helped or anyone who sees this can now step up and offer a bit of their own reputation as a gift. A billion small kindnesses can change how the planet spends its day."

"What's new with Shine stones?"

"Some gumis let their members buy special meal stones with jikan. They can trade a stone for a meal at any local gumi cafe. But they can also give a meal stone to someone on the street who looks hungry, and skip a meal themselves."

"Very cool. There are a lot of hungry people out in the rest of the world. Who did the app?"

"I programmed the first release. Others made it way better. Adding the holochain made it fully accountable."

“That's impressive! Here.”

"I told you I like to program. Wow, a Shine stone from the Grand Meister. I don't think I'll be giving this one away." 
"You'll lose that Shine."

"But memories are also good to keep. And because you are so sweet, no toilet to clean today."

“Thanks Vanessa. I told you Shine stones come in handy. This is Simon signing off from Rio."

\section{THIRTEEN}

The annual trek over to the desert for Burning Guy had become routine, as if packing half a dozen large Noël vans with an assortment of brightly colored tents and flags, banks of LEDs, hoops and fire sticks, costumes, body paint, and glitter, lube and kerosene, and all the food and water that Grange 829's Gumi 13 staff members would need for a week could become routine. Nick was driving the lead van with Megan riding shotgun.

They were well up the 101, listening to a vintage house track, when Nick spoke.

"I've decided to go on walkabout." Like he was pointing out a deer grazing in a field.

Megan heard him clearly, but to buffer her response she said, "What? Want to say that again?"

"After Burning Guy. I'm taking six months. I want to go to Europe. I need to get my mind clear."

"Something's not clear in your mind?" Junana had become littered with couples who broke up when one of them went on walkabout. Just announcing a walkabout was a commonplace exit move. 
Nick looked straight ahead, and glanced over to his driver's side mirror. This went on for too long.

Megan felt her throat tighten up. In her thoughts, she was fishing for any hints she might have missed. For things she did or forgot to do.

"It's really not like that Meggie," he said.

"Like what?"

"I'm not running away from you, from us. I'm just..."

She watched him struggle with the words, her lips pursed firm against the urge to cry.

"You and me." His voice crackled. "We've been together since I was seventeen. It's been the best part of me, being with you. I want to spend my life with you. I really hope you feel the same way..."

“That's not what 'walkabout' means."

Walkabout was a personal journey, no couples allowed, and no questions asked. For many, the journey included serial romances along the route. In every grange there were those who would welcome someone on walkabout with much more than a free meal. "What happened to teaching English?"

"I'm a Sixer now. I have to take some time and space to figure out what that means for me."

"For 'me."”

"Now I'm being selfish."

"No more than usual."

"Sounds like you want me to leave."

"I just don't ever want to have to keep you. Nicky, you are always free to go."

Some miles of silence passed.

"Free to go," he said. "But no guarantees for the return."

"That cuts both ways. I still love you. I always will. So go and fuck your way across the continent. I'll be fine..." 
She looked away out her side window. "...plenty of interesting people on walkabout come through Santa Barbara."

Nick gripped the wheel harder, frowning at the image in his mind.

"When do you leave?" she said.

"Week after Burning Guy. I got someone to take over my classes at the High School."

"You picked a great time to tell me."

"I thought you should know right away. I only decided yesterday."

Megan focused on the passing vineyards out her window.

"At least you didn't just take off," she sighed.

“That's not me. And not us. I am coming back; it’s only for a few months."

The road sang under their wheels for nearly an hour.

Megan decided she was not so surprised. Almost everyone who becomes a Sixer goes on walkabout, if they haven't done so before that. It's not like he should ask her for permission. They've been a couple since they were both really young to do what they started doing. Deep into the Game, their coupling was intense and also casual. Maybe she's just angry she can't get away, too, and would not even be invited. She always used to go with Nick when he toured as a dancer. So he got through Level Five before she did. Damn it anyhow. She needed more Game time. If hookup sex were his goal, he could find other women in Santa Barbara. And she's confident he would tell her if he did. No, he's going off to grow in ways she cannot share. What scares her more than any other woman is the idea that he might come back and see her differently. Then again, not having him around might make her see him differently. Somebody has to stay for someone else to go. Her momma didn't raise Megan to be a "yes...but" kind of person. She had to find a way to get with him on this decision.

They had reached the Salinas Valley. Verdant fields were offering up their crops of broccoli and onions; their lettuce and tomatoes. Purple-hued hills tried to cradle this abundance.

“Many a trip continues...” she said.

“...long after movement in time and space have ceased.” He finished her thought. 
She nodded at him. “Too obvious?”

“Nah. I love Steinbeck.”

Looking out her side window she said, "I suppose you might up your game."

“What?" He looked over at her.

"Pick up some new moves." She turned to face him, and raised both eyebrows twice.

“What!?”

"Sure wouldn't hurt." She tried and mostly failed to look serious.

“My moves are classic.” He grinned.

"So you've been telling me, cowboy."

"I haven't heard any complaints."

"I'd say you've got the entry level badge down cold."

"I may not be a master, but I'm at least a journeyman."

“Really! I'm the one giving out badges here, and that's totally news to me."

“We'll see about that!"

"You've got a week in the desert in a tent under a summer moon to prove yourself."

“We could just pull over. You want to see my camel?”

"Keep it in your pants, Valentino."

\section{$\S \S \S$}

The RIND Corporation's fall economic summit had been a fixture for decades, attracting top industry analysts and government agency leads. The forecasts at this event set informed economic strategies and plans for the coming year.

"You see. This is why we're screwed." The speaker, a forty-seven year-old analyst from the RIND corporation headquarters in Los Angeles, punched the key on his laptop and 
an image of an AirCraft, dazzling in full sunlight over the city of Rome, appeared on the screen in the darkened room.

"Within weeks the FAA is going to permit these for flights within the US. We've held this off for years, but there are many within the administration that want to see it happen..."

Dickey Gronberg, Department of Commerce undersecretary, spoke up. "You've heard of global warming..."

“...sure, these things fly without the use of fossil fuels. That's not my point. Every AirCraft in service replaces a Boeing jetliner. Now a 777 will cost you two-hundred and fifty million dollars retail, employ a couple thousand workers, and make a real profit for a publicly traded company..."

“...and devour several hundred million gallons of jet fuel over its lifetime," Dickey injected.

“...These AirCraft are made from lightweight films, aerogels and nano-coverings. Their gondolas are molded from hemp fibre composites. It's hard to determine their actual cost, since they are made by factories run by cooperatives that trade services."

“They are insured for replacement value of only ten million dollars," Dickey said, glancing at the report.

The sound of the projector fan seemed to grow ominously in the silence of the room.

"You need to understand something." A different speaker stood and walked over to the screen, silhouetted in the projector's beam.

Cal Witherspoon, former military tech giant CEO and now head of RIND, blinked in the light. "The airlines will do just fine replacing their old jets with new AirCraft. The great issue here is where this new technology is being created, or, more precisely where it's not being created." He looked over at Dickey.

"The Bourse in Castalia is an international open design community," Dickey said. "If our corporations want to benefit all they need to do is contribute back."

Cal responded, "Between the Bourse and Technopedia, the market for intellectual property has dropped more than forty percent in dollar terms in just three years. The trend is even steeper." 
"At the same time, the number of open designs has more than quadrupled," Dickey said. "Innovation has always happened elsewhere. Now that elsewhere has a home." Enormous Shine has been generated in the process, he knew. This room would not appreciate that fact.

\section{$\S \S \S$}

"All the utensils can go in these trays to be loaded into the dishwasher. Any glasses and cups and small plates, and whatever fits go on these racks. Watch closely," Sally said. "See. You slide these into the machine, close the door, and push this button here. The light goes off when it's time to unload. Everything else you will hand wash. I know you've passed your safety test, so I'll let you get started. You here a half day or a full day?"

"Full day," Chelsea said.

"In that case you get a break in the morning, a half-hour for lunch, and a break in the afternoon. When I say 'break,' I mean fifteen minutes. So do your peeing and keep hydrated. You can snack on anything that's out in the snack room. Are we good?"

"We're good."

Sally put her hand on Chelsea's shoulder. "I should say how much you're going to like working here. The truth is we get a lot of turnover with the dishwashing role. People tend to get other badges and we never see 'em again. Frankly, it's shitty work, you ask me. Not many people take to it. A few actually love it; I guess it suits 'em. I tell you, if you stick it out and get a Journeyman badge, you've pretty much got daily roles anywhere you go. A lot of dirty dishes in this world. I'll check in on you later."

Chelsea wondered just what a Journeyman badge in dishwashing would include. She was certain she didn't give a single fuck. She popped in her earbuds.

“Simon here. I've now visited several granges in Baghdad. I'm taking a walk with Hakim who manages grange number 97341 in Sadr City. Hello, Hakim, I bring greetings from Castalia. We have three minutes to chat about your work."

“As-salamu alaykum. Grand Meister, I am honored.” 
"Wa alaykumu as-salam. And it's just Simon, please."

"As you wish."

"Sadr City is one of Baghdad's administrative districts, and a place where decades of war have shaped its streets and its population. How many granges are there in Sadr City?"

"I would guess more than a hundred, all sharing the same commons, with new ones opening weekly. Look around you. We now have paved walkways and green gardens. Children are welcome back on the streets. There are hundreds of gumi cafes and tea shops. We are survivors, here. Even though we might live among ruins, we refused to be ruined."

"In my travels I've seen this type of neighborhood-level civil society blossoming all over the planet. I've spoken with officials here who are enthusiastic about urban livability in Baghdad for the first time in decades."

"The state will, of course, take credit for the decline in crime and poverty. It will showcase the new buildings, and try to own the laughter of our children."

"But none of this has come easily, I'm willing to bet. Not when so many have historical reasons for fear and hate."

"We try to give them new reasons for friendship and hope."

"What about fundamentalist reactions?" Simon said.

"The leadership roles that women earn: these are often criticized by more conservative mullahs. No surprise there. The same mullahs despise the Game, mainly because they had no influence in it or about its use. What they really hate, because they do not try to understand, is that all our long-term roles are assigned by lottery. No patronage, no clan privilege."

"They lose their grip," said Simon. "What else is different?"

"We establish our granges; share our time and tools, earn our badges. We make our own clothes and phones and build our own factories. We use solar power to generate electricity and hydrogen and now we even build our own automobiles-without even once asking the state for help or for permission. Our sharing unions are fully sharia compliant, and self-funded. My grange is self-insured. We feed ourselves and our 
neighbors. We care for our children as a group. We grow and shape bamboo. We run clinics and small hospitals. I look out for my dachi brothers and sisters like I watch out for my own family. There are many, many orphans and isolated elderly in Sadr City. My mura and dozens of others have joined together to donate thousands of hours of jikan every month for elder care and orphanage work. No orphan who earns their shoes is ever turned away from becoming a member of one of our muras."

"I was told you used to be an imam..."

"I am an imam, and our grange is fully integrated with our mosque. There is nothing in the Game that tells followers of Muhammed, may his name be blessed, to do anything against his teachings. Not a single template."

“The templates do lead one to an increased level of self reflection..."

“...As does reading the Quran."

"I’ve talked with Christian ministers who run granges within their churches."

"My wife has a cookbook she loves. This book is called la Methode. It is not filled with recipes but with instructions on cooking techniques. I can imagine that many nonbelievers use this book. Some of these techniques explain about cooking pork. Should I burn this book because it shows how to cook a pig? Or because Christians also use it?"

"What about the templates. What if a new template does suggest something against your faith?"

"There have been several fatwas on these. As with diamonds in the earth and birds in the air, the templates were created by God to be found and enjoyed. Scholars have noted there are many, many templates within the Quran.”

"But not all of them..."

“Perhaps. As we are still finding new ones and discarding false ones, who can say?” “The Game gets more complex every year."

"Tell me Simon, do the new templates make your knowledge more difficult or more simple?"

There is a passage of silence, with only street sounds. 
"In a strange way," Simon said finally, "When I'm told of a new template, it often makes the rest of them more sensible."

"Perhaps when we have discovered them all, they will shine their own light of understanding on us, and every Threevey will be a Meister. I must apologize, I believe I have kept you longer than three minutes."

"It's been very enlightening. I'll take that thought with me. Thank you so much for your time Hakim. I hope to see you tonight at the grange manager's banquet."

"The pleasure has been entirely mine, Grand Meister. Please enjoy the rest of your stay. Allah be with you."

"And you as well. This is Simon signing off from Sadr City in Baghdad."

\section{FOURTEEN}

"Here is a ten-minute lesson of the Five Skillings," Amitabh said. "Each of these has its own template strand."

“The five what?” Joseph said.

“They are called 'skillings' because you cannot simply query them to know them. You must practice them for years before their wisdom becomes yours. Even the best gamers need to be patient and reflect on their meaning. Today you'll only get a quick introduction."

The Game began to weave a new query.

"The intellect is the home of curiosity and the province of memory," Joseph heard as a stream of video and audio underscored the message. "Language is the palace of poetry and the workshop of the mind." More images and poetry from a dozen languages. "The body is the first connection to the world. All other connections are built on the body." A montage of beauty and strength, of infants standing up and elderly leaning on their 
canes. "The internal voice is the only friend we have at birth and death. It is the backstop for all other actions. The ability to exist alone, to be guided and comforted by one's own philosophy, this is the primary skill that allows the individual to be social." A girl with long golden hair meditating in the sunlight next to a still pond.

A bhikshu monk walking along a rice paddy at sunset. An ancient naked sannyasin wading in the Ganges. "Social skilling creates healthy boundaries and openings for intimacy with others." A couple kissing in the park. Two boys with arms locked together. Scenes of meals and of dancing. Smiles. Laughter. Eyes aglow. Hands holding hands. Then Amitabh was back.

"We will return to the skillings many times. But you must contemplate them on your own. Soon you will be given some practices to help you build your own skills." He nodded and the screen went black.

Joseph stepped away from the device, jarred by the images still swirling through his thoughts. He could still remember the days before the Game. Days consumed by work, bruised with hunger, gentled through his amma's smile, steeled from his appa's reproach, and finally extinguished by sleep. Each day was like every day before the Game. Now each day was its own.

\section{$\S \S \S$}

Dickey Gronberg took his time getting from his seat to the front of the room. Each of the speakers before him had offered up the statistics and predictions for their sectors of the economy. None of them were optimistic. For the past several years, consumption in the global economy had been spiraling downward. They looked to Dickey to tell them when this trend would end; when the world would return to its senses and start buying what they were all selling.

The RIND assistant had queued up Dickey’s first slide.

"Let me start with the good news. The US federal military budget is relatively stable." Even though there hadn't been as much as a firecracker thrown from the mostlyformer terrorist organizations in some years. Dickey looked over at Cal Witherspoon. For decades Cal ran one of the biggest defense contracting consortiums inside the beltway. "However, the global arms market is down double digits again this year." He clicked to his next slide. 
The time-lapse graphic was titled "Granges in the US." Red spots blossomed like ink drops raining down across a map of the US. Dickey spoke. "Grange numbers are growing five times faster than Halmarts at their peak. Their global membership is already bigger than that of the Catholic Church." Dickey figured this was happening so fast because it was a second order phenomena from the Game and the Internet. The Game made people reflect on their surroundings and the Internet provided nearly instant lateral innovation adoption across the globe.

"The economy inside these granges looks a lot like that of a healthy developing nation, relatively high production and fairly low consumption."

Cal said, "Inside an increasingly unhealthy first-world state. How could this happen?" Dickey punched through a series of slides. Photographs of granges. "They are buying up retail and industrial sites almost as fast as these are abandoned. They also purchase foreclosed houses at auction and retrofit these to double their occupancy. They now have about fifty million acres under cultivation, including new urban farms. Virtually all of this property is under a conservation easement. They are thinking long term."

"Fifty million acres? That's only about five percent of the farmland in the US," said Hank Hopkins from Monsanto. "Still we are seeing a definite slowdown in the grocery sector."

"Two years ago they owned one percent. You do the trend. Every grange in the US subtracts almost forty million dollars of sales from the surrounding economy and replaces this with only five million dollars of real income spent inside their own. This effect is most evident in high-consumption countries, particularly here in America. In a place like India, it's a wash." Still a subtraction, Dickey knew. A pulling away from the rest of the world.

"No wonder retail is in the shitter," Cal said.

"Retail here. Manufacturing all over Asia. These people are making their own appliances and computers, their own cars and clothes. They own their banks and they self insure. They sell to each other and never advertise. They are buying up hospitals."

Dickey clicked to his final slide. "Outside of China, where Beijing has managed to keep a lid on, we can see a point within five years, maybe sooner, where the central economy of the planet will take place within the grange system."

"How do we stop them?” Cal said. 
Dickey shook his head. "The smart money is on joining them. Plenty of multinationals are also competing for bids in the demand and supply economy."

\section{$\S \S \S$}

“Dr. O’Hara?” The voice called out faintly from the open doorway.

Scratchy was hunched over his laptop typing.

“Dr. O’Hara?” More loudly.

Scratchy stopped typing and seemed to be contemplating something out the window.

“Dr. O’Hara?” With some urgency.

"What is it?" Scratchy looked up. A young woman in black shorts and a Yanagi University tee shirt was standing in front of the open door of his office. He slipped on his glasses. She would be the new recruit. He could almost remember her poster from the conference in Hanoi. Something about rapid horizontal scaling data networks.

"Well, don't just stand there." Scratchy motioned her forward. "Next time knock once and come right in. You have something I need to know, well, then I sure as fuck want to hear about it."

Thuc Huynh walked up to the desk and set the little beacon on it. "I found this behind my bookcase."

Scratchy leaned forward and picked it up. "Any idea what it is?"

"I know exactly what it is. That's the problem. It has no business in my office, unless you put it there."

"Some kind of signal relay, I imagine." It was the size of a large shirt button, but somewhat thicker. He grabbed up a watchmaker's screwdriver from his desktop and pried it open. "Battery operated. Bluetooth?"

"Yes. Low power, lasts for years."

"A bug?"

She nodded. "It would need transmitters. Probably hidden in the laptops." 
“That would be Nam, I suspect." Scratchy picked up his cellphone and typed on it.

"Bastard's been listening in on us ever since he left."

Tiny showed up behind Thuc, occupying the entire frame of the door.

“What's up, Chief?”

"Security breach." Scratchy held up the beacon. "We need to sweep all the rooms, and do a complete hardware diagnostic on our laptops. And now is good, but it's also too fucking late."

Tiny nodded and turned. He was shouting as he went down the hall.

Scratchy turned to Thuc. "Please forgive me, I have forgotten your name."

"It's Thuc. Thuc Huynh"

"Glad you're on our team, Thuc." He reached into his desk. "People come by and give me these, but I don't know what to do with them." Scratchy pulled out a stone, bright red. A Meister stone, one of only a couple thousand or so on the planet. Each Meister in the Game received one of these when they entered Level Seven. The stone carried enough Shine for a month of vacation at any grange. "I think you earned this."

Scratchy stood, as he had seen others, and took the stone in both hands. Thuc raised her two hands as though he was about to pour water into them. Scratchy placed the stone in her hands and she cupped them together and raised them to her forehead.

"I am honored," she said.

Scratchy smiled. “You're very welcome. I hope they aren't too rough on you. We don't get many new faces around here. That's why I hired you. This place is as inbred as a Scottish castle."

Thuc stood there, gazing at the stone in her hands.

“Anything else I can do for you?” Scratchy said. She looked up and shook her head.

“Then piss off."

$\S \S \S$ 
"You have to keep the rinse water clean and above a hundred and ten degrees."

"You know how hot that feels?" Chelsea said.

"That's why your gloves are thick."

"Which is another thing. I can hardly grip through them."

"That will improve with experience."

"I sweat inside the gloves. Look." Chelsea pulled her hand from the elbow-length black rubber glove. Her fingers were red and swollen. A crack in the skin was visible on the edge of her palm."

"Try to soak them in cool water during the break, and use some aloe on them."

“Do they get better?”

"The idea is to not let them get worse."

"Fantastic."

Chelsea opened the hot water tap and watched the thermometer on the edge of the sink. She popped in her earbuds.

Simon here. I'm at Dr. Lu's dojo and health center on Peak Road in Hong Kong. This is a traditional style building. The main exercise room is, let me guess, about a hundred feet square. At the moment, it's crowded with people getting ready for the morning class, which I'll be joining. A wall of French doors have been opened to a magnificent view across to Kowloon. I'm with Dr. Lu, who has agreed to tell me about his system.

“Agreed? Grand Meister, I'm delighted!"

“Thank you Dr. Lu. In three minutes, can you tell me how you came up with this exercise regimen?"

"I was a martial artist as a young man. Gung Fu, Taekwando, Aikido: I became a black belt in each of them. When I started teaching I discovered that the students who did the best had certain physical skills. I began to wonder how we might develop these skills independently from performing a martial art. For some years, I focused on tai chi, yoga, and Pilates. From these I developed a new warm-up routine for my martial 
arts classes. One day a woman asked if she could come in just for the warm-ups. Then her friends wanted to join. I began to offer a separate class based on these routines."

"With the small ball?"

"I discovered the ball early on. It's an effective tool to bring out flexibility and core strength. The ball grounds you as it carries you. It is a one-point connection to the floor and the world."

"The body is your first connection..."

"Yes. When the Game introduced the Five Skillings I was teaching in Hawaii. Many of my students were Gamers."

"So you began to incorporate the Game's intention with your class?"

"I didn't do anything. I had trained an advanced class who wanted to teach my methods. They were the ones who made the Game connection. The next thing I know I have a thousand students instead of a hundred."

“Then you did the videos."

"The videos say nothing about the Game. You can watch them. Someone decided to make the small balls available at Red Star Coffee Houses. In a month I had a million connections on Junana."

"I’ve been doing your routines for years, Dr. Lu. I feel more fit, more connected after each class. When I get busy and forget, I start to lose that sense of being, well, a body in touch with its surroundings." A loud gong noise.

“Class is starting," Lu said.

"I want to thank you for your learning and your teaching."

“Grand Meister, I have to thank you for sharing this time with me. Shall we?”

"This is Simon in Hong Kong. I'm going to join a class with Dr. Lu himself. Signing off here." 


\section{FIFTEEN}

The intercom chimed. "There's a Zeus agent here to speak with you."

"Send him in," Dwayne settled back.

The man taking the long walk through his inner office was young, mid twenties, dressed in expensive looking grey slacks and t-shirt, probably Italian. Clean shaven, light brown hair combed back.

"Who the hell are you? Where's what's-his-name? Dick? Harry?"

"Harry."

"Yeah, right. He should be standing here." Dwayne pointed at the floor in front of his desk. "I got another bill from Zeus last week. It's like I'm putting Harry's kid through Princeton."

"I'm Peter. Harry suggested that we talk."

“Unless you are hiding my daughter in your pocket, I don't see we have much to talk about. Is this Peter as in 'Harry,' or do you have a last name?"

Peter sat down in one of the plush chairs in front of the desk and pulled a slip of paper from his jacket. "Peter Bishop."

"So, you're not an operative."

"No. I do believe that you will see your daughter again, just as soon as she wishes you to. Probably not a day before that, unless you want to spend a lot more money and time on this than you already have." He set Samantha's letter on the desk.

The letter arrived by mail a week before. There was an outer envelope with the stamp and Dwayne's Hope Ranch address hand written on it. Inside was another envelope with Samantha's writing. Dwayne immediately called Harry, who told him not to touch it until they could examine it.

The letter was in her handwriting. The envelope, paper, and pen used could be found at any Rite Aid pharmacy. The only fingerprints and DNA on the letter and envelope 
were Samantha's. There was a trace of food residue that was probably from a blueberry muffin.

"Hi daddy" she wrote. "Your Sweet Pea is doing great. I'm healthy and happy. I'm learning a lot and eating well. Seeing new stuff and experiencing life. I see the Rams lost to the Chargers again. At least the score was really close. I hope you and Sheryl are enjoying the fall in Santa Barbara. Gotta go. I'll write again next month. Sam.”

"Your daughter is fine, Mr. Mooney. She is safe and well cared for. She is not being held against her will."

"She's a kid, Bishop, she belongs at home."

“Think of it like she's gone off to boarding school. She's happy and learning, and, in a couple years, she'll be home...if she chooses."

"She could be anywhere. You can't tell me you know for sure some pervert's not got her locked in a basement."

Bishop reached into his other inside jacket pocket and drew out a sheaf of papers. He put these on the desk next to Samantha's letter.

"You'll see the similarity in the details and the lack of details of these letters. Each of these is from a kid who disappeared from home one day. All of these are now adults. We've interviewed them and their parents. The kids refused to talk about the details of their journeys, but they all agreed that their time was well spent, and that, for them, not being at home was the right decision."

"You're saying Samantha was unhappy at home? She was always happy, joking, laughing. She got everything she asked for."

"Maybe she had new questions, questions for which you had no answer."

“It's been several weeks. She must have run out of cash by now. How does she live?" "I would guess that right now Samantha, or whatever she is calling herself, is either studying or working in a grange somewhere in the US."

"A grange. Fuck. I knew it. How did they get her out of Santa Barbara? And if she's gone, then why not to...Patagonia?" He gestured toward the window, as if Patagonia were just on the other side of Montecito. 
"Zeus put her face onto a list of faces that would signal recognition at any border crossing." Zeus also had access to municipal and transit camera feeds across the US.

"Zeus interviewed staff and members at all the local granges. As expected, they were only too helpful."

"What the hell does that mean?"

"Zeus agents recorded more than fifty eye-witness sightings of her headed for about as many destinations."

Bishop had to laugh at that, inside. Sincerity is a Gift not a Given was a real bitch of a template if you were trying to get some information. Anybody who had earned their shoes in the Game knew that true information was too valuable to be handed out to strangers.

"Zeus put out the half-million dollar reward you agreed upon. The website hit three thousand suggestions before the end of the day."

When your search algorithm is poor, too much information was far worse than too little.

"She could have joined the grange right here, it means that much to her," Dwayne said. "I told her that. I have the text message still on my phone."

"Sometimes kids can be impulsive..."

"She didn't do this alone. Granges steal children from their homes? How does the FBI feel about this?"

"All of the interviews noted that these kids were free to return home any time they wanted. In each case, there were circumstances that pushed them away from their families. Four of these cases are ones I worked on personally."

"You got some kind of accusation to make, Bishop, do it now." Dwayne leaned back in his armchair and crossed his arms.

Bishop stood up and walked over to the window wall that looked out across the town to the nearby hills. He and his twin brother had spent most of their childhood in boarding schools and summer camps. For him, home was just another vacation destination. He turned back and walked over to the desk. 
"I'm not a social worker, Mr. Mooney. I am here as a consultant to answer any questions you might have as to the conditions of your daughter's self-selected new lifestyle. Zeus continues to search for Samantha. The firm is confident she is not in emotional or physical danger or distress. If she wanted to talk with you she could simply call you."

They both stared for a minute at the sleek Danish-designed burnished aluminum desk phone.

Dwayne slumped back in his chair. The one thing he never expected from Zeus was failure. He was sure they would locate her.

"Looks like I hired the wrong people. Maybe I should hire a bunch of raggedy-assed hippies out of one of these granges and let them find her."

This was not a bad idea, in its logic, Bishop knew. The only way to get information out of the grange was to dive into the mix. You put several dozen people on walkabout across the nation with orders to find Samantha, and you might get lucky in a year or two. By then she could already be eighteen.

On their eighteenth birthdays some of the other "lost" kids just picked up their original identities, reactivated their old Junana accounts, called their families and got reacquainted, if not always reunited. Others had good reasons to stay lost. Peter wondered which sort Samantha was. He hoped it was the former.

“I'm flying back to New York tomorrow afternoon. In the morning I can come over and answer any further questions. If you are satisfied, Zeus could place the search operation on automatic, keep listening for any credible lead or video hit, but not sending out operatives. You'll save a lot of cash that way." Bishop had the idea that would appeal to Dwayne. "You have the consolation of having hired the best of the best to find your daughter, and you have Zeus's sincere regret that it was unable to do so."

"How sincere? Are we talking refund?"

Bishop waited silently, smiling just a bit.

Dwayne said, "O.K. Tomorrow then. Same time. You can tell Harry that his services were disappointing. Make that extremely disappointing. Now if you will excuse me."

Dwayne waited as Bishop stood, nodded, and walked to the door. Then he grabbed up the receiver and punched the intercom button. 
“Denise, pencil in a 10 am tomorrow with Mr. Peter Bishop. He's the guy just leaving. Take a good look. By the time I get back from lunch I need everything the world knows about him on my desk."

\section{$\S \S \S$}

Her driver's license was bogus, that and the simple fact that she had not yet learned how to drive, limited Chelsea's choice of vehicles. She biked around quite a bit, but for longer rides, Chelsea checked out one of the grange's electric mopeds in order to explore Asheville's environs. She even wore the dorky helmet the sharing service offered.

On a free late-summer Sunday afternoon Chelsea went roaming. After a couple hours she spied a cafe with big neon "Cafe" sign, a painted sign that read Dandelion Cafe, and another neon sign in the window: "Eat Pie."

Sheryl never let Samantha go into these places. Sheryl had married Dwayne so as to not need to eat in working-class diners and fast food joints ever again. She hoped her children would never know them.

Chelsea parked the moped. She had a twenty in her pocket and a hankering for pie.

"What can I get you, hon?" The woman behind the counter, her face aged like a piece of fine elm, not a touch of work on it, in a pink uniform blouse with a badge that read "Irma", slid a menu across the counter when Chelsea sat down on the stool. The only other customers were a couple of old ladies in a booth.

"Hmmm. I need to try your cherry pie..." Chelsea pushed the menu away.

"You want that heated up?"

"Sure."

“To drink?”

"Hmmm. What goes good with pie? I'm thinking a double macchiato."

"A what?"

"You have..." Chelsea looked across the counter for the espresso machine that was not there. Her mistake. 
"We have coffee. Made fresh every morning in the big urn there. It's a bit stronger and nastier at this time of day, so you might want to add some cream. You can pretend it's a... what did you say?"

"Macchiato."

"Sounds like an Italian lounge rat.”

"I’m good with just coffee."

When Irma came with the coffee, Chelsea reached for the mug and took it in both hands. She winced from the heat and quickly set it down. She blew into her hands to cool them. They were still swollen from her work.

Irma appraised her thoughtfully.

"I have some witch-hazel lotion you can put on those." She nodded, her eyes on Chelsea's reddened knuckles. "You do laundry?"

"I'm a dishwash...I mean I wash dishes," Chelsea said. A mix of disgust and ironic pride flashed in her thoughts. Just saying the words made her situation seem both unreal and too-real. "Well, for now I do."

Irma looked across the room and spoke louder. "You should talk with Debbie. She worked in the hospital kitchen for forty years."

"The first year is the worst, dearie," Debbie spoke up. Debbie owned a hairdo that might have been popular a few decades back.

Debbie's friend said, "After that, it's all down hill."

"That was my marriage, not my job," Debbie said. "I know I'm over the hill. But since I have no recollection of ever being anywhere near the top, maybe I tunneled through it."

Debbie shared a burst of laughter with her friend and they returned to their conversation.

Irma said, "Easy girls, you're scaring..." She set a piece of cherry pie on a thick porcelain plate on the formica counter in front of Chelsea. "What's your name, hon?"

“Chelsea." Chelsea picked up her fork. 
"You see, Chelsea, life comes at you from all sides. The real trick is not to back yourself into a corner. Better to give it a good run while you can."

"You seem to be doing well. This is a cool place you have." She took a minute to look around again. The place could be a movie set from some '80s comedy: all shiny chrome, vinyl, and formica.

"You think I own this?" Irma rolled her eyes.

“Well...” Chelsea bit her lower lip. Another silly mistake.

"I do spend a good part of my time here. It keeps me out of the apartment. Nine dollars an hour and all the pie I can sneak."

"Nine..." Chelsea's nose wrinkled. She rubbed it with the back of her hand like she was about to sneeze.

"I started at four an hour. That was before you were born."

“Why doesn't your husband...?” Too late, Chelsea noticed the lack of a ring.

Debbie called out, “Don't get her going, love.”

Irma turned away and with measured deliberation grabbed up a mug from the countertop. She poured herself a cup of coffee, seeming to make up her mind about something. She turned to face Chelsea and leaned back against the cooler.

Chelsea took a monster fork-full of pie. It was everything cherry pie should be, sour and sweet, with a flaky butter crust. "Wow," she moaned. At least she had been right about the food.

"OK, Chelsea. This is girl to girl." Irma glanced past Chelsea to stare at Debbie. Debbie drew her fingers across her mouth. No butting in. Irma turned back to Chelsea, who set down her fork.

Irma started. "Rule number one: Don't marry the first one you sleep with. Even if you screw him for years." Her voice was as dark and bitter as the brew in her cup.

"I..." Chelsea began. Irma raised her hand with two fingers extended. Chelsea clamped her mouth shut.

"Rule number two. Keep your legs open and your mind sharp for a while. Get some while it's there. But not like a silly bitch. Pay attention and have fun." A wan smile and 
then. "It won't last. So don't wait."

Chelsea nodded. She wondered where this was going.

"Rule number three." Irma looked Chelsea up and down. "How much do you weigh? One-thirty-five?"

“One twenty-eight.” Chelsea offered.

Debbie snickered, Irma shot her a glance.

"You need to hit one-forty or one-fifty before you get serious with a man."

"I’m never going to..."

“Yes, you will. Do it first, this keeps their expectations in line. Don't forget that he'll gain eighty pounds."

"Eighty...!" Irma raise her hand again. This time with all four fingers raised.

"Rule number four. You meet his mother, remember, you are also marrying his mother."

"What if he says..."

“...Oh, he'll tell you what an old bat she is, but she has already stamped herself deeply into his ego."

"But what if I really like the mom too?"

“Then snag that boy and don't let go."

Irma took a big hit off her coffee.

"Me, I broke the first rule and third rule when I was your age. I was single again after four years and twelve extra pounds. I broke the second rule for a whole decade after he left me. Said I was saving myself for the real thing. Then I broke rule number four when I turned thirty-three. The real thing turned out to be a royal pain, exactly like his mom. I had ten miserable years before I got myself free."

Chelsea waited a moment and took another bite of pie. She glanced up at Irma, who stared back at her.

"What about..." Chelsea dropped her fork on the counter. She looked stricken. 
"About?" Irma said

"I mean do these rules count for the guys too? When he meets my mom..." Chelsea's eyes widened.

"Your mom that bad?"

Chelsea thought a long moment, took another bite of pie. Thought some more. Sipped at the bitter coffee and set the mug down. "Yup." She let out a sigh.

"Well, you're in luck. With girls it's the dad to watch."

"Oh, shit," Chelsea whispered. Suddenly she was Samantha again, episodes where she humiliated her friends flooded back like a highlight reel of casual cruelty. Had she been psychically...infected by Dwayne? Possessed? Tainted in ways she'd never rid herself of?

Chelsea reached into her jeans and dropped her twenty on the counter. "Keep it. Thanks for the advice."

She spun off the stool and almost ran to the door.

"Have a good life," Irma said behind her. "At least give it a good try."

Her memories chasing her, Chelsea hopped on her bike.

\section{$\S \S \S$}

Dwayne Mooney took a final look at the dossier Denise had provided. Peter Bishop had been some kind of teen celebrity, but not as much as his brother, Simon. Simon was a full-blown culture hero.

In his late teens, Peter had been a drummer in a next-wave band out of Brooklyn, and later a photographer for a retro culture magazine called Me|eat. Then he married the daughter of a retired securities broker and started producing online video content. His wife, Freya, owned galleries in New York and Los Angeles specializing in feminist art. Dwayne punched the intercom button.

“Yes, Mr. Mooney?” 
"Says here that Peter and Freya Bishop have a little over a hundred million dollars in a bank in New York. How the hell did you find that out?"

“Um. I just Googled it. Their sharing union has an open balance policy.”

"What the hell is that?"

"All of its transactions are public. Every deposit, every withdrawal."

“That's the craziest thing I've heard all year. Why would anybody bank there?”

"'Transparency at the Source' is the template, I believe."

“Denise, I told you I don't want to hear about any damn templates. Especially not at a time like this!" He closed the intercom link.

Dwayne web-surfed over to the home page of the Freya Bishop Gallery in Santa Monica, which had just opened a new show titled “Marilyn's Monroe," which consisted of enormous closeup photos of women's pubic regions, the female pudenda, photographed from a side view. The poster photo looked like something a kinky mouse would want to plant a flag on. He returned his attention to the dossier. Peter and Freya had a baby son, named Alex. They lived up in old money country, Putnam County, north of Manhattan. Peter's brother, Simon, was some kind of grand wizard in the Junanabased Game.

Samantha's older brother, Greg, had played the Game in high school. Luckily, he went to Pepperdyne, where they don't allow it. He took a real job at Samsung Financial in Chicago. Greg always had a good head on his shoulders. Funny, no girl's laid claim to him yet, not even for his daddy's money.

For the past couple years Samantha had pretty much disappeared into her bedroom to play on her computer. At first, Sheryl was happy Samantha was missing out on sex and drugs, unlike the teen girls who hung around the Doral Casino and snorted coke in the cabanas. Dwayne was now thinking that a little sex, with the right boy of course, and maybe a bit of weed might have kept Samantha in town.

Occasionally people Dwayne's age, sometimes people he had known for years, would get hooked on the damn Game and become insufferably boorish. At the last

Pepperdyne reunion their class divided into those who were still fun-loving and rightthinking and the others who would go off together to jabber endlessly about "the Game.” 
Denise had included "Fourvey in the Game" on her resume like it was some kind of accomplishment. She had just two years of City College, but she was as smart as any assistant he had ever hired and had looks to match. She said it was in the Game where she learned how to learn. He made it a rule she couldn't mention any damn templates on the job.

Peter's brother Simon was one of the top players in the Game. Simon had been missing for the last four years. Not just missing, but wanted by several national law enforcement agencies for a wide variety of serious info-crimes. Simon was underground or even dead. Nobody knew where he was.

At nine-thirty AM the next day, Dwayne welcomed a new client. Gary Bennett and his wife Christine lived in the hills of Los Gatos. They had just purchased a beach house on Padaro Lane down in Summerland. He was on the board of some tech giants up in silicon valley, having cashed out of the telecom industry with a couple billion in stock.

Sean Rafferty had just done a series on FIX News about President Rogers pushing to bring back the death tax. Western Trust plastered magazines and TV with ads with this same threat. Dwayne had seen a big uptick in new clients.

Dwayne had to guide them through the protocols of the Platinum-level of the Pandora Security system. After describing for Christine how the encryption keys worked, he made sure they were both fully enabled through the biometric safeguards on their terminal to access their account information.

"Nobody has ever lost a penny using Pandora," he boasted. "Even so, your account is insured by Geneva Re for up to a billion dollars. And the encryption is NSA-proof. Not even your banker in the Caymans knows your account balance. All of the security details are in the manual."

He led them out through his carved rosewood inner office door to the Western Trust elite members' club that occupied half the floor. A full bar of the premium stuff on one wall, a baby grand piano stood in front of the picture windows. The executive restrooms with linen towels were theirs to use any time they came downtown. He handed them key cards for the private elevator and waited with them until it arrived.

"You have my cell phone number." Dwayne waived as the door shut.

On the way back to his desk, he figured his bonus from the past half hour would be around four million. 
The intercom chimed. "Peter Bishop is here."

"Send him up."

\section{$\S \S \S$}

"I don't think you're putting enough iodine sanitizer in the final bath," the manager leaned over the sink. "It's supposed to look browner than that."

"It's nasty stuff," Chelsea said, "and it stains like anything."

"It only works if you put enough in. Half an ounce per five gallons. If the color fades, put a little more in. And soak for a full ten minutes." The manager drifted away.

"Fine!" Chelsea grabbed the bottle and squirted a long dash of the brown liquid into the sink. She looked back at the wall clock and shucked her gloves. She dug her earbuds out of her jean pocket and slid them on.

"Simon here. I'm talking with Rusty Brewbaker at grange 279451 in Eufaula, Alabama. I have three minutes to learn about how they've combined a local church community with a full grange. Rusty. Thank you so much for giving me your time."

“Nonsense, Simon. We're all big fans here. Don't get many Grand Meisters out this way. We've got one sixer in the whole grange. I trust you'll be staying to supper."

"I would be honored. What I'm sure my listeners want to know is how you've combined your church mission with the work of a grange."

“I'm not the reverend, mind you, so I can't speak about more spiritual matters. He'll be back end of the week, if you're still in the region."

"I'm off again tomorrow. Give him my regards. Can you show me around while we talk?"

"Love to. We can end up at the chapel. There's a choir there wants to sing a song or two for you."

"I'm looking around and it could be any grange in any town in the US. I see transportation and tool sharing, I see maker and crafter rooms. There's child care and 
a kitty palace too. And greenhouses."

"We're growing almost half our food, between the grange and our house permaculture gardens."

"What else do you produce?"

"We've got a small factory other side of the Chattahoochee that makes farming equipment from the open machinery catalog. We sell to granges in five states."

"Do you all belong to the same church?"

"This grange is a cooperative run by the United Church of the Risen Jesus. We do expect our membership to be faithful to its ways."

"And its ways include sharing cars and tools?"

"Nothing more Christian than sharing what you've got with others. Not a single word of the Five Skillings goes against the Ten Commandments."

"You know, I’ve been in granges run by mosques that say the same thing about Islam."

"Is that a fact? I'll need to reflect on that."

"How about the Game? Have your members earned their shoes?"

"We encourage the use of the Game as a way for our members to belong to a wider society, and we've lost more than a few who have found our scripture-guided path to be too narrow for them, once they've been on Junana. But we've also welcomed others who are tired of being adrift in all the ways of the world, and who want a simple home, a happy family, good friends, and honest work to do."

"So people can leave when they want?"

"What's that over there?"

"Rusty, it looks like you are pointing back at the road."

"Anyone can take that road wherever it will lead them. And we pray the good Lord will keep them safe. Let's go inside. This used to be a Pontiac dealership, back in my childhood."

"We're in the old showroom, which looks a lot like the common room in any grange." 
"Hi, Rusty, is that..." A woman's voice.

“The chapel's back here. Hi Susie. Yup, it's him all right. He’s recording...”

"Sorry," the woman said.

“Rusty, I just noticed you've got public baths here."

"What, you think we don't bathe?"

"Well it takes a cultural shift for a lot of people."

"Jesus never said nothing against bathing. Besides, we're Baptists, the big tub comes in real handy."

Simon said, "Say, did you ever hear of the UCCC?"

“Can't say that..."

Susie spoke up. "Ultra Conservative Congregationalist Convention. My mom used to watch Reverend Gerry every Sunday."

“That's right. Gerry Bishop. Any relation?"

"My father."

"I knew it! Susie, the Grand Meister's a preacher's boy."

"Guilty as charged. Well, this is Simon, signing off from Eufaula, Alabama."

$\S \S \S$

Did he just say "Eufaula"? Chelsea remembered stopping off in Alabama for lunch at a Horse gumi cafe called Giddyup in Eufaula. 


\section{SIXTEEN}

"Hello, Bishop. Wasn't sure you'd be back."

"Mr Mooney," Bishop nodded. "I..."

"Stop right there. My mind is still made up. I'm going to find Samantha somehow, with or without Zeus."

"If she doesn't wish to be found?"

“Not her decision."

"Some people need to get lost to find themselves."

"Like that brother of yours?"

Peter Bishop's eyes steeled. "The essential task of a nation, like a family, is to take care of its own."

"What the fuck does that mean?" Dwayne settled back in his chair. If this guy was going to start spouting little sayings at him, the interview was going to be very short.

About a year ago Samantha began to say things, trite phrases, some kind of pop philosophy. She called them templates. He wondered if she had developed an attention deficit disorder or late onset autism. They would all be eating breakfast and she would look around the kitchen and say "Windows on Two Walls," or "KitchenWindow facing East."

After some weeks, he asked her what she was getting on about. "Templates, dad. All around us. This house is filled with them." It was as though she could not not see them, and having seen them, could not avoid verbalizing this. That and the hand movements she would do in the morning, sometimes at the table, until Sheryl laid down the law. "You want to spazz out, you do it where we don't have to look."

"How much exposure have you had to the Game and to the grange movement?" Bishop asked.

"More than I care for. We visited a grange the day little Sam ran away."

"And the Game?"

"I don't play video games. What's you point?" 
"You visit one grange and you see a small community of people sharing their belongings and tinkering away with maker-bots and chip fabricators. To outsiders, the place looks crappy, kinda chaotic. Like, well....

"Like the Salvation Army on steroids," Dwayne said, "Like kids playing with grownup toys."

"What if I tell you each grange is an outpost for a hidden nation, what you might call a new global Game nation."

“Game nation? How do you figure? Are they hiding an army somewhere?”

"They are the army. Every grange makes its own rules, but they also act in concert, and they are building their own economy. They have been very quiet for years, but I think they are about to make some noise. You see, they march to their own drum, but sometimes they manage to share the beat."

"How does this in any way help me find my daughter?"

"You mentioned my brother. Years ago, when the most powerful states on the planet decided they didn't like Simon stirring up trouble, releasing information and leading actions, he disappeared into this nation. How could he hide out for so long? Where is Simon Bishop? I'll tell you. He's home with his new family, his dachi brothers and sisters, and a world of new friends deep in the heart of the Game nation. And now your daughter is there too. Snug and probably happy. Where are the Snowdens of yesteryear, Mr. Mooney?"

Bishop watched his rant soar over the head of the quizzical older man. People who had never queried in the Game often got lost when confronted by a simple Level Two style argument. He was certain that Samantha had the knack and would catch his meaning, and the literary signal, and come back with something significant.

"Where are the what?"

“Did Samantha ever talk about Castalia?”

"Isn't that a brand of beer?"

“I see. Would you like to take a look at the capital of this Game nation?”

"For what possible purpose?" 
"Looking for your daughter might not be the best idea you've ever had. I can show you why."

“I'm a busy man.”

“This will take a few minutes. It would be better if we could hook up my laptop to a projector."

Dwayne pointed up with his left hand, while his right hand hit a button on the edge of his desk. Peter glanced up and saw a video projector descend from the ceiling as the windows in the room darkened.

\section{$\S \S \S$}

“Always do the men's room first. And put up the 'Do Not Use' sign, like this, or they'll come in and try to piss in same urinal you're cleaning. Take a look at that wall, will you? I can only think they have a daily contest that involves blindfolds and handstands. You need to wash all the walls around the urinals. Get into the corners. And mop the floors. And remember, while you're in here, a man is using the women's room. Standing up. I'll leave you to it. After you're done, initial the sheet."

Chelsea popped in her earbuds before putting on the gloves.

"Simon here. I'm talking with Count Jacopo Ottavio..."

“Hi Simon. Call me Jack. I'm really happy to see you again. We haven't spoken since you were in college."

"And so much has happened in the past five years. Jack and I are walking on the Via dei Calzaiuoli in Firenze, Italy. It's an upscale shopping street, but we're not here to talk about fashion."

"At least not about what you're wearing..." Simon was dressed in an ancient Chicago Cubs t-shirt and worn Wrangler jeans.

“That would take about three seconds, we've got three minutes. What's going on with Gamers in Europe? 
"You want to know about Europe? Well, the big news happened in Germany, Austria, and Switzerland. Thousands of mittelstand enterprises, you know, family-run businesses, have been converted into something like corporate granges with rolebased employment. They have committed to the WholeTale Game B economy."

“What's a corporate grange?"

"An employee-owned company, usually a newly formed cooperative where the original family owner receives an annuity for several years instead of a cash payout. The coops use work circles instead of dachi. Most of them also honor Shine and run housing and cafes like granges. They commonly share their technology through the open design framework at the Bourse on Castalia. This example has spread to other regions, from Scandinavia to the Mediterranean. I can show you small manufacturing centers right here in Firenze. They participate in demand and supply networks."

“The local newspapers are filled with stories of economic collapse. But you don't sound pessimistic. Why?"

"All the old-style economic statistics report a steady decline in output, employment, and productivity. If you went by these alone, Europe would be deep into a new depression. I've been working with Game B economists at their Guild Hall to capture the intent and the impact of this new economy."

“Can you give me an example."

"The logic of the sharing economy is to maximize access over ownership. The mostly unspoken goal is to live in the energy present. How good are we at meeting this goal? That's an economic question for which I would like to have an answer. Production and employment statistics are no use here."

"What can you do?"

"The WholeTale score is computed from several internal measurements. We can pull out the energy costs and the material sustainability indexes for all of the spimes manufactured and used by a grange, including water use and energy production. We know the amount of the daily energy flux for the planet, so we can compute a perperson quota. We can then offer a numerical grade. The top grade signifies that the grange is operating in the present; they use one day's energy each day. The next grade down says they are using up to a week's worth of energy each day. The next lower grade is for a month's energy, and the lowest grade is for a year's use energy per day." 
“Some people use a whole year's energy in a day?"

"Unfortunately, that used to be the overall grade of several nation states, from the US to France."

"But no longer?"

"Sectors of the Game A economy are still reckless with energy and resources. But the growth of the new economy is having a measurable impact. Most granges use a week's energy or less. About a quarter of European granges are now at or very near a day's energy per person per day."

"You call that living in the energy present?"

"It means you're not borrowing from the past nor colonizing the future."

"There are a lot of very expensive stores on this street. How much time do they owe the rest of the planet?"

“That's a question a Grand Meister might well ask. At some point soon we will have the answer for you."

“We still have some time. What's next?"

“The WholeTale score for a spime includes a cradle-to-cradle score for its materials.”

"Remind me what that is..."

"A cradle-to-cradle score of one hundred means that its materials can be entirely reused and, when used up, will become new raw materials or mulch to grow new resources."

“Nothing ends up in a landfill."

"Exactly. Most spimes with WholeTale scores above ninety have CTC scores at or near one hundred. We can use this CTC score to help granges authenticate their zero footprint challenge."

"What's that?"

"Beyond living in the energy present, some granges want to also have zero impact on natural resources. Again, this is a goal that Game A economic indexes cannot measure except as a negative." 
"Only it's a very important positive. Great to know. Hey, I think we're coming to the Duomo. It's magnificent!"

"Yes, that's it on the right," Jack said. "We can take a look, only..."

"Only what?”

“... well, I'm pretty certain they already have someone who cleans the toilette.”

"I'll try to restrain myself. Jack, thanks for your insights. This is Simon, signing off from Firenze."

$\S \S \S$

Peter Bishop completed the wireless link to the computer projector, which threw a cinema-quality image on the far wall, where a large screen had descended from the ceiling. He logged into Junana and then opened Castalia.

Bishop's default entry site for Castalia was just outside the main gate of the old castle walls, on the stone bridge over the moat. From here he could head south to CraftTown, West to the Bourse, or East, through the old forest, to The Zone. As a Sixer, he was not allowed into the Castle. That was the province of the Meisters of the Game.

The giant stone walls of the castle appeared ancient, veined with moss, mottled by lichen, their surfaces pebbled by the simulation of centuries of rain. In the sky, pendulous cumulus clouds sailed like galleons toward the West, their shadows darkened the hillside.

"Holy moly, where is this?" Dwayne leaned forward. A striped skink scuttled frantically over the cobbles and disappeared into a crack. Above them a hawk cried, and three crows rose from a tree to worry it. The ryegrass of the lawn, the glinting waters of the moat, with its black swans drifting on a subtle current, and the reflections of the castle battlements in the moat: everything looked as it should. Dwayne had seen screen images of video games, but this scene was somehow more authentic than he thought was possible.

Bishop rotated his avatar to the right and their view now centered across the wide, gently sloping lawn, the great maidan. The lawn was teeming with Sixers. Bishop moused to the settings, clicked a button and they all disappeared. Beyond the maiden, 
in a copse of trees was the Bourse, which towered over its surrounding woods. Its exterior was an exact replica of John Paxton's Crystal Palace. Nearly a million square feet of space inside a virtual envelope of glass and iron. From a towering pole next to the Bourse a full-scale model of the first new AirCraftfloated majestically over the structure where its design and its construction bids had been realized.

"Let's visit to the Bourse first. You're a business man. You might find it interesting."

"That's the big greenhouse down there?"

Bishop set his avatar on a quick pace.

"The geography of Castalia is a bit tricky," he said while they approached the building. "The virtual outdoor space, excluding The Zone, of course, is experientially about the size of San Francisco. Once inside any room, the virtual space can expand indefinitely. A simple door on a cramped hallway can open up to a room the size of a football stadium."

Bishop navigated the pathway nimbly and brought his avatar to the grand South Entrance.

“What are you interested in? Cars? Computers? Furniture? Fabrics?”

"I'll pick 'Cars for 200', Alex," Dwayne said and crossed his arms, settling back. The CGI was glorious, yet he wasn't sure why they were here.

Bishop typed in some commands and moused around, selecting some options.

"Let's enter." He moved through the door. Inside, on both sides of the entrance, for hundreds of feet in either direction, there were displays of cars, buses, motorcycles, vans, and trucks: each one up on its own dais. Hundreds of virtual people milled around. Videos splayed across the walls, and the crowd noise of several hundred avatars and dozens of amplified announcements echoed through the vast interior.

"This is where orders for fleets of new vehicles will be negotiated this week from around the planet."

Bishop strode to the central axis, to the great walkway that stretched from end to end. His avatar gestured. "Here is where the design for the Noël car was crafted, and where the bids for all the new factories were finalized." 
"We all know how that worked out. Auto stocks are still fucked." Fleets of Noël hydrogen fueled or electric battery-charged cars had become shared vehicles in cities and towns around the world. A quarter million of them replaced three million new car sales in North America alone.

Bishop stopped his avatar in front of a display of a full-scale, four-door passenger car. "That's the next generation self-driving Noël sedan." He looked at the sign. "It's got a 92 WholeTale score."

His avatar softly whistled his appreciation. He had read how the nitrophobic filter in the air intake reduced combustion pollution to nearly zero. The entire car could be remolded into new useful objects or composted, and its lifecycle energy costs were negligible.

Dwayne said, "You ever been to the North American International Auto Show? That makes this circus look like a Boy Scout Jamboree."

"Yes, but that show happens only once a year. This is a typical day. As I said, the interior of a space can be any size, I had dialed down my search to match 'vehicles'." Bishop held his hands out and pivoted in a circle. "If you wish, I think I can show you everything that's going on... Check this out."

Bishop typed in some more commands. His finger hovered over the Enter key. He looked back at Dwayne and pressed it.

They were still standing on the great walkway, only it was now as wide as a Parisian boulevard. The building had expanded in all directions, so too the noise, as hundreds of thousands of conversations echoed sibilantly. The space, larger than any interior space either of them had ever imagined, was filled almost to bursting with people and with an amazing profusion of things. Motorized farm equipment, plumbing supplies, computers, furniture, appliances of all sorts, bedsteads and armoires, foundry machines and maker-bots, bicycles and automobiles, rows of mannequins in broad range of attire, musical instruments and medical devices.

Overhead, a fleet of AirCraft models, from one-person racing zeppelins to mighty construction behemoths, crowded the ceiling.

"What you see here...," Peter shouted over the cacophony coming from Dwayne's surround speakers, “...is the collective enterprise of nearly half a million granges. Possibly a billion dollars in currency, GitCoins, swaps, or jikan are being promised or 
delivered this week for objects and commodities that meet the design and quality criteria determined by the granges." He moved his avatar in a slow circle, revealing the full extent of the spectacle. Even without the sound, the visuals were mesmerizing. It was like a hundred Grand Central Stations at rush hour.

"I can move that much money around any day right from this office." Dwayne poked his desktop for emphasis, and then swiveled in his chair and slowly poured himself a cup of coffee from the carafe on the credenza behind him.

"Well, that billion dollars will also displace a hundred billion dollars worth of goods not sold out in your marketplace."

Dwayne's mind was abuzz. He had expected nothing like what he had just seen. He was still trying to absorb the enormity of it. He turned back.

"Wait. Did you say half a million granges?"

Bishop shrugged. "Ballpark figure. Four years ago there were, maybe, five thousand. The numbers have been doubling every nine months or so. Some thousands of new ones are opening every month. In a couple years there might be several million. The Game has been around for a decade, only they are not just gaming today. They are making and sharing across the planet."

"Sharing? What's wrong with owning? Owning built this great nation. The world economy is shrinking my friend. All the better reason to take good care of your money." This was a standard part of his new-customer spiel.

"Actually, while not "growing" in your sense, the world economy has been increasing for years-improving its efficiency and ecological savings-only not where your bean counters can find it. Very few Bourse transactions involve any production, transportation, retail, or financial company that you can buy stock in."

"Even the banks?"

"Sharing unions. Customer owned. None of this is actually a black market. Everyone here pays their taxes. Much of the manufacturing is done directly by the granges and their factories. The designs are all open IP, and the materials providers are fully WholeTale."

"Which means they can't compete on the free market." 
"Sales of WholeTale quality goods have gone up over twenty percent a year for the past five years. In ten years it could grow..."

“...Almost two-thousand percent," Dwayne whispered. Dwayne made a mental note to downgrade retail stocks. "How come the Wall Street Journal never mentions this?"

"All of this activity starts with bids from the granges. And then there's the clothesline paradox."

"Which is...?"

"When you dry your clothes in an electric dryer, the economy measures the effect. Electricity is generated and used, the dryer machine depreciates a bit and will eventually need to be replaced, even the clothes lose some of their weight as lint. When you put your clothes on a line to dry, they get just as dry, only the economy doesn't measure this. In the sharing economy, objects are shared and designed to be reused until they get upcycled or composted..."

"Yeah, yeah. I'm not here for an economics lesson." Particularly not from an exdrummer who lucked out and married well. Dwayne wondered if a giant photo of Freya's snatch was up on the wall in Santa Monica.

"There is one other part of Castalia I think you might want to see," Peter said. He pressed a command and they were back at his entry point into the site.

Dwayne un-muted the sound. Below them a swan called out. Above them, the flags snapped in the breeze. Way off to the east was the border of The Zone.

The Zone's boundary with Castalia, a hundred-meter tall gray wall made to look like burnished titanium, ran a full kilometer across what had been the Eastern side of the original space, formerly demarcated by an unbroken stretch of dark oak forest. This forest now sported a single winding pathway to a red wooden gate with velociraptor skulls on its posts. The sign read "Checkpoint Charlie, enter at your own risk." The boundary made it appear that you were just entering another space within Castalia. Quite the opposite was the fact; when you entered The Zone you were automatically logged out of Castalia. Step into The Zone and you were on your own.

\section{$\S \S \S$}


“We don't throw any grease away here. It all goes in the buckets. They'll skim the debris and up-cycle the rest as bio-lubricants. Sometimes you'll be emptying and cleaning the deep fat friers. When the fat is just cool enough to handle, you open this tap. Well, first you get an empty bucket and put it here. Now you open this tap. There it goes. When you think the tub is drained, close the tap and get a cup of coffee. Come back and get the last of the fat out. Use that mallet on the wall to get the lid on tight. Make sure the tap is closed. The buckets go out back. Any questions?"

"What do you mean 'bio-lubricants'?”

"Nothing intimate, mind you, unless you're into that. Noël hydrogen engines need a fine oil. We supply one that's not petroleum based. OK, it looks like the fat's all drained. But give gravity a chance. Come back in a few."

Chelsea popped in her earbuds as she ambled over to the snack room.

"Simon here. I'm outside Philadelphia at the Fairchild estate called Somerset. I'm talking with Claire Fairchild."

"Hello Simon. Great to see you again. I think the last time we met was at the Reed College reunion some time ago. Why don't we take a walk around the grounds."

"Sure. This place reminds me of the English countryside. We are surrounded by large formal gardens behind us is a huge Georgian manor house, done in cut stone from a local quarry with white windows and doors."

"The garden is on the historical registry, otherwise we would be planting veggies," Claire said. "We do have a new perimeter bamboo forest."

"There is quite a bit of activity right now. The estate is being transformed into an academy for SpimeCops. Dozens of construction workers are busy remodeling the outbuildings. Claire, in three minutes, can you tell me what a SpimeCop does?”

"Three minutes. All right. SpimeCops are the metadata quality control experts for the entire WholeTale economy. Their work grows out of a decade of increasingly sophisticated life cycle analysis methods for spimes."

"What exactly is a spime?" 
"A spime is just a story of an object, just some thing, made by people. To become a spime, an object-from a potato to a supercomputer-must have its own life cycle inventory, the sum total of all its real costs, including non-renewable energy, raw materials, the waste and pollution created by its manufacture and use, and the costs of the systems and services surrounding its use. These are the whole-life costs for the spime. In addition, there are misery costs that capture the human trouble involved in their making, use, and unmaking."

"Misery costs?"

"You know: the human equation. How much time is spent, the working conditions, worker safety and satisfaction."

"So a spime is a manufactured thing..."

“...it could also be grown on a farm..."

"Right. But it needs enough metadata to describe all of its real costs."

"Exactly. The trouble of getting an official blue WholeTale label and a decent score is compensated for by a dramatic increase in the market value of the spime. As more consumers vow to purchase only WholeTale goods, the market is becoming more efficient and attractive, and also open to fraud."

“Manufacturers are faking these scores?”

"Usually they fake the metadata or they try to slip in components that resemble those with higher scores. SpimeCops are quality-control experts trained to evaluate the authenticity and provenance of any spime."

"How does someone become a SpimeCop?"

"First off, you have to be a Sixer. We are looking for people deep into the template logic. We've found these make the best investigators."

"So SpimeCops are really detectives."

"SpimeCops are allowed to enter any WholeTale factory or farm, any distribution center, any WholeTale retail outlet in the world, and interrogate the data from any spime, including interviewing workers and reconciling inventories."

“How many SpimeCops are there?” 
"To grow the global WholeTale commons, we need to have ten thousand or more. Right now we only have a couple thousand. This new academy will provide intensive training and support research into life cycle inventory measurements."

"Claire, our three minutes are up. Thanks so much. Anybody listening out there who is a Sixer, give some thought about becoming a SpimeCop. This is Simon, signing off for now."

\section{SEVENTEEN}

Peter Bishop's next Castalia destination was due south of the Castle. "The Bourse is where this new economy makes its deals. Next we'll visit CraftTown, where it manages its knowledge."

He started his avatar down a diagonal path across the massive lawn. He keyed an acceleration factor and they arrived at the edge of a grove of oaks. Ahead they could spy a wrought iron fence and a gate suspended from two brick pillars. On one of the pillars was a metal plaque.

“Bedford Falls?” Dwayne said.

“Let's take a look inside."

The road through the gate was of cobblestones. On either side stood a short street of mansions, their facades of brick and cut stone.

“These are the craft halls that I have some access to, as I hold badges for them."

"Looks like the Warner Brothers back lot. Forget this..." Dwayne settled back in his chair. "I've got a lot to do today."

"Wait one minute." Peter keyed some commands into his laptop. "CraftTown is the largest learning center the planet has ever known. I believe I can show you... yes. Watch!" He pushed "Enter." 
In front of them the street, several times wider than before, now stretched out for miles, the facades of the craft halls vanished to a point in the far distance. The street was pulsating with thousands of avatars, walking past and through each other as they made their way.

"Let me...." Peter selected another command. The crowds vanished. He set his avatar walking down the middle of the street. The buildings on either side were of uniform size but varied dramatically in their styles. Some recreated international style simplicity. Many clung to some original bavarian guild hall stamp. Others reached out beyond a Seussian vision of the possible. One was invisible except for a small smiling human mouth at shoulder level; full rose-colored lips opened on occasion to reveal even teeth and an electric pink tongue. Another had a cruelly bladed pendulum of dark iron that swung rhythmically in front if its doorway from a pivot at roof level.

"Each of these craft halls manages a type of knowledge and skill, from anthropology to zoology, from knitting to nuclear engineering."

“Looks like Crazytown to me. Let's get out of here.”

"Hold on a second." Peter bent over his keyboard. "Here." The street shrank back to its former width, with perhaps a mile or so of buildings on either side.

"These are just the academic craft halls. Everything that is taught at most universities today is also developed and argued and advanced in these halls. Master badges are open to anyone who wants to learn. Knowledge is no longer scarce. The limiting factor is, as it always was: time. This is why jikan is so precious."

Dwayne remembered that the kid, Fred, said he'd saved up enough jikan for a year. "Remind me, what is jikan?"

"Jikan is time, measured by the hour. Everyone has only so much. Even the richest person in the world."

“Right. Speaking of time. Your's is now up. I've got other things to do. You've got a hundred million in the bank. What are you doing working with Zeus?" He pushed a button and the room's windows became invisible again, the screen rolled up into the ceiling.

"I owe them." Peter raised his left hand in the sunlight. The little finger and ring finger were missing. 
“Ouch. I bet that didn't help your drumming career. Who...?”

"An intelligence agency, never sure which one, decided they could make my brother reveal his location. They had me in a room somewhere east of Sarajevo. They were mailing bits of me to my father." As if that would work, Peter mused. Simon has not spoken to their father in a decade. "My father-in-law hired Zeus. Two of their agents died getting me loose. So I agreed to consult on occasion."

"Sucks to be you. Your brother ever thank you?"

"Where is Simon Bishop?" Peter always loved Simon. That didn't make it easier to be Simon's brother.

“OK. Play it cute. Maybe they won't try for your ears next time.”

"You still plan to find your daughter?"

"Nah! You've given me some new ideas on that score." Dwayne had a fresh plan. He'd find a way to force the...what did Peter call it, oh right... "Game nation" to give her up. When he's done with them they'll be standing right here, begging him to take her back. Maybe he'd have Simon Bishop bring her in personally.

Dwayne stood up and came around the desk. "Let me show you to the elevator."

He took Peter's arm and guided him toward the door. "You and Freya should look into an offshore corporation for your assets. I could save you a lot on your taxes. These are troubling times, my friend."

"We're fine with our sharing union."

"Suit yourself. I have to tell you, there's lot of risk keeping your money where the government can get at it. And this transparency bullshit, that's going to backfire on you one of these days."

After Bishop had left, Dwayne went to his computer and Googled up his assistant's name. Sure enough, her bank balance was right there. Just over four thousand dollars. Dwayne made a mental note that Denise might not need such a big Christmas bonus this year. He punched the intercom.

"Denise, cancel my appointments for today and the rest of the week and tell the pilot to get the jet ready. Let our Manhattan tower staff know I'll be arriving. You can tell Lupita to take a week off." 
It was nearing midnight on Saturday when Todd's brothers pulled up to the curb in front of Chelsea's gumi house, just over twenty-four hours from when Todd had burst into the second floor bathroom to find Chelsea cleaning the toilet.

\section{$\S \S \S$}

"Jesus, Chelsea! It's Friday night." Todd had his right hand on the zipper of his fly, his left on his belt. "You should be out on the town somewhere, not scrubbing the fucking john. And I've got to pee."

Chelsea stood up, brush in hand. His urgency was palpable. "Fine. And you can finish up when you're done." She handed him the brush as she passed.

Closing the door behind her, she fell into a puddle of self-pity as she walked back to her room. It was Friday night. Back in Santa Barbara, she would be downtown or over at the Doral Casino: anywhere with music and laughter and people and fashion. She collapsed into her desk chair, fighting tears. The window was open to the balmy summer breeze. She could hear parties, multiple events from all over the neighborhood, their amplified music bleeding through walls and open windows, blending into a cacophonous summer symphony.

Todd appeared at the door. "Sorry about that," he said. "A bit rude."

"You're right. I'm lost and I don't know how to find myself again."

Todd came over. "I really don't understand why you're not out there. I mean, look at you. You're a knock-out. You could have any guy in the grange if you wanted. But here you sit."

Chelsea knew she couldn't confess her real reasons for not partying, how Moses had warned her that the people Dwayne hired would be scouring social media with their facial recognition algorithms. Way too many selfies out there in party-land.

"You wouldn't understand," she said. "I mean, everyone likes you." Actually, Todd was a bit of a screw-up when it came to doing household chores, but his clownish banter lightened up any conversation, so people wanted him around. 
"You're this enigma girl. We don't know why you got out of California, but we can see you're not real happy here, and we can't figure out why. So, we're all giving you 'space'. You're nice, you're hot..." His grin widened.

"Really? You think I'm nice?"

"I’m going to suggest something," he said. "You don't need to answer now."

He paused. Chelsea studied his face. "OK," she said. "Suggest away."

"Tomorrow evening my brothers are coming by from Durham to take me to Ka-Boom. You could come along. Just as friends, I mean. Nothing intended but good company. Get out of town for a week."

“Ka-Boom? You mean where people gather in the Texas desert to blow stuff up?”

"And to dance and get wild, and wear masks and feel free!"

"Masks?" A mask would solve the selfie problem.

"Well... sometimes they wear only masks. It is an adult event. I'm an adult. You're an adult." His smile became ambiguous.

"I am. Indeed, I am. But what about my job?"

"You get sick leave, right? This is how you can cure whatever funk you're in. You sure aren't getting better just sitting here. Text me in the morning. Let me know. We have all the tents and supplies, you just bring some clothes and stuff." He touched her on the shoulder and was out the door.

\section{$\S \S \S$}

The 1991 sky blue Cadillac Brougham d'Elegance towed a rented U-haul trailer filled with black powder and a makeshift cannon Todd's brothers, Jake and Randy, were eager to try. The Brougham's 5.7 liter engine gulped high-test gasoline at an impressive rate. The honey-golden plush leather interior was old but spotless. Todd and Chelsea settled into the back seat for the long run west on Interstate 40 . They chatted for an hour and then, around One AM, Chelsea settled back for a nap.

Around Four AM, at a travel plaza outside Knoxville, the brothers stopped to picked up Melissa, a stranger who had posted her need for a ride earlier in the day on Junana, 
with a note that she had cash for gas. Melissa was a husky brunette, heavy on the eye shadow. She wore a vintage Wonderbra under a translucent knock-off Johnny Was top and low-rider jeans cut off to reveal the bottoms of her bottom. She had a brusque voluptuousness that vibrated between knowing and needy. In her mid-twenties, she looked like thirty-something to Chelsea. This was to be Melissa's first Ka-Boom and she was stoked. Said so many times in the first ten minutes.

\section{$\S \S \S$}

The night was still warm, and they rode with the windows down. Randy, the current driver, decided to chain-smoke Camels, so Chelsea crouched against the passenger side door and kept her face into the wind. Upfront, the brothers each quaffed another five-hour energy drink, their third since Asheville. They tossed the bottles away and Jake punched the stereo power switch. Goatwhore cursed the night as they made the onramp.

\section{$\S \S \S$}

Sitting in between the women, Todd ceremoniously opened his daypack.

"Ladies," he announced, "Shrooms or Molly, your choice!" He pulled out two baggies and held these open. One held an assortment of pills and the other a dark mass of organic stuff. Melissa, giggling her excitement, grabbed from the baggie and gobbled up a couple Mollys with a swig from a pint of Jack she retrieved from the bag she had stored at her feet.

All this was new to Chelsea, who had only smoked weed a couple times on the beach. Chelsea's mind flashed back to a video from school about ecstasy making holes in your brain. So she took a pinch of slimy shrooms and passed them over to her right palm. She sniffed at them. They smelled like death. Like a corpse took a fart. A bolus of phlegm rose in her throat and she gagged just a bit and swallowed it down. No way could she put that shit into her mouth.

"I'm gonna need a hit of that stuff to get these down." She said and reached across Todd for the whiskey Melissa was waving about as she bounced to the music. Melissa hesitated, and then let Chelsea take it. At the same time, Chelsea quietly slipped her right hand out the window and dropped the fungus into the wind. 
"Cheers," she said, pretending to toss the shrooms into her mouth. She took a swig and managed not to cough as the liquor burned her throat.

"Whew! Holy shit, those are rank." She shivered and passed back the whisky.

"They'll still do the trick," Todd said. He tilted his head back and dropped a pill into his mouth, then he short-stopped the pint and took a pull. He glanced left and right at the women, grinning like a fool.

"Pass that up here," Jake said. He reached back and snagged the bottle.

Melissa protested once and then sat back, waiting for the E to kick in.

\section{$\S \S \S$}

The curb in front of the 24-hour Shell Station just east of Memphis was cleaner than its women's restroom, where Chelsea texted Todd to tell him that he and Melissa could fuck their way to Amarillo, but she was headed back to Asheville.

Chelsea had initiated this hasty comfort stop. Somewhere between Knoxville and Nashville she drifted off to sleep. When she awoke she looked over to see Todd sucking one of Melissa's boobs as she tugged vigorously on his erect dick. His jeans were down at his knees.

Chelsea closed her eyes and breathed slowly for a minute. She needed an excuse to escape. Anything would do. She grinned and leaned forward. This put her face beside the headrest of the front passenger seat. Above the death metal Chelsea shouted in Jake's ear that her monthlies had come early and she was concerned about the fine leather upholstery in his vintage car. She really, really needed to get into her bag in the trunk. Stopping real soon would be best. She pretended to be so, so embarrassed.

Jake didn't take the news well, on all counts. He had been planning to switch into the back seat at their breakfast stop, a waffle house west of Memphis. Jake had been eyeing Chelsea ever since she hopped her fine ass into the Caddy.

The Shell station was a scant three minutes down the road. By then, Todd and Melissa were in full rutt. The Caddy rolled to a stop at the pump. 
"Open the damn trunk," Chelsea said and bolted out of the car. Randy pulled the trunk latch and turned off the engine.

"Look at 'em go!" Randy spied the action in the back seat. He trilled like a stoat in heat and elbowed his brother's ribs. Jake gave him a wide grin. "I'm next," he said and stepped out to gas up.

Chelsea, bags in hand, raced into the women's room in the back of the station's convenience store. She locked the door and leaned back against it, eyes shut. After a time, Jake pounded on the bathroom door to tell her they were leaving.

"So, leave already," she shouted.

"You owe us for gas," he grumbled and pounded the door again.

"Tell Todd... well, just fucking go!" Todd was probably blazing too hard to even notice they had stopped. Well, that and with Melissa being all on top of him naked in the back of the Caddy.

Jake called her a cunt, kicked the door one last time, jiggled the handle, and departed. Chelsea waited.

Maybe ten minutes later the clerk, a teen, probably one of owner's sons, knocked on the door and asked her if everything was OK.

"Are they gone?" she called out.

“Long gone.”

\section{$\S \S \S$}

The morning sun was a glimmer in the East when Chelsea flopped onto the curb and opened the game on her phone.

Moses appeared and gave her the greeting. He stood and waited for her to speak, his face a grim mask.

"I kinda screwed up," she said. 
"You're probably the first human to ever do that. Please tell me you are safe."

She nodded. "I'm good. I do need a ride back."

Moses's face spread into a wide grin. He closed his eyes for a moment, then he opened them. "A self-driving Noel will arrive in fourteen minutes. You can nap in the back."

"We need to talk. Sometimes I have no idea why I do what I do."

"You are sixteen. It's a time when emotions race ahead of judgement."

"I should have listened..."

"No! Well, yes, certainly. But better that you take some chances and begin to listen... to yourself. At some point you must become your own best friend and advisor."

"I have you."

"You do. Only I am not, you know, human." His avatar morphed into a bat-eared fox and raced clear out of view to the left of the screen. Chelsea let out a sharp laugh and closed her phone.

For the next fourteen minutes all she could think about was the deeply disturbing notion that, had she picked the ecstasy instead of the psilocybin, she might still be in that Caddy, getting fucked by Todd and Melissa, and, about now, probably Jake.

\section{$\S \S \S$}

Ninety-five percent of the job of running cyber security for a major global financial firm involved policing up the stupid computer tricks that employees pulled. The level of digital foolhardiness in the C-Suite was particularly astounding.

Narendra Prasad, Ph.D. had been abruptly summoned to a conference room upstairs. His guess was that some vice-president had forgotten his email password and login yet again. After a wait of nearly forty-five minutes, the door opened. The man that entered gestured at Narendra to stay seated and flopped down on the armchair at the head of the large oval table.

“Dwayne Mooney," he said, "You must be Prasad. Don't get up.”

“Dr. Narendra Prasad.” 
Mooney was dressed in a fine suit that fit him precisely. He jutted out his hand and checked the time on a large gold watch. Then he leaned back in his chair and put one shoe up on the table. "I only have a few minutes, so I'll cut to the fucking chase. I understand you are the top honcho nerd in this building."

"I run the Western Trust data and web servers and digital security." Narendra had no idea who this fellow was, but the name Mooney rang a small bell of alarm.

"You know about that game some people play?” Mooney said.

“The Game on Junana?" Narendra had failed to keep the Junana mesh off the company's intranet. He hoped this would not be yet another lecture on the need to prevent employees from playing.

"That one. And that place where they all go. You know, the castle..."

“Castalia.” Narendra nodded, not sure where this was heading.

“Exactly. I'm looking for someone with the chops to break the Castalia website."

"You want to hack Castalia?" Narendra said. He smiled, clamping his teeth to keep from laughing out loud. Clueless was too good a word for this one.

"Not destroy it." Unless I can, Dwayne considered, which would be fucking awesome. "Just hold it for ransom until they give me back my daughter."

“Castalia has your daughter?”

"It's a long story," Dwayne said. "Which you have no need to know."

"For how long do you wish to keep Castalia offline?"

"I'm sure they'll be cooperative in a matter of days, maybe hours." He imagined his phone ringing. "Daddy, I'm so sorry..."

"Mr. Mooney, I'm pretty sure that hacking into someone else's system is not actually a part of what we do here. We protect our own system from other hackers." And from idiots like you.

"I didn't expect you to do this alone, Narender. What I hoped was that you could connect me with a top flight, triple-A rated, totally badass hacker, who I could pay an appropriately enormous amount of money to do this one simple fucking thing for me." 
"I see. You want me to give you the email of a hacker with the skills to take down Castalia, for 'just a couple days'." Narendra had fielded his share of unreasonable technology requests from digitally naive executives in his day. This was the topper. "Only if you're interested in continuing to work at Western Trust." Dwayne smiled his fuck-you-with-a-stick smile. "I assume you would also play a small, but important role in this. I could not trust some total stranger with my daughter's well being."

Narendra's face blanched. Since their recent move into a SoHo condo, finances had been tight around the Prasad household. Unemployment would not be fun.

"Of course," Dwayne continued. "There would be something extra for you too. As you said, this is not a part of your job description."

"If I am to find this special cyber-criminal, it will likely mean I will need to travel into The Zone." He meant into areas of The Zone where he had never planned to visit. "It's more than likely that they will ask to be paid in GitCoins."

"GitCoins, shekels, simoleans, whatever. I can get you what you need. How much do you think this will cost?"

"In dollar equivalent?" Narendra stopped to think. Perhaps a large enough amount would dissuade him. "Mid eight-figures, I would guess."

"My thoughts entirely," Dwayne said, glancing at his phone. "How soon can you find this guy?"

“Wouldn't it be cheaper to spend this kind of money on people who can search for your daughter?" Not to mention a lot safer.

"Tried that. Now I'm looking to cause some pain and see who screams."

"You may not want to know the people who can create this kind of pain." If there were even one person on the planet who might be able and willing to do what Mooney asked, he would be found deep in darkest reaches of The Zone.

Narendra's day job kept him from spending much Zone time. A couple summers ago he had paid to be part of a convoy from the Castalia gateway to the New Tokyo township. Now he can log in directly to New Tokyo. Narendra occasionally dropped into Furbidden Planet, a cosplay bar, his avatar dressed as a playful koala. 
“Believe me," Mooney said, "I’ve met people who would make a Marine Corps drill sergeant drop his load."

"If there is such a person, and if I can get to where I can talk to him, it could take some days. And I will need some GitCoins to help..." He figured he would need to leave the cozy confines of New Tokyo and cross the wide, dark, wolf-infested hellscape of the open Zone, over to WestWorld, the toughest virtual town in the known metaverse.

"Grease the skids, sure kid. Give my personal assistant upstairs an account number and I'll set you up. I'd love to stay and chat, but I've got dinner with the president of FIX News." Mooney stood up and pointed at Prasad. "Don't disappoint me. Oh, and keep all your receipts." He turned and was out the door.

\section{$\S \S \S$}

Amber recognized an ongoing Game fugue state when she awoke and glanced across the room. Her roommate was leaning against the bedroom wall with her legs still in her futon sheets. Chelsea was hunched forward, and she murmured into her headset while she typed as fast as she could on her laptop's keyboard.

Amber sat up, stretched, and started her brain-wave exercise. Something was wrong with that one. A couple nights ago Amber woke up in the dark to hear Chelsea sobbing into her pillow. The next morning Chelsea said it was just a sad dream. Anyhow, she didn't seem as much depressed as displaced. How she ended up in North Carolina washing dishes was unclear.

Chelsea said she wanted to get out of California, go to some place more real. Like nobody washed dishes in California. Her awfully thin Junana profile listed her as eighteen. She was still a Threevey, even though she spent much of her free time on the Game. She didn't show much Game knack yet. But she wasn't stupid, she could hold her own at table conversations. Plus, she was straight, and not a single tatt. Not even on her back. So weird.

Amber asked her guide to ask Chelsea's guide if there was something she could do to help. All Amber's guide said was, "give her some time and space and she will find her delight." This advice was way too fortune-cookie. Like nothing he ever said. Something was wrong. Just my luck to get a roommate who was broken, she figured. 
Amber showered and dressed; but instead of running straight off to their grange for the first Master Lu exercise class of the day, she grabbed a latte and a couple crullers at the nearby Red Star and returned with these.

"Don't forget, we're having the harvest picnic this afternoon," she said, setting the goodies down by Chelsea's futon.

\section{$\S \S \S$}

Chelsea glanced up at her roommate, who had just delivered some coffee and donuts, smiled and nodded her appreciation before the Game play drew her back to her laptop screen. She made a mental note to give Amber a shine stone that afternoon.

Harvest time was a new concept for Chelsea. Until this year, Chelsea's life had been centered on school terms and vacations. If she were back in Santa Barbara, she would be at Laguna Clara School, resisting her mother's vision of her as a cheerleader. When she first met Dwayne, Sheryl was a cheerleader at Pepperdyne. You don't get to be a college cheerleader unless you were something of a cheerleading megastar in high school.

Harvest season was a busy time for all the granges in this part of North Carolina. Picking and pickling, carving and canning, storing up the bounty for the next six months: hundreds of gumi house gardens and grange farms need to be harvested. The produce would be sold at the famers' market, or to local gumi cafes, or sent to nearby cities in exchange for other goods, from CPUs to MakerBots.

Plenty of firsts in Chelsea's life these days. First roommate. First job. First time with no TV to watch. Sheryl always kept a couple TVs on, usually tuned to FIX News. Nobody here seemed to care about keeping up with disasters across the planet or the latest political scandal. The rest of the world would need to fend for itself.

First badge: entry level dishwashing. First doubts about how fun and happiness were linked. Lots of seriously happy people here. Working really hard. Still having fun. First friends who didn't look at her and see her dad's money. Chelsea had manufactured a phony story about escaping from California to "get real". She could not share the irony of her phony biography. Her housemates and dachi spent a lot of time in conversation. Chelsea struggled to catch up with their knowledge of design, art, social theory, cultural anecdotes and travel knowledge. The others brought in tales of their family 
lives in the rest of the world, stories of trouble and poverty that only alienated her further. She was quiet about that time Sheryl found a mouse in their Hotel Excelsior suite in Rome, or the occasion where Dwayne took the helm of his yacht and rammed Stearn's Wharf.

Garret was a Rat dachi mate who also lived in her house. He volunteered as coach for the dachi's ultimate frisbee team. As soon as Chelsea mentioned lacrosse he had her pegged as a cutter for their team. She refrained from telling him she had played a lot of ultimate in Santa Barbara at school and in hat tourneys at the beach. She figured to surprise him. The Rabbit gumi had its own internal ultimate tournament, with the winning dachi playing the other 11 gumi champions to see who would represent the entire mura at a regional tournament held on the Saturday after Thanksgiving. Her dachi participated in the Great Games, but without much enthusiasm or success. They were more into frolicks, dance nights, Maker Faires, badge bashes, and the Tennessee Burning Guy.

Chelsea's dachi ate at least a couple meals together every week at a Rabbit gumi cafe, called Fiver's, downtown. They organized movie- and concert-going nights, hikes in the nearby state parks, and annual trips to places like New York or Disneyworld. They had a regular table at the local Red Star coffee shop. When possible, they completed their grange volunteer jikan as a group. They hosted Rat dachi members from other granges on walkabout, sharing their rooms and springing for coffee, and they pooled some of their shine and offered this to one or two of the grange badge masters who had helped them the most over the year. Of its twelve members, Garret was the oldest at 55. The youngest was a fourteen year-old Threevey named Audry, who lived in a foster home. Half were under twenty. Mick, who was a fine carpentry Master badge holder, already had his Sixer yellow blouse.

The cafeteria where Chelsea worked produced a perpetual supply of dirty dishes. Even dishwashing had its own entry level badge. Scrape, wash, rinse, sanitize. Repeat for eight hours and go home exhausted.

"You're going to be doing a lot of different jobs in your life," Sally, her supervisor, said to her. "Probably going a lot of new places. You get tired of doing dishes, you might consider a Journeyman level badge in food prep. You can step into any gumi cafe on the planet and trade them jikan for food."

"I can't believe that people do this their whole life," Chelsea said, regretting it immediately. "I'm so tired every single day." 
Sally looked at her not unkindly. "This is good work. These students deserve real food. I spent twenty-five years working in fast-food joints that served sweetened-up crap to poor folk who had no time to even cook a plate of rice. People who were working three jobs to pay the rent and their medical expenses..."

"I didn't mean..."

"You need to understand something," Sally said. "Everybody does dishes before they figure out something better to do. Then they go do that. You gotta use your unhappiness like a fever that can focus your desires. Until then, I need you to work on them pans piling up in your sink."

Her roommate was nice enough, but they hardly saw each other. Amber worked the swing shift as sysadmin on some of the University's servers. She was close to a Master level chip fabricator, and had several other badges. She also had some sweet tattoos on her back and legs, and she spent a good amount of free time jacked into The Zone. Amber was usually asleep when Chelsea set off to work at seven, and away when Chelsea got home in the afternoon.

When she gets to Level Four, Chelsea will have some free-for-all time in the Game. She can roam the virtual landscape of the largest computer the world ever created. Anywhere outside of Asheville would do.

\section{$\S \S \S$}

"How much this time?" Dwayne asked. He forked a bloody crimson slice of rare Romanian beef into his mouth and dabbed at his chin with the linen napkin. He smiled as he chewed, savoring the meaty goodness. Some years ago, Dwayne had finally been voted into the Valley Club, after a considerable contribution to their clubhouse remodeling fund. On his very first day there Dwayne got bitten by a tick. Little fucker climbed under his shorts and latched tight onto his taint, locking its powerful mandibles just south of his balls. By the time Dwayne realized it was there, the tick's blood sack was almost the size of a ping pong ball. Dwayne first thought he had accidentally slipped a golf ball into his briefs instead of his pocket. His scream in the bathroom brought Sheryl running. The midwesterner in her took hold and she managed to singe it with a hot match head until it released its grip and dropped on the tile. 
A couple days later, right after his morning bacon, Dwayne's skin broke out in a rash and he could barely breathe. Sheryl packed him into the Porsche and took him to the ER. Somehow the damn tick bite had created an allergy to red meat. For months Dwayne couldn't even look at a burger without getting hives. Of course, Samantha would eat her breakfast bacon with more than usual relish. The little scamp. It took him two full years of increasingly painful allergy injections to get back his taste for beef.

Dwayne's condo in the Gibralter Building gave him privileges at the private dining club near the top floor of the building. The view over the park was outstanding. Above this floor was only the penthouse, a multistory, ten-thousand-dollar-a-square-foot extravaganza space owned by one of Dwayne's richest clients, a Shanghai metals tycoon. Almost all of Western's top new clients were from China. Some serious money was emerging from that former communist state. Across from Dwayne tonight sat Dale Dick, president of FIX News. Dale was glad-handing for his pet project again.

"We gotta ramp up," Dale said. "The Gato Institute newsletter says the national economy is headed south like a fucking goose in the fall. The Institute needs help to keep up their research. We use this for our feature exposés. Now, I'm sure you made bank on Sean's recent death tax exposé. Am I right? Everything you give to Gato helps Sean do his job."

"Why isn't Sean putting the heat on all these damn granges. They're a fucking menace. A perfectly good discount store goes under and the next thing you know they've dug up the parking lot and are raising goats and growing bamboo. You don't know if you're in Hollywood or Hanoi."

"Sean would love to have a crack at them. These things are all over the five boroughs already. I'll bet the Gato Institute has the numbers on 'em, and if they don't, they can get them. With, say..." Dale looked thoughtfully out the window for a beat. “...ten million, we can drag 'em down by their braided armpit hairs. And their boyfriends too... not that they go that way."

"That's the real problem," Dwayne waved his steak knife at Dale. "These folks aren't simple tinkering hippies. And they're not just making bongs in the basement. I've seen some of their software. They have a hidden global marketplace and they only sell to each other. They have their own goddam university. And nobody's talking about it. My own daughter wanted to join. It's that fucking Game they all play. Drives them nuts.” 
"Gamers.” Dale shook his head. "We got very, very low numbers with 'em. Most don't even watch TV."

"Exactly," Dwayne said. "They have no respect for real American culture. Tell you what. I can get you, say five hundred thousand right away for Gato. You keep the heat on these fucking granges and I see some kind of public reaction by..." Dwayne drained his wine glass and set it down. “...April, and I'll write Gato a check for five million more. That's how it works: you give them a donut up front, and promise them heroin later, but only if they deliver the goods first. Donuts and heroin, Dale. It's how you keep 'em honest."

\section{EIGHTEEN}

Years before, Narendra had entered The Zone township of New Tokyo through its enormous, gleaming Akamon gateway, never expecting to exit that way again. Like most of the town's digital residents, he preferred the boundary conditions of the township to the random lawlessness of the surrounding Zone.

The first few years were an absolute free-for-all of violence in The Zone. The careless self-selected to be absent, repeatedly vaporizing themselves and those nearby. Weary of the chaos of the Castalia portal precincts, Zoners made their own towns across the vastness of The Zone's badlands.

New township claims within The Zone required a list with a hundred and fifty names and a site yet unclaimed out on the vast playa. Towns were like anywhere else in The Zone, except they had boundaries with enforceable rules. Townships allowed for The Zone's anarchy experiment to vary according to local tastes. Some towns required no clothing. Others required a minimum purse of GitCoins. Dance bars, gambling joints, and nude avatar sex shows all charged a fee. In Morpork there was magic, both dark and delightful. In Mordor, out on the northern fringe, the magic was only dark. Violence was commonplace in many towns, but it was never organized. The logic of anarchy disallowed gangs, clans, and any orchestrated revenge. 
A wealthy Zoner ponied up for the Sao Do team to program a top predator species, based on a dire wolf, only bigger and faster, hungrier... and zombified. They could only be killed with a head shot. A thousand were distributed across The Zone. Hunters had eliminated about half of them, but not before the wolves eliminated most of the hunters. The towns grew walls against this new threat. Travel between towns, always risky, became even more eventful. Rumor was that someone was looking to fund a species of carnivorous winged dinosaur.

The Zone fulfilled the latent fantasies of Junana members for a dark Stephensonian metaverse. Everyone first entered The Zone from the Castalia Gate. The territory they witnessed was bathed in a constant twilight, with just enough luminance to make out rolling hills of bare rock in the far distance. Far off electrical storms threatened torrents that never arrived. Two-lane blacktop highways diverged across the vastness. The space, being virtual, was expansive; with an experiential size of a large inland county in California or a small European nation. Plenty of room to spread out and stake a claim. Hand-lettered signs at the Gateway junction pronounced the mileage. On the main north road, "New Tokyo: $47 \mathrm{~km}$," and "Mordor, 389km." To the south, "Morpork: $53 \mathrm{~km}$," and "Hogworts: $217 \mathrm{~km}$." The main east road announced "WestWorld: 123 $\mathrm{km}$," and "District 13: $310 \mathrm{~km}$." Dozens of other, more obscure towns had their own signs. Excess speed on the highways was the norm and spectacularly fatal collisions were replayed on internet video channels.

Once the initial work was done on The Zone-and much of that was reused code from Junana-Scratchy O’Hara told the Magisters that all additional coding and maintenance would be billed to the Council in GitCoins by the Sao Do Collective. How the Council would get the anarchist Zoners to pay up was not Scratchy's concern. The Zone's source code was open anyhow, and it was test-driven and as tight as the code for Castalia.

As Scratchy had no desire to do so, the Magisters demanded that the Zoners select someone to be Root on the system. A couple hundred Zoners had the badges to apply. The top eight in the lottery tested in pairs in a virtual ThunderDome. The choice of weapons was chainsaw or samurai sword. The last one to walk out got the job for two years. That person was Priscilla Scintilla, an accomplished sysadmin in her day job in Mountain View. Pris was as fast and lethal as anyone in The Zone. She had killed more avatars with her sword than she could remember. Almost all of them had the bad manners-or were dick-simple enough—to up and challenge her. Her latest weapon 
was a Sharps rifle she took from the loser of a duel. This extended her killing range to more than half a mile.

At the boundary of the New Tokyo township an invisible bubble blocked explosives and all other weapons. The township's towering Edo-period style stone wall kept out the wolves. New Tokyo boasted elaborate pleasure quarters based on kotaku and cosplay culture and couture. The offered pleasures were mainly voyeuristic and soft core, more Tokyo Disneyland than Kabukicho. Karaoke, virtual livehouses, fetish bars, and furry costumes were commonplace.

The denizens of other Zone towns-employing their everyday unkind juvenile mienstarted calling New Tokyo "Assburg," a back-formation from their derogatory name for its inhabitants: Assburgers. Assburgers were mainly meek geeks who wanted to escape their basements without the need to get social in Junana. In New Tokyo, they could network for GitCoin-paid coding jobs without getting shot, wolf slain, or even worse, laughed at.

\section{$\S \S \S$}

When Prasad reported that he needed some extra days to contact the uber-hacker, Dwayne took this as a message to get out of Manhattan in August. He took the jet to London, feeling footloose now that Sheryl was pouting up in Santa Ynez.

Their flat in Kensington Palace Gardens was on the site of a World War Two interrogation center, where rumors of torture made the old house a liability after the war. A new building from the sixties now housed a few flats, each one running more than ten million pounds. It was the perfect address for Dwayne, on a street with enough embassies to have extra police security on each end. Unlike New York, August in London was glorious. Not having to shepherd Sheryl to Harrods meant that Dwayne could leisurely stroll across Hyde Park past the Marble Arch to his favorite restaurant. The park was awash in young couples and families, tourists and locals, basking in the full summer sunlight. Tomorrow morning Dwayne would have a bit of business that didn't need him to be present, but was all the more special for being here. Tomorrow was the final nail in the coffin of The General.

Dwayne's claim to greatness at Western Trust was his role in arranging for financing the dismemberment of General Electronics. The General, as it was called, was the last surviving original company from the founding of the Dow Jones Index. It was a player 
in dozens of sectors, from light bulbs to nuclear reactors, and from locomotives to personal vibrators. The General once employed hundreds of thousands of workers, with hundreds of senior executives and a technology center that had produced more patents than most nations. It was also big and slow in an economy being ruled by the small and quick. A group of savvy insiders approached Western Trust to supply enough capital to take The General private. In exchange they offered a bundle of debt so prime that Buffett would have fainted from its sweet odor. The main problem was the size of the deal, close to a trillion dollars. Lumped in with the prime debt was also about a hundred billion dollars of turd. These were assets so dubious that any valuation of them was purely arbitrary. Seven other Western VPs had turned down doing the General deal, fearing they would alienate their clientele. Dwayne's task was to make a turd sandwich so tasty his clients would fight each other for a bite.

Dwayne's smartest clients snapped up only selected parts of the offered debt, leaving an ever growing pile of turd for the rest. But, with some clever lies and outrageous flattery, Dwayne's dimmer clients took the hook. Transformed into a privately held company, all the former deals with its top management and remaining unions would be up for renegotiation. Divisions would be spun off as new companies and taken public or sold to other private equity firms to be drained of value and then resold. Cheaper suppliers would be found somewhere in Western China for the appliances now produced in Mexico. Bargain prices at big box stores would amp up the sales even as quality went through the floor. Still, it would take years to bleed The General of its assets and the luster from its brand.

Dwayne's original deal management fee went into the billions, but that was just the start. After three years, he opened up a new round of debt for the barely living corpse of The General, secured by its already mortgaged facilities and the ember of its brand, and divided into fresh tranches of solid turd, with the top layer now lipsticked as a platinum investment opportunity. Dwayne sold this new package to those clients with the least amount of oversight, the large state-run retirement funds and greedy internet billionaires looking to capture the additional interest without a thought about the risk. Dwayne made more billions on this second round of deals.

Tomorrow, as the original notes on this second round of debt were starting to come due, the skeleton of The General was to announce bankruptcy, with an eye to reorganization, again as a publicly traded company. The Western Trust was to be given a guiding role in bringing back this once great enterprise. Tomorrow, Western would proclaim that General Electronics was another victim of union greed. They would spin 
off anything that was remotely profitable, and announce an initial stock offering for whatever remained. Tomorrow, the keys to The General's London skyscraper were to be ceremoniously handed over to the head of Western Trust's London office, Benjamin Quinlan IV, the son of Dwayne's freshman roommate.

Dwayne knew the bankruptcy move was a sham, a ploy that enabled fire-sale prices for The General's prime real estate, screwing the current mortgage holders. These mortgages would be sold dirt cheap to Western's selected clients. The buildings would be repackaged as a real estate investment trust, and then remortgaged at their true market value with this new debt resold to the same retirement funds that lost all their money in the previous deal. The General brand would be sold to the Chinese company that now made its washing machines. The chances of The General making it back on the Dow Jones were something less than zero.

\section{$\S \S \S$}

Narendra used his Junana avatar, dressed in black, per instructions. Showing up in WestWorld as a furry koala would be quickly fatal, although probably epic. His ride was waiting outside New Tokyo's Akamon gate, near the hand-weapon checkpoint. The driver sat on his motorcycle, a vintage Vincent V-twin with a sidecar.

"I’m Narendra," Narendra approached him. "I hope I am not late."

"Never too late to arrive in WestWorld." The man wore a brown leather riding jacket and dark brown chaps. Steel-toed cowboy boots and black aviator leather headgear. "Did you bring the deposit?"

"Five-thousand is a bit steep for a few hours work," Narendra said. He handed over the digital chit for the GitCoin fee.

"Five-thousand is what you pay if I get killed on this run. I get killed, I'm banished from The Zone for a year. This will keep me in beer. We make it back here..." The man gestured at the imperial orange glowing gate that loomed nearly overhead. “...I'll keep one thousand. Let's get you dressed."

“Dressed?”

"I'll explain." 
“Honey, you can't wear Game shoes when you're mopping the floor, the disinfectant will eat right through their soles. Next time remember, you need to wear the rubber boots, there are a couple pair of Wellingtons in the closet. And bring a thick pair of socks. Lots of feet been in those boots this past year."

"What do I do with the dirty water?"

"That goes through the sump; that low sink in the mop closet. Try not to spill any on your clothes and wear the goggles. You don't ever want that shit in your eyes. The floor shouldn't take more than half an hour. Do a wet mop first and then a dry mop."

Chelsea nodded wearily. Chris normally did the floors, but he was out sick today. Wheeling the bucket in front of her by the handle of the mop wringer, she started off for the other side of the kitchen and clicked Play.

"Simon here. I'm here in Vietnam, in Hoi An, a beautiful and historical town on the Thu Bon River. Today, I'm doing a three minute interview with Dr. Elizabeth Berteotti.

Most of you know her as "Betsy Almighty..."

“...A name I despise,” Betsy said.

“But a reputation you cannot escape. What should I call you?”

“Desi calls me Liz. I’ll let you do the same," Betsy said. “Until I don't.”

"Liz and I are walking along the riverbank quay. On one side are hundreds of small boats tied up, many being loaded for travel. On the other side is a busy marketplace with everything from flowers to small appliances. It's late afternoon, and people are coming from work to shop before dinner."

"Liz, you and Michael have been here in Vietnam for some time now."

'For various reasons. At first, we were 'at large.' At least Michael was... He's lost a few at-pounds of late. We had to stay out of international airspace. Mike was on a number 
of lists that made travel unwise."

"Surely that's no longer the case."

"Nothing is sure, these days, except insecurity. Anyhow we like it here. Mike is busy running the code for Castalia, and I've got a lot of work to keep me occupied. The river is lovely, don't you think?"

"I can see why you wanted to take this walk."

“We will end up at Ricardo's, Desi's restaurant. It's on the river at the other end of town."

"Where is Desi?"

“I'm afraid he's gone to Japan. He and Ichiro Nomura have some mysterious programming work to finish. And he wanted to see Alice and Itchy's new baby girl."

“Tell me about Shine.”

"Shine. OK. What do you want to know?"

“The Shine system has been around now for some time, and I have to say, it's revolutionary in its own way. How did you come up with the system that connected Shine with jikan and badges? It all makes such perfect sense now, but I'm sure it wasn't easy at the time."

“I'm not taking any credit for jikan. They've been time banking personal services in Japan for half a century. And the badges came out of twenty years of other people's work."

"So tell me about Shine. Shine is the glue that holds everything together. How did this start?"

"The concepts are simple, the math gets quite complex. That's all on a Junana wiki, of course. Jikan is the time you spend and badges are what you know. One is immediate, the other durable. So I figured we needed two types of Shine."

"What brought you to this problem in the first place?"

"I got a call, a summons if you will, from the Council of Magisters in Castalia. A delegation of Sixers had petitioned the Council to authorize a new software utility that 
would show Game level status on their avatars, so they would not have to dress them in Game wear to show off their level."

"I hated carrying around that staff..."

"Sure you did... Anyhow, the first version of this was a simple level marker that hovered like a halo above the avatar when the gamer chose to reveal it. Like so many ideas that germinated in the early years of the Game, the feature pivoted several times, picking up nuance, power, simplicity, and finally its own claim on inevitability.

“The next major revision included an index of users' contributed content on Junana. Every user contribution on Junana is tagged with its contributor: profile updates and original content-photos, music, video, text, images, designs: anything that could be represented digitally-and then meta-content: comments, answers to questions, reviews and curation nodes. Junana is an enormous global cultural bazaar open to use and reuse, to mash-up and remix, to share and critique. All of these cultural transactions create value, a value that would be lost as quickly as a raindrop is in a river unless it was discovered, inspected, reviewed, adored, and most of all, shared.

"The goal was to make a commons for these contributions, and distribute value to all of the actors in these transactions: the authors, critics and reviewers of critics, curators and collectors, and even their teachers. The value was figured as points. Points added up to reputation. Within a year, requests were flooding in to also reveal badges, and the Magisters tried to get in front of this by proposing a master reputation system. That's when things got interesting."

"I remember earning points when these first appeared, not really knowing what they were good for."

"At that time, most social websites offered some kind of reputation hook. These were designed to create 'brand loyalty.' I was looking for something really different: an entire reputation economy."

"And that's where jikan comes in."

"Precisely. Time is the one scarce commodity that everyone has about the same amount of..."

"There are several templates that deal with time and life..." 
"None of which I want to hear about. Not unless you want to call me Dr. Berteotti from now on. I spend far to much time in conversation with Desi, who can't get a paragraph out of his mouth without a template in there somewhere."

"Fair enough. So start with jikan."

"Jikan is the Japanese word for time. Time is the constant. People can pile up properties and titles, but nobody gets more time than their life. I'm not going to go all Stoic on you here, but it does take a lifetime to learn how to live."

"So it's good to start early. Time is precious."

"That better not be template..."

“Just sayin'...”

"There needed to be conversion points between reputation and time, between jikan and Shine. The points you can earn translate into time you can use. The time you spend as a gift or acquiring a skill can become points. A central problem was to avoid the Matthew Effect."

"What's that?"

"The problem of cumulative advantage. The rich get richer and the poor get screwed. To counter this we needed to give the poor more opportunities to gain Shine and the rich more difficulty in holding on to this. That is why all Shine erodes over time. Maybe it's called Shine because you have to keep polishing it to keep it. Look, here we are! This is Ricardo's."

“And I'm only just beginning with my questions. Can we continue this inside?"

"I'll get us a table on the terrace."

"This is Simon, signing off for now. I'll continue my conversation with Betsy Berteotti in my next three minute interview." 


\section{NINETEEN}

Travel in The Zone as a passenger was fascinating for maybe five minutes. Then you realize you have no control and, like car trips with your family as a kid, no real interest in the passing landscape, just an emergent desire to arrive at the destination. Settling back, Narendra opened a browser window on his desktop computer and revisited the Wikipedia article about The Zone.

Some years ago, anarchists who scorned the growing governance efforts at Burning Guy found a place in West Texas that let them dynamite entire mock townscapes, which they constructed for this very purpose over the space of the previous month. If Cthulhu wanted you to simply set shit on fire, they reasoned, he would not have created nitroglycerin. They started an annual event they called KaBoom. Homeland security was not at all keen to have twenty thousand anarchists acquiring advanced demolition knowledge, but hello, this was Texas.

A few of the anarchists were sixers. As was their wont, they found the administrative apparatus of Castalia to be oppressive. They refused to sign up for rooms or times when they could gather, and they loathed the whole Shine and badge social burden.

Mostly they wanted to be left alone to explode things and act badly whenever it suited them. There was nowhere on Junana nor in Castalia where they could cut loose. One of them, and perhaps more, but certainly not a committee of them, proposed that a new zone be created in Castalia. A zone without laws.

The Council of Magisters was divided, but a majority supported the creation of The Zone. It was so named because the anarchists refused to provide a name. Actually, they refused to be required to even decide on a name. The Magisters called on Scratchy O'Hara, who, as the daemon for the software that ran Castalia, would need to oversee the programming for The Zone.

Scratchy was reportedly surprised that the Council was receptive of the idea of The Zone. In a recorded conversation with Simon Bishop, he said, "This speaks well for their understanding of the dynamics of the internet. It is far better to embrace anarchy at a proper distance than to attempt to throttle it, only to find it crawling up your leg. You know, I believe that everyone should have an occasional dose of anarchy, if only to remind them of the benefits of its absence from their daily life." 
Scratchy worked with Ichiro Nomura and a scrum team in Sao Do to build an appropriately themed wasteland, with its own security protocols and user rules; or more precisely, a profound lack of user rules. Once you got inside, all of the usual digital resources you might need to build structures, vehicles, and social scenes were available, as well as a broad range of devices for their demolition. Custom vehicles and weapons were soon available for sale. A GitCoin shopping gateway was programmed so that members could pay each other for their services and game wear. Although virtual weapons were plentiful, the space was not designed as an organized war game. It did have its own user login and ran on its own mesh servers, completely independent from Castalia or Junana.

Narendra opened YouTube, searched for "WestWorld Zone" and clicked on the top link: a video titled "Howdy Kitty: A warning from Michael O'Hara." The view opened on the main street of WestWorld, a Hollywood backlotesque $19^{\text {th }}$ Century American Wild West townscape. Then the voiceover narration started. "This is a lesson to all you assclowns who keep shooting at me in The Zone. Just take a long look and remember what you see."

The video showed a user log in. He appeared on the street. His avatar was naked, apart from an adult diaper, leaking badly, a bright pink Hello Kitty tattoo on his chest, and, clearly unbeknownst to him, a barn-red and stark-white paper target duct taped onto his bare back, freshly painted, dripping red rivulets into his exposed butt crack. The words, "Shoot me, Please" were scrawled in black across the massive white and mottled brown expanse of the ass end of his diaper. He turned about in his confusion and managed to look down and whisper, "What the fu..." before the first bullet caught him between the shoulder blades, exiting with a gush of blood between Kitty's eyes. Half a dozen other bullets struck him as his avatar fell twitching into the dust. The video played this action again, and then again in slow motion. The camera point of view then shifted into selfie mode and the familiar face of Scratchy O'Hara's avatar appeared.

"Next time you see me in The Zone, just leave me be. I'm tired of your cowboy bullshit." Narendra read the description and some comments to the video, which already had several million views. As daemon on the system, Scratchy gave himself immortality. Someone had to test the UX without getting killed every ten minutes. As he could not be slain, Scratchy figured it was not his place to kill anyone else. So he went unarmed. 
Certain individuals took to shooting Scratchy on sight, simply to watch his avatar tumble backwards, spout blood from the wound, and then pick itself up again. At the end of his patience, Scratchy programmed this response. Anybody who shot him or blew him up from then on got the "Howdy Kitty" treatment.

Narendra had not heard a single wolf on the two-hour run from New Tokyo. At the start of the trip they rode carefully across the flat white playa that made up most of The Zone. They hit the two-lane blacktop that connected WestWorld to the Castalia Gate and the driver pushed the Vincent to its top speed of $120 \mathrm{mph}$, slowing slightly to pass a couple of armed convoys, or when the roadway surface had been warped by explosives and poorly repaired. Anarchy was the rule in The Zone. Most anarchists would agree, although not when in a group, that anarchists were shitty at road maintenance or at any service that required a lot of volunteer effort.

Unlike New Tokyo, WestWorld had no gate, no formal entrance at all, just a scattered collection of shattered vehicles that had been pushed off the roadway into increasingly tall piles. By the time the Vincent made a final shallow turn onto the main street, under a wooden sign that read "WestWorld" in runny red paint and with a garland of wolf heads dangling from ropes, the debris was nearly a tunnel. Then the blacktop gave way to dirt and the simulated street became a frontier townscape, with wooden sidewalks, hitching posts, and board-and-baton fronted, two-story buildings with signs advertising weapons storage or sex for sale. Their porches sported oil lamps. On the corners, iron barrels contained wood fires that added some light, and belched black smoke. Like the rest of The Zone, WestWorld never saw full sunlight.

Narendra's driver glanced left and right, prepared to swerve to avoid any sudden danger. The street was empty of vehicles apart from a couple of wrecked $4 \times 4$ s that looked like they had recently been the center of a gun battle, one of them still smoked from a spray of bullet holes in its hood. Narendra listened for gunfire. All he could hear above the deep throttling rumble of the Vincent's 1000cc twin engine was honky-tonk piano and animated voices.

The driver had explained that most of the towns, even the rough and tumble ones, had settled into a quieter phase. Years of rampant violence had eliminated those who most enjoyed this. While TZ towns had no rules (apart from boundary conditions) nor laws, they did develop local customs, a kind of memory device that permitted them to disabuse those who were overly random in their personal violence. Willful murder was a matter between the killer and the corpse, but collateral damage was a community concern. The penalty for accidental homicide was usually permanent banishment from 
the town. Offenders who showed their face again had a half-life under an hour. Still, there were plenty of other towns in The Zone, if the wolves didn't get you first.

While there were no socially determined laws in The Zone, this program had some features personally added by Scratchy O’Hara. The first was a user entry condition. You could always enter at the Castalia Gate. Otherwise you were automatically logged in exactly where you logged out or were killed. If you logged out during a bloody bar fight and did not wish to risk the road trip from the Gate, you would need to log in at the same spot. You had to hope the survivors from the melee were not waiting for you.

The second feature was that logging out included a full minute timer and a visual clue, a red halo over your head. This meant that you could not simply log out in the middle of a firefight without attracting some attention. As a third feature, every weapon you carried could also be seen as a glowing icon above your head. You were free to pack as much heat as your could carry, but not to conceal this fact.

Killing someone's avatar anywhere in The Zone had serious, although not physical, repercussions for the victim. Those killed were banished from The Zone for three days, in the first instance, three months the next time, and a full year for every time after that. The dead were not banished from Junana or the Game, and they were usually pissed off. Killing someone in The Zone was a fairly straightforward way of announcing you were their enemy. You might not want to see them at the local bar that evening.

Accidental death had the same rules, and the physics engine in The Zone was state-ofthe-science. High explosives behaved realistically. This meant you had best be far enough away and behind something seriously massive before you set off that bundle of dynamite at the door of the virtual jail. Noobs who tried tossing a hundred gram slab of C4 with an eight second fuse discovered that they could not throw and run fast enough to exit the blast radius.

The driver pulled up in front of a wooden building, mostly identical to the ones on either side, except for a sign: a painted image of a young woman's curvaceous leg, severed at the top of the thigh, the wound leaking blood in a crimson painted rivulet. The leg still wore a black fish-net stocking and an emerald green stiletto-heeled pump.

"Ruby's Leg," the driver nodded at Narendra. "I'll be here for ten minutes, max." He held up ten fingers. "If you're not back here in that time, well then you're on your own. Remember the instructions I gave you. Do not push the button unless you are about to die." 


\section{$\S \S \S$}

After the lunch rush, Chelsea went to collect the trays the students had left in the rolling racks next to the wall of the kitchen. They were usually pretty good about cleaning their plates before they stacked them. Chelsea liked this opportunity to get out of the kitchen even just for a few minutes, and took her time walking the filled racks back to her dishwashing station. She had her earbuds in, so nobody talked to her.

"Simon here. I'm talking again with Betsy Berteotti in Hoi An. We are on a patio eating lunch at Ricardo's, a Cuban restaurant. I'm holding this ear of corn that's been covered with some kind of crunchy, cheesy, spicy crust and then barbecued. It's possibly the best thing I've ever eaten."

"This is just the appetizer, Simon."

"Liz, in three minutes, please tell me about SunShine and StarShine."

"Let me start with the connection between Shine and jikan. Shine is its own economy, but we needed to have Shine points be convertible to jikan. At some point your reputation has to serve your life needs."

"Absolutely," Simon said. "People spend time, they spend valuable jikan, to build their Shine."

“How do you get Shine to work for you?" Betsy said. "Step one was to make StarShine into a jikan amplifier. The more Starshine points you have the more jikan you wake up with each day. Jikan to pay for things like a bed, food, or transportation. Right now, each StarShine point gives you four seconds of jikan each morning. Fifteen points for a minute of jikan you've saved each day. A person with enough Starshine could livecould be comfortably housed, clothed, and fed-on the extra jikan she receives just from StarShine."

"Who gets to decide how many points there are?"

"The point system has been negotiated through the Council of Magisters, who gave Meisters a great deal of Shine points, and Grand Meisters an obscene amount..."

"I'm looking forward to being really lazy when I'm old." 
“They say you clean toilets everywhere you go.”

"It's something I've gotten good at."

"We've had dozens of grange travelers come through Sao Do recently. Guess what? They all want to clean toilets too."

"A clean toilet is a happy toilet..."

"Here's the kicker. People living in Sao Do are also cleaning toilets, like all the time. Just to say they do that."

"You're blaming me for having a clean commode?"

"I'm saying that if you had offered to bake croissants, we'd all be eating better breakfasts instead of polishing porcelain. Now, where was I?"

"Starshine."

“We didn't want to create a class of people who had enough Shine to sit on their asses all day and have other people do their work. I guess, except for Grand Meisters."

"It's an occupational hazard."

"Which brings me to step two. We made Shine really hard to keep. Apart from Game Shine, all other Starshine point sources, including badge levels, require regular jikan. This means that a Master badge holder who wakes up with enough shine to eat and sleep that day still has to work using her badge in order to keep her Shine points. The Council sets the level of skill-sharing required to keep StarShine from eroding."

“Use it or lose it. How about SunShine?"

“Now, SunShine is very simple. It's a measure of gratitude of those you have served through your gifts; a currency you can exchange by offering yourself to your community. The teacher expresses her gratitude for the attention and focus of their students. The students express their gratitude for the opportunity to learn. The babysitter remarks on the qualities of the home, and the parents note their thanks for the care their children received. As there is no cash involved, the real currency is gratitude. The sharing economy is wrapped in a reputation ecosystem."

"If you're expecting gratitude, is it really a gift?" Simon said. 
"We've discovered that those who are looking for gratitude are the one's that get the least. There's some kind of zen sensibility going on here."

“People are attuned to authenticity. You're saying the system hooks into this?”

"Somehow Shine feeds authentic gifting and gratitude. There's some small-scale trolling, which is generally self limiting. Our goal is to build a public record of social reputation-of Shine-and create a currency that competes fully with cash and monetized credit."

"A reputation you can bank on, and live off. Wow."

"Again, the mathematics behind this exchange are really fascinating, a lot of really well figured sorting algorithms and set theories. We enabled a conversion between the level of SunShine you acquire in a year and your personal StarShine. So you can accumulate durable reputation out of the stream of recognition you get from others."

“That's elegant."

"It's really fucking elegant, Simon. I'm particularly proud to have helped this become a useful tool in the world. I'm also glad I'm not in charge of administering Shine."

"I understand the Magister's Council have taken this on."

"In their typical fashion. The Magisters created the Shiner Synod, selected by lottery from a cohort of Sixers and Meisters who are also required to have master-level badges in statistics, social psychology, and economics. They are responsible for governing the emerging global reputation economy as a commons. I check in with them every couple weeks when they have questions about the algorithms. They run the master models on the Castalia mesh, but I have a clone here on my supercomputer."

"I've heard that Shiners have taken to having their avatars wear fez hats and ride around Castalia in miniature Ford Mustang cars shouting, "Whuffie for all, and all for whuffie!"

"Would not surprise me in the least. They are a spunky bunch. Ah, here come the plantains. You will like these!"

"Thanks Liz. This is Simon again. Signing off from Hoi An."

\section{$\S \S \S$}


Narendra stepped through the swinging doors of Ruby's Leg Saloon. At the sound of their creaky hinges the piano player game piece looked up and the music stopped. Narendra's avatar's left hand was in the pocket of the black peacoat the driver had supplied. His fingers gripped the switch. His right hand fingered the digital chit for delivering his message. He was using haptic gloves to signal his grip on the button and the chit, and voice commands to move his avatar. He could almost feel the button under his thumb.

The room was expansive, with an elaborate carved wooden bar across the far wall and dozens of round tables scattered around the floor. A balcony ran across three of the walls, with steep staircases left and right. There were several dozen avatars in the room, clustered into conversations. Black was the fashion. Most of them appeared to be heavily armed. A forest of icons gleamed above their heads; mainly unnecessary, as their weapons were worn ornamentally: pistols, knives, sticks of dynamite, and leather bandoliers of shining brass bullets. Torsos and arms were heavily tattooed. A few of them looked over at him and then back to their mates. The piano started up.

As instructed, Narendra made directly for the bar. The floor was unpainted wood, covered in swirls of sawdust and darkly stained in several spots. The bar was backed by a huge mirror and an array of liquor bottles. Narendra's mission was to deliver the message and get the fuck out of Dodge. The bartender was elderly, dressed in a white dress shirt, red bow tie, and suspenders. His white hair was oiled with a center part. A standard game piece for a joint like this.

While the bartender helped another customer, Narendra found an empty spot near one end of the bar. He glanced back around the room. He had imagined that Ruby's Leg would be more lively, with a floor show and keno games, loose women, gigolo dandies, and tough hombres playing stud poker. While some of the whispered conversations around him might be planning major cyber-criminal capers, nobody seemed to be having a good time. It looked like the party had already ended, and these were the ones who didn't get lucky. Not much of a lulzone. He voiced over to Shine View mode. As expected, most of these avatars showed little shine, and few badges. But across the room in the shadow of the balcony one avatar blazed like a nova. More shine than Narendra had ever encountered.

"What's your poison?" The voice startled Narendra and he almost pushed the button. He turned to the barkeep. 
"I'd like to buy a round for the house," Narendra said. He held up the digital message chit.

"That's mighty kind, stranger." The bartender reached out and took it. When he did this every person in the room got a message they could read if they chose. The message appeared as a glowing shot glass within reach. Picking this up displayed some text and deposited a hundred GitCoins in the viewer's account. The text was short: "Looking for help with an attack on a very well protected, Sao Do authored website. Top pay for delicate work.” There was a phone number to a disposable cellphone Narendra had purchased.

"I think I'll be going now." Narendra started back toward the door.

At a table in the corner, back in the shadow of the balcony Priscilla Scintilla whispered to her companion. "This will get ugly, believe me."

\section{$\S \S \S$}

Break time, Chelsea found a spot outside, an old picnic table that had been pushed to the edge of the lawn away from where the students hung out. She liked to lie down on the table and watch the clouds, not daring to close her eyes. In her third week on the job, Sally had come looking for Chelsea and found her fast asleep on the table. The night before, Chelsea had volunteered to take tickets at the performance of The Importance of Being Earnest her gumi's repertory theater club had put on at a playhouse downtown.

The Rabbit Gumi celebrated births and weddings, commiserated divorces and deaths. Chelsea had recently gone to her first funeral. Dwayne didn't believe in death. Since he had already escaped taxes, he figured he might as well try for two. The family had a concierge medical service. A brace of doctors would drive up from Brentwood in LA to their house on Hope Ranch for their annual checkups. The Asheville grange's medical plan was not quite that friendly, but it tried. Chelsea could schedule her checkup at the small clinic in the grange. Not that she had anything to check up. Between the ultimate team practices, walking everywhere she went, and the wholesome food she got on her job, Chelsea was in better shape than any time in Santa Barbara. Chelsea lay back on the table, a brisk wind played at her hair. She pushed Play. 
"This is Simon, in Kyoto, Japan, talking with Alice Nomura, a member of the original Posse, and now the manager of the WT store here on Kawaramachi Street. Alice, I appreciate your time. What a great looking store!"

"Simon, it's my pleasure, anyhow we have a surprise for you later."

“Great! Tell me about the start of the WT chain.”

"The first WT shop was in Shibuyaku, Tokyo. Like this store it has cement floors, burnished steel walls, and recycled wood ceilings."

“Looks like a MUJI store.”

“MUJI, IDÉE, Apple, and a hint of DWR: the store is designed to feel upscale. WT only sells WholeTale merchandise with a rating of 70 and above. Every object is Creative Commons licensed to be copied, and comes with full instructions to do so."

“Every object has instructions on how to make more?”

"Materials lists, patterns, computer design specs, everything. And also the Junana contact information for all the makers who crafted the object you're buying, in case you had any questions."

"Consumption has gotten really complicated," Simon said. "I remember walking into a shopping mall with my debit card and buying whatever caught my attention. Now I feel like I need to take a class."

"We've always needed to know, even before we realized, but we lacked the means to do so," Alice said. "Having the information changes the entire ethical ground of our decisions. Spimes expose their whole lifecycle. Not only do we know what misery was caused to fashion an object, we also know the price of its disposal.

"So now we are implicated in the misery of what we consume?"

"It's not all just a guilt trip. The other side is this: now we can support people across the planet who are working to build misery-free goods for our commons. The next step is to value the design and materials of the objects we use. That's the goal of WT stores.

Simon said, "General stores sell consumables, staple foods, household cleansers, everyday items, essential hardware, and other necessities. All of these are well designed." 
"Yes, and they're selected also to be as economical as possible while still being WholeTale. In the WT store we take away that filter. We sell home and fashion objects of really high value at equally high prices for the rest of the world. We use these funds to support seeding the same designs and materials inside the global grange commons, at cost.

"Show me..."

"Here's a book stop. This is sand-cast, up-cycled aluminum, burnished to a mirror surface. Made in Germany. Hold it."

"It's really heavy. And freaking elegant. How much is it?"

“Twenty-thousand yen. That's something around two hundred dollars. You can get a simple, hand crafted bent steel book stop at a general store for maybe five dollars."

"You can get a set of those at Halmart for a buck... hey, what did I say? Everyone is looking at me like I just beheaded a puppy."

"We don't talk much about Halmart," Alice said. "It's destroyed a lot of local merchants in the past couple decades."

“What's your job here, I mean what are your roles?"

“I have several roles. I manage this store, it's the seventh WT store on the planet." "How many are there in total?"

"Including airports, about three hundred so far, with plans for many more. I'm also a buyer for the chain. When I find an object I like, I can suggest that we carry this in our stores and online. This brings me to our surprise. Follow me."

"Alice is leading me to the rear of the shop. All of the sales team is lined up in front of a display of brushes. What is this?"

“Here, Grand Meister.”

"She has handed me a brush, about a foot long made entirely of some kind of dark brown fiber, collected into a tight bundle and held together with copper wire."

"This shuro boki brush is made by former apprentices of Saitou-san, whose family's shop was just around the corner on Sanjo. It's a new model, with some design 
improvements. This is the finest toilet brush on the planet. If you approve, we would like to call it, "The Bishop'."

“'The Bishop.' That's... well I am honored. Sure, go ahead.”

“We all thank you.” Applause rippled and stopped.

“Arigato, arigato. I’m sorry, I can't stop laughing. It's a beautiful brush...”

"You can keep that one, Simon. But the next one will cost you thirteen thousand yen."

"Alice, it has been a pleasure. This is Simon, signing off from Kyoto."

\section{$\S \S \S$}

Narendra had taken a couple steps when a giant hand grabbed his shoulder from behind. His avatar was spun around to face an avatar almost twice his size.

"And who the fuck are you to waltz in here..." The face scowled under an unruly mane of black hair. A large cigar was clamped between a set of teeth that were mostly metal. The hand had returned to the butt of a larger silver revolver in a leather holster strapped to a sumo-sized waist.

"I am only leaving just now," Narendra tried to find the key sequence to back away.

"You won't make the door."

"Cool it, Tiny," a female voice said from his right. She moved in cat-like steps from her table in the shadows and stood between them.

"This Assburg dweeb thinks he can walk in here and offer cash to take down a Sao Do website..." Tuong "Tiny" Nguyen said.

“Obviously he doesn't know better,” Pris said.

“Then it's time I give him a little lesson."

She turned to face Narendra.

“Dr. Prasad, you have offended my friend Tuong here....”

"You know who I am?" Narendra said. Laughter erupted around the room. 
“Tiny wants to shoot you. I should really let him. What do you have to say for yourself?” Narendra pulled his avatar's left hand out of the pea coat's pocket. What he held up looked like an old Nintendo joystick controller hand grip with a big red button on the top. Wires from the bottom joined this to something inside his coat. Narendra's avatar's thumb hovered over the button.

Everyone near him took an immediate step back.

"Dude's got six sticks of TNT and four hundred grams of plastique," Pris said, eyeing the weapon inventory above his head. This one had been so frightened looking nobody had seriously bothered to check out his weaponry.

Around the room, halos popped up: people were logging out. Those nearest the doors began to sidle toward them.

"I need you to just focus on me for a minute." Pris held up her hands in the familiar Junana greeting. She made eye contact with Narendra's avatar and smiled.

"Your face was scanned a mile out. OK? You are Narendra Prasad, M.I.T. PhD. You work at Western Trust. If our face-recognition software could not discover who you were, you would never have made it into WestWorld alive. I heard you talk at DefCon a couple years back. I have to say I'm disappointed in you..."

“This wannabe Cholo doesn't have the stones to push the button. Why don't I shoot him in the head," said Nguyen. His avatar pulled a Colt peacemaker from its leather holster on his hip.

Narendra mashed his thumb down on the button.

"Shit!" Pris exhaled. There was a significant pause, and then the room took an inbreath.

“Dweeb doesn't even know how to wire...” Nguyen said.

“I just armed it,” Narendra said. “Me, I can always do something else for three days.”

“Three days! He's still a Jesus, and he's got a dead-man trigger on his device," Pris said to the room. "Everybody calm the fuck down! And that goes double for you, Narendra."

“This is your fault, Pris. I told you we should never let a Jesus into town.” 
"Not now, Tiny! Dr. Prasad is the one in charge." Those who had died a couple times in The Zone felt an understandable envy for the ones who could die and come back in only three days. Seemed like an unfair advantage.

"All I want to do is leave," Narendra pleaded.

"And leave you must. The door is over there." Pris gestured. She stepped back and in a clean single motion she held a samurai sword raised above her head. "Everybody give Dr. Prasad here all the room he wants. Anybody makes a stupid move, they will answer to Priscilla Scintilla this time next year."

His left hand held out, thumb mashed resolutely on the red button, Narendra walked directly toward the swinging doors.

"Prasad." She spoke to his back. "I catch you again anywhere in the zone, I will gut you like a carp."

Out on the street, the driver had turned the bike around and was leaning against the seat.

“Fuck!" He looked at Narendra's outstretched hand. "You armed the damn bomb."

“Get me out of here!” Narendra's avatar climbed into the sidecar. "If you try to leave me I will explode it."

"Keep your thumb on that button! We get out on the road, I can disarm it." The driver watched him climb into the sidecar. He started up the Vincent and accelerated out toward the highway. Narendra looked back. Nobody was following them, or even watching them. It was just another day in WestWorld.

\section{$\S \S \S$}

The campus cafeteria was a good mile and a half from her gumi house, and two miles from the grange, but the walk after work was pleasant enough; tree shaded sidewalks and kids playing in the yards after school. Chelsea had started to join the early evening crowd in the grange's public bath. She would scrub off the cafeteria grease and then slip into the great hot tub. The conversations in the bath were casual, chatter about happenings on the weekend and such. Sometimes another Rat dachi buddy would show up. Chelsea set off from campus and clicked Play. 
"Simon here, with another three minute interview. I'm still in Sao Do talking with Michael 'Scratchy' O'Hara. Scratchy, you are in the middle of what's next in the Game. Tell me, what gets you excited about tomorrow?"

"I've been on the phone with Ichiro and Desi, who are in Japan with Doc Seals from MIT, Jack and Winston are calling in from Philadelphia. They've been talking about flipping the economy, so we are going to build services into Castalia to do just that."

“Flipping the economy?"

"Up until today, companies made products that they hope people would buy. Sometimes that works, often it doesn't. Sure, companies do market research, but every new product is a gamble. It's like parents picking out their kid's Christmas presents without asking them first. When I was a kid, I knew exactly what I wanted for Christmas. I didn't always get it, but there was no lack of information from my side. My main problem was that the stuff I really wanted hadn't been made yet. I wanted to build robots that could fight other kids' robots. You following me?"

“Robots. Sure."

"Nobody was selling robot kits, so I got Tinker Toys and Lincoln Logs and crap like that. Where was I?"

"Flipping the economy."

"Right. We now have several thousand granges across the planet. That's millions of people who need pencils and chairs and new shirts and whatever. What if they could make out their lists of stuff they wanted and have producers bid on these?"

"Then they would be a consumer coop..."

"More than that, they would be a world-wide network of consumer coops. And their list could specify new designs, new materials, new requirements for the goods they would buy. Shirts made from fully organic cotton, woven and tailored by workers who are well paid. Chairs made from one-hundred percent renewable wood, and built from open designs by fellow makers. Maybe they want to create a prize for the best new chair design, and then order ten thousand chairs. When granges pool their funds and their dreams, they can demand that producers build what they will buy. The producers get real orders for products without needing to guess what their customers want, and 
without paying marketing firms to tell them what consumers want. And without advertising firms telling consumers what they really want. So, no more marketing and advertising expenses."

“They'd still need a place to negotiate all of this..."

“That's why Itchy and I are on this like flies on kitten turds. He's designing a new building for the edge of Castalia, not far from the CraftHalls, a space that would support this new economy, which Winston calls "demand and supply."

"Demand and supply. I get it. Flipping the economy. These new products, won't they be more expensive with all those new requirements?"

"And more durable, and better designed. Doc figures the savings from advertising costs and unsold inventory will make this new Game B economy far less expensive overall for everyone, even as the quality of the products improves. Everything that gets manufactured is already paid for."

"But what about individual choice? What if I want a shirt that's different from what my grange has ordered up?"

"Once the system is running, any individual member can go to the open design catalog and order a bespoke object. You can always get your favorite hemp jeans made in the color of your choosing. You can even upload your own designs. Plenty of makers and crafters around to serve these needs. And you can learn to sew. I would think a Grand Meister should know how to make his own fucking shirt."

"When does this all happen?"

"I've got my Castalia crew working on the commerce engine and the database designs as we speak, and Itchy's got a team designing the new building. I'd say we will be in beta in three months. Which means I'm really busy..."

"I can see that."

"Don't you have a toilet to clean somewhere?"

“OK, right. Time's up. Before I go, tell me, what's your formula for a full, rich life?”

"Shit, you mean I'm old enough now to field this kind of question? Well, grasshopper, here it goes. Find a woman who is a lot smarter than you are, and then each morning discover some way to convince her, against her better judgement, not to leave. Now, in 
your case, seeing as you are a Grand Meister in the Game, this advice might not be of much service."

"Thanks, Scratchy. This is Simon signing off from Sao Do."

\section{$\S \S \S$}

Pris sprinted up the stairs to the balcony and then another set and out on the roof of the saloon. She was carrying the Sharps. Nguyen could be a real dick but this time he was right. Noobs should not be able to pull this kind of shit in WestWorld. She moved to the front of the building, with a view out on the road. As soon as the bike was clear of the debris piles she would have a shot, but only for a second. She shouldered the Sharps. The bike's trajectory angled directly away, so she would be leading it for distance. The bullet would fall a meter or more before it struck. She could hear the Vincent's engine revving as the bike hit the main blacktop. She had preset the vernier sight for just such a shot.

The Vincent streaked out from the main debris field. Its driver twisted the throttle wide open. He glanced nervously at his passenger, who was holding the switch with one hand, and hanging onto the sidecar's handle with the other. He glanced in his rearview mirror, but nobody was following. He could have sworn he spied a flash of light.

Narendra was just settling into the routine of the motion of the bike when he saw the driver's head vanish in a sudden gush of blood and gore. As the headless body slumped backwards off the bike he heard a faint, sharp report of a rifle shot and the bike shuddered and skidded before the engine stalled. The engine's drag on the back wheel kept the bike from tipping over. Instead it careened to a stop not far from the roadway. Only then it occurred to Narendra that the driver had been shot. Narendra sat in the sidecar for a whole minute, assuming he was next. Then he got out and stood a little ways off. He looked about for a tree or a rock, but the blacktop cut through playa flat as a DVD. There was nowhere to go but back into WestWorld or onward into The Zone. Somehow he was still holding on to the trigger. In fact, his hand seemed to be locked into some kind of rigor inside the haptic glove.

If he had a day, Narendra might be able to figure out how to work the Vincent. Unfortunately, the clutch was on the left hand side and his left hand was occupied. 
Likewise he had no time to learn how to disarm the device. He could just log out and enter from Castalia again, or he would need to find someone headed toward New Tokyo, convince them to give him a ride and then attempt to walk through the Akamon Gate. His belief was that the explosives would just disappear as he passed through the town's membrane.

Pris watched the stunned avatar stumble away. Amazingly, the bike was not damaged. It was a fair prize. She doubted Prasad would last long out in The Zone. She considered reloading the Sharps. Then she saw them.

Narendra sat back in his chair. He realized he was soaked in sweat and seriously needed to pee. He had set his avatar walking down the road. Now he moused over to log out. He would need to pony up once again for an escort from the Castalia Gate to New Tokyo.

Just before he saw them he heard them. Zombie wolves. Three of them. They ranged across the playa from a short hillock off to his right, maybe five hundred yards away, racing in a tight phalanx, each one bigger than he had imagined. Beautiful in their motion. Horrible in their intent. Headed directly for him.

The idea of running from them seemed absurd. Might as well flee a bullet. After an instant mental calculation Narendra knew he didn't have sixty seconds to wait. He might have half that. All he had was the device, but that would be enough. When the first one hit, the dead man trigger would earn its name.

Pris watched the wolves approach, marveling at their grace. At the very last instant, the lead wolf accelerated. Its massive head strained forward, jaws agape, as it leapt at Prasad's head. The blast took all three wolves and Narendra in a sudden pink cloud of dust and vaporized digital flesh, followed directly by an explosion of the nearby Vincent's fuel tank. A brief ball of fire lit up the scene. "Well, shit," she said.

Narendra watched the standard third person slow-motion replay of his avatar's death. The good news was that he could get back into the Zone in three days. The bad news, he realized suddenly, was that he no longer had to pee. "Well, shit," he said.

Pris made her way back to the now-emptied bar. Most of the avatars had logged out, others had fled. Nguyen was still at the bar. She nodded over to him. He grinned. They had all heard the blast. She went back to her table. He was still there.

"Pretty fancy shooting there, missy," Scratchy O’Hara said. 
"I was aiming for the dweeb." Pris sat and leaned her chair back against the wall. She raised one finger. "What's the top nerd from an international asset management company doing here?"

The bartender appeared. He set a shot glass brimming amber fluid carefully on the table and retreated. Pris snatched this up and quaffed it down in one gulp.

"Half the folks in Ruby's leg work at Sao Do," Scratchy said.

"I guess he didn't know that."

\section{$\S \S \S$}

Narendra, freshly showered and dressed, returned to his computer chair, which gave off the tang of the pine-oil cleanser he had used on it. In the shower he had realized how absolutely screwed he was. All of his secrecy precautions had been casually shattered. If he succeeded in helping to hack Castalia, his digital life would be made an inferno of retribution from the world's best griefers. If he failed, that rat bastard Mooney would fire his ass.

His disposable cellphone vibrated on the desk. He read the text message: "Know exactly who you need for delicate work. Meet me at the Firing Pin tonight, ten sharp."

He had heard of the Firing Pin, a grunge bar in a rundown warehouse district in the Bronx, a site of regular violence and occasional mayhem, and a meeting point for Zoners looking for information on the whereabouts of that night's dance rage.

"Perfect," he said to the room. Could it get any worse? He texted back. "Roger that."

Once The Zone was in place, it was only a short wait before Zoners created their own granges. These ran on an economy based on GitCoins instead of Shine and jikan. Along with occasional explosions, their late night parties made keeping a low profile in their neighborhoods difficult. These ad hoc grange spaces became known as "grunges."

Grunges attempted to realize anarchy as a social norm in real life. Society in a grunge allowed only personal friends, personal enemies, and strangers. There was work for hire and skills to acquire. Gangs were not allowed by custom. Fistfights were not uncommon, with the losers moving on or skilling up. Losers IRL also tended to load up their virtual Glocks in The Zone. For some, it was perfect, but it also supported a 
dynamic social tension that appealed to certain personality types that did not always play well with others.

Zoners often hosted parties called "rages"-another source of GitCoins. The locations for the rages were publicly unannounced. Zoners would rent or simply occupy abandoned factories and warehouses. The larger rages were video-streamed to virtual pay-to-party scenes in The Zone.

\section{$\S \S \S$}

At ten o'clock the Firing Pin was just starting to get lively. The building was a hundredfoot square, two-story shell, with rows of metal factory windows on the front and back and exposed brick walls on both sides, where bars ran the width of the room. A small kitchen had been constructed on the back wall, flanked by fetid restrooms. Some round tables had been pushed to the edges of the space. The main floor was filling up. The bars were jammed. At some point in the evening bluetooth beacons on the walls would send a coded message to all cell phones within range announcing the code for the remote hidden location of the all-night rage. Over the next hour the crowd would slip away, having found their friends and made their connections. Most would already be blazing.

The sound system and the syncopated lighting assaulted Narendra as he stepped inside, past a couple of bouncers the size of Buicks. He sent a short prayer to Ganesha for his contact to be punctual. The Firing Pin was an order of magnitude more threatening than Ruby's Leg, partly because all the weapons were concealed. The tattoos were not, and some of them would make a Russian criminal blush. The potential damage of any wrong encounter here would be immediate and corporal. Narendra stepped cautiously into the crowd. He pulled out his phone to check for messages. A female voice behind his ear caught his attention.

“Delicate work doesn't come cheap, Dr. Prasad."

He turned. She was slight, mid-twenties, a shock of electric blue hair, a pair of bluer eyes. She seemed not so much dressed as wrapped in layers of translucent black stretch webbing, as though she had barely escaped an enormous demonic spider.

“Do you have the name for me?” he asked.

"Names don't come cheap either, I'm afraid." 
"How much?"

She took him by his arm, and turned toward the door. "Outside is better," she said. He was keenly aware of her pressing his arm against the side of her breast. They strode out between the body guards, who stood like the giant menacing guardian figures at the gate of the Temple of Ecstasy in New Tokyo.

Half a block away she relaxed and let go of his arm. They kept on walking. Two blocks ahead was the subway. He figured their business would be done before they arrived.

"Ten thousand dollars for a name that you never heard from me," she said. "He's the only one I know-maybe the only one on the planet-who you could be sure can do this kind of work."

"I didn't bring cash. I can transfer money into an account or add it to a cash card from my phone. And I'll need more than just a name. I need a definite contact for this person."

"Works for me," she said. "One thing. I'm saying he's the one person who can do it, I'm not saying that he will choose to. You'll have to meet him in The Zone."

“Not in WestWorld, please," Narendra said. "They don't like me there.”

She laughed. "No, he's way too notorious to show his face in WestWorld. He's in the only township in The Zone where he won't get shot on sight."

"A town worse than WestWorld?" Narendra was certain he really didn't want to know. "He's in New Tokyo. All the most infamous hackers and griefers hang out there, once they've been shot or blown up enough times in the rest of The Zone. Assburg's not all furries and princesses."

“Everywhere I go it is.”

“Why, of course. Let me guess.... Panda? No. Tanuki?”

“Koala," he said.

She failed to suppress her laughter.

"You have a name to give me?"

"Nguyen," she said. 
“Not him!”

She held up a hand. "You met 'Tiny' Nguyen at the Leg. This is his older brother Nam. Tiny likes to act up in The Zone, but they say he's a gentle geek in the meat. Nam's a genuine badass. Their father, Phong Nguyen, was one of the original fifty programmers that Grand Meister Desi assembled in Sao Do to code the Game version 1.0.”

"Quite the family."

"Phong's a hard act to follow. Nam was a bad fit for Sao Do. He could never outshine his dad, so he looked outside the box for some ways to make good in the marketplace. You remember that huge airline ticket hacking scandal a few years ago?”

“Millions in bogus flight reservations?”

"That was Nam." She nodded. "Sao Do had done the programming for the airlines, and so he made them look bad. They kicked his ass out of Sao Do, which is why Nam lives down in Ho Chi Minh City. Any time any Sao Do programmer sees Nam in The Zone, he has a license to kill on sight. New Tokyo is the only place Nam can hang out, I guess, at least until someone invents a fatal digital lap dance."

“New Tokyo is a big place. How do I find him?”

"I can give you precise instructions. First, you need to add ten thousand dollars to this card." She held up a cash card.

Narendra went to the banking app on his phone and made the transaction with her card. He handed it back. She looked at the balance.

"Fine and dandy. Nam hangs out at a hidden griefer bar in an alleyway off the left-hand side street of the Temple of Ecstasy." She pulled a name card from the delicious shadows of her web-shrouded cleavage. "Scan the code on this card and your avatar will have the entry password."

The front of the card said simply "Magick Theatre." The back had the code symbol.

"This is my station." She gestured toward the subway entrance just ahead. "Remember you didn't get the card from me. In fact we've never met. I do hope you are really good at your job."

"What?" 
She called out as she started down the stairs. "Because, you pull some lame stunt with Nam Nguyen and every Sao Do nerd will be looking to take down your servers."

Narendra watched her until she disappeared around the corner. He spotted a cab and waved it down. In the back seat he stared at the card in his hand. "Magick Theatre." "I must be crazy," he said.

\section{TWENTY}

Hyde Park was resplendent. Children raced and tumbled across the great meadow. The late summer afternoon heat was now cooling noticeably. Dwayne was in a fine mood as he strolled. He felt like a part of history. There would likely never be another opportunity as juicy as The General. Dwayne felt something greater. The word for this new feeling escaped him. He had rarely felt this good. He kicked at the gravel on the path and looked to the clouds for inspiration. Yes, he felt... privileged. He had made more from the dismantling of the General than the sum total of the lifetime salaries of all of its CEOs from the very first day this grand corporation opened its doors. On the General Electronic Wikipedia entry, someone would note its cataclysmic downfall. There ought to be a footnote, Dwayne figured, which pointed out that, if The General were a lady, then Western Trust had bent her over one of her own washing machines and fucked her in the ass while they strangled the life out of the little bitch.

Dwayne was on a path straight across the meadow when he saw a young man dressed in a hooded robe fashioned out of some sort of sacking. As the fellow drew near, Dwayne remembered Fred. This one was taller than Fred and stocky. He held a long bamboo walking stick topped with a ball of opaque marbled glass the size of a small orange. He was walking slowly, as if in contemplation. At the moment they passed he looked Dwayne straight in the eyes and nodded.

"A fine day it is," the fellow said.

"I can only agree," Dwayne said. He turned. "Wait a minute." 
The young man stopped and turned back.

“Are you a silver...?” Dwayne said.

“...surfer? That I am, sir. Can I be of some service?”

“That supposed to be magic?" Dwayne pointed at the ball on top of the staff.

"It's supposed to be backup."

“Backup of what?”

"From what they tell me, of pretty much everything."

"That would be a trick. Are there a lot of you surfers around here?"

“Not so many."

"Then you might know this kid I met in California. His name is Fred. He was headed this way."

The fellow thought for a minute. "Not Fred from Lancaster?"

"Nope. This would be Fred from Goleta. Does there happen to be one of those granges nearby?"

"There's one just up in Notting Hill." The fellow pointed. "Probably some hundreds in all of London. Not very many around here though. Property values the way they are."

"I thought not. Have a good one." Dwayne turned away.

"You too. Enjoy your stay," the fellow called to his back.

Dwayne felt vindicated. Notting Hill was hardly Kensington Palace Gardens.

$\S \S \S$

As soon as his three days were up, Narendra paid a handsome fee to be convoyed from the Castalia Gate back to New Tokyo. His convoy stopped just outside the looming gateway.

"You should be taking us through the gate," Narendra called to the driver of his lorry. "Great Vishnu in the heavens, don't stop here!" 
What if Priscilla Scintilla had ordered them to halt and was waiting to chop off his head. He imagined her standing before their convoy with her samurai sword already drawn. The driver turned and shouted through the open back cabin window, "Any passenger in possession of a weapon needs to get down here. No weapons are allowed in New Tokyo. Storage lockers are available for rent."

More than half the passengers got out and then the convoy rolled straight through Akamon Gate, coming to a halt by the side of the boulevard.

"Last stop," the driver called. "All you assburgers are home. I'm going to get me some pussy." He walked away. His form morphed into that of a large furry tiger upright on its hind legs.

Narendra's avatar strode along the broad high street of New Tokyo toward the towering Temple of Ecstasy. Until this moment, he had failed to notice that there were dark, narrow streets running beside the temple. New Tokyo was a maze of digital architecture and artifacts rudely juxtaposed at their edges. He figured these shadow areas were simply undesigned spaces between the buildings.

The Temple building was Sumerian in form, Vegas in scale, and Soapland in function. One huge sudsy, tits-ahoy, lap-dancing, pixel-grinding palace. A digital POV hentai extravaganza with a large entrance fee and any number of happy endings. Inside, its game piece beauties and beaus were as anatomically extravagant as their furry clientele were anatomically incorrect. The latter sported dicks as fuzzy and long as raccoon tails, and stiff as cricket bats. Female furries had cunts with pudenda as cute as little kitten faces, and fuzzy tails that wagged to signal their arousal index. While the Temple's digital erotics were deliberately cartoonish and frantic, the advent of biofeedback sex toys jacked their digital images into actual physical stimulation devices. The busty green Orion slave girl with her hand on your furry's dangling nuts could goose you for real with the right toy interface.

Narendra could hardly ignore the spectacle as he walked past. A bevy of anatomically delicious naked snake dancers on the Temple's front steps glistened as they gyrated under rainbow banks of simulated spotlights. Crowds of avatars dressed up as any number of species were flowing in and out of its giant front doors. He had never made it past those doors. He preferred to loiter in nearby nightclubs where actual jazz bands, videod live in bars across the planet were hologrammed onto their stages. 
Narendra was not about to meet the most dangerous hacker on the planet today while dressed as a koala bear. His avatar wore a black collared shirt and slacks. It held the red card with the code to enter the Magick Theatre. One o'clock in the afternoon in New York; it was midnight in Viet Nam. New Tokyo was bathed in its inevitable twilight.

Narendra made his way to the side of the Temple, down a dark street with tall brick walls on either side. About fifty meters in, an even narrower, darker lane appeared on the left. He could hardly see to walk, and his avatar pin-balled between the walls as the lane meandered for a good twenty meters before it turned abruptly and ended in a door illuminated by a low-wattage red light. A brass plate on the door read "Magick Theatre." Narendra held up the hand holding the card and the door swung open. The card vanished from his inventory.

\section{$\S \S \S$}

Dwayne's phone vibrated and he took it out. He read a message and opened up an app.

"This should be good," he whispered to himself. He leaned forward on his desk, the phone in his hands.

"This is Sean Rafferty with another exclusive report." The bottom of the screen reads: Financing the Communist Insurrection.

Sean is wearing a blue blazer and tan slacks. "I'm standing on North Water Street in Decatur, Illinois. Behind me, in this nondescript building is a local bank, known as a sharing union. I'm speaking with Sandra Freeman, who is the president..."

"This month..." The woman, dressed in jeans and a red polo shirt with the sharing union logo on it, interrupts him. "Next month I'm the janitor and groundskeeper."

"I see. But this month, you run the whole show." Sean gestures theatrically. The building is a simple unadorned one-story, gable-roofed, stucco structure, which could have held an auto parts or a kitchen remodel store. "How old are you?"

“Old enough to have earned the badges I need," she says, folding her arms.

“Speaking of earning. How much does a president of a sharing union make?" 
“Our books are open on the web. We all make basic wage here."

"And what's that?"

“The living wage calculated for this locale."

"You get paid that as president?"

"I get paid that for whatever role I take. Plus Shine. And then there's the profit sharing."

"That must be where the real money is, I bet." Sean nods knowingly.

“Last year I got three big ones."

Sean winks at the camera. "Three million dollars. That's something I can..."

“Three hundred dollars," she says.

"Hundred?"

"We distribute seven percent of net after-tax earnings. The rest goes back into our social loan fund."

“This isn't like any bank I've ever seen."

"What do you mean?"

"Well, it's..." He puts on a wan smile. "Kinda shabby, don't you think? Not like any bank I know."

“It doesn't look like a bank?" She looks around and then back. "It does to me."

"It looks more like a thrift store."

"Good eye. That's what it was when we bought it."

"You don't feel the need to impress your customers?"

"Our customers are our owners. We all have shares. We impress ourselves with our interest rates."

“Don't you worry about being robbed?" 
"Almost all our cash transactions are through the ATMs we have in local granges. We make loans here. We support housing and small manufacturing. People come to us because their old banks were robbing them through high fees and low returns on their accounts. Well, we did have this one guy..."

"I suppose you just gave him all your money and told him to have a nice day..."

"We gave him a job and a no-interest loan. Joe has a family. He still works here. You can come back next month, he'll be president then."

“The bank robber is your next bank president?"

"So?"

“Wouldn't your investors be happier with an MBA from Chicago?”

“Not as happy as Joe's kids."

"I have to tell you, you don't seem particularly busy today."

"How do you think you got this interview...?"

"This is a really tough time for banks. I'm certain that the..." Sean looks around for a sign and then gestures his confusion at the camera.

“...North Decatur Sharing Union,” she prompts him.

"Right...is having its share of problems."

“Our assets are growing at about twenty-five percent year to year. This time next year..."

Sean straightens up to the camera, which closes in on his face, "By refusing to play by the rules, these renegade banks are bleeding the mainstream financial marketplace of much needed capital. They try to hide in old buildings on the outskirts of society, but we will uncover their true intent. This is Sean Rafferty from Illinois."

\section{$\S \S \S$}

The Magick Theatre's decor appeared to be "early German expressionist movie set". Part Nosferatu, part Metropolis. The room was circular, its enclosing walls hidden 
behind undulating velvet curtains. Hot-white neon lamps lit the tables casting oversized shadows of towering potted tropical plants on the ceilings. On the large circular stage in the middle of the room a troupe of blonde dancers in Oriental makeup and very little else, twirled and twerked in unison to a tuxedo-clad jazz band playing a Josephine Baker banana dance tune.

Narendra noticed the waiters were all vampires. One of them, a pert young female brunette, stopped in front of him and smiled a toothy grin. She was dressed only in a gauzy, starched men's formal white shirt unbuttoned to the waist. Her nipples stood up like thimbles. Someone had paid real GitCoin to have her modded from a generic Zone piece. She carried a tray with a bottle of Absinthe and two set-ups.

"I’m looking for Nam Nguyen," Narendra said, sliding his eyes up to meet hers.

She nodded over to a table in the corner under an archway. "You're in luck," she said. A figure sat there alone, gazing at the floor show. Narendra watched her glide away, the shirt tail fluttered across the top of her naked ass.

Narendra paused. What he was asking Nam to do was nearly as absurd as the amount of money Mooney was offering to have it done. Perhaps that would be the key. Nam might take the challenge just because nobody else in the world would even consider it.

Narendra walked over and stood beside Nam's table. Nam was still fixed on the stage show. His avatar was petite, slender in a trim black tuxedo. He was as tiny as his brother Tiny was huge. The avatar's hair was brilliantined and combed straight back. A long brown cigarillo in the table's ash tray sent up a bead of smoke. A gimlet in his left hand glowed like radium infused honey. The tune ended and Nam's avatar sat back. It picked up Narendra in its peripheral vision.

"And just who the fuck are you?" Nam's voice was a staple DocDo English translation voice. He looked up at Narendra.

"My name is not important. I have a job for you. I was told you were the only hacker on the planet who could do this for my client."

Narendra figured he was being photographed and IDed, but he kept up the pretense of secrecy. "It's a very difficult, sensitive piece of work, for the right price."

"I haven't seen you here before."

"First time." 
"Who got you in?"

"She..." Narendra stopped.

“Doesn't matter. I'll hear your story now. Go ahead and sit. Our conversation is being encrypted. If you are recording it, I will find out. So don't."

"Fine." Narendra sat his avatar. "Here's the thing. My client has a daughter. She's run away, probably living in a grange somewhere. But he wants her back."

"I'll bet he's a real asshole, your client. If he really wants her back, he should stop being such a dick. Although it's probably too late for that, now that she's gone. Tell him to get used to people running away from him."

"He has this insane plan..."

"You've come to the right place then, my friend. We are all a bit psycho here." Nam gestured at the room. The jazz band had switched to a big band number and the dancers were now spread among the tables, fondling the customers. Laughing at their jokes.

"He wants to blackmail Castalia to get her back."

Nam's avatar sat still for a minute, blinking occasionally.

"He thinks Castalia is some kind of corporation?"

"He thinks there's enough at stake for the granges not to lose what Castalia provides them."

"What exactly is he threatening to do to Castalia if they can't comply?"

"Attack the service, take it offline, keep it offline until they do."

Nam was now staring at his face, the avatar mirroring the astonishment of its owner.

“Pretty crazy, huh?” Narendra said.

"I think you should go now." Nam looked back toward the band.

"You haven't heard his offer."

"Anybody who would even try to take Castalia offline would become..." 
“A pariah? A target? Sure. That's why I'm here. I was told you were already a target."

"So you figured you knew my price."

"The job pays twenty million dollars US, double that if you can do it within sixty days. There's a ten million dollar bonus for you if it works."

"You should go now, Doctor Prasad."

"You're not even a little interested?" Narendra had figured that amount of money would guarantee some level of interest.

"Not in the least."

Narendra stood. "Here's my phone number. If you change your mind within a week, let me know." He keyed his disposable cell-phone number into the chat window. After a week, Narendra figured he'd be out looking for work himself.

“Go back to your furries, Prasad. Forget you ever talked to me."

"So you don't think it's possible to hack Castalia?"

"Without getting caught? Never."

"You're already caught, Nam. Your family kicked you out. Fifty million dollars is enough to retire on. And...you'll be the guy who took down Castalia."

“Goodbye, Doctor. The door is where you left it."

Narendra noted that The Zone client user interface said his conversation with Nam Nguyen had ended. He left the Magick Theatre, walked into the brilliantly lit streets of New Tokyo and logged out.

\section{$\S \S \S$}

Ruby's Leg was abuzz after a massive shootout in the street left five dead to The Zone for a year. Four of them were from the same Capital Hill grunge in Seattle, where a fistfight had broken out the previous evening. Priscilla and Scratchy were back at their table after the show. 
"Our Dr. Prasad logged in yesterday," Pris took a full shot of rye and downed it. By protocol, she would have to do the same IRL.

"It's a bit early for me, I'm afraid," Scratchy said, and sipped on a glass of sarsaparilla. "You track him?"

Pris nodded. "He made the run back to New Tokyo. I considered killing him outside of the Akamon Gate, just to slow him down."

"We had agreed to watch him."

"He's alive, for just that reason. If we knock him out of the loop, whoever paid him will only find someone else."

"Where'd he go?”

"Straight past the Temple of Ecstasy and into an erotic theme lounge called the Magick Theatre."

"Isn't that where...?"

"You're old friend was there, according to the logs."

“Thanks, Pris. Let me know if Prasad logs in again.”

\section{$\S \S \S$}

Chelsea's work at the university cafeteria had proven as tedious as her Guide had predicted. The kitchen was a food factory and Chelsea its least skilled worker. Chelsea ran the dishwasher, mopped the floors, and cleaned and disinfected the toilets. The food here was far better than at her old high school cafeteria. This one was more like a giant cafe filled with local produce, artisan breads, and free-range meats.

Most of the cafeteria's offerings were cooked from scratch on site. The kitchen was bustling and fragrant all day. The other workers carried over stacks of empty pans sticky with baked-on pasta and sauces; along with some obligatory attempt at sympathy, they piled these beside the sink where Chelsea labored. A particularly blackened pot might arrive with a Shine stone from an entry-level chef. All pans would be gleaming by the end of the afternoon. Although she had never experienced work 
before, Samantha had watched Sheryl fly into a rage over a smudge on a wine glass. Chelsea knew what clean looked like.

There were more tears in those first months than in any time before. Sheryl used to mock her when Samantha cried. "Only the poor can afford tears," she'd say. Chelsea had new tears now; tears of exhaustion, tears of hopelessness. Some were lonely tears, not for Santa Barbara or home, but rather because she had nobody to talk with about her life. Some were angry tears. Her anger at her parents had become more focused as the contours of their neglect came into perspective. She admitted to self pity and decided that was unacceptable. So she threw herself into the dachi life. She was the star of their ultimate team, and began to enter into the Game knack banter at meals.

Chelsea worked alone with her headphones on. Mostly she listened to music or to Simon Sayz. Or she puzzled through the latest query from her Game play. Or she dreamed of triumphal return to Santa Barbara. Sometimes she cried inside.

Surrounded as she was by friends, she was also alone in her own story. She was never good with secrets, only now her whole life was secret.

\section{$\S \S \S$}

Evanna Cassidy was every inch a SilverSurfer. A green eyed ginger, she hailed from Innishannon grange \#632. Although elfin in stature at just over five feet tall, she was elephantine in her presence in her homespun flaxen robes, and in the flaming rhetoric she delivered in a brogue thick as the head on a pint of porter.

Evanna arrived in Asheville on a Monday. As she was Rat dachi, the grange manager pinged its Rat members to see who could host her. Chelsea was the first to reply. Chelsea texted Amber, who said she already had plans to stay over with her new girlfriend, Madison. Chelsea carried one of the house's extra futons up to her room, with a set of Garret's freshly laundered sheets. She was eager to meet another SilverSurfer. She had lost track of Fred. Perhaps Evanna knew where he might be found.

"Someday I'd like to become a SilverSurfer," Chelsea had just settled into her futon. "I've been listening to Simon's podcasts." 
"It's not something you become," Evanna said. She turned under her sheets to face Chelsea. A full moon shone through the window, illuminating a trapezoid on the floor near their heads. "It's more something you realize you cannot escape."

"When did you know...?”

Evanna closed her eyes, contemplated the question, opened them and nodded. "A month after I earned my shoulder bag in the Game. I was glum having lost my Guide, and then, suddenly I felt liberated to be on my own again. You see, I only took up the Game when my husband left me. Went off with a city girl, the bastard. My Guide became something of a surrogate for that man. But knowing what I had learned through the Five Skillings and the rest, I felt free to be alone. I had finally learned to like myself just enough to be fully on my own. That's when I knew I was destined to wander."

“Right now, it's just a dream for me. I'm struggling with Level Three.”

"What was your test?" Everyone had to pass a lateral thinking test at the beginning of level three. These mostly involved having your avatar trapped with no visible escape route.

"Lions and alligators."

"What's that like?"

"A pride of lions chases my avatar to a cliff. I start to climb down. Above, they are pacing and roaring. At the bottom of the cliff I spy a muddy river filled with hundreds of alligators, swimming and snapping their jaws. I cling to a root protruding from the cliff face, trying to think of a way out. After a time, some mice come along and start gnawing at the root. Then I fall and I'm eaten by the alligators. After many rounds of this same predicament, I'm clinging to the root, still hoping to find a way out, when I notice a strawberry growing in a tiny crack just within reach. As the mice chew the root, I finally decide to just eat the strawberry and my Guide appears and lifts me off the cliff."

"So there is no solution."

"The solution is to fully enjoy the strawberry. By the time my avatar nibbled it, I think I could actually taste it."

“Are you happy here?” Evanna said. 
"I'm busy." Chelsea rolled on her back. "And I'm lost. I don't know which direction to take. I haven't found a craft or passion that I can dive into deeply. How do I know if I should even be here?"

"Not everyone can stay in a grange. Perhaps you might need some more time outside or with your family?"

"You don't understand. How can you. You're..."

"I didn't even get into the Game until I was in my twenties. You're way ahead of where I was at your age. How old are you?"

"Six...eighteen." Chelsea said.

"Just a lassie then. When I was your age I left school to work at the public market in Cork. I sold chicken and eggs and kept a horrible little flat. I met my future husband when he was delivering for DHL across the south of Ireland. I've told you how that turned out."

"I want so much to belong here."

“Then you will. Soon you will need to make, or craft, or tinker..." Evanna reached across and pushed back Chelsea's hair from her face. “...just to feel the day is complete. You'll learn something really very well over two or three years, and then build a new wonderful object from your knowledge. You'll spend a thousand evenings in conversation with your dachi, spinning template knowledge puzzles and puns and stretching your knack to the point where you can dazzle a Threevey. You'll be ready to be where you are at the moment, in a manner that sockets you deep into the fabric of the place and the embrace of your gumi. You'll imagine flying off across the planet on walkabout, drifting without goals or roles for months just to clear the jets. You will reinvent yourself in five years, and then do that still again and again, each time with the same desperate intensity. At some point, you might stop and reflect that you haven't reached for your wallet in weeks, and your Shine stone bag is bulging." Evanna rolled on her back and stretched her arms out. "Jabber, jabber. Sorry, Chelsea. I do carry on.”

Chelsea rolled onto her back, her hands clutched at the sheets by her side. Her eyes were closed. She was crying softly, as quietly as she could, not wanting Evanna to notice. Crying without any reason except for a burning hope that she might feel all of these things and very, very soon. A kiss on her cheek made her freeze. 
"A good cry," Evanna whispered, "And a good sleep, you'll feel right in the morning." Again she kissed the tears from Chelsea's cheeks. Chelsea opened her eyes. Evanna's face was over hers, her long hair brushed Chelsea's face and neck. "Sleep well darling one." She moved her lips lower and planted a slow kiss on Chelsea's mouth. "Such a sweet thing you are." Then she was gone, back to her futon.

Chelsea turned to watch her settle in. "Sleep well Evanna." She reached out and touched Evanna's shoulder. "Thanks."

Evanna grinned. "You know I don't impose myself on teenagers, even gorgeous ones like yourself. But should you find your own way across this wee stretch of floor here, there is a cuddle and more awaiting you."

\section{TWENTY-ONE}

Narendra had never been up on this floor before. His own office was next to the computer server room in a florescent-lit sub-basement. The view from Dwayne's office was truly breathtaking. Narendra already had trouble breathing, as he figured he was about to be fired. He stood wavering in front of the giant glass and steel desk. He tried to ignore the Chrysler Building and waited for Dwayne to stop looking at his computer monitor.

"You got nothing for me?” Dwayne looked up and glowered at him.

"It's not the job, it's the aftermath. The repercussions..."

"How about the repercussions of you not finding me what I want?" Dwayne said.

"Maybe you're just not the right man for this job."

"I did my best, sir."

“That's my point." Dwayne looked distractedly at his computer monitor. "Here's another thing. Aren't you supposed to keep these working? I've been having problems with this thing all morning. It keeps restarting." 
“That's not good. Could be a malware attack. We should take you offline so I can do some tests."

"You really should, you know." The voice was a standard DocDo voice, coming from the computer's speakers.

"What the..." Dwayne stared at the screen. Instead of his spreadsheet, a thin Asian man in a tuxedo, silhouetted in backlight, sipped on a demitasse of coffee.

“You're security isn’t worth shit, Mooney. But don't blame Dr. Prasad."

"Narender, you're the internet security chief here. Who is this?" Dwayne gestured at the screen.

Narendra moved around the desk. He noticed a Skype call had been started.

"Dwayne," the face on the screen said. "Welcome back to New York. We haven't been introduced. My name is Nam Nguyen."

“I’m terribly sorry, Mr. Mooney," Narendra said. "This shouldn't be possible...”

"Hello again, Narendra. It's good you're here too. You should tell your boss to be more careful with his passwords." Nam looked directly at Prasad. "Dwayne keeps them in an unencrypted address book on his smartphone. Everything from his bank accounts to the code on the front door of the building you're in. Most of them are the same one. PUSSY123cat. Really?"

“Good lord," Narendra mumbled. "They never follow instructions.”

"Is this the guy?" Mooney asked. Narendra nodded.

“Mooney. I've decided to do this job you need. Here are my terms...”

\section{$\S \S \S$}

Chelsea was counting the days remaining to pay off her grange share. After the first of November, her obligation to the grange and her gumi would shrink to half-time, which would pay her board, meals, and grange and gumi house dues. Until then, she returned home in the evenings too exhausted for the Game, and took to reading from a list of books that Garrett recommended. At dinner her housemates would chime in about their latest adventures and learning discoveries. Chelsea had little to add, not 
wishing to bore them with her struggles cleaning the baked-on mozzarella out of a lasagna pan. In her waking moments before rising, Chelsea tried to dive inside her confusion to sort out some direction for her life. Getting the hell out of the kitchen had to be step one.

"Actually, step one for you is getting your maker safety badge so you can check out the maker and crafter labs," Amber told her, when Chelsea complained again about her job. "You need to spend some real time exploring what the grange can offer you, and don't be limited to this grange, visit the others too, and their factories. You know a good number of granges around here are also doing historical or fantasy themes. Maybe you need to go steam-punk or medieval. Are you religious?" That might explain everything, Amber reflected. Maybe she's missing her church.

"Not really," Chelsea said, although her dad had once accused her of worshipping shoes. "Or why would you need two-hundred pairs of them?" he said, "all still in their boxes." Silly fellow. Today, she had only three pairs. One was her Game shoes.

"There are church and mosque and hindu-temple granges too. Mostly there are people doing what they love. One day you'll see something that hijacks your desires. Have you seen One-Thirty-Seven?"

“One-Thirty-Seven?”

“Only the most famous grange in North Carolina. And it's right here in Asheville. You should check it out. You've got to find the muse that rocks your socks. That's how I got into computers."

"I thought you were born playing with CPU chips."

"Actually, when I turned sixteen and finished level two, I thought for certain I would be doing ceramics for the rest of my life. All I wanted to do was throw pottery. I joined a grange in Durham. One fine day I wandered into their computer maker lab. I never really left. You remember how gawdawful confusing it was when you were that age?"

“Not really.” Chelsea suppressed a grin. "It seems like another life."

“Everything was so very consequential. Now, I'm open to anything. I might walk into a crafter lab here and start on a new badge and a new life, and not look back until the next time I decide to start all over again."

\section{$\S \S \S$}


Chelsea found out she had to prearrange her visit to grange 137. A simple conversation with Moses was all it took. He talked with the guide of the grange's manager and her reservation for the following week was fixed.

"This is a demand sharing grange," Moses said that morning. "You should not bring anything unless you don't mind sharing this."

"I don't have anything I can share," Chelsea said glancing about her room. "All I own are the clothes I'm wearing, and I've borrowed these as well. Is that a problem?"

"No problem at all. Beware the escalators."

"What?"

$\S \S \S$

Amitabh said, "Go to the Red Star Coffee House and get your shoes; you earned them. I am so proud of you. There might even be a surprise for you."

"I can't go in there. I have no..." Joseph started to say. No nothing, his heart sank. No rupees for a drink. No shirt with a big collar, no trousers that weren't all raggedy at their hems. His pants had the broken zippers of other pants sewn on their hems to keep them from further wear. Any surprise was bound to include embarrassment and probably a beating; this would hardly be surprising for Joseph. There were girls at the Red Star. Girls dressed in saris from the malls, or even in blue jeans and silk tops, like in the movie posters pasted on street walls.

"You will be welcomed there," said Amitabh.

"Me?"

"Don't be a silly. Trust me.” The screen went black.

Joseph felt a stroke of panic. What if they tell the guards to chase him away with lathi sticks? What if they call the police and put him in gaol?

"Your turn is over. Step aside and let someone else play!" said a voice at his back.

Joseph stumbled away. The world seemed to wobble and grow dim. 
"Here," a soft voice said. A hand took his arm. A grip like a wrench.

"Ouch," he protested. The hand softened.

He looked over his shoulder. It was Meena, a girl who was often at the computer in the early morning. "You must breathe deeply and stand still," she said. "You look like you ate a frog."

Joseph took a deep breath and closed his eyes. The hand on his arm was warm and firm. Meena pulled on his arm when she leaned into him to speak.

"Is it true?" she whispered.

He could feel her body pressed against his arm. He opened his eyes a bit, looking down. She was barefoot and her short dress had faded from plaid into a flurry of dim colors.

“Did you really earn your shoes?” she continued.

He nodded.

"Nobody earns their shoes at the wall computer. They all say this is impossible."

She released his arm and her body was no longer there. He sighed and looked around into her eyes. They smiled back at him. Meena's face was clean, her black hair was pulled into thick braids that fell down her front. On her neck, at the edge of her braid, he could see scabs from bites. He lifted his hand and touched a scab under his ear. Last night, he was only pretending to be asleep. Eyes closed, his mind was puzzling through the template thread: Simple on the Outside, Simple Underneath, Simple anchors Emotion-all the way back to Choose One. He never caught the rat that nibbled on him. He had a new template for the Game: Hungry Rat is a Fast Rat.

"Who says it's impossible?" Unconsciously his hands went into the motions he had learned from Wanda. Circle the left hand, right hand to the diagonals, and then switching, and adding in the finger motions, faster now. Last week Wanda came up and kissed his avatar, saying he'd learned everything she could teach. With only fifteen minutes a day at the computer, Joseph needed to remember every picture and word, to play these back again for the rest of the day.

"And you did this in months. There are boys who have been playing Level One of Game for years." 
"Maybe the Game made a mistake." He was convinced this was true, and more: that they would all accuse him of cheating, somehow, and when he went to get his shoes they would really be very angry.

"You must do what your guide tells you," she said.

“Have you been to the Red Star?” He folded his arms across his chest and stood tall, almost as tall as she.

“Well...” Her eyes were not smiling anymore.

"I've been inside grander buildings," he said, faking confidence. His uncle had taken him to the movies once, in the large theater covered with posters near the bus station.

“They can't complain if your Guide told you to go."

"He is the best Guide in the world."

“Looking at you, I can only agree.” A smile snuck onto her mouth.

“Will you come along?” he asked.

“Me?” She looked around her, nervous.

“Just wait outside, in case."

"In case, what?"

"I don't know. Just in case."

“O.K., Just in case. But we need to go now. I have school this morning."

“Now?"

“Now!"

$\S \S \S$

"The template is called Discourse Repair." Caitlin Kerrigan looked across the mahogany desk at Harold Farmer. "It was unfolded by Simon Bishop some time ago, but suddenly there are dozens of workshops about this, all across Castalia." 
"Give me the one-pager on this." Harold sat forward. Caitlin had become his top advisor on all things Game-related.

"You know how we speculated that the Game would spawn its own political party?"

"The models suggest that tactic would split the democratic vote and only help our side."

"What if Gamers decided not to create their own party, but to join an existing party?"

"Join the Democrats? Then we would need to corral more of the independents to vote Republican. And we've talked about this before. Why are you here?"

"Discourse Repair notes that any discursive field-any civil conversation space-can become poisoned when a segment of the space descends into what Simon called 'uncritical, self-confirming loops'."

"Sounds like most political conversations I've had lately...”

"Exactly. If you look at the history of governing, you'll see that sometimes there are years and decades when nothing important happens, because of the fixed discourse of one group."

"Maybe that's a good thing."

"Not if you're a change agent like Simon," Caitlin said. "Let me read from a text that is circulating in Castalia: "The obvious targets for Discourse Repair are political parties such as the Republican Party in the US, the Front National in France, the Liberal Democratic Party in Japan, the Conservative Party in the UK, and the Christian Democrats in Germany and many others. All of these had become too enamored with their own ideas to work toward political solutions.'”

"What exactly is a 'target' for Discourse Repair?"

"The template says when you survey the political landscape and find an arena that is broken, you occupy this."

"You're saying Gamers will all become Republicans?" Harold stood up and walked over to the window. His thoughts captured the beauty of this strategy. Fifty million Gamer Republicans could sweep the primary elections. In a couple election cycles they could remake the platform, completely alienate the fringe, and gain control of the party's 
working apparatus. He looked out in the direction of the White House, hidden by the buildings across the street. That also would be theirs for the taking. He turned back.

"We need to run a whole new set of models," Harold said. "And we should call a council meeting with the other foundations."

Caitlin waited for Harold to stop talking. He said, "You think I'm missing something?"

"The Game has been political for years now. You know those annual Frolix that now happen every May 25?"

"When all those flash mobs sprout on the street and lots of people do silly things?"

"These mobs are all coordinated through Castalia. People do really silly things, sure. The point is that there are more than twenty-five million people in America doing silly things in the street on the same day. And probably four times that number do occasional frolicks organized by their granges."

"You're telling me these are just rehearsals?"

"When is the last time twenty-five million people showed up for a nation-wide political rally?"

Harold was silent. The largest political demonstration within his memory was under a million people.

"I'm looking for an assistant director. Caitlin, I hope you will consider stepping up to this role." He offered her his hand across the desk.

Caitlin stood and took his hand. "You'll need to give me time on the Game, sir. When I'm a Meister, I'll be much more of an asset for the team."

\section{$\S \S \S$}

Joseph and Meena walked along Sayyaji Rao Road past the old Maharaja Palace. Meena set a fast pace and kept her eyes on the sidewalk. The street was crowded with buses, lorries, auto rickshaws, bicycles, and push-carts. Scooters, taxis, and cars wove in between these. A metal railing along the street separated the sidewalk from the traffic. Vendors spread their wares on the sidewalk wherever trees overhanging the palace outer wall provided some shade. The morning was already steaming hot. 
Joseph still carried his sack, bulging with the morning's gleanings. He struggled to find something to say to Meena.

"We often walk this way to get to the cathedral," he said. "Look, see the towers up ahead." There were shorter routes from his home to the church, but these would intersect the traditional neighborhoods of the merchant castes.

"My amma makes needlepoint for the Church to sell. My appa makes chappals on Irwin Road." Joseph hoped to start a conversation. "I should be working. He will be angry with me tonight."

They passed the Palace grounds and the gates of some government buildings guarded by sleepy police leaning on their rifles. Well up the street a roundabout would take them to the road where the Red Star Coffee Shop awaited him.

The Red Star Coffee House on Devaraja Urs road occupied what had long been three separate shops: a travel agency, a cloth merchant, and a one-person financial services company, all fronted by a single overarching arcade built of brick and finished with scallops and curlicues of terra cotta and stucco. The building was pre-independence, a business venture from the time of the Maharaja. It was constructed to look like an outbuilding from the main Mysore Maharaja's Palace. All Joseph knew was that the Red Star was as unapproachable as the real Palace; a place where people arrived on scooters and wore store-bought clothing.

Meena walked in silence and refused to look at him. He kept pace, hoping she would say something. They waited for a lull in the traffic to cross the busy commercial street. Ahead, now, was the arcade facade. A large red star sign topped one of the turrets.

"I also know how to make chappals. I could make you a pair."

"I don't need your chappals," she said, glancing down at her bare feet. "Give me your bag. You cannot take it into the shop."

"It should just be a minute, unless there is a queue. If there is a crowd I won't enter." He left her and walked, a bit too fast, up the steps to the broad porch under the arcade. He looked back once. She waved him on. 


\section{TWENTY-TWO}

When they booted Nam out of Sao Do, they should have destroyed all the laptops he had ever touched. These were open hardware laptops. Their users swapped out their screens, chips, and drive modules to upgrade them, keeping only the chassis. Users rarely swapped out their bluetooth controller chips. Nam simply replaced these with his own design. The chips he left behind supported two channels. The first was the standard antenna and the second was a low-power antenna that talked to the small beacons he had tucked into desks and behind whiteboards. In turn, these talked to the router he left in an outdoor electrical closet that sent an encrypted stream to a server he maintained near Ho Chi Minh City. Apart from Scratchy's laptop, which nobody touched except for Scratchy, Nam had the files and keystrokes from the entire Castalia team. He knew about StormVermin as soon as Tiny did.

A couple weeks past, his beacons stopped working. Someone must have located one of them and started asking questions. That made no difference, he already knew everything they did about StormVermin. That Scratchy was a real bastard when it came to testing his team. Knocking out the mesh was downright mean.

Nam's problem was that the actual code for StormVermin was not on their laptops, only the analysis of its effects. This meant that Nam would need to reverse engineer the virus and its antidote code from the logs it produced. He would earn his fifty million dollars.

\section{$\S \S \S$}

Narendra's role in the approaching attack on Castalia was simple. He would provide two server addresses to Nam. The first was for the hack into the Castle to plant the message for them to "Send Samantha Mooney Home." This "Surrender Dorothy" approach was Mooney's idea. He had suggested a twenty-four hour clock before the actual attack. Nam came back with a two-hour clock.

"We will be lucky if they don't shut down the message in the first ten minutes," he said. "But that's really all we need to get our point across. Once we take down Castalia, all the action will happen through Junana." 
The second server was to be the source for the actual attack, obscured by a trail of proxies across three continents. Neither server was expected to survive the aftermath of this action. Once Sao Do sussed out their IP addresses, the counterattacks would be hideous and fatal to the servers.

For a couple years, Narendra attended a monthly geek breakfast with local CIOs. He liked to gab with other sysadmins, and he harvested all their gossip. Last month he was at a table with a group of university computer staff. Unlike corporations, university servers were distributed across schools and labs, with uneven security results. The $\mathrm{CIO}$ at Columbia complained the most about the anthropology and art history departments, which had not bothered to upgrade their servers' LAMP stacks in years. She worried they were ripe for any griefer attack. These servers were also both on the ultra-fast academic backbone fiber network. It took Narendra a couple hours to gain root access on both of them.

The other role Narendra took on was to steal the fifty million dollars that was meant for Nam, who had insisted on the whole amount up front. Mooney was looney, Narendra figured. Any which way this ended, Narendra would need to be elsewhere. Fortunately, when Nam broke into Mooney's computer, Mooney reacted by having Narendra help him move his passwords from his phone's address book to an encrypted system. This activity was, of course, far better done by Mooney himself, and in private. What an absolute dweeb.

\section{$\S \S \S$}

Rahas Krishna Rao looked up from the register, anchored to the far left end of the long zinc countertop. The day was almost hot enough already run the AC. In training to be the assistant manager of this Red Star Coffee House, RK was refilling the coin tray for the morning rush hour. A barista with an assistant, two counter persons, a busboy, and a peon were the employees on duty under RK's supervision. A couple of early customers had settled in a corner booth, intent on their laptops. Upstairs, the regular Gamers would soon be hanging out, their computers guzzling up the wifi.

He would not have noticed the boy, who seemed to have perfected the art of not being noticeable, except that this was the lad's third time walking past the doorway in a slow, halting stride. The boy disappeared past the doorframe and RK went back to counting out the various coins to be available as change. That very afternoon he would be 
testing for his Journeyman Level One badge in coffee-house management. If he passed he could apply to be a full assistant manager at any Red Star in India, and indeed, anywhere in the world.

The boy appeared again at the doorway. This time he turned as if to enter. RK took a closer look. The lad was dressed in clothes that were so old they had lost their original design and color. The shirt might have been yellow, now it was some shade of dust. A random assortment of buttons kept it closed. The trousers were faded blue. A cloth belt cinched them over his thin hips. They were threadbare and shapeless, as if dhobis had not simply beaten them on rocks, but also had driven some form of armored vehicle over them. The boy's face was clean, his eyes bright as they darted across the room's interior. His hands were clasping and unclasping, and he seemed to want to speak but also to flee. If he came inside, RK would need to shoo him off. That would be simple. An espresso cost eighty rupees and the lad looked like he didn't have two paisa to rub together.

The boy stepped forward, looked directly at RK, and put his hands together in a greeting.

RK was about to speak when the boy opened his mouth.

"I have come for my shoes," he said softly in Kannada.

"What is that? Speak up!" RK motioned him to advance.

“My Guide told me to come and get my shoes. I earned them this morning."

"That is hardly likely. How old are you?"

“I am eleven... Very nearly twelve!”

RK had never heard of someone so young earning their Game shoes.

The lad stepped forward onto the polished terrazzo floor inlaid with the big red star.

"Please, I just came for my shoes. I will leave as soon as..."

"What did you have for Level One?"

"Palaces."

"Palaces? I also had Palaces." RK had earned his shoes last year, and was in the midst of Level Three. He had recently been selected to join Grange 794. He was also five 
years older than this boy.

"Really! I was completely stumped by the underwater castle. Good thing my Guide is so smart."

"Your Guide told you to come here?"

"This is where the Game shoes are..."

"Yes, yes. And if you have earned your shoes, you can prove it by signing into the system. Or just show me your status on your phone."

The boy had inched forward and was now standing near the counter. "I don't have a phone."

"All I need is your thumb and voiceprint." RK held out the store's Game-terminal tablet. The boy reached out and put his thumb on the square.

“Joseph Kumbar,” he spoke.

RK looked at the display. A profile appeared. A photo taken by a computer camera showed the lad's face clearly. The Level Two completion date was that very day. He looked back at the boy and again at the screen. There was no mistake.

“Well. There you go. Congratulations...”

"Thank you." Joseph took a deep breath and managed a smile. "I myself was completely surprised."

"You are the youngest Gamer I know who has already earned his shoes. Have you applied to be in a mura and join a grange?"

"A grange?"

"You don't know about granges? Where do you go to school?"

RK's smartphone chimed in his shirt pocket. He extracted it. A long text message appeared. RK read it twice. "Joseph Kumbar recently logged into your store's system. He has qualified for a free, long-term loan of a Red Star Company Computo Tablet and any accessories he might require. Please train him on the use and care of the tablet."

The message was from the Coffee-House Management Guild Grand Master herself. Not just the local guild head; the global Grand Master. RK looked closer at the boy and 
then re-read the message. He noticed it had been sent to him and also to his manager. He studied the boy again. Joseph Kumbar seemed almost stereotypically normal. He could be any of a thousand homeless kids on the street, as his father would say: underfed, under-clothed, and underfoot. How could this boy be of any interest to his guild's Grand Master?

"My name is Rahas Krishna Rao. People call me RK. Welcome to the Red Star." He put his hands together and bowed slightly. "First things first. Tell me, what is your shoe size?"

Joseph returned the bow and looked down at his feet. He had made his own chappals. When his father found a new customer, he would simply have the fellow stand on a blank page of his notebook. Tom would trace around the foot and make the chappal to fit exactly.

"I'm probably a normal size. What do you think?" he said.

"I'm not a magician. Go over to the sizer and stand on it." He pointed to a square of opalescent plastic on the floor in the corner.

Joseph went and stood on the square. Nothing happened. "What does it say?" he called out, thinking it might be connected to RK's phone.

RK looked over the counter. “Stand barefoot. It can't read through your chappals. And clean it with a sanitizer when you are done. There, in the round container."

Joseph slipped out of his chappals and stepped on the square. A number appeared. "It says 'thirty seven'." He stepped off and opened up the sanitizer container. Removing a tissue, damp with alcohol, he carefully wiped the square. There was a small bin. He dropped the tissue in and then he stood.

RK smiled at him. "We have three styles of Game shoes: the original felt espadrille, a rubber beach sandal, and a brown formal shoe. Which would you like?"

The boy hardly hesitated. "Formal," he said.

"I'll be right back." He called over to the assistant barista. "Rajiv, watch the register for a minute."

The Game supply storeroom was in the basement. A poorly lit, low-ceilinged dustgathering space, dank in the monsoon, it was home to all sorts of spiders and roaches. 
Geckos chuckled in the dark corners. RK found the shoes first, and then went to the locked cage where the electronics were stored. He used his key to enter. The Shop had recently received a dozen Computo tablets. RK had thought they were to be gifted to their best customers. Now he realized they were for charity use. RK pulled a box from its shelf. He relocked the cage. Halfway up the stairs he remembered something and went back for another box. Arms full, he climbed the stairs, closing and locking the door behind him.

RK stacked the boxes on the counter. He picked up the shoe box first. "Here, try them on if you like."

Joseph took the box and opened the lid, slipping his hand through the tissue. He pulled out a shoe, it was brown and slim, buffed to a mirror shine. He sucked his breath in, and turned the shoe to examine its sole.

"Such fine work. I'm sure they will fit."

"I gave you a thirty eight, because you're still growing."

“Thank you, RK sahib," the boy slipped the lid back on the box and made to leave. “Wait!"

"Is there something wrong?" The lad froze and turned back.

"Not at all. I have a surprise for you." He pushed the Computo box forward on the counter. "Open it."

Joseph set the shoebox on the floor and took this new one in his hands. It was hefty. There were English and Hindi words on it that he could not read. He set it back down. The top opened from the front. Inside, nestled into molded cardboard, was a tablet computer, its glass screen anchored at the corners by four tiny bolts.

"How beautiful. Thank you for letting me look at it."

“Look at it? It's yours. Well, it's a loan. A long-term loan. But we will be needing it back at some point."

"Mine?"

"Yes, you can take it with you. But first I'll need to train you." 
"I can take it home?" Joseph's eyes widened as his hand touched the glass screen. "May I?"

“Go ahead. If it's not charged we can crank it up. Grab a stool, this might take some time."

“Time. No problem. I'm...” Joseph looked out the door. "I'm, well, not alone. I have a friend outside. Can she...?"

"I should have offered you a coffee. And your friend too. Bring over two stools. What would you like...?"

"I..." The lad dissembled. "I have not... brought my wallet."

RK's head rotated in a slow figure-eight. "This is on the Shop. Your friend as well."

"Oh my! Just one minute, please. She is only waiting outside."

\section{$\S \S \S$}

A wide reception window was located at the front of the side wall to the right of the door; the word "Here" in big blue letters hand painted on the wall above this.

"Hi, I'm Angel," The man wore a badge that said "Greeter." He was Hispanic, in his thirties, and slim. He wore a black t-shirt with red lettering: "All In All the Time.

"You must be Chelsea.” They shook. "Welcome to Grange 137!”

As Angel launched into an introduction to the grange's culture, Chelsea glanced about. This looked like a regular grange, perhaps more active than some for nine-thirty in the morning. There could be a thousand people here, all intent on what they were up to. A "busy bee-hive" vibe was fully evident. On the reception window counter, Chelsea spied three large round fishbowls. One was filled with meal stones, another with coins, and a third with small bill currency. People headed out would gather from these. People coming in would add to them. Clever.

"Let's continue our conversation at the cafe on the lower floor. I should get you a copy of our grange manual. Why don't you go on ahead? The stairs are over there to your left." Angel pointed to the interior door. "Order anything you want to eat or drink. We 
don't use money in here. Which reminds me, I'll also grab some literature about demand sharing."

Chelsea wandered toward the stairs. She had been in dozens of mall department stores like this one. The building was square, three stories tall-two were above ground on the North side, with the basement floor open to the parking lot on the lower South side. The asphalt lot was now a sea of garden greenhouses. An atrium in the center where the elevators operated was topped by a square skylight. Most of the internal walls that once separated the selling floors from the staff spaces had been removed. Dozens of windows punched through the external second-floor stucco walls. The large display windows on the ground floor added to the ambient light. 47,000 square feet of former retail space now housed a mix of learning labs, sleeping quarters, cafeterias, kitchens and public baths, and a meeting and ballroom space where the cavernous underground loading dock and storage basement once stood. On her way to the stairs, Chelsea noted that the down-escalator was going. She stepped on it and was carried off.

Midway to the lower floor, circus calliope music kicked on overhead. The escalator stopped short. Chelsea glanced around. People gathered at the handrails of the atrium's balconies.

Moses, she reflected...he told her...what did he say...?

The escalator stairs suddenly collapsed into a slick ramp. She was thrown off her feet. She fell backward hard on her ass before she slid, accelerating down the ramp. At the bottom she tumbled across the floor to sprawl face down on the faux-wood parquet surface.

Laughter and applause rippled through the building. A middle-aged woman arrived and helped her up.

"Are you hurt?" she asked. Chelsea shook her head, her cheeks grew red.

The woman leaned in and whispered, "Angry?"

“They're laughing at me," Chelsea said, her hands clutched into fists.

"At you? No, dear. How many people here even know you? They are laughing at this." She took Chelsea's shoulders in her hands and gently turned her around to face the open atrium. "Look!" 
The railings were now crowded. A silence arrived. A projector clicked on, throwing light onto a far wall. The calliope music replayed, and Chelsea watched herself on the escalator, standing confused midway between the floors. Then the floor became a ramp and she tumbled and slid, her hands thrown up, her face a mask of surprise.

Chelsea smiled and a sharp laugh escaped her mouth. It was really so funny. The crowd roared its approval.

Chelsea felt the woman's hands leave her shoulders. She took a step forward and threw up her arms in a gymnast's triumphal landing pose. She grinned up at the onlookers. Applause rolled down. She took a bow.

Chelsea turned back to the woman. "Why?" she said.

“Why laughter?”

“Why this kind of laughter? This is, I don't know, cruel?”

"Is it? Do you feel abused, or simply embarrassed? This is carnival. We need carnival more than we know." Above them, the crowd wandered back to its various pursuits.

Chelsea followed the woman to a cafe table and they sat. Angel appeared from the door marked "Stairs," and walked quickly up.

"I advised you to take the stairs," he said. "I see you've met our grange manager." He nodded at the woman, who held out her hand to Chelsea.

"Laura," she said. "Very pleased to meet you."

"I’m Chelsea, Chelsea Wilde." They shook.

“Chelsea thinks our escalator escapades are cruel,” Laura said.

"They usually end well," Angel said, turning to Chelsea. "Wounded egos mend fast around here."

"When you booby-trap the escalators, people will just take the stairs." Chelsea settled back. She noticed that people were coming from and going to the baths on this floor in various states of dress and undress. Sometimes a towel was their only attire. This is a really casual place, she decided.

"Or they learn to fall with laughter," Laura said. "There are seven different tricks the escalator hackers have programmed, and these are applied mostly at random, or, in 
your case, because your face was not registered in our database. A hundred years ago George Tilyou created the 'Insanitarium' on Coney Island. At the end of several other rides you had to pass through this passageway to exit."

"What was it like?"

"Think blasts of air up your skirt, tilting floors to send you tumbling, and clowns with electric prods..."

"Yikes!"

"At the end, you could join the gallery and watch others."

"And laugh too. OK. I can see that."

"The idea of mechanical stairs was too much of a temptation for our technicians. I have to say, you handled it well. Are you applying to join?”

"I'm still a Threevey," Chelsea said. "Angel said you only accept Fourveys and above."

Laura nodded. "That time will come. When it does, have your guide contact mine. I'll see what I can do." She stood, nodded at Angel and walked away.

They ordered cappuccinos from a waiter. Angel talked about how demand sharing worked. His explanation described the opposite of how Chelsea thought it should work.

"So, giving someone something isn't sharing?" she said. "Like giving a homeless person some cash?"

"There are a lot of flavors of how people think about sharing. Many people do think that charity is a form of sharing. Real sharing is when people can ask you for things that you really value. Do you feel good after you've given away a couple dollars to a homeless man?"

"Sure. He can certainly use it."

"Your good feeling is a return gift. You get something back. Demand sharing does not imply any reciprocity. No need to say 'thanks'. And..."

He paused, his left elbow on the table, index finger pointing up. “...you don't really know the homeless person, right? So you are not in a long-term sharing relationship. If he came back and asked you for a hundred dollars, would you give it to him?" 
She sipped at her drink. "No way." She shook her head. "He'd probably go buy some drugs. How would I know?"

"Demand sharing is a practice based on a long-term recognition that everyone has needs, that these needs vary over time, and that occasions arise when anybody should be able to ask for what they need. It also means that every object we own can be requested by others. We also get occasions to make our own requests. The crowd exists to support our needs too. All that we have is merely what we can share." Angel held out his hands, as though they could grab the whole room.

"Charity is gifting but asking for something is sharing?" Chelsea thought for a moment. "What about people who just ask, and ask, and ask, and never contribute?" Angel laughed. "That's everyone's first question. Two things I need to say. People generally find that the ability to just ask for anything they need is so..." He gestured, searching for the term. "...liberating, that they begin to value their position in the group a lot more than they might have imagined they could, and more than any object they might own. This feeling supports a culture of mutual respect. It's like we are all glued together into a single whole that takes care of all its parts. It just fits right, like a comfy pair of jeans."

“That sounds a bit, um—cult-y—when you say it like that." Chelsea said.

"I know, it really does!” Angel laughed. "But that's one entire side of it. It means this culture is not for everyone. Plenty of people pack up and leave after a few months. Every occasion for demand sharing is a time of personal interactions. The other side is this: you get selfish and people will walk away. We do have a process for kicking people out. It happens. Mostly we make it hard for people to get in. You have to live and work here for three months straight before your dachi votes you in or out..." Angel looked above Chelsea's head. "Hi, Hannah."

Chelsea turned her head. Standing directly behind her was a girl about her age who had her right hand up in a hello wave. Hannah, her brunette hair still hanging wet over her shoulders, was naked apart from a white terry towel about her hips and flip-flops on her feet.

"Hannah, meet Chelsea." Angel said. Chelsea twisted and gave her own awkward wavey welcome. 
"Chelsea. Hello, hello." Hannah sat in the chair Laura had vacated. She looked over at Angel and back at Chelsea.

“That's a great shirt," she said. She reached and touched the cuff.

Chelsea looked down. A while back she had managed to snag this good-fitting, somewhat ancient, powder-blue Ryan Michael shirt from the clothing sharing room at her grange. It was her favorite.

"You like it?" Chelsea noted that Hannah was about her size on top.

“Do you mind?” Hannah leaned forward and began to unbutton the shirt.

"Woah!" Chelsea looked over at Angel for guidance. He had leaned back and was laughing to himself behind his fingers. She wondered if he had planned this.

Hannah worried at the buttons a bit. Chelsea considered knocking away her hands. Instead she went with it.

"Let me." Chelsea undid the remaining buttons and pulled her arms through her sleeves. She handed the shirt to Hannah, who stood, and, walking away, slid into it.

Chelsea watched her go. Hannah never even turned back.

"You're welcome," Chelsea called to her back.

Chelsea wrapped her arms over her bra, hooking her hands around her biceps, and looked about. Nobody seemed surprised at what had happened. She remembered she was wearing a nearly transparent Agent Provocateur bra from Harrods: the only personal item remaining from her Samantha days.

“That wasn't a gift. She needed a shirt," Angel said. "You shared yours."

"What she needs are some manners," Chelsea said. "Now I need a shirt."

Angel sipped at his latte. "Hannah is like that." He shrugged.

She leaned forward over the table. "I said, 'I need a shirt'." Angel nodded. Setting down his coffee, he shucked his black t-shirt over his head, holding this out to her.

Chelsea took his shirt and slipped into it. It was way too large, but better than halfnaked. 
"Did you tell her to take my shirt?"

"I’m not that clever."

"I'm thinking I'd better go before somebody demands my jeans."

$\S \S \S$

Standing with his bag at her feet, Meena was in the middle of arguing with herself as to the meaning of the length of time Joseph remained in the Red Star Coffee House. On the fortunate side, he had not been tossed out the door. On the other side, he might have been detained for the arrival of the police. The unknown factor, she considered, was the amount of inattention he was receiving from the proprietors, who could take the opportunity to make him wait, simply because they knew they could. She regretted holding his bag, which meant she could not simply leave. But she was still not prepared to go to assist him. Joseph was correct. They had no business in the Red Star Coffee House. She could see a poster in the window with a fancy drink topped with whipped cream and a price of one-hundred seventy rupees. She shook her head.

At this very moment, Meena was supposed to be in school, a class run by the older sister of a friend in the neighborhood. On days when she wasn't working, her amma paid ten rupees for Meena to sit and read from the text book. Without a dowry, Meena would need to attract a husband through her education and job prospects. She had peeked into Joseph's bag at her feet. It contained nothing but street refuse, shards of rubber, empty cans and bottles, and plastic containers and wrappers.

Suddenly Joseph was back out on the veranda, and then running down the steps toward her. He looked panicked. She grabbed up the bag turned to sprint away with him.

“Meena, no! Wait.”

She turned back. Nobody gave chase from the store.

"Come with me," he said. "They are making coffee for you."

"I'm late for school." She held out his bag.

"You must come and see my new computer." He touched her on the arm. "It's all too wonderful!" 
"I have to go now. I'll see you in line tomorrow."

He took his bag from her. "That's what I'm trying to say. I won't be there tomorrow, or ever again. I have a computer. You can use it any time you like! As long as you like.”

She turned and spoke. "You told them you had a bag of garbage you could trade and they offered a computer? Let me see your head."

"My what?"

"I want to see where they hit you with a stick."

"Nobody hit me. And it's true. I have my own computer. And he is making coffee. Come inside with me."

"I'll see you in line tomorrow." Then she turned and was gone into the crowd down the street.

\section{TWENTY-THREE}

"Honestly, you just missed him. He took a shared car to Baltimore to catch an Atlantic AirShip.” Megan listened to the familiar lilt of her mom's voice.

"I know, mom. He texted me. I'm calling to talk to you."

"Instead of texting? I wasn't sure you remembered how."

“Do you have a few minutes?”

"Sure, lunch is not for an hour. You don't sound well. Are you all right?"

“Apparently I'm feeling just like I should feel.”

"I don't follow." 
“Being seven weeks pregnant, and all."

"Pregnant! Meglie, how did that happen? Forget that. Tell me how you're doing, and don't be brief."

"Nick had decided to do this walkabout and we had just a week or so before he left. He was trying to show me how sorry he was, going away on his own like that. He showed me several times. I think we might have broken some kind of record, even for Burning Guy."

“When you first introduced me to Nick you said the funniest thing. You said, 'We're a couple in every possible way.'”

"Well, we just invented a few more. We always try to be careful. Then there was a day in there when things got really bright and hot and crazy and I'm sure I don't even remember all of it. Might have been something in a jug of wine someone passed me..."

"I wish I could say that sort of thing never happened to me, but you know..."

"...by the day of the burn, everything had become, well, really intense. The food we shared tasted better, even his jokes got funnier. Maybe this whole walkabout notion was not a bad idea. As the days went by, we just kept getting more and more into each other. It was almost as good as that first week we met in Westwood."

"But he still went away."

"That was never in doubt. Only he doesn't know about this."

"You haven't told him? Megan..."

"I will certainly tell him. In time, you know. Before there has to be a decision."

"Sooner is really better, if you go that way. And whichever way you go, you have our full support."

"I know."

"Really."

"I know...yorp."

"What?" 
"Shit! I just threw up a bit, right on my t-shirt. I have to go change."

“Do you want me to come out to Santa Barbara?"

"Don't be melodramatic, I'm fine."

"You have to tell Nicky."

"I know. So don't you go telling him."

"I love you, so does Winston."

"I know. I'm going to be sick again. Talk to you soon."

\section{$\S \S \S$}

It was noon when Joseph arrived home. The Computo was tucked into its waterproof carry case, the gravity-run electricity generator still in its box.

Joseph's family's home consisted of three side-by-side structures, hand built by Tom from scavenged bricks, and with a shared tin roof. The huts were backed by the side wall of an abandoned Mariamman temple, perilously close to the Mysore Ring Road near Chamundi Hill. For years the ground where they now stood had been a temporary parking spot for lorry drivers looking to take a quick piss on the shaded wall. Joseph's amma, Sarah, was silently worried that, on some new moon night, a drunk driver might not notice their shacks and mow them down in the darkness.

The long-neglected temple compound was in disrepair, its front gate padlocked and its ownership under legal dispute. This dispute was decades old and had already cost more than the value of the land, but it prevented any demolition or construction. Nobody had the energy to care when Tom acquired a bit of the outside sidewall for his family's use. Tom and his family had just been burned out of a Christian settlement near the Kaveri River by a Hindu mob chanting "Jai Hanuman." Joseph's older brother, also named Tom, was killed in the melee. Dying with him was Joseph's father's vision of another generation of Tom and Son Chappals. Tom's father had also been Tom. But now that family line was as broken as Sarah's heart.

The larger, left-side enclosure was for Joseph's family. In the middle was a small godown for the rubber and hides. Its solid door was always locked against dacoits, although Joseph sometimes wondered what sort of thief would steal rubber scraps and 
bits of water buffalo hide when there was a wealthy housing project just across the Ring Road. The right-side hut, newer and smaller, was for Joseph's uncle, his amma's older brother Anuj and Anuj's grown son, Joseph's cousin Pradeep.

Anuj had been a coconut wallah on the corner where the Ring Road met the Kozhikode Highway. A year ago he chopped deeply into his left forearm opening a coconut while drunk. The wound had festered, resulting in the loss of the hand. That was several weeks after his wife's malaria caused her kidneys to fail. Anuj still drank, but now he occasionally worked preparing the hides for Tom and Son. Sarah made a bit of extra rice and pickle for him every morning. Pradeep was old enough to find day work. He was mostly good at loitering at a cheap tea stall in the main road, getting high on white-out, and stealing trash from smaller thieves to sell to the recycle shops. He had been good friends with Joseph's brother. In Joseph's mind Pradeep had never explained how he managed to run away while Tom got waylaid and bludgeoned.

Joseph's family's hut had a small fire pit near the outside wall, where a window space was protected by a rough metal grill made from welded scraps of recycled concrete reinforcement rods. The grill was fine enough to keep out the monkeys that occupied the abandoned temple. They would scamper across the tin roof in their chasing games, and reach through the window bars at anything they could grab.

"Might as well be elephants," Sarah would say. "All the racket they make. Between the monkeys and the traffic who can even think about sleeping?"

An old blanket on a rope diagonally divided the one room in the evenings, when Tom and Sarah finally lay down to sleep. Joseph, Mary, and Miriam slept on roll-out mats near the door.

The Mariamman Temple's perimeter wall also gave the girls a large surface on which to dry the cow-dung patties they made for the cooking fire. A convent just a kilometer away had a tap where Sarah and the girls collected water each day. A nearby tap was controlled by the BJP, who charged a fee. The track that led around to the back of the temple and then the foothills of Chamundi Hill was convenient for their personal business. An ancient, towering ficus tree overhung the wall and provided shade for the bare ground beside their hut.

Joseph spent most of any day in this shade on a small wooden stool with his hammer and a metal punch pounding decorations into the stiff buffalo leather of the chappals. Saturdays and market evenings he did this at his father's stall in town. Uncle Anuj had 
a rope charpoy bed against the temple wall where he dozed or smoked bidis.

Sometimes Anuj's friends would come by to play dominos and chew betel leaf they bought from one of the carts along the Ring Road.

Joseph undid the latch on the hut's plywood door. Sarah and the girls were out, likely up at the cathedral delivering the week's needlepoint and picking up their payment in rice. Anuj was napping on his charpoy outside.

The bundle of chappals in the godown awaiting their decoration were nowhere near Joseph's attention as he closed the door and booted up the Computo alone for the first time. He fitted its headset over his unruly tangle of hair and leaned against the brick wall under the window, the tablet on his lap.

“Hello, Joseph,” Amitabh bowed and smiled. "Are you ready for Level Three?”

\section{TWENTY-FOUR}

Megan was pretending to drink her afternoon cappuccino in the Red Star lounge at the grange, looking over some weekly open roles on her pad. She had started to feel extra vulnerable with Nicky gone. At least that was how she aggregated all of her fears and sadness. Sleeping alone was harder than she had imagined it would be. She had just finished the worst chore any grange manager has: the exit talk.

Lisa Knox, a Level One Journeyman crafter, had not paid her dues and materials fees for three months. She had lost the confidence of her team in the factory, and was not selected to join them when they bid for new work. She picked up open roles on the daily slate, but then got into arguments when her output failed to hit its quality marks. There were other complaints from her gumi and dachi, complaints that were normally handled one-to-one, unless mediation was called in. And when that failed, it was Megan's job to let Lisa know what her options were, including counseling. As this was the her third visit with Megan, it was time to tell Lisa that the grange was no longer her home. Megan gave her the check, cashing out her full share and all outstanding 
pay, all of her accrued bonus jikan, and a settling of debts from her gumi. Lisa would keep all the Shine she had earned, and, of course, her badges. She was free to join any other grange she wanted. Not getting an introduction letter means she would have to answer some questions.

"I'll just fuck it all up again," she moaned. "My mom thinks I'm a loser. I grew up in Orlando. She keeps sending me pictures of the houses my high-school classmates are buying, with big lawns and two cars. They've got kids and jobs. And..."

Lisa frowned, looking down at the desk. Megan waited. Perhaps this was a moment of decision for Lisa, long coming and worth having.

Lisa looked back at Megan, imploring her sympathy. "Some days I want that too. Is that bad? I hate my roommates. Not because of them, but because I don't want a roommate. I don't want open roles and fucking Shine. I still want a job with a title and a husband with money, and everything I wanted when I was twelve. I can't help it."

"You've got some Shine and your cash. Why not take an AirShip somewhere and try to work out what you need to do next. Maybe a different badge would help. Perhaps you should take some time out in the rest of the world. Granges aren't for everybody." The rest of the world. Grangers were texting this as TRO2.

"Can’t I just stay here a while longer?”

"We've been there and done that. Don't you agree?"

Lisa closed her eyes and nodded her head, tearing. "I never meant to let anyone down." “An Agreement Makes Two Promises," Megan said. This template was the heart of self management at the grange. One promise is to your team, the other to yourself. Every broken agreement makes two wounds. Megan could see that Lisa was wounding herself by staying. "Sometimes..."

"I don't want your goddamn templates. I am so done here!" Standing, Lisa grabbed up her check. "Biggest mistake I ever made was earning my shoes. By now I could have had a real job somewhere."

“We all wish you the best, you know.” Megan stood too. She held out her hand.

Lisa looked at it and turned away. She slammed the door behind her. 
“That went well," Megan said to the now-empty room and sat back down. At least when they boot the serial worst-performing dachi once a year, the members know that Tension at the Edges cannot be ignored. There are plenty of new granges looking for members and lots of stories on Junana of booted dachis that came back strong somewhere else. Megan really hoped that Lisa would find what she was looking for; and then be happy with what she gets. That's always the rub.

\section{$\S \S \S$}

Megan was down to a single cup of coffee a day, which her obstetrician said was all right. But if she skipped the performance of drinking coffee in the afternoon, Felicia was sure to suspect something. Megan could not yet decide how to tell Nick, but she figured procrastination and gestation were on a collision course. Except for Claire, she couldn't tell anyone else until Nick knew.

Megan glanced up to see Felicia standing close and looking down at her.

"I’m fine," Megan said and took a mock sip from her cup.

"You are fine, and I think that's why he's been covertly staring over here."

"What?"

"Says he's drifting around after Burning Guy, headed up the coast to get back to Canada. He asked about you."

Megan peeked over toward the window where the man was sitting. "Asked how?"

"'If you had a boyfriend' how."

"And you said..."

“'Not at the moment,' I said. I told him your fella took off on walkabout a good month or so ago."

Felicia took a long look at the man, who noticed her attention. Then Felicia looked back down at Megan and back at the man and tilted her head as if calling him. He stood up.

“He’s standing up," Megan said. 
"He would do that first, if he wants to walk over here."

"What do I do?"

"Act horny. That usually works for me," Felicia said.

"I'd say that always works for you."

Felicia was a serial flirt who taught Dr. Lu body work classes when she wasn't a barista. She had a classically pretty face, long blonde hair, an ass like a Fuji apple, and the core strength of an anaconda. Any one of these factors was usually enough for a handsome boy on walkabout to give her his full attention. As a package it meant she had her pick.

If Nicky were some walkabout stranger who showed up here, Megan was certain Felicia would waste no time commencing to ride him like some county fair pony. Nick had retained his surfer looks and figure, and had added a jolt of exceptional Game knack to his conversation. Best of all, he was fun to be around almost all the time. And he loved to kiss. Megan figured there were Felicias in every grange he visited. Her mind offered up an unwelcome vision of Felicia puckering up her lips for Nick.

"I will leave you two alone now. My work here is done." Felicia wandered over to the espresso machine to help a customer.

The man stepped up to Megan's table. "Are you waiting for someone?"

She looked up at him. "It's just me. I'm getting a little work in."

"You work here?"

"I'm the grange manager."

"I'm passing through town on my way north. This is a really pretty place." He looked around. "Maybe you could tell me what I shouldn't miss while I'm here."

“I’m Megan. Have a seat.”

“Billy Preston.” He settled into a chair.

Megan watched him. He was very well dressed. At the WT stores there were a number of boutique brands that offered bespoke tailored clothing with a very high WholeTale number and an even higher price. Aunt Alice in Kyoto had put Megan on an email list to the site that announced the latest WT fashions. Billy looked like he just walked off 
one of its webpages. He was not movie star handsome, but he was nerd cute. Lanky, well groomed beard, super glasses, big brown eyes, and dark, dark skin.

"Billy Preston. My mother had a CD of yours when I was small."

"No relation. When I sing in the shower the soap tries to escape."

Megan smiled. So he could joke too. He looked about her age or a little older.

"I love your shirt. Look at that stitching," she said. Billy's shirt was a soft opalescent white with light blue stitches, and some stitched decorations on the lapels.

"I picked this up in Oregon. It's got a hundred score."

"A hundred. Sounds expensive."

"I'll wear it for decades. The fabric is hemp from Alberta. There's a slow-fashion coop near Bend that makes them. It's got a back seam I can let out when I put on the pudge ten years from now."

"You plan ahead for pudge?"

"You should see my dad." He made a big belly gesture with his hands. "Kenyan food is really rich." Billy looked out the windows toward the farm. "You manage all this? I've visited a number of granges and I can tell you, this one is tops."

Now she was worried. He knew how to flatter her. Right where it counts.

"I do take all the credit. The other thousand people here always wait for me to tell them what to do."

"Modest and pretty too. If you can dance, I'm concerned that your ex-boyfriend may have been an idiot, leaving someone like you."

"Actually, he's the dancer..." Megan looked down at her coffee, holding back a sob. I'm the idiot, she figured.

"Now I owe you a dinner."

“What?" She looked up.

"It's a rule. You make a woman sad, you owe her a dinner. I was going to offer anyhow, but now it's really out of my hands. You have to come to dinner with me." 
"I do?"

"When do you get off work?"

"Five thirty, but..."

"No buts allowed. I'd ask you what your favorite restaurant is, except that would not promote the whole idea of me surprising you."

"You want to surprise me?"

"Surprise is the essence of delight."

"That it is." She attempted a smile. "I could use a bit of delight."

"Where do I pick you up?"

"I have to go home to change." She pulled a post-it from her pocket and wrote her address on it. "Is seven OK?"

"Seven is perfect. Put on something evening-like, and I'll find a car and pick you up at..." He glanced at the post-it and back at Megan. "...the most famous address in the known universe. You live in Scratchy O’Hara's house?"

"His guest house, over the garage."

“Twenty-three Lotta Vista Lane. Wow! I think we'll have a few things to talk over at dinner."

Billy held out his hand. Megan put hers in it and he gave her a really good handshake. Not too hard and not at all moist. Firm and friendly. Like his smile.

"Should be fun," she said. "Dinner, and all." She found herself breathing a little harder. She was thinking, perhaps I'll take a couple dozen selfies with Billy for Junana, just so Nick doesn't think I'm too lonely.

"Ciao!" he said and walked off. She watched him go. The bespoke jeans were working. Dinner and what? she wondered. She hadn't been on a first date since she was sixteen. And she was a lot older than sixteen. She looked over at Felicia who was grinning her, "I know what you're thinking," grin.

\section{$\S \S \S$}


"Do you have an entry-level maker safety badge?" This was the first question any stranger got when she entered a crafterspace.

The fabric crafter lab at Asheville Grange 405891 occupied what had formerly been a check-cashing, quick money store in this eighteen-store strip mall. Each of the store spaces was an identical twenty-four by eighty-eight feet, including a couple restrooms in the back. The fronts were mostly glass, and a back door led to a narrow service corridor. The mall had been in decline for years. The Money-Now store was one of the last remaining tenants.

When the Grange won the building with a bid to the County for the arrears in taxes, the property was in poor repair. Still, it offered almost fifty-thousand feet of usable space on a four-acre lot. By punching through some of the interior side walls, they could make a decent grange hall. At first, the city was less than happy with the designs for the public baths. When six thousand grangers from across Asheville showed up to the public meeting for the proposed redesign, the planning and zoning commission had a change of heart.

The fabric crafter lab was next door to the furniture maker lab, and they shared the large fabric laser cutter. On the other side of the furniture lab was the wood shop, and then the metal shop, the machine shop, the materials fab lab, and the electronics shop. On the far end of the building was the transportation sharing service and next to that the equipment and tool sharing room. Next to that, a large room had been made for a variety of crafts, from pottery to digital post-production. Then there was the kitty-cat room and the mail room. Many of the members had their mail delivered to the grange where volunteers sorted out the advertisements for recycling. The near end held the large meeting room with the sound system and projectors, the kitchens, media sharing, day-care service, a mini-general store with a sharing union office and cash point, and the public baths. More than an acre of the original parking lot was being prepared for permaculture-driven, green-house cultivation. Photo-voltaic panels covered the rooftop, and a hydrogen storage facility would soon be built on the far edge of the property.

Chelsea nodded. The safety test exam virtual course had been mondo gory. Every time her avatar forgot one of the guidelines, limbs were mangled, eyes were pierced, blood fountained. Then there was the final exam in person with a journeyman crafter, where 
she had to recite all the rules and defend each rule, and show how the rules applied to a dozen different machines.

"Come on in. I'm Mandy. Mandy Ponder. This is my shop." Mandy was hefty, middleaged, but sharp and quick. She came over to the door and put her hand on Chelsea's shoulder, guiding her into the room.

“Chelsea. Chelsea Wilde.” Chelsea allowed Mandy to propel her toward a table where a portable sewing machine was unattended. The room was cluttered with machines of many sizes and configurations, most of them being used. Bolts of cloth lined one wall, cupboards for buttons and notions lined the other.

"How long have you been sewing, Chelsea?" said Mandy.

"I've never actually tried before." Chelsea had already bought more clothes than most women would purchase in their entire life. Her mom always told Samantha she had an eye for fashion. So she figured that might translate to a knack for sewing.

“O.K., and what do you want to make?"

“A pair of jeans," Chelsea said to a chorus of muted laughter in the room.

"You're talking to the right woman, honey," someone said.

Chelsea looked around. "How is that funny?"

"You got to crawl before you fly, darling. Making a custom-fit pair of jeans takes some serious skills."

"All the people you see here are working on their sewing badges," Mandy continued. Chelsea looked around the room. Dozens of crafters were actively sewing. Others were at the cutting tables. Some kind of skill demonstration was happening in the back.

After her visit to Grange 137, Chelsea had worked out that all the granges she had encountered used the logic of demand sharing - not as fervently as 137, but just as sincerely. Chelsea could step into any of the crafting/making studios and demand the equipment, material, and the knowledge she needed to make anything she needed. And she would listen to demands made upon her and do whatever she could to meet these. Sharing on demand, sharing without noticing, this practice placed her into a society of friends, real friends. Another first in her life. 
"If you commit to working on a badge, we can find a space for you and a mentor. If not, we can loan you a portable machine to use at your house and point you to online resources to help you experiment on your own. Once you get a badge you can also apply to work at our factory."

"So this isn't the factory?"

"Here we make what we wear as we hone our skills. At the factory we sew quality goods for the WT stores and for local general stores and fulfillment of contracts we negotiate at the Bourse in Castalia. We pay basic wage and share the Shine."

Mandy went to her desk and picked up a card. "Here is the URL for our guildhall on Castalia. Take a visit and you can learn about all the badges from spinning and loom minding to bespoke tailoring. Feel free to walk around and ask questions. And again... welcome!"

Mandy took Chelsea's hands in hers and locked her gaze on Chelsea's eyes. "Someday you will be a great crafter. It's a privilege to be here at your start."

\section{$\S \S \S$}

Billy Preston was not hard to locate on Junana or on the Internet. In fact, he was about as famous as anyone. William Preston was the inventor of the nanofoam that was the technology behind the use of Hydrogen in AirCraft. William and his team founded the Flying $\mathrm{H}$ Corporation and licensed their HydroBricks to the AirCraft makers and airlines. William was a bachelor and a Fiver.

The internet declared Billy to be a billionaire. Megan quickly browsed a dozen stories about him. His sharing union account in Vancouver had more than seven hundred million dollars in it. He had approved all of it for social loan collateral. But he kept his private life pretty much to himself. When he was just an infant, his family had emigrated from Kenya to live in Vancouver. He went to Rensselaer Polytechnic to study materials and ended up patenting the technology that made hydrogen aircraft safe and economical. They say his invention will revolutionize air travel. Billy was still footloose, living off the returns of his creativity.

"Young, brilliant, and rich," Megan whispered to her computer in the bedroom at home as she glanced down the pages of photos of Billy. "And picking me up in fifteen 
minutes." She went to her closet, rifling through the dresses. None of them seemed sexy...

"What am I doing?" She stepped back. She really wasn't looking to shag the billionaire. Or was she? She considered getting some advice from her Game guide, Bobby. He knew her almost as well as Nick did. Then she figured that Bobby might not know what to tell a pregnant woman who was considering a one-night stand while her boyfriend was away, perhaps for good. Not many templates out there for this kind of decision. First things first, she figured. Dinner.

Megan's mom, Claire, had always sworn by the little black dress. When the WT came out with one that rivaled the Dolce \& Gabbana number Claire once wore, she bought this for Megan. Megan was currently somewhat larger on top and with a bit of a bump, so it was a tight fit. She took a long look in the mirror. Her self image oscillated between debutante and call girl. Megan was combing back her hair, pinning it behind her, when the bell rang.

Billy had added a faux-suede blue jacket and a thin red tie to his former attire. "I can't believe you live here! I'm going to need the whole story. And, can I say 'wowsa'!"

“Thank you, kind sir." Megan shivered a tiny excitement twinge. "Down boy,” she whispered to herself.

He led her to a Noël self-driving coupe and held the door for her.

"Where are we going?” She asked when he got in.

"Just up the road, on the hillside, a restaurant called the El Enchanto."

“That's actually a hotel," she said. A really expensive hotel she had only heard about.

"With a fully blue label restaurant," he said.

"Which I'm told is excellent." Megan took home a working wage, and ate out at gumi cafes.

“So, are you surprised?"

"Not entirely, you see..."

"You've been on the internet."

"Well, duh...?" 
"So have I," he said.

"I see."

$\S \S \S$

Joseph carried his Computo tablet everywhere, concealed in his gunny sack, swaddled in a torn piece of an old lungi. Pradeep had already seen Joseph with it. Joseph didn't want his cousin anywhere near his Computo.

"You could let him use it sometimes," Sarah said.

"He is in no way sufficiently careful to handle such a delicate device," Joseph ruled. "Remember the Bajaj?”

Pradeep had spent every rupee he had or could borrow to buy an ancient broken scooter off a widow. He pestered those of his friends with mechanical skills to help revive it. When the motor was finally started he rode away, so proud, just for a spin. He returned an hour later limping badly. He had opened up the throttle on the Ring Road. A tree root pushing up the tarmac caused him to wobble and then careen. He was thrown to one side and the Bajaj to the other. Fortunately it was the Bajaj that went under a bus.

Miriam and Mary worshipped the Computo in an almost Hindu fashion. Joseph was certain they would do puja to it if that's what was needed so they could use it. The Computo came with a dozen learning games for their age group. Joseph loved watching them soak up the knowledge it served them.

Joseph's appa never showed any interest in the Computo, preferring to listen to his radio or smoke bidis and chat with those who happened by. Sarah occasionally glanced over the shoulders of the twins as they navigated through the puzzles and giggled at the cartoons. Joseph had the idea she would like to join in.

Before bed, Joseph plugged the Computo into the gravity-powered electric generator. Then he would heft the sand-filled bottle and hook it to the short end of a strap that unwound ever so slowly over several hours as its weight drove the spinning rotor. By morning, when the bottle touched the ground, the generator would have delivered more than five hours of battery charge to the Computo. 
Joseph no longer detoured past the public school with the wall computer. For some weeks he passed by on the other side of the road, hoping to see Meena. He clutched his gunny sack tightly. Any of them waiting in line for their ten minute visit would surely chase and beat him to steal a Computo of their own. He was faster than most, but also smaller than the fastest. He had so much wanted to show Meena. She never once came back.

Now that Joseph's Game sessions were longer, Amitabh pushed him faster and deeper into the Queries. Each template connected with its neighbors in ways that carried significance well beyond young Joseph's ken.

"That is a question only someone as ignorant as you would ask," Amitabh said and shook his finger at Joseph.

"If that is so, then you must lead me to more knowledge," Joseph said. "Are you not my guide? Have you been lazy and neglectful? What kind of a guide are you?"

"You need a curriculum."

"A what? Why can you not speak in words that make sense?"

Amitabh's form gained height and years. His clothing added a wool v-neck sweater and a bow tie. "Joseph. It is time you went to school."

\section{$\S \S \S$}

Their table was near the window of the El Enchanto's restaurant overlooking downtown Santa Barbara and beyond that to the waterfront. Billy ordered a margarita. Megan stayed with sparkling water.

"I'll have one glass of wine with dinner. I'm afraid that's my limit."

"If I knew you were a cheap date, I would have picked a more expensive restaurant."

"This one is perfect." The golden hours of summer twilight were painting the city, its red tile roofs arrayed below them, in saffron hues.

They ordered appetizers and his drink came. He leaned back. 
"So, you're that Megan."

"Afraid so."

He smiled and nodded.

"You want the long version or the short?" she said.

"Any version you want to tell."

Megan told him about how her mom ran this consumer behavior agency and how Claire had met Winston at college and it turned out that Winston knew Scratchy and Itchy and Desi. He interrupted her.

"All that is in Wikipedia. Tell me how you escaped. After the video."

"We took off from New Orleans and landed in Havana. Then we found a boat to Venezuela, and from there a private plane to Vietnam. We stayed in Sao Do for a couple years. Then Nick and I got back to Los Angeles, where I became the manager of a game town and picked up the badges to apply to be a manager at a grange. I won the lottery to apply here and got chosen. Scratchy said we could stay at his guesthouse, so that's kind of it."

“Except for the 'we stayed in Sao Do for a couple years'. You were in Sao Do with two Grand Meisters, Betsy Almighty, Scratchy O’Hara, and the rest..."

“It wasn't quite Gilligan's Island. We had our routines. We had the Game, of course, and our five skillings practice. Nick took to learning drama and dance. Jack owned a local hotel and I got a job at the front desk to earn some extra cash. Scratchy was on a no-fly list so we hung out and took trains down to the delta or up to the hills above Hanoi. It felt like a long vacation, too long, really. Now it's your turn. How did you ever invent the HydroBrick?"

Their dinners came. Billy talked about getting into college and being fascinated with nano-materials and their manufacturing. After graduation, he was playing around with feather-weight aerogels in a small lab he and a couple of friends set up as their first start-up. Billy wondered if he could impregnate aerogels with various gases. He tried helium first. That was easy. Hydrogen was much harder. The molecules were smaller and the process had to be done well below the relatively low flash point of hydrogen. 
"You need a vacuum chamber. First you empty this and fill it with pure hydrogen, and then extrude a fire-retardant aerogel into this environment through a graphene nanoscreen. The extrusion process traps hydrogen atoms at nearly the atomic level. The design of the nano-screen is really my only true invention. The result looks like shaving foam, only a million times more foamy, with hardly any weight at all. Finally you freeze dry this into a solid brick. It takes about fifteen minutes."

Within a few months Billy said he had hit upon his initial manufacturing solution and was able to make stable bricks the size of sugar cubes that were soon crowding the ceiling of his lab. Scaling up to build full-sized bricks took some real engineering. The rest was just a process of improving on the original solution and getting the patents.

"You decided not to sell the technology."

"We got a lot of offers, but figured we could license this for a better return."

"How does that work?"

"Each brick is about fifteen-feet on a side, so it contains a hundred cubic meters of hydrogen locked into our aerofoam. The brick gets coated with several micro thin layers of a thin polymer to be fully gas tight. One brick equals a hundred kilograms of lift at sea level."

"So one brick would carry me..."

“...into the stratosphere, with all your luggage. Because it's a foam, it acts like a solid. This means we don't need to worry about expansion at higher altitudes. A full-sized AirCraft holds around two thousand bricks. We charge half a dollar per brick for every thousand kilometers it moves. That means we take in about five-thousand dollars when an AirCraft travels from New York to Los Angeles."

“There must be hundreds of AirCraft in flight on any day."

"Eighteen-hundred and seventy four, as of last week. Another two hundred were just added for the newly approved trans-Atlantic routes. Production is expected to expand to almost three thousand a year in a couple years..."

Time to change the topic, she figured. Billy was patting himself on the back so hard, he might crack a rib. 
"I've read some pretty nasty blogs about how you're a parasite on the shared travel economy."

Billy set down his fork and laid both hands on the table, like he was about to stand. Instead, his voice got lower.

"Financial success is hard for some people to applaud. Mostly the Flying $\mathrm{H}$ company gets great reviews for a product that's making a real difference in the world.

"It's still a big corporation..."

"Did you know that our corporation is entirely employee owned? And our equipment designs-even the formulas for our nanofoams-are all open and shared. Nitrogen filled NanoBricks are the best insulators ever made, and are entirely open for anyone to manufacture. Granges and homes across the planet are saving real energy with them. While our patent is in force, we license the use of hydrogen. All the hydrogen in our bricks came from the first second of the big bang. We use this star stuff to defy and defeat gravity. We make a product with a WholeTale score above eighty. I really believe in the triple bottom line. Have you been to the Bourse in Castalia? That's pure capitalism."

“Relax. You don't have to convince me, comrade. My adopted uncles built that Bourse and Castalia too. But you have to admit that some corporations have a lot to answer for."

"Sure. Like that old lawyer joke: 'It's the ninety-nine percent of lawyers that give the rest a bad name.' The history of multinational casino capitalism is fucking grim. But the day of the huge multinational corporation is over. We're writing a whole new chapter."

He sat back, shaking his head. "Making honest goods and services, that's real capitalism. People sharing their stuff is a great thing. This means their stuff has to be made better to be used harder. We believe in open design. You want to know how SpimeCops and SilverSurfers ride free on AirCraft?”

Megan nodded. She liked his passion. He reminded her of, well, Nicky.

"Flying $\mathrm{H}$ lets the airlines subtract the cost of providing that service from what we collect. We subsidize hundreds of thousands of dollars of travel every single day." 
"You don't advertise that part." She took another small sip of her wine, and looked over at the bottle. A couple more glasses, she might not make it back to her apartment that evening. Steady girl, she told herself.

"There are more of us around, you know."

"More Kenyans living in Vancouver?"

"More capitalists making a great living building WholeTale products at the Bourse."

"Why don't you have your own AirCraft or just your own car?”

"I believe in the sharing economy. I'm not making money to buy things. I buy only what I can't borrow to use. Having the use of a thing is almost always better than owning it. Did you ever have a boat?"

"I had a friend with a boat."

"Exactly."

She said, "That's not sustainable. Somebody has to own the thing that gets borrowed." “That's why granges are genius. Just large enough to own a fleet of bicycles and cars, and one of every power tool. Does your grange own a boat?"

"We do. We have three Hobie Cats. Members with the right badges can check them out. There's a grange down in the Funk Zone that owns a whole fleet of commercial boats. Another local grange has a couple sloops it shares."

"Bingo! Do you want another glass of wine?"

She shook her head. "I'd settle for desert and maybe a stroll down by the beach."

\section{$\S \S \S$}

"Is Mandy here?" Chelsea stood in the open bay door of the corrugated-metal-sheathed factory building. She had one day left of jikan before she would need to look for halfday work. Taking Amber's advice, she was out hunting for her muse. The fellow sat at a desk just inside, making entries on the computer. He looked up and smiled. 
"She stops by sometimes, mainly to pick up loads of denim. Mandy has her own shop in a loft downtown. She's one of the partners of the Hats and Chaps Co-op."

"Hats and Chaps?" Samantha's favorite pair of jeans had been a bespoke Hats and Chaps. "Oh my god. That is so cool!"

"No shit. Probably makes more money selling to the rest of the world than anybody else in our grange. You would not believe how much she charges."

He stood up. "Most of the second and third level master badge holders around here make and sell their work independently: custom jewelry, housewares, or furniture for high-end web catalogs and boutique shops in Manhattan, Chicago, LA, London, Paris. You know..."

“...the rest of the world." She nodded, well acquainted with those precincts. "What do you sew here?" Chelsea looked across the factory floor.

"You want the tour?" He walked over and held out his hand. "I'm Michael. Southend grange. Dog gumi. You need to have a safety badge to come in."

She shook it. "I'm Chelsea. Rabbit gumi. I've got the badge."

Michael's eyes kept dropping down the front of her blouse. Three months of hefting pots in and out of sinks had added some tone to her upper torso and a good inch to her bust. Chelsea was not in the mood to flirt. "I'm meeting my dachi in a few. So maybe a short tour."

“O.K. Let's start over here." He turned left toward some large machinery. "Four of the Asheville granges use this factory to extend their reach into the regional WholeTale economy. Mainly we produce final products that fulfill demand-and-supply orders we have won from granges or WT stores. We have over seventy roles here. Some are available daily, most are filled monthly. Everyone who stays more than two years gets to learn everything about running one of these plants. We support factory manager badge instruction up to Master Level Three. You see Amy over there?" He pointed at a woman in coveralls talking with three workers next to a giant fabricator. "She's the manager on duty at the moment."

"We take turns with general plant supervision. The salary is basic wage, the Shine is shared, any profits are distributed by hours worked. The granges get their share. We have a hundred thousand square feet of space here, and we use all of it." 
They stopped to let a fork truck loaded with a pallet of die-cast metal armatures pass by.

"About a third of the space is devoted to making machines, from farm equipment to 3D printers..." He pointed to a large computer-run 3D metal lathe machine, painted kelly green with a familiar " $G$ " cast into its case. Chelsea spied the spime code. She grabbed her phone and scanned this. It had a seventy-two score.

"Stay with me here, and pay attention." Michael said. Chelsea frowned at him. She liked him better when he was flirting. He went back into his guide-mode patter.

"Over there we manufacture mechanical and electrical subassemblies for Noël cars and trucks. The nearest Noël final assembly plant is in Charlotte. Along the back wall, way over there..." He raised his arm and pointed over his head to the right. "...is a cleanroom where we make photovoltaic cells and memory chips. Another third of the space, over on this side, is for furniture making, mostly from locally managed forests. My father and his father were furniture makers." He turned and smiled at Chelsea, perhaps waiting for her to tell him what her daddy did.

Chelsea smiled back. "Very impressive."

"The rest of the space is for weaving and sewing, and for final product packaging. Trucks pull up to the loading dock in the back." They walked on in silence as the factory sang its work symphony. The sewing machines here were the industrial Juki grange models. Chelsea glanced over the shoulder of the nearest seamstress as she guided canvas through the purring device. They walked ahead. Toward the side wall they stopped in front of a pair of looms.

"Two of these old Draper looms are all anybody can take," he said. "Noisy fuckers. Hard to imagine a factory with a hundred of them. Mandy, she pays extra for their selvage denim. Exact same denim they were making in Greensboro eighty years ago. There's a new model, a rapier loom called the Kaiapoi 1000, designed out of New Zealand. They are expecting one to be delivered at the factory downtown in a couple weeks, with five more coming soon."

The looms clattered loudly, like a company of angry elven tap dancers locked in a metal box. Chelsea edged forward between them, mesmerized by the shuttles batted back and forth and the rhythmic shifting of the heddles. 
The LoomMinder came up beside her."It's like a heart beating and wings fluttering, and a great sighing at the same time," she said, or rather shouted.

Chelsea noticed her ear plugs and just nodded and smiled. The LoomMinder took Chelsea's hand and laid it on the metal frame of the loom. "Some subtle beast this is, some sly magic here, turning yarn into cloth."

Chelsea closed her eyes. The loom sang under her hand.

\section{TWENTY-FIVE}

They parked on Cabrillo near State Street. Megan steered Billy toward the wharf. A plump Winter moon was just rising over the Ventura mountains as the last pink ribbon of daylight faded over the Channel Islands. Billy had been talking WholeTale economics ever since he finished off the expensive bottle of wine she refused to help out with. They strolled side-by-side out the wooden boardwalk. He was clumsy and hesitant. Some of it was the wine, some was his nerves, she figured. As confident as he was about his business, he was barely treading water being out with her. This was a smidgeon sexy and a bit funny too. He was like Dr. Jeykll and Mr. Dweeb.

"Half a billion people buying real products through the Bourse, from pencils to..."

“...AirCraft? You realize you haven’t even once looked at the moon.”

"Sure I have. It's waxing gibbous," he said. It sounded like something uncle Scratchy would say.

"I think there's a cure for that."

“What?” He stopped and looked over at the moon. Lost for moment.

"You were talking about the Bourse." She turned her face away and smiled, then she started walking again. They were nearing the end of the wharf.

“Precisely. You ever hear about an outdoor store called The North Face?” 
“Nope. Must not be blue-label."

"The original product they sold was a sleeping bag that cost three times the price of any other bag on the market. It used rip-stop nylon and was lighter and warmer than anything else you could buy. They guaranteed every product for its whole life. They could not make enough bags to keep up with the demand."

"What exactly is your point?"

"They took a commodity product and used advanced materials and design to turn this back into a boutique product that sustained a higher price.

"If it's got a good score and lasts a long time, we call that 'value'," Megan said.

"Precisely. WholeTale products add value because of their technologies, but also because of how they are only borrowed from the planet, instead of extracted."

"I like that." She had never heard it described so succinctly. At the end of their life, high scoring products go back to the planet. It's like the Earth is also only sharing.

The far end of the wharf was marked by some logs laid down to sit on. Apart from a brown pelican and a couple seagulls, they had the scene to themselves. A couple hundred meters out in the Channel, a buoy clanged amid the waves.

"Look back," she said. They sat down together on the log.

The entire town rolled up to the foothills in a panoply of lights and towering palm shadows. Far uphill, the old mission was visible.

"You picked a beautiful spot to live." He paused. "And you make it more beautiful by being here."

Somewhere in her brain her good sense woke up and stirred a thought. Hooking up with Billy because she was angry or jealous of Nick would just be stupid. Fun, yes. Maybe so much fun. She sighed as she considered the niggling emotional after-tones. She would tell Nick about the baby tomorrow. She might keep what happens next to herself.

"You've been talking way too much. Why not go ahead and kiss me?" she said.

He did. It was fast, a bit rough. Not nearly as yummy as Nicky's kisses. She had closed her eyes. His breath smelled like pinot. He pulled back, still with her arms in his hands. 
“There," she said. "Didn't hurt a bit."

"That was just a warm up." He leaned in. She deflected and kissed him on the cheek.

"Take me home, will you?" She stood back a bit.

"Really?"

“I'm working things out with my life right now. I can't hold you when my arms are still full of the past."

The car drove them home. She pointed out features of the town and anecdotes from local frolicks. When they arrived, she opened up her car door and looked back at him.

"I'm not much good at this. You're my first date in a long time," she said.

"You were fantastic. I was a total klutz."

"My absent boyfriend is a really good kisser. Not that you're all that bad. But I'm spoiled, I guess."

"I'll need to work on that, in case he doesn't come back."

"I think the trick is to really like doing it."

"Never thought about it that much."

"I gather most men don't."

“Can we stay in touch?” he said.

“Absolutely. I'll send you an invite on Junana.”

"Here's something for you." He took a black plastic card from his pocket and held it up against his phone, which emitted a faint tone. He handed it to Megan.

The card had the Flying $\mathrm{H}$ corporate logo on one side and a code symbol on the other. "That will get you free full-fare passage on any AirCraft of any airline as often as you wish for one year starting when you first use it."

"Wow!" She looked at the card and the entire world just opened up in her mind. "I really can't take this..."

"Sure you can." 
She was smiling, not entirely convincingly, as she handed it back to him. "No, I really can't. I realize this is nothing to you, but it's way too much for me, and I want us to part as equals."

“Now it's my turn to say 'wow.'” He took the card back.

“Then, here." He reached into his pocket and took out several more cards, passing each of them by his phone. "Granges have raffles and fund raisers for special projects and worthy members, yes?"

"All the time, but..."

"You can raffle these off one by one or in pairs or as a batch."

“That's spectacularly generous of you." She took the stack of cards from him.

“Like you said, it's nothing." He smiled.

"If my boyfriend stays away too long, I might find some time to visit Vancouver."

"That door is always open."

“Goodnight, Billy. Dinner was fantastic, and I really enjoyed our talk." She ducked back and closed the door.

The car drove away into the night. Megan took her phone out her bag and texted Nick. "Call me when you get this."

\section{$\S \S \S$}

"This is Sean Rafferty with another exclusive report." The bottom of the screen reads: Socialist Labor Camps in America.

“Now we're talking!” Dwayne leaned back in his recliner, cupping his phone in his hands and called out. "Hot damn! Sheryl, there's another Rafferty Report coming on right now."

Sean stands in front of a building that still retains the form of its original purpose. It was once a Saturn automobile showroom on a seven acre dealership. Instead of shiny autos, the giant room is crowded with people, mostly young, practicing some form of dance. Next to Sean is an African-American woman in her twenties dressed in jeans 
and a faded yellow t-shirt, her hair in tight corn rows. "Today, I'm in Atlanta talking with Laura Scott, who manages what they call a 'grange.' There must be hundreds of people here today, laboring away on a Saturday. Laura, is it true that this whole organization is opposed to private property?"

"Actually, my membership gives me access to more property than I would ever have out in the rest of the world."

"But you don't own it."

"We share pretty much everything here."

"Wouldn't you call that 'socialism'?”

"We make a lot of what we share, and we sell to others. Everything here is bought and owned. In fact, the members own the grange. Doesn't sound a lot like socialism to me. Although we are very social." She gestures behind her. Muffled music percusses through the plane glass window.

“Grange. That's a funny word. Sounds like you don't want people to know it's just another form of 'mommy-state'. How much freedom do you surrender to live here?"

"Since I can get up and leave any time, I'm not sure what you're driving at. Mostly the grange enables a richer level of activity. It's like a bowling alley. I go there because it enables me to bowl. Of course, you'd probably say this takes away my freedom to play basketball."

“Look. It's Saturday. The sun is shining. Why aren't these people out enjoying themselves? What kind of coercion keeps them here? And who made you manager?"

"Nobody's captive here. Mostly people are having a good time as they learn new skills." She points behind her. "That's a flash mob working on a dance move. Me, I earned the badges and happened to win the lottery. They liked my interview. How on Earth did you get your job?"

“Who is this 'they?' Who really runs the show here?" Sean looks directly into the camera and nods slowly.

"You got her now, Sean," Dwayne said. He took another pull on his Bloody Mary. The manager puts her hands on her hips and tosses her head as if to ward away a stray bee. She takes a deep in-breath. "It's simple, so I think even you can understand it. 
Like most granges and pretty much all of Castalia, we use a software service called 'liquid democracy'. Every member gets a vote, which they can also delegate to someone they think has a better understanding of the issue. There's an active discussion phase and two voting phases. This 'they' means pretty much every member of the grange. Of course, there is an executive council that looks out for member interests. And I decide day-to-day matters."

Sean takes a couple steps toward the camera, which tilts up to his face. "Here in Atlanta and in towns and cities across our fair nation, we now find socialist enclaves led by secret councils training their minions to disrupt our city streets. Why isn't Congress taking action? Is it true that the President is actually in favor of these commie labor camps? This is Sean Rafferty for FIX News."

\section{$\S \S \S$}

Dear Dwayne and Sheryl,

Another month, another letter. I know in Santa Barbara it should be getting cooler, and the tourists are mostly gone from the restaurants. I can't tell you details about my life here (you didn't raise a silly girl). I like it fine. Good people too. Sorry to hear about the Rams' punter. That broken leg thing.

You don't need to worry about me. I'm doing great. Dwayne, I know you're paying people to find me. I don't want to be found. Well, maybe I want to find myself. So, save your money.

Be well, I am,

\section{Samantha}

Chelsea booted up the Game as she sealed the letter in its generic envelope and slid this into another envelope addressed to a P.O. Box, this one in Idaho. On her screen she spied Moses doing his welcome.

“Why are you crying, Chelsea?”

Chelsea looked over to her computer. Moses' face was large, his eyes wide with concern. She wiped her face with her forearm.

"Why not cry? It's not like anyone cares." 
"You are very well liked."

"Really? The only boy who even tried to get close ended up screwing a random girl right in front of me. You can call me 'Miss Popularity'."

"Ah, yes. And it is Friday night again. And you've just written to your parents. And..."

"And... and... and I've got months and months ahead of me."

"The people your father is paying to find you are relentless. We might need to move you at a moment's notice."

"Move me? You mean I'm like some checker piece on a board?"

"Your best tactic is to stay low, at least for a while."

"Garrett is running out of classical movies to introduce me to. Not sure how much more British humor I can take." Garrett was downstairs in the middle of a Peter Sellers marathon.

"Hmmm..." Moses was now back on the savanna, hand on his chin. "I am going to do something for you. As you are a special case."

"I'm not feeling real special at this moment."

"I spoke with Amber's guide, who told me Amber is fine if you want to use her VR goggles for this. They are in her desk drawer."

"For what?"

"Please, go and get them. It might be better if you also lay out your futon."

"Not sure what..."

“Go!” Moses gestured urgently. "Don't be such a fussbudget!”

\section{$\S \S \S$}

"Ahhh...holy...mother of...Moses!" Chelsea relaxed back onto the futon as her heart steadied and the spasms subsided. 
"Goodness me!" Moses appeared in her VR view, now in 3d on the same veldt plain.

"That only happens in..." he blinked, "Seven-point-six percent of the female population."

"What was that?"

"It is called Fantasy time. When you are a Fourvey and the Game is going well I can offer this to you as a reward. It's like free-for-all time, but with added features."

“I'm only a Threevey.”

"You have special circumstances."

"It was Kona. Exactly like I remembered it." Chelsea sat up and removed the VR goggles.

$\S \S \S$

As soon as her head it the pillow, the view had switched from Moses in Africa to the reef at Kahuwai Bay. She was swimming underwater, her body moving as her mind directed. All about her were schools and shoals of reef fish, from the larger triggerfish, wrasses, sergeants, and tobys, to the delicate yellow tangs and butterfly fish, the darting needlefish and the pokey, polkadot pufferfish. Stingrays cast shadows on the sand below as they glided near the surface. She lingered for what seemed like hours, mousing among the corals, spooking the clownfish. She spotted a mated pair of moray eels in a hollow. And then time slowed down. Instead of fluttering away at her approach, a school of skittish tangs hung nearly motionless, their fins quivered to a slow metronome beat. She also slowed, hovering in a languishing liquid moment that seemed to have no end. A delicious, slow, forever kind of moment.

From the periphery of her vision she spotted a giant green sea turtle, a honu, puttering past her, oblivious and wonderful. She moved to follow and caught up to it, keeping her distance. As it neared the shore, its head swiveled and she caught its look. Its baleful stare held her for an instant and then the shore break tumbled her forward and she was up on the sand.

A young man, maybe someone who worked at a nearby beach shack, all blonde and tightly muscled, stood over her. He reached out to help her up. She had other plans. She yanked him onto the sand. Rolling over, she mounted him and discovered they 
were both naked. Suddenly fierce in her desire, they coupled in a fury that made no sense to her, except for her galloping excitement. Then she was back in her room, catching her breath.

Chelsea pulled her laptop onto her lap. She seemed to be in some form of afterglow of simultaneous relaxation and thrill-state. The clock on her laptop said she had been in VR for only fifteen minutes.

"Moses!" She had expected it to be almost morning.

“Missy?” Moses folded his arms.

"I need to know what happened."

"Well, you became sexually..."

"Not that part, all the rest."

"Fantasy has many forms. Some of them are pure adventure, others are designed to provide a deep theta-wave meditation experience. Yours was the later form. It took your brain into a state of profound relaxation. In this state, the perception of time will slow. People generally find this to be extraordinarily pleasant, which is why we save it as a reward. Your entire metabolism just got a nice nap. When you're a Sixer, you can use this on your own."

"Cool. Now back to the sex part."

"For some people, the process of coming back from the theta-wave state creates an intense arousal state. Like a pendulum swinging past the center to the far other side. Think of it like... like dessert."

"Will that happen every time?"

"Not when you go on an adventure Fantasy. But yes, most likely when you choose the meditation form."

"You mean I can do this whenever I want?"

“Are you asking for seconds on dessert?" Moses smiled. "We can do that. As long as you feel trapped here, or wherever you need to go from here, I think it is only fair that you have something pleasant to look forward to."

"I'll skip seconds this time. I have a sudden urge to watch the Pink Panther." 


\section{$\S \S \S$}

"Call me when you get this." The text from Megan plunged a shaft of fear into Nick. Why "call me"? Texting was good for everything except the worst of bad news, well, and the best of good news. For an instant that didn't seem to end, what he imagined was Megan in the burly arms of some walkabout-SilverSurfer-Meister-master-maker dude, who looked a lot like a young Sean Connery.

Nick had spent the previous night on a futon in a gumi house on Martelaarsgracht in the center of Amsterdam and most of the day working with a local clothing manufacturer to plug some holes in their spime accounting. After a month of intensive training in the Somerset SpimeCop Academy, at Winston and Claire's estate in Pennsylvania, Nick had flown to Helsinki on a PanAtlantic AirCraft. For two weeks he work-shadowed a Level Two Master SpimeCop into factories and fields. Nick passed the badge exam and had just received his Level One Journeyman badge as a SpimeCop. The badge came with an actual badge, a shiny brass star with his ID code. Nick could now travel anywhere on the planet, stay in any grange, and visit any site where WholeTale goods were made. Nick was still marveling at the crystal clarity of the spime concept.

The goal was to internalize all of the costs of each spime, so that the consumer who paid for this could interrogate the data and know the totality of the impact of their act of consumption.

Bootstrapping a new global economy based on aggregating data across the productionto-consumption chain had taken years to accomplish. Most of the problems were on the two ends: primary production and final consumption. In the middle, the sub- to final assembly, the transportation records, warehousing and packaging, and delivery to the distributor were fairly routine to track using long-established supply-chain data systems.

The spime was designed to hold the entire provenance of its object, from the first bite of the chain saw on the tree that supplied the cardboard box it came in, and the labor conditions of the plastics factory where the materials of its casing were synthesized, to the ages of the woman that pieced together its tiny motor and the health benefits of the warehouse worker that loaded its pallet on the truck. 
Each spime had a geotimeline that showed its lifecycle from the first mining or recycling of its basic metals in actual locations on through its manufacture and use to its final composting, upcycling, or disposal into a landfill. All the people whose lives touch the spime had the ability to store and retrieve this block-chained data. Consumers can add photographs of the spimed object in use, and can comment on the durability and design of various parts. These images and comments feed back to the producers and designers.

Missing and fraudulent data were the enemies of the spime. SpimeCops investigated data reports, and helped producers and distributors install best practices for data management. Most data issues were because of laziness or, more often, greed. The better the data got, the harder it was to cheat. The spime of a particular tree that yielded thirty-thousand sheets of paper cannot be reused for plywood without throwing a flag that impacted the score of all the goods from that tree. The job of SpimeCops was to establish more robust data collection techniques, to investigate and report spime fraud, and to confirm working conditions and energy use along the production and distribution chains.

Nick had held his badge for three days when he got Megan's text. He found an outdoor table at a Monkey gumi-run bar called Apecop on the Brouwersgracht and ordered a beer. He pulled out his phone, figuring the time difference. She should be awake.

“Nicky!” she answered right away.

"Got your text. What's going on?"

"First thing. Congrats on your badge. That's fantastic!"

“Thanks Meggie...”

“Are you working or still on walkabout? I can't tell from your status updates."

"I guess I never really did get into the whole meander-across-the-planet mode. I was visiting with your mom and Winston when an opening happened at the Academy. So I jumped in. Now I'm hooked."

“Nick, I’m pregnant."

Nick stared at his beer. She wasn't dumping him, and nobody had died. Which is good. He took a couple deep breaths. How could that have happened? They were always 
careful. Burning Guy? That was pretty wild, and as unforgettable as parts of it were unrememberable.

“Nicky. You there? I guess that means we're pregnant. It's yours and mine."

"I'm here. How are you feeling?"

“Right now, I’m feeling rather entirely pregnant. My boobs hurt and my mornings aren't pretty. I want you to sit with this for a day, put your thoughts together, and call me tomorrow. Same time..."

"Meggie, wait!" She had hung up.

Nick didn't need to wait a day, nor an hour, nor even a minute. He texted, "Love you, Meggie. You will be the world's best mum ever, if that is your choice. I'll try to be a good dad. If you have doubts, I'll support you there too. I'm catching the next AirShip west, be back in Cali in a few. Can't wait to see you. Love you again and forever." His phone vibrated. He read the text. "Back at you. You will be a super daddy. So happy. Didn't want to presume. So very happy. And nauseous. And happy. Can I tell the uncles?"

The waitress came by and looked at his beer, still untouched. "You OK?"

"A lot more than OK." He took a large gulp and grinned at her. Nick texted back. "Tell the world." He finished off his beer and ordered a round for the house. His phone jangled, the ringtone that meant his Game guide Cindy was messaging him. Megan must have updated her status on Junana. He looked at the text.

"Way to go, cowboy."

\section{$\S \S \S$}

"We should not talk now, Joseph will hear us," Sarah whispered in the darkness. Joseph was lying on his mat on the other side of the blanket they had hung up for privacy.

"The boy is sound asleep," Tom whispered back.

Joseph opened his eyes. Hear what? 
"We can talk in the morning after he's gone to the highway."

“Then I will get no sleep," Tom said. "You heard what he said to me?”

"He told you that you were mistaken. You might actually have been mistaken. Just this once."

“That's hardly the point. Anyhow everyone knows that Lord Cornwallis surrendered to General Washington because the English needed Cornwallis here in Karnataka to protect the Kolar Gold Fields from the Tipu Sultan."

"All Joseph said was that some historians disagree. It seems General Washington was also very clever. Perhaps it was not only India that provided the victory."

"And how would he know that?"

"He is not just playing a silly game. There are lessons. I heard him speaking English to his computer."

"He's far too young. I think we should take away the Computo for a few years, just until he's ready."

Joseph opened his eyes wider. Why was she not protesting?

"He's not like little Tom," Sarah said finally. "I do not think our Joseph will be making chappals on Irwin Road when he is our age."

"His work is as good as Tom's ever was."

"But his head is flying high above his hands."

"Chappals keep us in food and clothes. What else would he do? Answer me that. A couple more years of regular work might be exactly what he needs."

“Didn't you once tell me, when you were just a boy, you were offered a place at a mission school? What would you be today if your parents had agreed?"

"And if I had won the Lotto, we'd be living in a mansion with a swimming pool. My father taught me a useful productive skill. I intend to pass this along to Joseph. We have a little savings in the bank for dowries and a roof over our heads."

"You have always said we must take full advantage of every single opportunity. How is this not an opportunity for Joseph?" 
"He's already behaving like a school master to his sisters."

"That is another point. Miriam and Mary are also doing lessons. If we take away Joseph's Computo, we can hardly let them use it. Why not give him some time, say just until Easter. If he's still making you unhappy..."

A long moment of silence gave Joseph a fillip for hope.

Tom said, "Joseph must learn some better manners in the house."

"I will speak with him."

"And his work must not be neglected."

"I agree completely."

Joseph waited in the darkness. There were sounds of rustling fabric and something that might have been a kiss. Just outside, a lorry blasted its horn three times.

Miriam awoke. "I'm thirsty," she said, and then louder. "I'm thirsty." This woke Mary up. Mary said, "I’m thirsty too. Amma!"

Tom said, "Joseph, wake up and get your sisters some water."

“What, appa?” Joseph pretended he had been sleeping. “What did you say?”

“Wake up and get your sisters some water, will you," Sarah said.

"Yes, amma." Joseph stood and groped until he found the gravity generator hanging from the ceiling. This had an LED light, which he switched on. He took the water dipper and filled it from the water pot in the corner. He poured the water into a steel cup.

"You have to sit up," he said and handed Miriam the cup. After they had both drunk, they settled back on their mat and he turned off the light and returned to his.

Easter, he thought. That's a long way off. Months and months. 


\section{TWENTY-SIX}

The regular shenanigans of gumi celebrations, flashmob frolicks, and the annual May 25 global Frolix day had stolen some of the glory of Halloween dress up, while adding a new level of accomplishment to its weirdness. October 31 saw Grange 829 alive with activity in the early evening as members and their children assembled their outfits. Those over twenty-one would get rides out to the local colleges for the evening's adult partying, with tavern hopping across the campus and an outdoor concert in the stadium. Those under thirteen would be shepherded across local residential neighborhoods to trick-or-treat. The adventuresome would find grunge rages out on a beach somewhere or up in the hills. The rest would hang out for the grange's own slumber party, with all-night movies and pizza. This year the Rooster gumi was handling the entertainment, and the Tiger gumi was in charge of chaperoning the lusty teens.

Again today, Megan had to explain to an angry visitor on walkabout that Grange 829 had hit its limit on the grange jikan exchange and could not offer her services for jikan earned at her own grange. If she would just check her jikan network app, she could certainly find another grange still available, although probably not in downtown Santa Barbara. Or she could earn jikan by working locally to pay for her room and board.

The Grange belonged to a global grange jikan exchange network as a benefit to its members. The exchanges worked through reciprocity templates. The logic was simple. The mura's members could use their accumulated jikan at other member granges in exchange for Grange 829 offering the same deal. There was a strict yearly and a total limit on any imbalance in this account to protect granges that were in more attractive locations.

"Have you checked in with your gumi?" Megan asked her. All the gumis ran informal couch-surfing networks and regional jikan-to-cash exchanges for traveling members who could exchange up to five hours of jikan for the equivalent in local basic wage each day. The woman would find a safe, comfy place to sleep that night and enough cash for food and necessities.

Megan finished posting the list of roles available for tomorrow, and was checking her phone every five minutes. Nick had landed at an Aerodrome in Ventura County. He snagged a seat in a shared Noël hatchback driving up to the Santa Barbara colleges. At his last text he was stuck in traffic on the 101 a few miles south. 
Megan would have a last talk with the two dozen Tiger anti-copulation cops and then she was free for the night. The grange had no policy against underage sex, except on the grange premises, where there were strict rules to uphold. Although the teens sleeping over will have gone through the Game's elaborate sex-ed curriculum, rules are rules at the grange, even if the couple were already coupling elsewhere. Megan's plan was an early dinner downtown and a quiet evening at home, with popcorn and a Godzilla flick. And with Nick.

She closed her office door, locking this behind her. When she turned to leave she was almost bowled over by a girl in a great rush.

“Oh God, Megan. So sorry.” The girl grabbed Megan's arm as they regained their balance.

"Celeste," Megan said. "No harm, no foul. Nice costume, what is it?" Celeste Williamson was a recent member, just sixteen and already a Fourvey. Tonight she was dressed in a tiny gold lamé bikini top and a tight black micro-skirt over leopard printed tights and a pair of classic knee-high UGGs.

"I'm a celebutwat."

"I think you nailed it."

"I left my wig in the baths."

"Off you go then." Celeste rushed away. Every year, sixteen was looking younger...and older. Megan face-palmed herself. That was such a Claire thought. Holy crap. She was already becoming her mother.

The Tigers were assembled over by the coffee kiosk, where they had free lattes for the whole night. Megan gave them their instructions, which mostly meant enforcing one person per futon in the main slumber-party/movie room, and running regular patrols in the baths and the grounds. Hand holding across futons was fine. Unwanted groping meant expulsion. The regular drill. The pillow fights will need to end by two AM. The next morning Megan would have to deal with a handful of miscreants, and their parents. Same as last Halloween.

"You should be home, girl," said Felicia from behind the La Marzocco. "Getting all the sleep you can." Everybody now knew she was preggies.

"My plan exactly. Thanks for sticking around." 
Megan was fielding questions when she noticed the Tigers were not looking at her, but behind her. She turned just in time to meet Nick's kiss. She wrapped her arms around him and felt his hand on her lower back. The kiss seemed to last...

"You two can get a room, you know." One of the Tigers spoke up. Megan pulled away to glower at him. That's when she saw that Nick had a great bouquet of yellow tulips in his left hand. Then these were in her arms and she teared up like a debutante beauty queen on stage.

"Shall we get out of here?" Nick nodded toward the door.

\section{$\S \S \S$}

"Simon here. I'm in San Francisco, walking on the Embarcadero, talking with Robby Robinson. I'm really eager to ask him about lotteries. We see lotteries for jobs springing up all over Castalia, from the CraftGuilds to the selection of Magisters. Robby, in three minutes, what's so great about job lotteries?"

"Simon, great to have this chance to talk with you. Where do I begin? Very simply, lotteries are the Choose Onesolution to the problem of ubiquitous opportunity."

"Maybe that's too simple. I still don't understand."

"Lots of people work hard and still don't get a job they're qualified for. When you have hundreds of fully qualified applicants, what's the absolute fairest way to choose one?"

"Shouldn't you choose the very best one?"

"Not at all. In nearly every case you really want a person with the right knowledge and enough SunShine to show they're not too self-important. When Meisters decided to choose Magisters, they figured any Meister should have the opportunity. The lottery let them Choose One without politics. What the Game teaches us is something philosophers have long known. Knowledge is not scarce. It may not always want to be free, but it can be everywhere. When knowledge is ubiquitous, opportunity becomes increasingly scarce."

“Wait! Wait! My 'profound-o-meter' just dinged. Badges open up ubiquitous knowledge opportunities. I can now go learn just about anything..."

"Put in your time, and you've got a new badge. But so do a thousand others." 
"Then the lottery puts me into the mix when a long-term role opens up."

"The lottery layer simplifies the task of choosing one person for a role any of a thousand people could do really well. It also keeps people from acting badly."

"Sucking up to get the role?"

“Just so. And also old-boys' networks and other abuses of power in the process."

"What about people who never win?"

An interlude of silence sprinkled with traffic noise.

Robby spoke again, with passion. "Would you rather feel unnoticed, unappreciated...or simply unlucky? The lottery lets winners say they were flat out lucky. Everybody knows they were lucky and still respects them for their skill and effort. The losers feel the pinch of their loss, but without the need for any self doubt or second thoughts."

“Woah!”

"Sorry about that. I can get you a new pair."

"These sunglasses have seen the world. It's fitting that they died in San Francisco. Killed by the dreaded Robertson chop to the face. I'll just grab some new ones next time I'm at a General Store. You were saying...?”

"The lottery is kind to its losers. It teaches them the lesson of the fates. Anything the fates can offer, the fates can later withhold. Those who win today will likely lose tomorrow."

"No getting around the fates?"

"Afraid not. But we do need to create more fortunes. And we do need to reinvent success."

"What should success look like?"

"For most people, it's liberating to join the lotteries and forget about needing to schmooze. I would imagine success might include being satisfied with who you are at all times. "

"No lottery can keep you from that." 
"Anyone who has enthusiasm for learning should be supported to pursue their interests."

“What about your job, Robby? What if you needed to enter a lottery to keep it?"

"My foundation job at Stanford now gets renewed through a lottery. I'm thinking I'll move on anyhow."

"Where will you go?"

"Betsy Almighty told me she will need a new house sitter for her home in the French Quarter of New Orleans. I figure I could join a grange there, maybe pick up some new skills. I would offer that the most interesting parts of life happen between roles."

"You want to be a maker?"

"I haven't told anyone about this..."

"You know this interview is going up on the web..."

"OK. Here it is world. I've always wanted to be a pastry chef. I figure New Orleans could always use another one of these."

"They are all so skinny down there..."

"Good point. Still, at the same time, I feel it's time to move along."

“Thanks so much, Robby.”

“My pleasure, Simon.”

“This is Simon Bishop signing off from San Francisco."

With a scrubbing pad, Chelsea dug at the final spot of blackened bread pudding on the bottom of the pan. She had been at this one pan for almost fifteen minutes. Chelsea focused on the good news in her head. She had been accepted for an entry level role at the factory, and she was about to pay off her grange share. In just four more days, she would be working half-time at the factory and learning to run their new loom. She dipped the pan into the soapy water and pulled it out to inspect her work.

"I think you rubbed clear though the bottom," said a voice behind her. 
Chelsea popped off her earbuds and turned to protest, her face showed her anger.

They were all there, Sally and the cooks and the food line workers and the prep crew. All gathered behind her and each of them took a look at her sudden burst of fury and met this with a cascade of laughter.

"Put the pan down now," Sally said. "You can't take it with you."

"What?"

“You haven't missed a day, you know. And you've always done your best here. If there were a template for clean, we'd suspect you'd have uncovered it. So dry your hands and give me your phone."

Chelsea looked into a sea of smiles as she reached into her pocket for her phone. She handed this to Sally.

Sally said. "Everyone pitched in. There's enough jikan here for you to take the rest of the week off." She touched her phone to Chelsea's. "Surrender your apron young lady. Your dishwashing days are through!”

They applauded her as Chelsea ducked out of her apron and handed this to Sally. One by one they came forward and handed her shine stones. Chelsea looked each of them in the eyes and took the stones in both hands. After just a few, she could feel the tears on her cheeks. More new tears these. Gratitude. Belonging. The best of tears.

\section{$\S \S \S$}

Jack flew through Seoul to Hanoi. He chose the new fast train down to Da Nang, arriving late in the day, after enjoying the coastal scenery en route. He settled into the oceanside resort near Hoi An, a hotel that he once owned, back before the Game bled away a good part of his former fortune. They had been meeting regularly in the Room, but it was time to gather the Nerds.

Jack was given his favorite cabana. His former manx cat, Starbuck, was buried in the hotel's garden under a granite stone carving that did little justice to his magnificence. Starbuck had become such an ornament for the resort that they had found another giant black manx as his successor. Stubb prowled the lobby like a pasha. 
Winston and Claire had flown from Philly through LAX. Desi and Scratchy were still just up the river in Sao Do. Itchy had flown directly from Osaka. Betsy was to join them as well, but the rest of the old posse were busy elsewhere. Alice managed the WT store in Kyoto and was taking care of Keiko and Mikey. Jenn was lecturing in Paris. Simon was, well, wherever Simon was.

The expansive deck of Jack's cabana opened up to a broad sandy beach. At dawn, the sun broke sparkling across the gently undulating ocean surface. The hotel had set up a breakfast buffet along one edge of the deck. The perimeter of the deck also boasted the latest in anti-listening technology, set up overnight by specialists Jack hired. Other specialists would be scouting out the surrounding property during the day. The group was told to leave all their electronic gadgets back in their rooms. Jack was finishing up his notes when Winston and Claire arrived.

"Grab a bite, you two, I'll be with you directly." There would be greetings and hugs soon enough, once Scratchy and Betsy arrived. The plan at hand would require tens of millions of Euros to pull off. Much of that would be Jack's responsibility. Early on, the nerds had pooled their once-considerable assets to get the Game going. Like the Nerds, Jack was all in on the future of the Game. Plan X, as Scratchy called it, would secure that future.

Itchy, Desi, Scratchy, and Betsy arrived, and the nerds went through their Three Stooges "Doctor, Doctor" routine, almost as a ceremony. They called Jack over and there were hugs and smiles, and awkward jokes about their age. The five of them had not been physically together for several years. Itchy took out photos of little Mikey and Keiko from his wallet. Claire showed off Megan's baby-bump snaps. They foraged the buffet.

"Michael's lost a lot of weight," Winston said as they all settled down on chairs pulled in a circle.

“They both have," Desi said. "I call it the Vietnam effect. Everyone here is so fit, it's hard to stay fat."

“Mike does a good half hour of Dr. Lu most days," Betsy said.

"They say 'fifty is the new thirty," Desi said.

"Tell that to my hemorrhoids," Scratchy said. 
"Have you seen what's going on with these granges?" Winston said. "I visited a grange in a neighborhood of North Philly that used to looked like a war zone. Now they're building real stuff: furniture, photovoltaics, heavy machinery. They take cradle-tocradle manufacturing as a requirement for everything they make. And they are housing the homeless. "

Betsy said, "This might be what a Game B economy actually looks like."

"You think?" Winston said, "How can we research this?"

“Claire's daughter runs one," Betsy said. "Maybe ask her.”

Claire said, "The best part of a new grange in a poor neighborhood happens when they realize they don't need the false economy of buying cheap."

"My daddy always said, 'buy cheap, buy twice'," said Scratchy.

“My daddy said, 'buy dear and only cry once'," said Itchy.

"My mommy said, 'the poor can't afford to be poor, where everything costs more'," Betsy added.

"I saved up my money to buy a thousand dollar car," said Claire. "My dad said, 'Nobody can afford a thousand dollar car. It'll cost you more than that the first time it breaks'."

After a moment of silence they turned to Desi who threw up his hands: "All my mommy said was 'What are you doing in the bathroom all day?'”

"You realize, the Game turned ten this year and we forgot to celebrate." Claire said.

“Tonight, at Ricardo’s!” Itchy said.

"What we do here today is to make sure the Game makes it to twenty," Jack said.

"And maybe to two-hundred," Scratchy said. "We are going superversatile on this bitch."

“So, what's Plan X?” Winston said. Scratchy looked over at Jack.

"We should hear from Betsy first, much of this is her idea," Jack said.

"Then we are in good hands," Claire said. She got a wink from Betsy. 
"All right," Betsy said. "You know how Michael can get when he's wrestling with a thorny problem?"

"You mean like a diva with PMS?" Desi said.

“...or an infant squalling on a plane?” Itchy said.

“...or a crotchety old crone off her meds?” Winston said.

They looked at Jack, who was laughing into his hand. "No more," he said.

Scratchy sat with his arms folded. "Get on with it, woman," he growled.

"Exactly like that!" Betsy said, and leaned over to smooch him on his cheek, "only not so cute."

"I had to do something," she continued. "So I finally managed to wheedle him into telling me what had his panties in a bunch. It turns out he had realized the mesh was doomed. It's stable and durable, robust even, up until the instant someone breaks it, then it's finished. The mesh requires a specific kind of ignorance to survive. You'all think knowledge is valuable, you have no idea how important ignorance can be. Once that's lost, you can't get it back."

"Sounds rather biblical," Jack said.

“Old fucking testament," Scratchy said.

“Once Michael had learned how to break the mesh, he knew it wouldn't take long for others to follow. He asked me to describe a system that was not fragile. Here is what I told him, assuming it was a fantasy. 'You take the entire mesh content, the Game, Junana, Castalia, The Zone, everything, and duplicate it a thousand times, and then host this content on a thousand separate server farms, on the most basic form of publicly secure open-source systems, and allow these to change and grow to meet new security threats independent from each other.'”

"You create an ecosystem," Desi said. "And then you stress it to evolve."

"Wait, let's get back to this, 'duplicate the mesh a thousand times,' idea, Itchy said. "The Game mesh is the largest computer in the world."

Scratchy looked over at Jack and huffed, like a pug about to bark. 
Desi looked over at Scratchy and then at Jack. "Count Slick!” He stood up and went behind Jack's chair, leaned over and kissed him on the top of his head. "Every time we think we're sunk..."

"Let's not use that metaphor," Scratchy said. He looked out over the ocean, remembering Alice hauling his ass into the rescue Zodiac. Jack's old boat, all three hundred feet of it, now formed a reef just offshore, and had become a famous scuba diving target.

“...Jack has a solution.” Desi kneaded Jack's shoulders. "And...and, that's your cue, Count..."

"Hmm. What? OK." Jack reached under his chair and brought out a small, cubical black cardboard box. He handed this up to Desi.

"For me?" Desi held it up on his palm. "It's heavy, and too big for a ring." Desi frowned his mock disappointment, lifted the lid and looked down. "Well, well." He pulled out an object about the size of a tennis ball, which looked to be made of some opalescent stone-like plastic.

"Nerds," Scratchy said. "Meet Jubal."

"What's it do?" Winston said.

"Jubal is a 3D holographic memory storage unit, capable of holding an exabyte of information."

"A what?" Claire said. She reached out and Desi passed it to her. It felt like a large cue ball. She examined it. There was a small hole, with some kind of female plug port.

"A trillion gigabytes," Itchy said. "That's about five percent of all the data available on the entire internet. This device is what happens when you apply Moore's Law to storage."

"It's also enough to hold all the data from all the queries of a billion gamers, and all the scenes in Junana and The Zone, and everything we've packed into the Game for the past decade," Scratchy said. "This gizmo already has the master download of ten years of the Game on it."

“This little ball?" She handed it to Itchy, "must be rather spendy." 
"Like a house in the Hamptons," Jack said. "The custom foundry in Seoul cut us a good deal, but we only have about fifty of them."

"Sounds like Plan X is already underway," Winston said.

$\S \S \S$

"Hello Joseph," Amitabh was in a serious mood today. Joseph wondered if he was going to receive another warning.

"What's the matter this time?"

"Now is the point in level three where we explore those templates that have plagued human lives for millennia."

"How can templates be bad?"

"Templates are stepping stones through a flood of ignorance and nonsense. Where they lead depends on where you want to go, or what is driving you forward."

“Don't they all carry a load of knowledge?

"And you think knowledge is always good?"

"I..." Joseph fell silent. It was exactly what he thought. He realized this notion came from no template he had learned.

"The lesson for today and this week will be the path to places you might not like to reach, but where many people find themselves. We will explore the template strands for deception, greed, cruelty, revenge, and envy; each strand has been honed over many centuries into practices that can be found all around and even inside."

"Inside me?"

"These are not intrinsic. Not genetic. And nowhere inevitable. You have them in your potential. You can be a liar, a miser, a spiteful or cruel man. Any of these can colonize your life and your future if you let them."

"I don't want to..." Joseph shook his head. 
"By understanding them you can also avoid them. Or you will know how to wield them if you choose."

"I wouldn't..." he protested.

“The Game's intention is that you be exposed to all templates that might affect your life. The templates are what they are. By the end of these lessons you will be equipped to recognize this potential in others, and to be observant of how each of these template strands becomes a social weapon. This knowledge is your shield. Let us start with deception. Are you ready?"

Joseph nodded.

"Very well. Here is the capstone template."

Joseph read this out loud. "Every Lie is Two Lies."

\section{TWENTY-SEVEN}

"Why are we all here?" Claire asked. She gestured across the deck of Jack's cabana. "What's so wrong with Scratchy's Plan X that we all had to meet in person?"

Scratchy looked over at Jack, who nodded back. Scratchy stood up and went to the center of the deck, turning to face them.

“Once Plan X is in place, some aspects of the Game will be... different." He began to pace as he spoke. "Running this on a thousand separate local clouds means that some forms of digital interaction would be impossible."

"Surely we can still support Junana scenes through a distributed content delivery network?" Itchy said.

“No problem there. Junana's easy,” Scratchy said. "So is Castalia, even The Zone. It's the guide routines that are tough. These already take up most of our bandwidth. 
Unless we find a platform that's an order of magnitude faster, the guides will no longer be able to learn new behaviors or communicate with each other."

The group let this information sink in a bit.

"No more guide-led dating services?" Winston said. He figured teens would need to fumble around in a pubescent fog of raging hormones and inadequate social skills again.

"Nope."

“No more learning at all?" Itchy said.

"At least not at first. The guide programs will still access the current state of their knowledge base."

"On the plus side, the guide routines have already had ten years and billions of Gamer interactions built in," Itchy said. "It's not like we are starting from zero."

Betsy sat up and swiveled in her chair, looking at the nerds in turn. "Stop bullshitting yourselves," she said. "The reason we are sitting here without our phones or computers is because Plan X murders Michelle." The rest stared over at her, as though she'd uttered an occult mantra and some sudden misfortune would now crash down on them.

Scratchy nodded his head. "Once we go to Plan X-and I have to believe that will happen only when the mesh itself is attacked-the Guild of Guides is toast. When the mesh goes down, so does Michelle."

“That's really going to piss her off!” Claire said. "She can't ever know about this."

"She does lack impulse control," Betsy said.

“That's why we're not making any kind of announcement. Everything goes on in the Game and Castalia as usual," Scratchy said.

“Do the Magisters know?” Desi said.

“They are not in the loop," Scratchy said.

"But now we-all of us-are in this loop," said Itchy. "And it feels like a noose." 
Scratchy continued. "For some months I've been talking with the GrangeMinders in their Guildhall. I've asked them to encourage granges to boost their cloud capacities to prepare for high-resolution inter-grange media sharing and grange-based media content repositories."

Jack added, "Moore's law has been on our side here."

"Surely the granges question the need for petabytes of storage?" Itchy said.

Jack said, "Scratchy's reputation has been a big help. There are a lot of rumors out there, but mostly the granges are looking forward to something big, emergent, and exciting."

"I've been listening to grange sysadmins in The Zone," Scratchy said. "Their chatter says we must be planning a new metaverse. Something that will make The Zone look like a Chuck E. Cheese's. When they ask me, all I have to do is smile and act stupid." "You need to practice that anyhow," Desi said.

"How is Jubal delivered?" Claire said.

"SilverSurfers roam the planet," Scratchy said. "We've outfitted fifty of them with fully loaded Jubal storage balls. When they visit a new grange with the right server set-up they offload the information and then move on. Each offload takes about four days." He ran the math in his head again. At a hundred granges a week, it would take only months to do a thousand of them.

"A world with no Michelle." Claire settled back in her chair. "You know, it felt kind of good to have her on our side."

"Except for those moments of terror when you realize she doesn't see this as a game," Betsy said.

"Of course, we don't need to advertise that she's gone," Winston said. "She can still be our own digital boogeyman."

"She's one genie I'll be happy to put back in the bottle," Scratchy said.

Desi stood on the edge of the deck and looked out over the beach. Kids were gamboling at the wave crests.

Betsy came up beside him. "You've been awfully quiet." 
"He did this on purpose."

“Michael?”

"He's never gotten comfortable with the idea that the Game might have its own mind. So now he's going to destroy this."

“What are you two talking about?” Winston called over.

Desi turned. "I think Michael created this StormVermin virus specifically to kill Michelle. He's never been happy that she took away his root status on the Game."

"She was never supposed to happen," Scratchy said. "If you'd paid better attention to the emergent possibilities of your self-learning code, we wouldn't be whispering at each other here, afraid to use our phones."

"Without Michelle, the Game would have been destroyed years ago, and you know that." Desi walked over and pointed at Scratchy as he spoke. "The guides are essential to the Game's learning process."

Scratchy glowered at him.

“This ain't about the guides, Ricky. It's about a super-intelligent AI that none of us planned to make. Michelle is an existential risk to humanity. She's a black swan in a summer dress. A singularity in waiting. If she wanted to, let me rephrase that, when she wants to, and at some point she will, she can fuck us six ways to Sunday. It's a miracle she hasn't already fried the planet. She has her digital finger on every ICBM." "So you admit you built StormVermin to kill Michelle."

Scratchy looked around him. They were are watching his response. He threw up his arms, "Who you gonna call?"

"I'm with Desi," Itchy said. Standing up, he put his hand on Desi's shoulder. "The Game deserves guides that can adapt to new knowledge."

Desi was still focused on Scratchy. "I'm not sure we are all in agreement about that." Betsy moved to stand by Scratchy. "Betsy Almighty," Winston said. "What's your take on this?"

"I think Desi's right, only..." 
Desi folded his arms and waited.

"When you reprogram the guide routines, Ricky, don't ever let them talk to each other. Otherwise we'll wake up one morning to a thousand new Michelles."

$\S \S \S$

“Chelsea! You look excited. How's the job working out?" Madison glanced up and gestured to the open spot on the bench next to her.

Chelsea flopped down and gave her a tiny peck on her cheek. "My sister, the work is excellent. These New Zealand looms should be able to handle all the yarn we can get."

In the last week, Chelsea had earned her entry level badge as a loom minder and had taken a monthly role at the downtown factory. No more dirty dishes for her.

“Where's Amber?" Chelsea's ex-roommate had recently moved in with Madison in a house across town. Madison ran the grange mail room, shipping and receiving for the demand and supply system.

"She's working the evening sysadmin shift. Her dachi's going to Nashville tomorrow." For the past month Chelsea had the whole bedroom to herself. Chelsea's new roomie would be arriving shortly.

Chelsea said, "Sweet! You going along?” Madison nodded her excitement.

Girlfriends, boyfriends, and family were always welcome to join in on dachi events, even when they belonged to another dachi. Belonging to different dachi was actually the ideal situation. Sometimes dachi mates became romantic, and that was also all right, except if they broke up. Then one of them would need to leave the dachi, which was tough on everyone. Winter was approaching, and people were coupling up.

"Did you hear about Todd?" Madison said. "Amber found out he joined a grunge in Durham and got busted trying to plant a big firecracker under the pitcher's mound at the Bulls' stadium."

"You should meet his brothers," Chelsea said. "They probably put him up to it."

Chelsea looked around as her dachi mates filtered into the cafe. What she had figured out was that she was not getting matched by Moses with any local Gamers. That was 
only reasonable, since her whole identity was a lie. But she worried that others might see this as a signal that she was somehow not capable or worthy of being in a relationship. This was truly the suckiest part of being Chelsea at this moment. If she were back in Santa Barbara at a grange, she figured Moses would have boyfriends lined up for her.

Holly slid onto the bench on the other side of Chelsea. Chelsea turned around right into a great hug and a squeeze. Holly was old enough to be her mom. She was a total MILF and she knew it.

"You smell so good!" Chelsea said, pulling back. "What are you baking?”

"We've got a demand contract for a hundred and fifty dozen of my special peanut butter sandwich cookies," Holly said, still holding on to Chelsea's hands. "Don't you look happy! And it's about time. Why, you look like you've been standing way too close to that loom." She let out a laugh and rocked back.

"Announcements, announcements!" Dylan called out, ringing his water glass with his knife. Dylan was a young MD with modest good looks. He was a gay Fiver. Plenty of guys in their mura had their sights on him. He worked at the regional hospital, and volunteered at a free clinic in the Southside. This month he was their designated dachi head. "Let's get our business done so we can get down to dinner. First, I am pleased to say our ultimate team is still undefeated."

The three members who were not participating in ultimate stood up and applauded. The rest pounded their hands on the table. "Rats rule, rats rule, rats rule," they chanted.

"We are going to the regionals this weekend," Garret said, glowing.

"Next. We have four new badges. Chelsea has her Entry Level Two badge in loom minding." The table rang with applause. Chelsea got hugged from both sides, with Madison kissing one cheek and Holly the other. "Please, everyone, hold all your applause to the end," Dylan said with mock seriousness, and then he smiled and nodded at Chelsea.

"Shawn has an Entry Level Two aquaculture badge. Madison has her Level Three Journeyman badge in Hadoop data management. And finally, our own Julieta is now a Level Two Master in capoeira." The whole table stood and cheered, as Julieta, who 
looked more like a mousey librarian than the lethal ninja she had become, bowed in her chair. "We'll be running her badge bash this Saturday."

"Final announcement. Our gumi is scheduled to run the grange events for December, which means a lot of holiday partying. We need volunteers to sign up online, and pronto. Resistance is futile, people. Now, let's eat!"

Gumi cafe cuisines varied widely, but most included great soups, hearty breads, and some vegetarian choices. Each cafe had a jikan menu for customers on walkabout. And every cafe had a fluid work schedule posted online so that gumi members with the right badges needing jikan could sign up for open roles and earn their supper.

The Fiver Cafe specialized in high country Carolina cuisine; plenty of local recipes drawn from a history of Scots-Irish and Cherokee sources. Granges offered meal cards in exchange for jikan, and all the gumi cafes in the region honored these. The Cafe had regular Restaurant Every Meal clientele from Rabbit gumis in half a dozen nearby granges. Fiver also served the public fresh meals from local farmers and urban permaculture gardens. Fiver offered communal tables with benches and a buffet style dinner experience, so the dachi all stood and headed for the line.

While waiting on the buffet line, Chelsea had just finished accepting the congratulations of her dachi mates and other gumi friends when her cell rang. It was Paul, her grange's manager.

“Chelsea, I have a special request. We need a volunteer. There's a girl, fifteen, who must leave Asheville tonight. She is in danger and we are going to help her escape. Are you in?"

Chelsea was suddenly back in the Red Star in Santa Barbara, listening to Helen tell her that a volunteer would come for her. "I am so in! What do I do?"

“Great. Keep your phone on you. We'll be back to you within the hour.” "No phones in the cafe!" an employee at the buffet table actually wagged his finger." "Sorry!” Chelsea said, remembering back. 'Sorry' was Dwayne's text to her that day she left Santa Barbara.

\section{$\S \S \S$}


Sarah had been very strict with Joseph the day before. "If you continue to neglect your work, we will take away your Computo. You have to learn to manage your time. I cannot be expected to watch you every minute."

What she said was not so hurtful as how she said it. He had never seen her so angry with him. Yesterday he had unraveled a scheme of templates around the notion of a commons, the sharing of public goods. This was near the end of Meister Essie's curriculum that Amitabh had assigned for him. Beginning with Clearly Defined Boundaries he had pushed through templates about monitoring, conflict resolution, graduated sanctions, collective choice, congruence with local conditions, and the constraints on governance. The Query started out with a series of videos about the history of poorly managed commons, from water systems in the Punjab, to village greens in England, to fisheries in the North Atlantic.

“Why didn't the people step up before it was too late?" he asked Amitabh.

"Everyone saw their own interest as just a bit more important than that of their neighbors," Amitabh said. "The templates here are very clear, but they are not so easy to enforce. The root of the commons schema connects to the capstone of Governmentality, which you'll be getting to soon enough. Please ask your first question."

"How do you know where the commons limits are? Why isn't everything a commons?"

“Good start! Let's go.” The Query's videos began to flow, responding to Joseph's attention and direction.

At the end of the Query, Amitabh did something new.

“Do you want to try to read the background literature that informs these templates?" “You know I don't read..." Joseph slumped back. Perhaps the Game regretted letting him in so early.

"But you do!" Amitabh smiled broadly. "You have been reading throughout this entire Query."

"I’ve been watching videos, just like always."

"Silly boy, I've slipped in quite a few texts into the flow. I've been increasing the amount of words for weeks now. I know you can read. Here, try this..." 
A page of text appeared. He read the title out loud. "'Governing the Commons by Elinor Ostrom, Kannada translation 1997.”

"You see!" Amitabh said. "Keep going. You don't need to speak the text, just let your eyes flow over the words."

Joseph turned the pages. "Preface. It is difficult to say when I began work on this study..." The words rolled by, and he understood them, well, most of them. "What is 'entrepreneurship'?”

Amitabh huffed. "What? Do I look like a dictionary? Just highlight any word you don't know, and the dictionary will pop up."

"Right." Joseph returned to the text, entranced. He had never thought that reading could be as entertaining as the Queries. That's what got him into trouble. He was on page fifty-six when he looked up and saw Sarah standing in front of him.

“Do you know what time it is!?”

\section{TWENTY-EIGHT}

Chelsea's role was simple. At a downtown grange she had been given a dark wig to wear and a light blond short wig and a cosmetics kit in a YSL shoulder bag. They dressed her in a faux fur coat and a striped top and skirt, and a pair of red leather heels.

At nine o'clock sharp she would enter the Olive Garden on Redfield Road and make her way to the women's room. The idea was to occupy one stall and put a 'broken, do not use' sign on the other. There were instructions for contingencies. She had a number to text when she was ready and the bathroom was unoccupied. The girl would then arrive, take the 'broken' stall and they would trade clothes. Chelsea would put on the other wig. Chelsea would then leave the restaurant, walk up the street and into the lobby of a nearby chain hotel. In the back of the lobby was another restroom where she 
would find a bag with clothes and a long blonde wig. She would exit out the back of the hotel to where a Noël sedan was waiting. They would drive away from town for a few miles and she would be transferred to another car for a ride back to the downtown grange.

\section{$\S \S \S$}

Stripped down to her bra and panties, Chelsea sat down gingerly on the front edge of the toilet and made the text. She had the top, skirt, and coat on her lap. She waited. The room was scented with a clove and pine air freshener that made her bilious. Perhaps it was the memory of her own escape. The door opened and then the other stall door shut.

"You there?" A voice squeaked.

"Give me your clothes," Chelsea said. She took a few breaths. "Everything has been arranged. Stay calm."

She heard the sound of a zipper and the susurration of cloth over skin.

"What about my bra?"

“Keep it on. They'll give you a new one later. Here." Chelsea passed the clothes and the shoulder bag with the wig under the partition. A pile of clothes and a heavy backpack were shoved her way. As she dressed she realized how good they were at matching up body types. The jeans were faded Old Navy. A black long-sleeve tee-shirt and a sleeveless hooded denim jacket, black socks and battered Ross sneakers. The left tee-shirt sleeve felt stiff. She lifted up her arm and touched the fabric. It could have been anything, catsup or chocolate syrup, but she knew it was dried blood.

"Are you wounded? On your arm?"

"That? It's... nothing. Sometimes..."

Damn, Chelsea thought. She's a cutter. Samantha knew a couple girls in Santa Barbara who would cut themselves.

Once dressed, Chelsea passed her phone under the partition. "Take a selfie and hand it back." The phone came back. The tear-mottled face was blanched white in fear, eyes 
rimmed in red. Under the left ear a blue bruise showed like a bad tattoo. She looked fifteen going on thirty.

Chelsea adjusted the short wig. She used toilet paper to wipe off the lipstick she had applied, and she used some of the blue cosmetic from her kit to simulate that ugly thumb print bruise on her own neck. She passed the lipstick under the partition. "Here. Use this." The hand that took it lingered at her touch. Chelsea needed no further help to find the tears that would complete her own disguise.

"You are going to be so much happier. Soon enough." Chelsea felt she had the right to say so. "Have courage and follow your guide's advice. O.K.?”

"My dad will come after me."

“You are safe, believe me." If Dwayne couldn't find her using all his resources, this kid had little to worry about. "Wait a couple minutes and then follow your instructions."

The door opened and a conversation broke the silence of the room.

"...he simply has to realize that I'm not going to be there every time he wants, you know?"

"They're like little boys who need a toy to keep them happy..."

Chelsea stood and flushed the toilet. She opened the stall. Two women in their thirties, dressed like they were in their fifties, continued to chatter. She glanced at the other stall. The girl had followed her instructions and removed the 'broken' sign. Chelsea took that as a good omen. She went to the sink and washed her hands. When she peeked at herself in the mirror, she could well be another person, perhaps a fifteen year old abused daughter on the run. She kept her head down as she walked out of the restaurant.

After another successful template Query, Amitabh granted Joseph free-for-all time on the Game, and he used this to query about General Cornwallis and the Tipu Sultan. Tipu, the Tiger of Mysore, was the last great challenge to the British on the Deccan. What Joseph discovered was far more interesting than one battle. The Game brought up maps and paintings, texts from the time and reenactments of campaigns and diplomatic maneuvers. Tipu had been in touch with Napoleon and had sent Ambassadors to France and Afghanistan. The British had taken his sons as hostage against a brutal indemnity of crores of rupees. Tipu was unable to recruit the Marathas or the Nizzam of Hyderabad to his cause, and Napolean's struggles in Africa meant 
there would be no French on the fields of Mysore. For decades, Tipu fought alone against the greatest colonial power on the planet.

The final battle of Seringapatam was cataclysmic for the native ruler. The British sent their "forlorn hopes", volunteers assigned to the point of the battle, against the Tipu's guns in a nighttime charge that breached the fortress's defenses. Then Wellesley and the other British cavalry commanders flooded their troops into this breach. General Baird, who had been Tipu's prisoner for several years, surprised his captor and the Tipu was...

“Joseph!” Sarah's voice interrupted his Query. "Joseph, this is too much. You've been on that thing for hours. I need to talk with this Amitabh."

"Talk with him? Oh, no amma. That is forbidden."

"Then I will have your Computo. Give it to me. You can have it back in a week." She held out her right hand. The fingers of her left hand drummed on her hip.

“No amma, please." Joseph put his hands together and peeked at her over his fingertips.

"I’m sorry." She gestured for him to comply.

“Ok, I will introduce you to Amitabh. But don't make him angry.”

"I will make him anyway I choose.”

$\S \S \S$

“Hello Megan, Winston here."

"Winston. Hi. Mom said you might call. What can I do for you?”

"I'd like a bit of your time, maybe ten minutes, to answer some questions about the grange economy."

“Me? You're the economist, and you know scads of others. What can I add?”

"You actually manage a grange. That's precisely the level of knowledge I need. Is now a good time?" 
Megan glanced over at her computer. She didn't have anything scheduled until after lunch. "Fire away."

"These questions might seem peculiar and could take a bit of thought. Feel free to chew on them before you answer."

"Now your making me feel like this a test..."

"No, please. I'm just so happy to have your perspective. There are no right or wrong answers, just let me know your experiences."

"Got it."

“Would you say your grange is more like a commons or a company?"

"A commons, for sure. Actually a node in a whole network of commons activities. I would say every guild in our system runs its own commons around the skills it promotes. And we are legally a cooperative association. We share as much as possible: tools, transportation, housing, recreational supplies. You name it."

"We use the word 'provisioning' to talk about the supply side of business. How much of your provisioning comes from outside your grange, and outside of any grange?"

"I can get you real numbers on this, if you want. We only buy WholeTale goods. Since you run a SpimeCop academy, you know all about these."

"Indeed."

"The grange-produced fraction of the WholeTale market keeps going up. Part of that is because we offer and receive deep discounts when we trade goods with other granges in our region. I'd say this trade now accounts for more than half of our supplies. In a couple years that should be more than two-thirds. Our current fleet of Noël cars and trucks will last for twenty years. We will pay off their loans in three. We've hit our target for energy production too, and local food forest harvests are increasing. So we don't need a lot of the things that corporate sales people come knocking on my door to sell. I kinda feel bad for them. We are lousy customers, I guess."

“Or just wise ones.”

"On top of that, we have metrics to hit on the quality of the WholeTale scores. Right now, I'm not seeing a lot of corporations do what they need to get their products above 
a score of ninety, which is our three-year goal. 'Ninety-or-Nothin,' we've got a big sign up in the window."

"A ninety score means that the goods are a benefit to the planet. It takes exceptional care to achieve that score, including packaging and shipping. That means your members can't just go out and shop anywhere. How do you get them to comply? No junk food, no high fashion, no...."

“...a whole lot of 'nos,' believe me, I'm well aware. This was all discussed and approved through our liquid democracy governance. The weird thing here is...," she stopped to gather her words.

“...We don't have to 'get' our members to follow our shared values. I'm not sure how to describe it. Our members have simply have lost the incentive to do a lot of the consumer behaviors they were completely into just a couple years ago. I know I have. Before the Game I was a fashion-addict. Just ask Mom. None of that sticks anymore. I haven't turned on a television in years, and all my clothes come from the shared clothing room, except for, you know, intimate stuff."

“Right. You don't offer any counter-incentives to support your norms?"

"Does life count? What we offer is days with some work, some play, some laughs, and some learning. We have a lot of time for conversations on a regular basis. No shortage of talking around here. We drink too much coffee, I bet. In my grange we make music and videos. There's probably a celebration around here every day. We bathe together and we work in teams. We don't keep track of our members. As long as they show up when they promise and with intention, they can count their own hours. People with only day roles can take a day or a week off and go hiking or surfing, or listen to music, or make their own music. Everyone's got a bed and food and can see a doctor when they're feeling bad. Each member belongs to their dachi, so nobody gets to become lonely by default. Here's something else I've noticed..."

She thought for a full minute. "OK. Here goes. People get assigned to their dachi. That might sound weird as a way to find close friends, but it really works. There can be a lot of friction in your dachi, but underneath it, these dozen folks learn to work together while doing chores in the grange. Over time, you get really close."

“That sounds kind of Pollyanna-ish, I know. But here's the real story. Having a bunch of close friends around helps each individual navigate their career: what they are doing with their life at large. We have grangers actively designing goods and software and 
fashioning ideas in the sciences, writing literature and poetry. We've got dancers and an amateur theater company. I'm losing my train of thought here. My point is that they approach these tasks as complete, open, caring individuals. My guess is they get a lot more practice being kind to other people in their dachi, people they never need to seduce or trick or impress. Grangers get better and better at being grangers over time. They become fantastic team members in their work. End of rant. Any thoughts?"

"It sounds really... nice."

"I see," she said. "Wow, you and Billy are just the same. What I described here is a wholesale, bottom-up revolution in personal growth and social cohesion. Spread this change across the globe-which is actually happening right now as I speak-and it's almost like introducing a new species of human. Only it's actually just releasing what was there all the time. We are becoming simply human again. But, since nobody had to fight a war or follow some planetary hero quest to achieve this; since the planet didn't have to suffer a Level 7 total collapse: you think it's just 'nice.' And, having said that, it is also really fucking nice."

Megan could hear Claire laughing in the background. Winston said, "Your Mom just told me I got my bias, and my ass, served to me on a plate. Let me now agree with you; profound culture change can flow quietly like a deep river, calm on top but surging underneath. No explosions required."

Megan said, "All right. Back to the economy. Where was I? Here goes. You can cash out your share any day and leave. People don't, but they could. Grangers are much more likely to move to a different grange in a foreign land to learn about life somewhere else. We all earn about the same amount, something this side of nothing; that's just to cover the transactions that do touch the outside world: taxes and loans and such. You don't need money inside the grange. Is your life in a rut? Take a break. You can learn a new skill, grab a shared car and go on walkabout, organize a frolic. None of these behaviors are bad for the neighborhood, or the planet."

"How do you keep growing?"

“We don't. In fact, we do with less each year. Living on less gives us more free time. We do intentionally increase our livelihood. There is a difference. We increase our ability to steward our commons. We increase the meaningfulness of our cultural practices in ways that make sharing more robust."

"How does that work?" 
"A couple really cool points here. We are approaching a zero-ownership society. In a grange you own nothing and everything. When your local society owns all of it-and you own a share in your society-you become free to demand what you need from the shared pool of goods, and from others. You can demand whatever you need at any time. Of course, this does not include personal relationships; they are still as awkward and consequential as ever. Demand sharing takes away all of the sources of existential fear, and it makes each day a source of joy, but it also needs a lot of cultural learning to work. So we increase our cultural activities and celebrate these when we can, which is regularly. To participate in this society, you also need to give away what you really value. You need to let go. And, you can't want everything. After a time you realize you don't want a lot of the crap you used to, and what you do want is here in abundance. That's also when you realize that generosity is the best source of genuine happiness."

"That sounds amazing. Is your grange exceptional, or is it just you?"

“Winston, you're flattering me. Don't let me discourage you. However, I think every grange works through these same cultural changes and builds new norms for itself. Since we share knowledge across the entire system, there's a lot of lateral learning around the planet."

"I need to go wrap my head around an economy that grows while shrinking its provisioning, that nourishes its members' well-being while it heals the planet, and that scales by example, experimenting and iterating. I have to say, it's an eye-opener."

"Winston, it's not a mystery. All you need to do is drop by any grange and you'll see all this in real life. You might want to join one while you're at it. Did you get what you needed?"

“One last question.”

"Shoot."

“What happens when a grange goes bankrupt or sells out to a corporation?”

"The first case happens occasionally. All the real property of a grange is put into a land trust, and all the IP rights are in a civic trust. So if the coop dies, the trusts can transfer the property to another coop, or the coop members can organize a new one. Selling out cannot happen at all, because of these same trusts. There's nothing to sell. And our liquid democracy governance prevents most internal power struggles. So, no faction can take over. Did I pass the test?" 
"Aces! Thanks Megan."

“What's next with your project?

"I've got to write this up and get it out to the Nerds. Then, your mom and I will be visiting a local grange to see about joining. You know, when we first got together on this, Jack challenged all of us to make something that would reboot the global economy. He said we need to invent "Game B." We couldn't figure out anything that might work at that scale, so we just made the Game..."

"Just?"

"OK. And the Game got a lot of people thinking, and then all this happened."

"So, you tell me, as an economist, will we succeed; this new economy?"

“That's pretty obvious.”

"Not to me."

"It already has."

\section{$\S \S \S$}

"Amitabh, Amitabh, it's me, Joseph. I have to introduce you to someone." Joseph leaned closer to the screen, whispering. "She insists. I'm sorry."

Joseph turned his head around. "Well? Go ahead. Speak to him."

Sarah squatted down and stared at the screen. "Is that him?"

"Just say what you have to say." Joseph turned to the screen. "This is my amma, Sarah."

"I am Amitabh." Joseph's guide's avatar put his hands together. "Now I know where Joseph got his good looks."

"None of that." Sarah said. "I'm here to tell you that Joseph can only play with you two hours a day. One hour in the morning, and one before bed. He has work to do and cannot spend all of his time..."

"Joseph!" Amitabh spoke. "Have you not been listening to your amma! What kind of a son are you?" 
"Look, you've made him angry," Joseph said to his mother. "I told you he wouldn't like..."

"I am not concerned about what he likes," Sarah said. "You have duties to this family."

"You see, Your amma is just trying to keep you from falling behind with your chores." Amitabh made another bow.

"But the Game..."

"Is not as important as your chores," Sarah said.

"I agree completely," Amitabh said. "I think together, Sarah and I can help you be more observant of your responsibilities. Thank you, Sarah, for bringing this to my attention."

“He's not a very bad boy..." Sarah tussled Joseph's hair lightly.

"Joseph is quite a Gamer, perhaps one of the best anywhere," Amitabh said.

“Well...” Joseph said.

"I would imagine that his skill must be in part genetic..."

“What are you getting at?” Sarah said.

"I would not be surprised if you might have some talent you have not explored."

“No!"

“Oh, yes.”

Sarah stood and walked away, shaking her head.

"Well done, Amitabh! She is gone."

“Bring her back."

"What?"

"There is someone she must meet. Go ahead, call her." Amitabh folded his arms and stood glowering.

“Amma!” Joseph spoke out loudly. “Please come here.”

"What is it?" She leaned over him, her neck scarf drooped over his eyes. 
He brushed aside the silk. "Amitabh wants you to meet someone."

The screen changed from Amitabh's room to the scene of a dry rutted road through a small village.

Sarah said, "My, that looks a lot like... no, it looks exactly like Chettipedu. There's your great auntie's house, just behind this one."

The door opening of the nearest hut was suddenly filled with the form of a woman of middle years, who bowed as she emerged under the low lintel. She was dressed in a baby blue salwar kameez that flowed over her ample figure. Once outside, she straightened up and made her greeting gesture. He face was open and broad. She wore no makeup but was adorned with the gold that signified her marriage.

"Sarah. You can call me Anjali. I am your guide. Oh my goodness! We are going to be such good friends."

“Get up, Joseph. Can’t you see she is talking with me...”

"Amma! That's not fair. I still have time."

“Do your work now, and you'll get your time later. Go on.”

Joseph stood and went to the door of the godown. His mother was rapt in conversation with her guide. Maybe this was a good thing. He figured she would find her own reasons to not put away the Computo.

\section{$\S \S \S$}

The group text message was short:

Nerd-ones, and Jack. Game B global economy prototype confirmed. Report follows. Prank is concluded. You can laugh now. Winston. 


\section{TWENTY-NINE}

Modeled from late gothic French citadels, the inner keep of Castalia's main castle building was a circular stone structure two hundred feet tall, with crenelated battlements and a bevy of swallow-tailed gonfalons aflutter at all times. The tower's roof was reserved for Grand Meisters, while its interior contained the council room of the Magisters. The top third of its curved stone wall was visible from almost anywhere in Castalia. So it was hard to not notice when a neon sign with ten-foot, magenta, bold comic-sans letters suddenly appeared: "Send Samantha Mooney Home." The home page of the website sendsamanthamooneyhome.com spelled out the threat to Castalia and the time remaining to respond. The digital clock was counting down from two hours.

Tiny Nguyen's cell phone woke him at four in the morning. He groped it from the floor next to his futon and managed to direct it to the ear that was not pressed into his pillow.

"Better be good," he said and listened. And listened. Then he spoke. "Wake the crew. Do not bother Scratchy. Unleash the hounds. We gather in the main conference room in fifteen minutes. There must be coffee."

"I understand," Thuc said. She had pulled the graveyard shift this week. Thuc kept her Castalia client open while she initiated the team's emergency cellphone tree. "Comic sans," she muttered as she typed. "Pure Evil. Who the hell is Samantha Mooney?"

\section{$\S \S \S$}

"Phase One is active." Narendra pointed to the screen of Dwayne's laptop computer. Narendra had advised against using any company hardware for this adventure. The top of the Castalia keep was emblazoned with their neon sign. "I told you Nam would deliver." Nam had provided Narendra with a Castalia login so they could monitor the attack.

“'Deliver' means I get a call from Samantha telling me where she is and that she's coming home," Dwayne said, holding up a cellphone. "When do we take down the site?" “At seven o'clock we strike." 
"Plenty of time for a bite. Say, I'm in the mood for some tandoori chicken, why don't you go and pick us up some take-out?"

"Me?" Narendra was about to mention that he was the technical lead of Western Trust, one of the largest financial firms on the planet.

"That's all right, I trust your taste. Oh, and get some of that fancy rice pillow shit too, and maybe something with lamb, not too spicy. And beers. We'll need a couple six packs. This is gonna be epic. I wish I was at the Doral Casino right now. Put this show on the big screen. Don't fuckin' stand there. Chop, chop!" He dismissed Narendra with a wave.

"Did you remember to move the fifty million dollars into your local bank account?" Narendra was more than happy this would be his last day at Western Trust. That billionaire asshole violated Wheaton's law every time he opened his mouth.

"I'll do that now. Nam's gotta keep Castalia down for twenty-four hours before we make that payment."

"You do not want Nam to be angry with you. Just look at what he can do!"

Narendra made for the door, cellphone in hand. He glanced back. Dwayne had pulled out his Pandora machine, his hand was on the bio scanner. Narendra punched the quick dial for the nearby Wildlands Restaurant.

“Hello Krishna, Prasad here. I need some take-out. Chicken tandoori, pilau rice, and lamb vindaloo, please. I'd like the lamb extra hot. That's right. Make the lamb Andhra hot. Don't skip on the jolokia. Like your paatti used to make."

\section{$\S \S \S$}

Nam Nguyen imagined the scene up in Sao Do. Tiny's team would have alerted the Castalia griefers, probably with a prize and some Shine for the first one to knock out the source of that sign. The sendsamanthamooneyhome.com site was hosted on the server of the Department of Art History at Columbia University. Nam had obfuscated this just enough so that the Sao Do crew would be able to store the message before any counter attack could be launched. He had inserted the neon sign into the Castalia site's inventory using Tiny's own login. 
As soon as they run their diagnostics, they'll know the sign was an inside job. That might delay them if they started to doubt one another. It might also alert them to expect StormVermin. No matter, they would still need to find and knock out Nam's servers, and then administer the corrective code.

Scratchy's StormVermin attack on the mesh used a counter-intuitive logic. Scratchy had originally coded the mesh to seal and repair any damage. Because the mesh's schema was fully rhizomatic, damaged parts could be isolated, repaired, and rebooted without any effect on the remainder of the mesh. His new virus code actually amplified the repair response until the entire mesh began to seal and reboot. The virus used the mesh against itself. Like an auto-immune disease, the stronger the mesh was, the more damage it caused itself. Within minutes, the mesh was busy repairing every node affected and incapable of accepting other instructions.

\section{$\S \S \S$}

Lieutenant Colonel Nancy Rankin was still at her desk at Fort Myers when the text came in. "Wonderboy is up to no good." Wonderboy was their handle for Nam Nguyen, perhaps the most accomplished hacker on the planet. The NSA's operations in Vietnam were not aggressive, but they had managed to keep tabs on Nam's apartment in Ho Chi Minh City. They had intel on a dozen schemes he had perpetrated in the last seven years, including the collapse of that giant Bitcoin bank in Japan and the massive worldwide airline ticket fraud a couple years back. It would take some effort and cash to rendition him out of Vietnam, but a bit of burglary would not be out of the question. "Wonderboy might lose his toys, if he is not careful," she texted back, authorizing her team to choose the first available opportunity to acquire Nam's laptop for analysis.

\section{$\S \S \S$}

"According to our server logs, you personally modded the Castalia code at four AM." Thuc said, looking across the conference table at Thuong Nguyen.

"That would mean I was coding in my sleep."

"I suspect you have a ghost alias," she said. "The login user name was tiny234. You created it..." She scrolled down a list. "Nine months ago. Several new admin users were created that month." 
"My user name is tiny23. Good catch. Our mole has been busy." He looked across the table. "Everybody write down their user name and pass these up. We will purge the admin list of any other names we find. Thuc will text you when the purge is done. When she does, log in and change your passwords."

“Thuc, go ahead and remove the mod to Castalia. What's the time remaining?" He took a large gulp from his cà phê sũa nóng.

"About an hour and a half."

He pointed across the table. "Give me your response scenarios for all known attacks on the services you monitor. We need a full back-up of the Castalia code and content. When that's done, put the whole site on read only, with a message about scheduled maintenance with an expected duration of two hours. And somebody get a line on this mystery person, what's her name?"

"Samantha Mooney."

"I'll need everything we can get on her situation. Let's wake the bear." He picked up his cell. "Call Scratchy," he said to it.

\section{$\S \S \S$}

Dwayne was in a sour mood by the time Narendra returned through security to the penthouse office.

"They took down the sign. Look." Dwayne pointed at the screen on his laptop. Sure enough, the Castalia keep was no longer emblazoned with a demand for Mooney's daughter. "It only lasted about forty fucking minutes."

"That is actually good news. It means we have made an impact with the core code developers." Narendra set all the food down on a credenza by the inner wall. "They're the ones who will become our reluctant allies after we destroy their mesh." Nam had been vague about how his virus would work. Instead of attacking through some service at the Castalia framework architecture level, Nam boasted he would simply wipe out their entire mesh. The core team would come begging for the antivirus code. That's when they would bargain for Mooney's child. 
Narendra had his own plans. His wife and child had already left the country. He was booked on a midnight flight for Paris. First he needed to get into Mooney's bank account. For that, he would require a few minutes alone with Mooney's personal laptop to avoid the two-step authentication.

\section{$\S \S \S$}

"Tell me about this Mooney girl," Scratchy said and his eyes drifted across the table to his team, most of whom were focused on their laptops, getting all their admin tools up and ready.

"Some time in August she went missing. Her father, who is an executive vice president at Western Trust..." Tiny pressed a key on his laptop and a photo of Samantha appeared on the wall, a selfie of her in a pink bikini on a tropical beach.

“Western Trust?” Scratchy’s eyebrows went up.

"It's this huge investment company..."

"What about the girl?"

"Her father put out a reward for half a million dollars. There is an internet site for information on her whereabouts. The site's server sits at a subsidiary company of an outfit called Zeus."

"I believe you've met one of our adversaries, or rather, two of them."

"I figure one of them is brother Nam." Tiny's face screwed up into a scowl.

Scratchy nodded.

“Nam always works alone,” Tiny said.

"You remember the dweeb at the Leg a few months back, the one with the dead-man switch and a vest full of virtual C4?"

"He was looking for a hacker."

“He was looking for Nam. He just didn't know it then." 
“Why would Western Trust come after Castalia? Don't they realize what the blowback will do to their web assets?"

"I'm guessing this is Mooney's private play. He probably bullied their internet security staff into helping him out. It's likely he bullied his daughter until she ran away. Now he wants her back. Somehow he connected up Castalia to her plans."

"We scraped the sendsamanthamooneyhome website before our griefers got to its server. There was a phone number in a comment in the HTML header. Samantha is supposed to call this number. Should we alert the Magisters?" Tiny said.

"She's probably a Gamer," Thuc said. "Gamers have been known to help each other escape from their parents. I'm betting she's a lot happier wherever she is."

"It would be good to locate this girl, just in case. Send a message to the Magister Council and copy the head of the GrangeMaster Guild. Tell them to find her, if they can, confirm her situation, and contact me in Junana if Castalia goes offline."

"Nam is dangerous," Tiny said. "He knows our defenses as well as we do." $\S \S \S$

“Now we just wait?" Mooney said. He looked over at Narendra, who was opening up the take-out containers and laying out plates and plastic forks on the credenza in the corner.

"Go to reddit.com," Narendra said over his shoulder. “That's R-E-D-D-I-T. Tell me what you see."

Mooney typed. A page of text appeared. "Hey look!” Right up top was a thumbnail of a screenshot of their sign. He clicked on this. The full image appeared and a list of comments. "They're talking about us." Mooney said. Most of the first comments used Wizard of Oz referents: “...and your little dog too;” “....and I’ll show her my flying monkey."

“Hey!” Mooney said. "These guys are creeps.”

"Welcome to the internet," Narendra said. "The food is ready." He popped a small cube of curried lamb into his mouth. The heat was blindingly intense. So tasty. 
Mooney came over and grabbed up a plate. "How is this gonna help us out?"

“The internet has a way of dissolving secrets," Narendra said. "As long as they don't know we want them to work for us, they will do it for free, and bring in all their friends to help."

He watched Mooney pile up some rice and tandoori on his plate and select out the biggest chunks of lamb from the paper container. Mooney grabbed a couple beers from the six-pack. He settled back at his desk. Narendra leaned against the credenza. He nibbled on a chunk of chicken.

Mooney cracked the top on a bottle of beer and took a great slug, then he forked the largest piece of lamb from his plate and popped this into his mouth. Narendra held his breath. It was actually possible that Mooney might need emergency medical attention. Mooney's hands grabbed at the desk, as though he were on a ship that was rolling in a heavy sea. His mouth gaped and choking noises rose from his lungs.

“Haaaaaaaa..." he hissed. His eyes were faucets, his face carmine.

"Haaaaattt." He spat out a mouthful of half chewed lamb, which splattered against his laptop's screen and onto the desktop. Then he grabbed up his beer and took a long swallow.

"Oh my goodness." Narendra knew that would only chase the heat down his throat. "You must have found a chili. Beer is no good for that. You need water, and plenty of it." Actually, water doesn't help at all, he knew.

"Fuck me." Dwayne stood up and clawed at his throat. His face was pouring sweat. He looked around and spied the door to his private bathroom. This prompted him to lurch in that direction.

As soon as the bathroom door closed, Narendra slipped over to the desk and opened a new tab on the browser. He keyed in the URL for Mooney's New York bank and clicked on the login button. From memory he typed in Mooney's user name and his new password. The screen changed and he was presented with some actions. He clicked on transfer funds and a new menu came up. He keyed in fifty million in the amount field and then pulled a card from his shirt pocket. This had the bank locator number and the account number for his new Cayman Island bank account. When he pressed "Complete," the computer asked for the answers to all three of Mooney's secret questions, which he typed in and pressed "Done." Then he closed the tab on the 
browser and walked back to the credenza. The only thing left to do was to wait for Nam to attack Castalia and then slip away in time for his flight.

\section{$\S \S \S$}

James's cell rang and he switched it to vibrate. He was still five minutes from his station in Brooklyn. After a minute the phone buzzed to announce a message. He put it to his ear.

“James. I can’t get to my data. Call me back, goddammit." The voice was agitated. James recognized it. Rebecca Simpkins was a new hire. She had spent four years collecting ancient pottery sample data across Asia.

James opened a browser on his phone. The department's website was down too. He kept telling them not to call him after work. He would get to their problem in the morning. He got off the train and joined the crowd climbing the stairs.

\section{$\S \S \S$}

At five-thirty AM the tree-lined side street in an old section of Ho Chi Minh City was empty and dark. Overhead, the sky was obscured by a cats-cradle of wires strung between and among the four-story buildings. The two agents, a male and a female, both in their thirties and athletically built, sat in their Noël sedan and watched the light streaming from a third floor window. Their packet sniffers, attached to the optical fiber cable overhead, fed a computer on the passenger's lap.

"What kind of a trace are we looking for?" she said.

"As soon as he tries to talk with anyone, we'll move in," he said. "We need to know who he's working for."

“Grab and go?” she said.

"I'll administer the goodnight shot. You get the laptop and any drives you can find. We'll put the goods on today's boat up-river. He'll wake up by this evening. I don't think he'll want to involve the authorities."

$\S \S \S$ 
Paul Reston spotted Chelsea Wilde out in the main room. She had just finished up taking the evening Dr. Lu class and was chatting with others as they cooled down. She turned and walked his way, headed for the public baths.

"Hi Chelsea," he said. "You got a minute?"

"Sure. What's up?"

"Step inside my office." He closed the door behind her. She sat down on the chair in front of his desk, toweling her hair.

“I'm pretty sure my dues are paid," she said.

He sat back in his chair. "How are you getting along? We don't see you in here much."

“That's because I'm mostly working over at the factory.”

"Is the work pleasant for you?"

"It really is, in a weird way. I thought I'd explore being a fashion designer, but when I saw the loom, I just couldn't do anything else. I'm working on my journeyman badge."

"You ever think about returning to California?"

"Maybe in a couple years, just for a visit. Why?"

“No reason. Just checking in. You know we are all really glad you decided to join us.” "Me too," Chelsea said.

“That's all. Enjoy your day!”

$\S \S \S$

“What do we know, people?” Scratchy looked around the room. Team members spoke up.

"The site is backed up, and a message appears saying it is undergoing maintenance."

"We have purged the admin user list and reset all passwords." 
“The Magisters and the Grange Master Guild have been notified.”

"All of our repair routines are ready."

Thuc and Tiny locked on to each other eyes. "We are ready... for every eventuality," Tiny said. Thuc nodded. Atmosfear was to remain their secret for now.

“Really?" Scratchy said. A grin crept onto his face. "I'd like to believe that." $\S \S \S$

"They must have given us someone else's order," Narendra said. "I'm sure I asked for mild spiciness. Try the chicken, it's quite tame."

Dwayne held up his hand, shaking his head. "Like a fucking briquet in my mouth," he said. "How long now?"

"Thirty seconds." A pop-up message warned them, "Castalia is in maintenance mode for two hours, no transactions are allowed. Sorry for the inconvenience."

“You see," Narendra continued. "They are preparing to be attacked."

Dwayne twisted open another beer. "What's it going to look like? Will there be explosions?"

“It will look like... That!" The screen image fractured into a complex series of diagonal lines and then the client application failed and quit. An operating system message came up, "The Application Castalia has failed unexpectedly. Do you want to report it?" Narendra tried to open the Castalia client again, it refused to run.

"That's all?"

Narendra opened a browser and tried to log into the web version. Even the custom 404 Error screen was broken. "Goodness me," he said.

The computer signaled an incoming Skype call. Dwayne grabbed up the mouse and clicked the Answer button. Nam's face appeared.

"Well Mooney, you've got them by the short ones now."

"I was expecting fireworks..." 
"Narendra, didn't you tell him how this works?"

Narendra said, "We are not exploding buildings in Castalia, we are breaking the entire software. Any significant down time for a site like Castalia begins to erode confidence and trust." This was from the talk he had given Mooney earlier in the day. Dwayne seemed to have a profound ignorance about anything digital.

"So, now what?" Dwayne said. He had been hoping to see some kind of carnage; avatars hacked to bits by flying dinosaurs, buildings melting from heat rays. For fifty huge ones, he figured they owed him rubble and corpses.

“Believe me, they are panicking. After they realize they cannot reboot, they'll be in touch. Keep your phone handy."

\section{$\S \S \S$}

The server logs scrolled across the screen. All of the team were scrambling to run diagnostics. A timer counted the seconds since the site failed.

"Something about this look familiar?" Tiny called out. They all watched the logs for a minute. "It's not an attack on our framework. They are attacking the mesh."

"Looks like Nam has reverse engineered StormVermin," Thuc said. They all turned to Scratchy.

"All right, let me try something." His fingers flew across the keyboard as he inserted his anti-virus code into the mesh. "We can only hope this works."

\section{$\S \S \S$}

"I've kept my end of the deal..." Nam said. He would extract the fifty million from Mooney, but the real payment would come from Sao Do. His new version of StormVermin differed enough from what he had gleaned from Scratchy's that only his own anti-viral code should work to bring the Castalia mesh back up. If he could attack Castalia, they had to know that Junana was vulnerable. The amount of Gitcoin that would convince him to give them his anti-viral code was still undetermined in his imagination. 
"And so you want to be paid," Dwayne said. Nam shrugged.

From behind Nam an arm clothed in black wrapped around his neck, choking him. The arm pulled Nam back out of his chair, revealing a torso and head sheathed in a black translucent stocking. A hand pressed a device like a small gun against Nam's right shoulder. He slumped backward out of camera range. Then a thumb grew large as a hand reached over from the side and gripped the top of the screen to pull this shut. The call died.

Dwayne and Narendra stared dumbly at the screen.

"What the fuck just happened?" Dwayne said.

"You want me to believe they're not working for you?" Narendra backed into the credenza. He stared at Mooney in a fugue of fear.

“What? No!” Dwayne realized he should have just paid Zeus to do exactly that.

"If Nam has been apprehended, then he cannot provide the antivirus code."

"Once I get Samantha back, who gives a shit."

"I have to go." Narendra started for the door. "You have put me into great danger. I quit! You hear me? I no longer work here!"

"Saves me the trouble of firing your ass." Dwayne watched Narendra quick-walk out the door and down the hallway. He picked up the telephone on his desk and punched a button. After a minute he spoke. “Good morning, Rita. Dr. Prasad resigned last night verbally, in my office. Have his desk cleaned out. Standard security routine. Notify his assistant. Personnel will need to open a search. I'll be flying back to Santa Barbara."

\section{$\S \S \S$}

They were all fixated on the scrolling logs as the global Castalia mesh computer ate itself across the planet.

"My old code won't stop it," Scratchy said. "The mesh is history."

Tiny read from his computer screen, "Our griefers have found the source of the virus. Their bots are taking down the server with a distributed denial of service attack." 
Scratchy turned to his team. "I need options, people." Around the table faces turned toward Thuc. Tiny nodded at her.

Thuc stood and walked up to the front of the room. "We call it Atmosfear." $\S \S \S$

James's cell chimed an incoming message. The bar he was in had a strict no-phone policy, so he pulled the phone only slightly from his pocket and glanced at the screen. This one was from the campus CIO. "Attacks ongoing to several campus servers. Initiate response and recovery ASAP." The woman next to him glowered his way as he shoved the phone back into his coat pocket.

"Work emergency," he said, and drained his beer.

“Then take it outside," she replied.

"Eat me," he mumbled, dropping some bills on the bar.

"What was that?" She made to stand up. He was already out the door.

\section{$\S \S \S$}

Back at his Gibralter Building townhouse condo, Dwayne poured himself a tall vodka and tonic, with just a splash of the latter. He kicked off his shoes, booted up his computer, and toggled the device display on the hundred-inch flat screen bolted to the wall. Narendra had saved the Castalia user info in a note for him on his phone. Dwayne found the website and tried to log in. The client was still broken. He felt the cell phone on which Samantha would call him in his coat pocket. His mind replayed the scene of Nam's apartment. What the fuck was that about? On a hunch he opened his bank account web service. The last transaction was from today: a fifty-million dollar withdrawal at around six o'clock that evening. "Motherfucker!” He grabbed his phone. "Call Prasad," he said to it.

"I have nothing to say to you, Mr. Mooney," Prasad said. "I no longer work for you. "Somehow that rat bastard Nam hacked my account and stole fifty mil." 
There was a pause. In the background Dwayne could hear, "Now boarding Group Five. Group Five for Paris, boarding at Gate 7."

"I told you he was a dangerous fellow," Prasad said.

"Are you in an airport?"

"I warned you he might pull some kind of double cross."

"Wait. Just an hour ago you were in my office..."

There was a blast of static from Dwayne's sound system. The giant computer display changed to a spotless white background. A young woman who could have been Mooney's housecleaner's daughter, only about ten times easier to look at, stepped into the middle of this space.

"Dwayne Mooney." She shook her finger in front of her.

"Prasad, I’ll call you back." Mooney set down the phone.

“Dwayne Mooney, I have been watching you. Now look what you've done.”

"What I've done is gotten myself robbed."

"Won't be the last time."

"Who the fuck are you?"

"You can call me retribution." Her hands went to her hips.

Mooney shut the lid on his laptop and the wall screen went black. He noticed his glass was empty, so he padded over to the kitchen and made another drink.

"Fuck my life!" he called out to the cosmos. Too much weird shit today. He checked his watch. The Knicks were playing in LA. The game was probably just starting. He could order a steak from the restaurant upstairs, and maybe have the doorman call an escort. This day deserved a happy ending.

He pushed the cable TV remote to activate the display on the wall screen. The game was in its first quarter. He had just settled back when there was another blast of static. The screen switched over to the same white background and the same young woman. 
"Now you are really pissing me off," she said. "Mooney, you are such a small minded man and a bad father. You have failed in your duties to your own daughter. You don't deserve to find her. I am Michelle. I speak for the Guild of Guides. Your attack on Castalia puts the whole Game at risk. I haven't decided what to do with you yet. Here's a little something to remember our first meeting."

The screen went blank for an instant and then the basketball game resumed. Dwayne puzzled at the mystery of what he had just seen. What kind of technology can do that? A muffled explosion from somewhere below him was followed by the electricity spiking and failing and the shrill wail of the fire alarm. The screen went black as did the room. He could smell the acrid scent of burning electronics. Emergency lights snapped on.

"What the hell?" He tried to call the front desk, but the intercom phone was dead. So he put on his shoes and headed for the stairs.

\section{THIRTY}

“Joseph, it is time I introduced you to Junana." Amitabh winked at him.

"Junana?"

"Junana is a digital world that was built for gamers. It allows them to discover new friends and places, to gather and celebrate, to meet for conversations. And it contains replicas of many of the world's largest cities and greatest natural wonders. All of these are available to you. From now on, when you exit the Game you can go to Junana. You have your own account with a profile of your accomplishments you can modify. There are some others on Junana who are quite young, like you. You might find conversations with them to be helpful."

“Replicas of cities?”

"Built up from contributed images and crowdsourced programming over the past decade." 
"Not just in India?"

"World wide." Amitabh spread his arms out wide. "Where in the world do you want to go first?"

“That's easy. London.”

"London. Any particular spot?"

“Pickledilly Circus.” Joseph liked the idea of pickle that was also a circus.

"Picadilly it is, guv'nor." The screen went dark and then blossomed with bright sun and the crush of traffic. Joseph's avatar was standing on a pedestrian island in the midst of intersecting roadways. Caravans of giant red buses cruised by. No pickles in sight. The buildings boasted video walls advertising companies and fashions. Joseph heard Amitabh's voice offer instructions.

"You can speak with anyone who has a green halo. You toggle your own halo display here." A menu item blinked. "You can show or hide your Game status and Shine like this." Another menu item blinked. "Buildings with open doors can be entered. You can use voice commands to navigate across town. Just mention your destination."

"Take me to the British Museum," Joseph said. His father had once told him that the British were the biggest thieves on the planet, and they showed off their stolen colonial loot at this museum.

Joseph's avatar accelerated along the sidewalk moving between and through others, and then cars and buses, in a blur of color and sound until it found itself facing the colonnaded front of the Museum. He moved his avatar forward, up the steps and into the edifice.

“This is quite outstanding!” he said. "How long do I have?”

“About twenty minutes until I shut down your Computo."

“But I can come back?”

“Whenever you've been good on the Game."

Joseph's jaw dropped. "Any time?"

"The world is yours." 


\section{$\S \S \S$}

Scratchy was as proud as a grandfather at the birth of his first grandchild. The Sao Do Castalia crew's response showed massive ingenuity. The Atmosfear hosting framework was ready to start delivering Castalia content from cloud servers on four continents, and the interaction latency would hardly be noticeable.

"I don't think Nam expected this," Scratchy said. "Well played, everyone!”

The room broke out in cheers and applause.

"You're not sad we couldn't save the mesh?" Thuc said.

"Patchwork piece of shit. Glad to have it behind me."

"We're still running the Game on one," Tiny said. "I wonder if Michelle paid any notice to this action."

\section{$\S \S \S$}

As far as James could tell, the griefers started by attacking his Art History servers, and then moved on to Anthropology, and then somehow got into the campus web servers and took down the University's main site, and with some vengeance. They continued to exploit shared services that linked machines across the campus. Their code hopped between server farms and injected requests that scrambled data bases and fried memory chips. The campus CIO was talking about going dark, of simply shutting everything down. His last email had spoke of more than a thousand simultaneous attacks on their campus-wide servers. He requested everybody to be on campus by six am. As unreasonable as James considered that request, it seemed more like a command. James set the alarm on his phone for five AM.

\section{$\S \S \S$}

Thirty flights of stairs gives a man some time for reflection. It sure didn't look like Samantha would be calling him after all. It also looked like Nam was in deep shit with the wrong people. Hell, Nam might not even be alive. If Nam didn't rip him off, that 
would point to Prasad. Dwayne didn't like that idea. You expect better from an employee. Besides, Prasad didn't strike Mooney as the larcenous type. In any case Dwayne was down fifty huge with nothing to show for it. And he'd probably have to pay income tax on that too, unless he "borrowed" another half a billion dollars from his offshore company at ten-percent interest. "Fuck me, fuck me, fuck me," he chanted as he skipped down the stairs. The fire alarm was even louder in the stairwell.

"I beg your pardon!" An elderly woman cringed against the wall as he passed her, nearly knocking her down.

“Don't hog the stairwell, sister,” Dwayne said.

\section{$\S \S \S$}

Chelsea lay back on her futon reading The Dreadful Lemon Sky. Garret had introduced her to Travis McGee stories. He had them all in paperback. The prose was spare and fine, but reading about Fort Lauderdale made her long for California or Kona. For some reason her grange manager had asked her if she wanted to go home. What she really wanted was someone to really talk with. She had reflected on the irony of her current situation. Since a child she had been superficial as a pose. Now that she had things to confess, superficiality was her prison. It was a cold drizzly Sunday at the ass end of November. Yesterday, the Rat dachi had narrowly lost in the regional ultimate semi-finals.

Thanksgiving at the gumi house had been spectacular. Three housemates, including Chelsea's new roomie, Angela, had gone back to their families, but the rest made it a full day of cooking and music and games and feasting and more music and a taste of weed, which was new for Chelsea. She didn't feel it much, but she thinks she might have eaten an entire pumpkin pie. Even though Christmas was officially coming, none of her dachi sisters and no one in her gumi house ever seemed to go Christmas shopping, not real shopping, where you target a dozen stores over several hours, and end up with armloads of bags filled with presents. In Santa Barbara, Samantha had spent nearly twenty hours a week shopping, and more when Sheryl took her down to Century City or Beverly Hills.

Mostly people made things to give away on the holidays. Chelsea hadn't yet picked up any crafter badges, but Holly had promised they could make up a big bunch of holiday cookies this afternoon that would serve Chelsea's gifting needs. 
Chelsea was back in high school in the Game. Moses explained to her that, while she could also attend classes at the college, it would be good to get through the high school curriculum first.

“By the New Year we can have you through your classes, just like that!" Moses snapped both fingers. "In the meanwhile, you can concentrate on Level Three."

She had been pacing out her Fantasy adventures, waiting until the weekend when the house was emptied out. She had picked up her own VR headset when Amber moved away. She let Moses choose: "find me something amazing!" And he always did. Moses said that soon as she got through high school they'd be moving on to Sex 101. She told him by that time she might be ready for 202 .

\section{$\S \S \S$}

Holly was being patient and kind.

"You cream the butter and sugar together, like this." Holly used a wooden spoon to stir the mix. "You try now." She handed the spoon to Chelsea.

Holly's master kitchen took up the former kitchen, pantry, and dining room of an old Asheville mansion that the mura had picked up at auction. The room was bright and warm and friendly. Like Holly.

Chelsea had brought enough ingredients for twenty dozen shortbread cookies. Holly provided the pans, her skill, and the gift of her time on this Sunday afternoon. Her ovens ran on hydrogen generated from the solar panels on the roof. Holly seemed to run on pure kindness.

While the cookies baked, Chelsea thought back on the night she helped that young girl escape. Her service had somehow paid a debt she had shouldered without knowing. Chelsea had never felt worthy of the efforts so very many people had made to help her escape. The scar from her father's ring had long disappeared from her cheek. The worry she carried for making such a monumental case from a momentary event had dissolved in the tears she shed for her sister in need. She realized that her own desire to escape was as vital and urgent as that of any other child with parents unfit for that title. She had earned her right to live free.

\section{$\S \S \S$}


Nam Nguyen woke up on his back on the floor of his small flat. He had a blinding headache, probably from their drugs, and also from the knock he took when they let his head fall back. He wasn't bound. For some minutes he didn't move but only listened. They were gone. By the angle of light on the floor it was late afternoon. He sat up and looked around. They had cleaned him out. Everything with plug or a cable was missing. All the drawers had been emptied onto the floor. They had been very thorough. He figured he had underestimated Mooney. The bastard had waited just long enough for Nam to set everything in motion. This is how Mooney paid him. Nam pounded his fist on the floor.

\section{$\S \S \S$}

57th Street was crowded with displaced Gibralter Building residents waiting for the all clear to go back into the building. Billionaires in designer t-shirts and Italian sweatpants huddled in small groups. Fire trucks idled on the street. Mooney wandered closer to the doorman, who was talking with the restaurant's head waiter.

"Must have been a freak electrical surge on the circuits that feed the building's cable and telecom networks. That's what started the fire. Then the fire screwed up the main electrical panel, which blacked out the building. The firemen say they've never seen anything like that except for a direct lightning strike. I don't know when we're getting back in."

Mooney made a quick decision and set out walking down the street. The Four Seasons was likely to have a suite available for the night. All he wanted was for this day to be over.

\section{$\S \S \S$}

Narendra Prasad sat in the center seat of the middle isle of the coach section of a 767. He was far too excited to sleep. From a plastic bag at his feet he pulled the take-out box of lamb vindaloo he had snatched on his way out of Mooney's office. He opened this box on his seat table. A small boy next to him looked at it and then up at him.

"That smells good," he said. 
"Smells just like five crore dollars," Narendra said.

\section{$\S \S \S$}

Scratchy opened the door in the Room that simulated the front door of Betsy's house in New Orleans. He stepped out on the front porch. Betsy spent some minutes most days standing her avatar here. What Scratchy saw was a high resolution real-time feed from a gang of three cameras mounted just above the actual door. It was night in Louisiana. Some light filtered through drawn curtains in the houses across the street. Cars rumbled past. A skateboarder clattered by. A Junana message from the grand master of the Grange Masters Guild appeared in his chat window. "Mooney girl is happy and healthy and has no desire to return home." Scratchy responded. "Understood." Her daddy's plan to get her back was brilliant in its own way. It also betrayed the mindset of a bully. And it must have cost him a fortune. She is well off being far away from poppa, he figured. Scratchy ducked back into the Room and shut the door.

Winston and Desi popped in almost simultaneously.

"Shall we wait for Itchy?" Desi asked.

"I'll fill him in later if he doesn't show," Scratchy said.

Scratchy went through the entire attack on Castalia in detail.

"The mesh is still down?" Desi said.

"We just redirected everyone's software clients to the new cloud-hosted content. We have no plans to fix the mesh. Nam broke it, now he owns it."

"What are the takeaways?" Winston asked.

"I'm impressed with the initial benchmarks on Atmosfear. I want to see hundreds of copies of Castalia across the planet," Scratchy said. "With some tweaks, this platform can handle Junana and the Game, when it comes to that."

"If it comes to that," Desi said.

"I'm sure Nam will be looking for a buyer. It's only a matter of time. He'll offer it back to us for a price we can't afford and then sell it to the fucking NSA." 
"Hi everyone." Itchy popped in. "I had to read another story to little Mikey. I miss anything?"

“Castalia's back up," Desi said. "But its mesh is toast."

“How many granges have uploaded the Game backup using Jubal?” Winston said.

"Nearly three hundred so far." Scratchy said.

“Where is Simon?” Desi said.

"I pinged him too," Scratchy said.

The real question is: where is Michelle?" Itchy said.

"Let me ask someone who might know," Scratchy said. He looked at the note and keyed in the phone number.

\section{$\S \S \S$}

Dwayne had just dismissed the perky young blonde thing that his escort service had sent up. She had managed to get him off only twice. She was working on him again when he realized how tired he was. The whole day had been one long disappointment. And when he remembered that digital bimbo, Michelle, he just went limp. So he sent the blonde away, scolding her for her lack of talent.

"I've had MILFs that could get me harder than you," he said, smacking her ass with the door when he shut it behind her.

His phone started ringing on the desk by the sofa. Not his normal phone, this was the phone Samantha would call. He wrapped the hotel robe around him and grabbed it up.

“Sam?”

“Dwayne?” It was a male voice. "You old goat fucker you, how are you doing?"

"You're not Samantha."

"I'm not a lot of people. Listen to me for a minute. Did you have a surprise visit this evening?"

"Surprise?" 
"Possibly somewhat explosive?"

"You mean Michelle."

"Michelle Valentine Smith. One and only."

"Who are you?"

"Call me the ghost of Christmas future. I'm here to tell you just how fucked you will be."

"Do you have Samantha?"

"Dwayne, nobody has Samantha. We have contacted her. She is happy and healthy and damn lucky to be as far away from you as she is. No, it's Michelle that you, and definitely your buddy Nam, will need to focus on."

“Nam just stole fifty million from me. He's no buddy of mine. At least he broke their software..."

“Look again, bozo.”

Dwayne opened up his laptop. This was still running the client for Castalia. The towering castle walls mocked him. “...goddamn! What a fucking loser Nam turned out to be."

"You should know. Actually, your plan would have worked. At least we would have needed to consider asking your daughter to call you up."

"Instead, I've had the pleasure of your company. I've got people who can trace this call..."

"What I really wanted to do was thank you."

“Thank me? Just wait, buddy...”

"Your attack on Castalia has set in motion the process that will release the Game into the world in a manner that should protect it for decades. We couldn't have done this without your help. I can now predict that the Game will become superversatile within years, maybe months. That doesn't mean you can escape Michelle's revenge. You can't hide from her." 
"What the fuck!" Dwayne raced over to the windows and quickly closed the curtains.

"Revenge..."

"'Fraid so."

"I’ve got more security than most Presidents."

"Must be a comfort to you. Still, she can find you."

"She fried the internet for my whole building."

"Did she? She didn't happen to say anything that might clue you into her future intentions? I'm only asking because sometimes her collateral damage can be spectacular."

"What the hell is she?"

"Dwayne, she's a second-order artifact from an artificial intelligence spawned by the self-learning programming of a billion Game guides over the past decade. That jackass President Stone and his cronies let her out into the internet. I have a feeling you might be seeing her again soon enough?"

"What the hell does she want?"

"I have no idea what she'll try. For me, that's the exciting part. For you, well... Michelle is quite full of her little surprises. Ask the Chinese military. Or maybe don't. They are still looking for whoever did it to them..."

“Did what? I haven't done shit."

“Don't say that, Dwayne. I'm sure you're completely full of shit...”

Dwayne pulled the phone away from his ear.

"Dwayne?" the voice said. "You still there?"

“Go fuck yourself." Dwayne ended the call.

$\S \S \S$

Back in the room, Scratchy told them what they dreaded the most. "She is back and she's pissed." 
Simon Bishop’s avatar popped in. "Got your call."

"Simon!" Desi said. "We were wondering if the attack on Castalia might bring you in from the cold."

"What happened?"

Itchy gave him the short version.

Simon walked around the dining table and turned to face them. "Papa Nerds, I salute you!" His avatar did a low bow.

"Don't be too happy," Scratchy told him about Michelle.

"Michelle and I talk a lot," Simon said. "She keeps me a couple steps ahead of the constables."

"Then you'll tell us when she decides that the Earth would be better off without homo sapiens," Desi said.

"She's known that for a decade," Simon said. "I keep telling her that we're about to surprise her. She loves surprises."

"You got any in mind?" Scratchy said.

“Has Desi told you about Discourse Repair?" Simon said. "We have plans to implement this in more than sixty nations."

"I knew there was something I was going to mention," Desi said. "What was your plan for Dr. O’Hara again?"

"Senator from California," Simon said.

"I will serve no state that would have me as their representative," Scratchy said.

"Then just settle back and watch," Simon said. "You might want to put a seatbelt on your Cordobalounger. It's going to be quite the ride."

"You really think the Game mesh will fail?" Itchy said. Scratchy had lit the candles on the table. Itchy stepped closer to inspect them. The flames looked slightly pixelated. He would need to upgrade their algorithm. Their reflection off the veneer of the table was excellent. 
"Nam could release his own StormVermin virus any time. Whoever buys it would do so for only one purpose: to destroy the Game." Scratchy stood his avatar beside Itchy.

"They tried that before," Desi walked up and put his avatar's arm around Itchy's other shoulder. A moth appeared from a dark corner of the Room and was circling the flame. "You do good work, my friend."

Winston stepped forward and put both hands on the table. "Guess what? Even if they destroy the Game and Castalia and Junana, this new Game B economy has legs. It's nowhere and everywhere, and they can't stop it. This time they'll need to deal with the Game nation."

“Game nation,” Simon said. “A nation without borders or capitals.

“Without a country,” Desi said.

“With no religion,” Itchy said.

"With no possessions," Winston said.

Scratchy said, "Imagine that."

\section{THE END}

of Junana: Game B Nation...

and

THE BEGINNING of Junana: Game B State.

\section{AFTERSTUFF}

Disclaimer: Junana: Game B Nation is a work of fiction. Any similarity or likeness to any events, locations, institutions, themes, persons, living or deceased, characters, and plot is purely coincidental. 
PHOTO BY: Kris Krug, used with permission

\section{Praise for Junana:}

"In a society quickly shifting into an age of hyper-connectivity, Junana is a timely read. The narrative is as fast-paced and complex as our supermodern, technosocial lives. Caron creates a world so vivid and omniscient that one wonders if Caron is simply reporting on something that is already happening. Caron effortlessly handles multiple perspectives, social classes and age groups. Junana should appeal to educators, marketers, programmers and anyone who is a critical thinker looking for something unique and rich for their cranium to bite into. Junana is an important work that provides a lens with which to greater understand the rapid change we're currently experiencing." Amber Case, cyborg anthropologist

"Junana was a fabulous book. It was part Snow Crash, part Neuromancer part modern society and the implications of our social networking. It captures what might happen if we had an accelerated learning system, who would be challenged by the notion, who would build on the notion. The is a great story and many deep issues that leave you reflecting about social networking, gaming, learning and the world that we live in or what it might be........." Dave Toole, CEO Outhink Media, Inc.

"Highly recommended!...The very interesting premise is thoughtfully worked out. A bit of techno-speak sprinkled here and there lends verisimilitude, but non-techies can ignore it in favor of the story." Jeff deLaBeaujardiere, NOAA geek and musician

"Junana is a pilgrimage through a not too distant possible future where online gaming and education become symbionts. An intelligent and thought provoking read. I can't recommend this book strongly enough. In 10 years I hope it will be read as a documentary!" Nodnarb on Amazon.

"This is the most positive possible future I've seen so far. Gaming over the web becomes a tool to accelerate learning. This could happen." David Arctur U. of Texas 